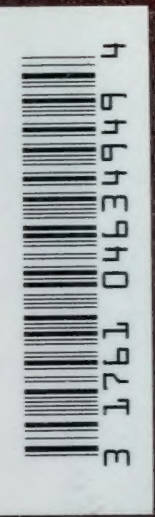


Ap und

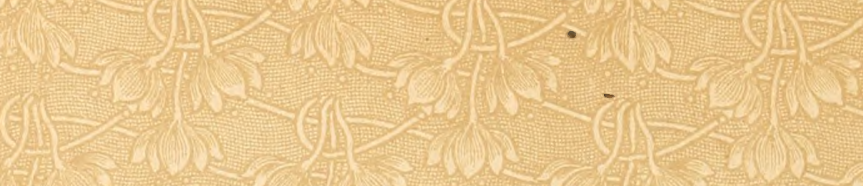

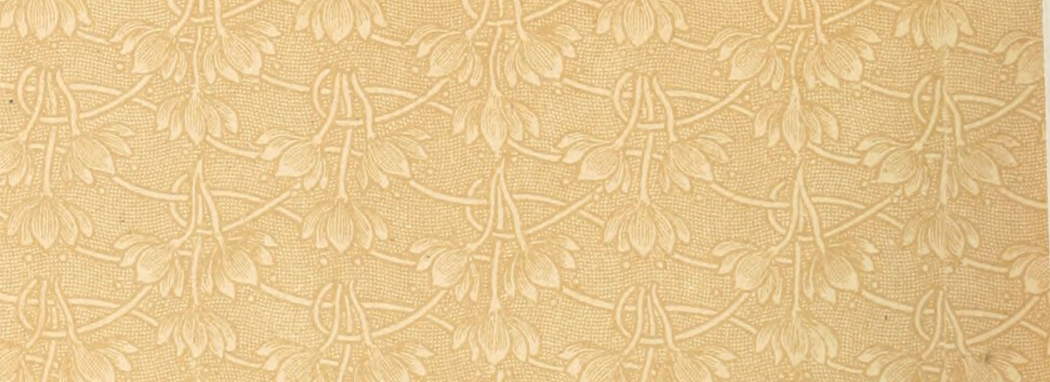

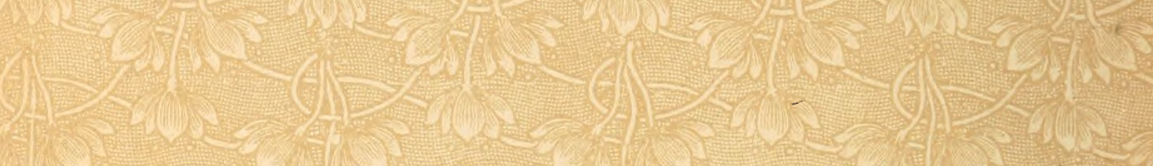
(A) Ap

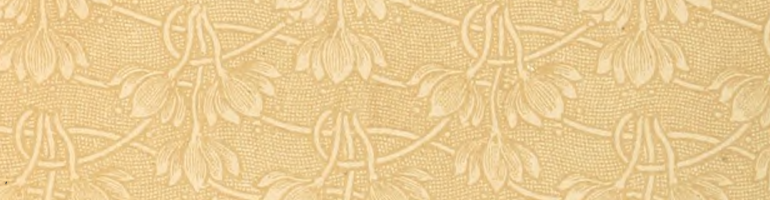
$\left(0, \frac{1}{2}\right.$ Aps $(x-y)=$

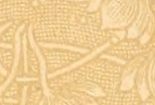

(9)

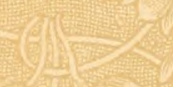

Ap

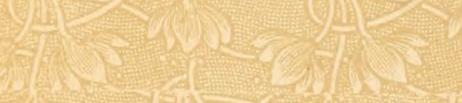
(A) $>$ (

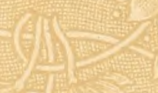

然

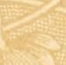

9.

g्a

(9)

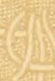

$(6)=12)$

$(\pi)=12$

90100

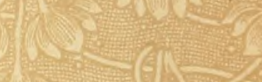

Q

12

4

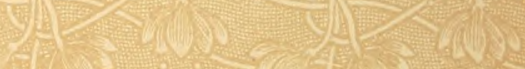




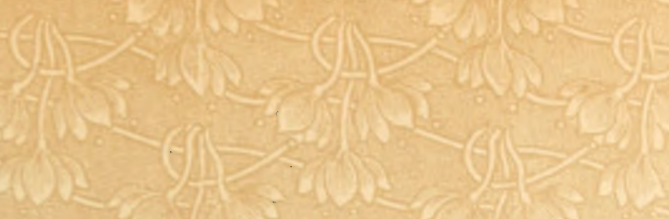
(2)
(4)
(c) $P$ (1)

a

2.

$\log ^{2}-\operatorname{los}^{2}$

(a)

(

(5)

ge

Apin

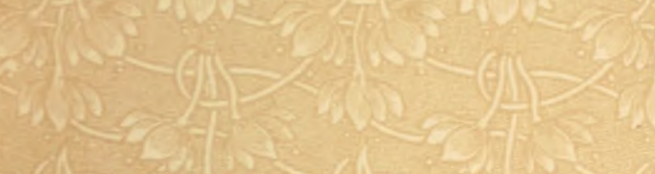

Yete

$x+4>2$

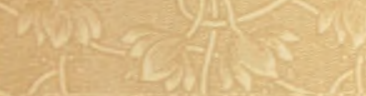

(9)

(a) $107(3)=$

and $x=0$

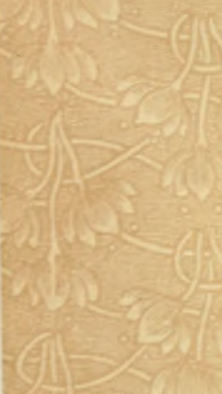

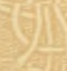

$-(9)$

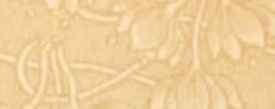

(6)

(6)

$(2,5)$

$3 \frac{11}{8}$

(6) $-207(5)$

(9)

(9)

(9) 19

8

$2)^{2}(x+2)$

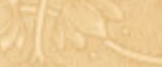

Y)

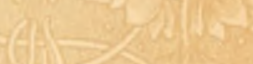

(9)

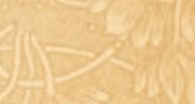

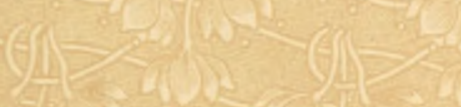

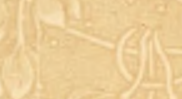

(6) $\rightarrow$

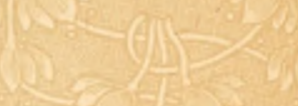

(6)

(9)

(9)

Dherie

y

Q)

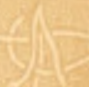

$29(2)$

$(9)=2$

(9)

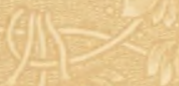

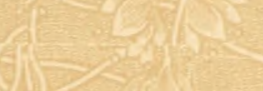

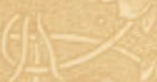

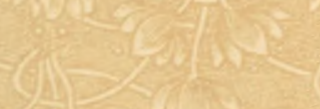

$=(6)$

axy

(6)

$\left(\frac{6}{6}\right)$

(9)

(9)

(6)

(6) $=$

(6) 

TERMÉSZETTUDOMANYI

KÖNYVKIADÓ-VÁLLALAT.

MEGINDULT 1872-BEN.

LXX. KÖTET. 
TERMÉSZETTUDOMÁNYI

KÖNYVKIADÓ-VÁLLALAT.

A M. TUD. AKADÉMIA SEGITKEZÉSÉVEL

KIADJA

A K. M. TERMÉSZETTUdOMÁNYI TÁRSULAT.

LXX.

HERMAN,

A MAGYAR NÉP ARCZA

ÉS JELLEME.

4

A XI. (1902-1904. ÉVI) CZIKLUS

ELSÓ KÖTETE

A KÖNYVKIADÓ-VÁLLALAT ALAiRÓI SzÁMÁRA. 
A

\section{MAGYAR NÉP ARCZA ÉS \\ JELLEME.}

IRTA

HERMAN OTTÓ.

TIZENEGY TÁBLÁVAL ÉS NEGYVENÖT SZÖVEGRAIZZAL.

\section{BUDAPEST}

KIADJA A K. M. TERMÉSZETTUDOMANYI TÁRSULAT 

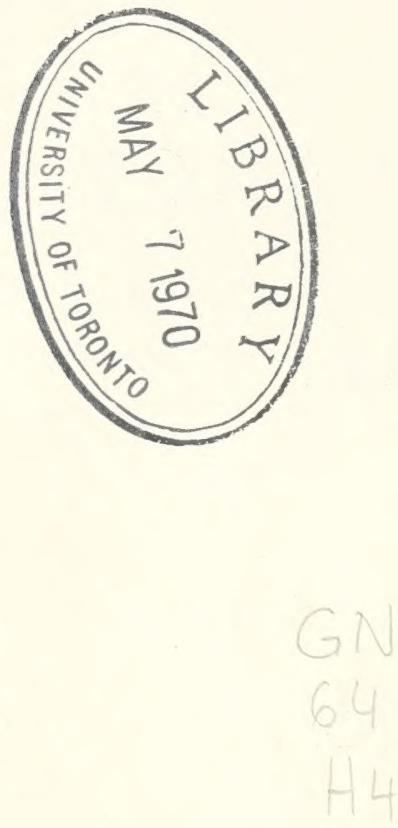


\section{ELÖLJÁRÓ SZÓ.}

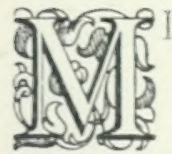

INDAZOK, a kik a magyarságnak az elmult XIX-dik század utolsó harmadrészében folytatott küzdelmét és irányzatait már érett észszel figyelemmel kisérhették, és még inkább azok, a kik a magyar nemzet közéletében munkás részt vettek, igen jól tudják, hogy annak a századnak utolsó harmada jól-rosszul, de mindig tudatosan annak volt szentelve, hogy közéletünk egész mezején, megfeszített erôvel, a végsőig menö áldozattal is ,századok mulasztásait pótoljuk".

A haladásnak mintegy fokméröi, a különbözö szakgyúléseken, utóbb kongresszusokon kívül, ezek között nemzetközieken is, különösen az általánosabb jellegú kiállitások voltak, a melyeknek hol ipari, hol gazdasági keretei közé mind eróteljesebben nyomult be a múvelödés, majd a tudomány és múvészet szervezete.

Jól tudjuk azonban azt is, hogy itthon begyakorlódva és nekierösödve, a müvelt nyugaton nem tudtuk, mert csakugyan nem is bírtuk a kiállításokon mint nemzet és állam teljes önállóságunkat kifejteni, ezt föltétlenül bebizonyítani ; igy minden elismerés, a mely mégis jutott, az ismeretes „érdekes népség“ mellékizével bírt.

De azért nem lankadtunk! 
S a nagy erófeszítés, melynek végczélja mindenkor és tudatosan a magyar nemzet elismertetése, befogadása az európai múvelt népcsaládok közé volt, egyre csakugyan megtanított, arra, a mi nem tartozott a régi magyarság ősi és jellemző erényei közé : megtanított egyesült eróvel, tervszerüen dolgozni, a munkát idejekorán megkezdeni és határidöre be is végezni.

Ennek a valóban nagy haladásnak mintegy próbatétele, a mint tudjuk, a magyar állam fennállásának ezredéves fordulóján rendezett, valóban nemzeti kiállítás volt, melynek keretébe külön és a legtávolabbi multba visszaérő történelmi osztálya tartozott.

$\mathrm{A} z$ a szerencsés gondolat, hogy a kiállítás e részének megítélésére Európa nyugatának legkiválóbb szakférfiai kérettek föl, ezek a meghivást elfogadták és a történelmi részről fényes, elismerő és komoly véleményt adtak, ez a legközelebbi jövő alakulására döntö hatású volt.

Senki sem tagadhatja, hogy az 1896-iki nagy próbatét és a történelmi részszel elért nagy siker szülte azt az elhatározást, hogy a magyar nemzet a XIX-ik század nagy zárójelenetében, az 1900-iki nemzetközi világkiállításon Párisban megjelenve, ott bármily anyagi áldozat árán is, mint önálló nemzet és állam mutatkozzék be.

Nem tisztem, de nem is tartozik erre a helyre e vállalkozás tervezetéról és végrehajtásáról részletes véleményt mondani és éppen ezért itt csak azt érintem, a mi némileg e könyvvel is kapcsolatos.

Ismeretes tény az, hogy Magyarország a rengeteg tárlat minden tagozatában külön és önállóan rendezte be osztályait, és hogy szervezetének betetőzése, megkoronázása a magyar történelmi pavillonban csúcso- 
sodott ki, mely az örök tényü . Rue des Sations" derehín, at angol parillon tös\%onnszédsálgaiban foglalt helyet és liöztionelmet lieltett.

A villalliozátsnak éppen türténeti rés\%e volt merés\%ségében példa nélküil álló: mert a maşarok nem vittek ki másolatoliat, hanem kivitték at meus sem becsülhetö értékü nemzeti, türténeti kinesek eredetijét! Elritték ezeliet oly helye, at hol igaz, összejött mindar, at mi nagy, diesö és nemes: de a\% is, a mi bün. És e\% utóbbi azon a világallialmon ugyancsak felgraulekezett!

A magrar kiállitás legföbb intézöit esak akkor fogta el a félelem, a mikor a küilföld legilletékesebb tërfiai azt kérdezték: hogyan merhették Önök ezeket a kineseliet annvi reszedelemnek kitenni?

Ám ez a merés\%ség, a mely alapjában véve abban gyökerezett, hogy a valódival küzdjük ki az elismertetést, éppen az utóbbi oknál fogra bizonyoult szuiliségesnek.

Hiába! korunk társadalma mégo a lewhívebb másolattal szemben is tartózkodó - és ott, a hol elismertetésról van szó, csupán az credetinck his\%.

És bebizonyult az is, hogy hiába valo minden okoskodás, mert bizonyos az, hogy a hol a világ itélöszéke elótt egy adott nemzet elismertetése kerül szóba, ott nem kevés jelesének, esetleg a lánécésznek fénye és bármily ragyogása, hanem az egrész történeti fejlüdés a döntö.

Az ember kiválóságra, a lángéš, minden idöben és mindenütt elsösorban erryéni tulajdonsásge, melynek fénye, egyéntöl eredre, erre sugál\%ik vissza; a nemzetre, a melynek liebeléböl lielt, kö\%vetet, viss\%atrerö́ö́s és azért hiderg fény áradhat csupán. Maşára 
az adott nemzet egészére csak a történelmi fejlódés

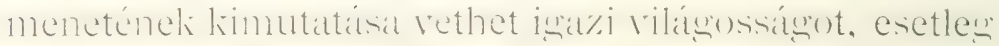
valódi fényt.

Es éppen azért gyakorolta az 1900-iki világkiállításon, a legnagyobb, döntö hatást az, a mit az ú. n. „Petit Palais“ egybefoglalt, a mi a nyilvános, állami

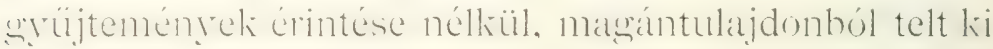
és annak a nagy franczia nemzetnek egr ezredérre ter-

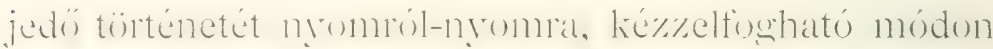
magyarázta és bizonyította; és bizonyította a nemzet kulturális fejlëdésénel fünyes menetét. s\%ervesen összefüiggö egymásutánban.

A francziák evvel a ragyogó kiállítással alapjában ugyanazt tették, a mit tettek a magyarok történelmi

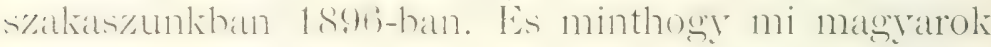
1900-ban Párisban is, éppen mint a francziák, összefüggö sorozatban, kézzelfoghatóan és a valódiság alapján bemutattuk történeti fejö́désünk rendjét és menetét, ebben a döntö súlyú történeti alapot: ki is vívtuk az elismertetést.

De máskülönben is rajta volt a magyarság, hogy jóval és valódival vegyen részt az 1900-dik évi világversenyen; különösen avval is, a mi a magyar múvelödés fokit és iranratit bizonýthattat. E törekrés keretébe tartozott az az élénk részvétel is, a melyet Magyar-

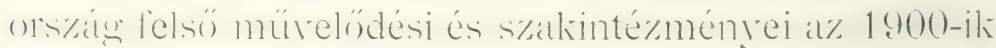
évi világrerseny allialmátral rendezett kongress\%usoli töméntelenségében a maguk részére kivettek.

Ezekre az „akkori világkongresszusokra" nézre a tudományos körök közvéleménye az, hogy tárgya-

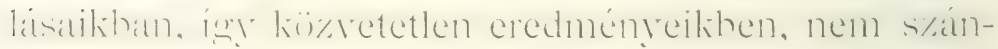
tottak nagyon mélyen, a mi különben érthetö is volt. Maga a világváros ezernyi-ezer vonzópont- 
Jitval. howzit at libillitis s\%inte elloürölö fünye, nem

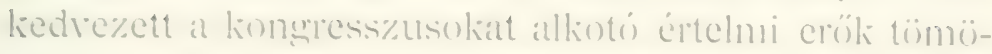
riilésének, elmélyedésének; és aliadályoztat e\%t a nyilrámlalú soliatmanliolás természetes követhezménye is.

Azonban mindiz, a mit ergesceli ús intézménycli e kongresszusokrat a világy minden tájáról liészen enverbehordtak, livált a tudományos irodalom képében. minde\% kineset jelentett.

Es ebben a tekintetben minket matryarokit a konwresszusok málr ismerni kezdenek, mert a kormámyzat áldozatliészsége, mely az elismertetésért való küizdelemböl folyó tudatos cselekrés. lehetöré tes\%i, hogy müielödési intézményeink igen értékes kiadványoliat ajánlhatssanak fel.

Az 1900-ik éri nagy allialomáa sem ment el at magyarság üres kézzel. És a mennyiben a magyarok szereplését áttekinthetem, a kongresszusoknak felajánlott tudományos irodalom nagyon értékes volt: mindenki igyeliezett, hogy a legjobbat nyújtsa, mert mindenki tudta, hogy a rilágkongresszusok asztalára letett kiadrány a világ legilletékesebb köreiben fos elterjedni és meg fogja alkotni a magyarság szellemi tartalmának mértékét, ebben értékét is.

llyen körülmények lïzött igen helyes volt az a vállalkozás, mely azon a világalkalmon, a hol a malgyarság a leghomolvabb alakban vette föl a harczot elismertetéséért, azon rolt, hogy ezt a masyarságot tudományos értékü arczképeliben, mint emberfajt is bemutassa; még pedig a legilletékesebb testületnek, a Párisban összeült XII-ik nemzetközi anthropolongiai és régészeti világkongress\%usnak.

Az illetó kiadrány fö́czime szerint: „Maggyá tipusok" - .Masyarische Typen" 1900., szijleg 
szerint magrar és német; kiadatott pedig a magyar Királyi kïzolitatásügyi kormányzat támogatásával, mint a magyar Nemzeti Múzeum ethnografiai osztályának hivatalos írata.

E\% a két utóbbi körülmény nagy súlyt kölcsönöz a kiadványnak és ennek rendén az e kiadványban közrebocsátott arczképek ez idó szerint mint hiteles. magrar tipusok szerepelnek az anthropologia ismeretkörében: nemcsak, hanem mintegy hitelesített fogalmát akarjáli megalkotni annak a magrar nemzeti arczulatnak, a mely 1900-ban Európa múvelt népesaládjainak rendjébe sorakozott.

Csupán és egyedüil az az erkölesi nagy súly, a mely ennek a kiadványnak a kormányzat és egy központi tudományos intézet részéröl megadatott, csupán ez birt reá, hogy e könyrben magával a dolgozattal is foglalkozzam.

A kiadott arczképek nagyban és egészben elüitnek attól, a mit közfelfogásunk és nemzeti érzületünk "magyar tipus" alatt ismer. Különösen a mi az arczok kifejezését illeti, a nyújtott anyagban nem tükrözödik à magyarságnak egyetlen jellemronásia sem: söt sokszorosan annak ellenkezője jut érvényre.

Annak, már a magyar közrendü ember szemében is megnyilatkozó nyugodtságnak, hatálozottságnak és innérzetnek, azokban az arczképekben még nyomát is hiába keressük.

Már pedig semmi kétség, hogy az arczképnek a\% anthropologia s\%olgálatában minden tekintetben jellemzönek, az ábrázolt ember lényét is risszatuilirözönek kell lennie.

Nagyban és egészben azokkal az arczképekiel szemben a\% a benyomás támad, minthal úgrnerezett 


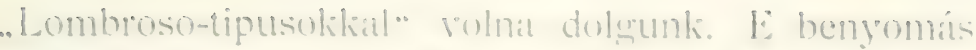
okital is foglalkozik e kionyro ment a tis\%tizits a tudominy érdelic.

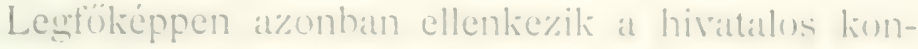
gresszusi kiadrány mindarval, at mit sajuit liututit-

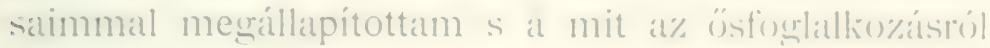
készüilö munkím keretébe színtam.

Minthogy nem lehet c\%éls\%erü at tudomámyos köröket a kongresszusi kiadrámy tartis hehatása alatt meghagrni, ez is inditott arra, hom a tipusrat vonatlio\%ó rés\%t már most lï\%rehocsíssam.

Hogy ebben a tekintetben mire tijrekedtem, at\%t a következö pontok fogralják magrukan:

1. Tisztázni igrelicztem a faj fogalmát.

2. Igyeheztem, hogy a ..régi szabásboj" annyit mentsek megr, a mennyit mégr lehetséges volt.

3. A\% arcz tekintetéhen belevontam a somatikus testi - rész mellett a lelki - - psychikus - . rés\%t : ennek rendén pedig az arczjáték - mimika - - és arczulat fiziognomika - liölcsönösségét is; mégr pedieg s\%élelesebb alapon, mert irodalmunkiban elözményüik nincs.

4. Az irodalomból. illetékesek kïzléseiból és a

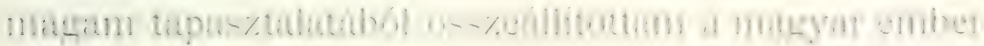
jellemzését, mely nélküil a\% anthropoloçiai hép töliéletlen, mert néma.

- I nem éppen kïnnyou feladat megoldásánál soks\%orosan éltem jó embereim támogratásálval is.

Hálám és höszönetem lecrelsó helyen l'A.uBi:k! Armsxt, az örökifjú mestert illeti, hi esıetlen s\%avamra azonnal megajándélozott a maryarság soálmazására vonatkozó tömü̈r diagnózissat és öss\%ehasonlitó jellenzésével. Leliötelezett réui ju emberem

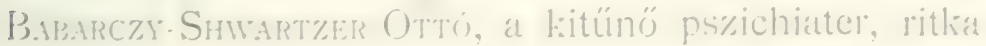


irodalom átengedésével; Makfalvay Géza jó barátom sok és igen kitünö összeköttetés megszerzésével; ezeknek révén köszönettel tartozom Vasdinnyey Aladárnak, Somogy-Kagrbajomban, sok, szerfölött becses fényképért; KaCsoH PÁL körjegyzönek az ösi „csimbólk“ szabatos megfejtéséért; ТuBa János régi jó barátomnak közbenjárásáért; Kovícs JÁnos-nak Szegeden és gyulai Gaíl GASTON hü emberemnek becses arc\%képért: Ruday Belat Budapest székesföráros fökapitányának azért, hogy a gonosztevők arczképsyüjteményét mestekinthettem: S.rorir keszthelyi fotogratusnak kiválóan gondos felvételekért, ugyanezért WrTwaw fotografusnak Komáromban; ugyan-

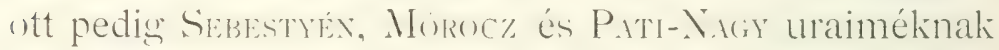
szives készségökért. És a kit elsőnek kell vala elösorolnom, küszönetet mondok mindig készséges, kitünö múvészemnek és barátomnak Koszkol Jesö-nek rajzaiért.

LaUfenauer Károly barátomat, a kitünő pszichiatert, ki alig egry héttel halála elótt régignézte arczulati meghatározásatinat és irodalommal is támogatott fájdalom - már csak haló porában köszönthetem. Kelt Noviban, a magyar tengerparton 1902 július havában.

Hernay Ottó. 
I MAGYAR NEP ARC\%A. 



\section{BEVEZETES.}

\section{A KIINIDÚtÁs.}

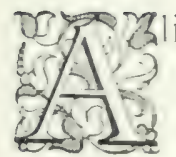

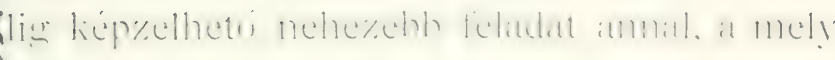
egy adott nemzet arczát úgy akiarja jellemezni, hogy ebben a jellemzésben a nemzet összességének arczulata tükrözödjék visszal vessen világot a nemzet lényére.

Legnehezebb e feladat a\% "ó-világ" múvelt nemzeteivel szemben, a melyelinél a történelmi menetnek változatos mozzanatai már maguk is sokszorosan keverödést és ennek rendén az eredeti, vagyis kisebbnagyobb mértékben faji jelleg módosítását, elmosódását, nem egyszer enyészetét jelentik; még pedig leginkább az arczban.

$\mathrm{A} z$ értelmi tekintetben legmagasabb folita emelkedett népek - ma kizárólagosan a mérsékelt égörben Európát lakók - már nem is "fajok", hanem fajok keveredéséből alakult nemzeti egyrségrek, a melyekre

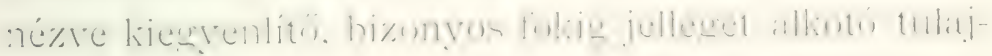
donságok, sokszorosan az értelmi fok befolyásától is erednek, a mely a hajlamokra, szoliésokra és czeknek kifejezö következményeire nézve nagyon kiható és igy alakító is. Hogy azok a küiönbözö temészeti riszonyok, a melyek kijzött a nemzetek éltek és 
élnek, reájuk nyonták bizonyos egységesitó bélyegüket, az ig̀en világos.

Állanak pedig mind ezek fö́képen az arczra nézve, melynek vonások szerint való összealkotása legföbb és legbiztosabb kifejezője az ember belsó életének. rérmérsékletének, hajlamainak, éréseinek, indulatainak, a nyugalomtól föl a szenvedélyek legvadabb kitöréséig; a szelleni nyugalomtól és ,lelki egyensúlytól" az örületig; a legmagasabb értelemtöl a butaságig.

És kifejezôje különösen az értelmi fok átlagának, a melyet az adott nemzet elért; ezen belül pedig annak az értelmi foknak is, a mely az egyén tulajdona s a mely egyénröl-egyénre különbözö; így az arczulat kifejezésében is az. De kifejezóje annak a tudatnak is, a melyet az adott nemzet történetének menete benne kifejlesztett.

Európa mérsékelt övének különösen az a része vesztette el arcz szerint szorosan vett faji jellegét, mely rész földirati fekvése szerint medrét és útját alkotta annak az emberáradatnak, a mely egykoron Ázsiából, „az emberiség bölcsőjéból* indulva, napnyugotnak vette irányát, halomra döntve mindazt, a mit a klasszikus ó-kor teremtett; elsöpörve, vagy elregryitre erös fajnépelict; eltörolve, ragy elvegritre hatalmas nyelveket, a melyek klasszikus, magas müvelödési fok tényezöi voltak és a melyek, késöbbi korra maradt ennékekböl foiltamasztva, a legrejlettehb mürelödés forrásit, eszközét s\%olgáltatták és folỵton szolgáltatják ma is.

Annak a nagy emberáradatnak a maga egészében és részei szerint nines pragmatikus története; nem ismerünk ilyet Európa sok részére az elözményekre 


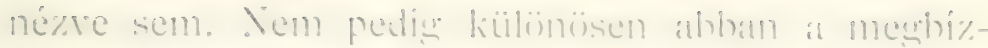

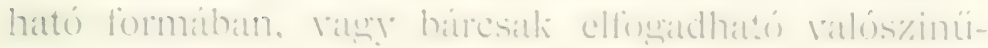

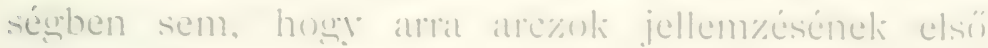
Riscirleteit alapithatmoki.

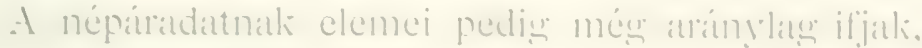

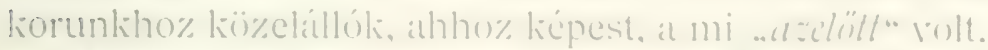

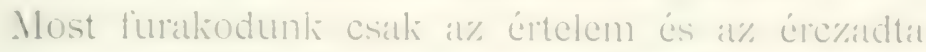
szerszammal a Dilurium rétegreteibe. how a palateolithembernek - a mammut kortársinali - nyoundoliatit ielkutassuli.

Mit nyujthat ennek a némat, illoj réternek less-

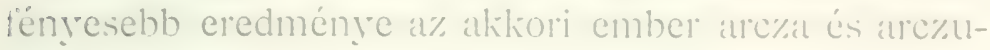
latal tekintetében:

Mesybizhatót semmit!

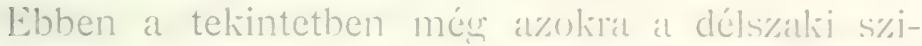

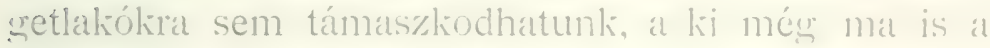
kökorban élnek, mert a foldirati és vele a\% éghajlati eltérés oriási, ezelinek befolvása at atrczulatra šülséghépen nagỳ és mélyen jálró, mihelyt al mérsélicelt ijv egykori emberéról vaun s\%ó.

De térjünk rissza a kïzépliort megrelözü àsiai

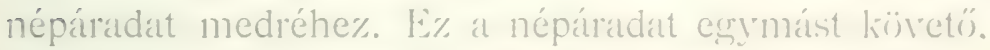
soliszorosan egymásra toluló emberhullámohát alliotott. Ess ténvleg a hullámzás törvénye nyilathomott

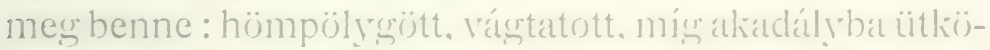
zött; ezt csapkodva ostromolta, am yi erouvel, a menny hadakozó elemében lakozott: néhát mewhígtal a\% aliatdályt, egr részérel át is csapott rajtat: at másile rés\%e

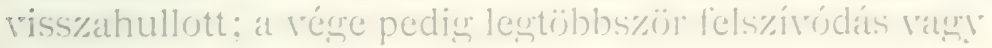

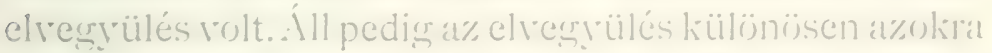

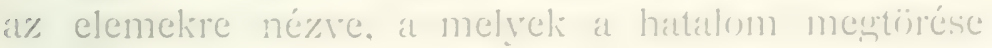

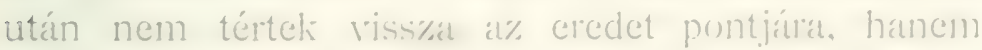

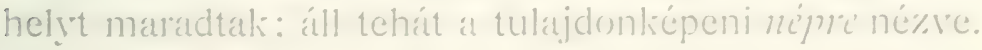


Küï̈nösen az arcz kérdésében iş egy valóságos ..kháosz" elé kerüilünk, melynek alkatelemeit, azoknak lešármaztatását megkisérteni hiábavaló fáradozás: különösen lehetetlen akkor, a mikor konkrét alkalmazás a feladatunk.

Így állunk az arcznak ú. n. somatikus, azaz testi része dolgában.

Másképen alakul azonban a viszony, mihelyt á psychikus - lelki — részt állítjuk elötérbe, vizsgálva ezt hatásában különösen az arcz testi részére. Ezen a téren nines kizárva annak lehetósége, hogy pragnatikus történet nélkül is bizonyos összefüggést kaphassunk, vagyis az öseredettöl fogra induló sorozatot alkothassunk, melynek lényege im ez:

A mennyire az emberi Nem fejlödését egyáltalában elgondolhatjuk, még pedig viszonylatban az állatvilág közös tulajdonságaival is, el kell fogadnunk azt. hogy a psiche bizonyos hatásokra, illetóleg ingrerekre mindég felelt és hogy ez az arczban ki is fejezódött. Az öröm és ellentétje a bánat, a szeretet és a gyülölet, az önzés és ellentétje, a gög és a szerénység, a vágy, az irigység, a jóindulat stb. és ezeknek ellentétjei, ezek mindenha nvilatkoztak, kifejezödtek és nyomot is róttak az ösök-ösénél éppen úgy, mint a mai kor emberénél. A különbség annyi, hogy az ässzes riszonylatok nyersebhek, liczdetlegesebbek roltak, a minthogy ösibb állapotban levö népeknél nyersebbek és ebben eĝ̣behangzóbbak még napjainkban is. De megroltak, hatottak és megnyilatkoztak mindenkor. És ebben a ,mindenkorban" megvan az az, összefüggés, a melyet az emberre nézve más téren. nevezetesen a történelmin, hiába keresünk.

De hogyha erre a psychikus, szakadatlan sorra 


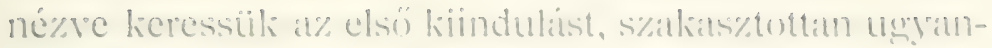
a\%on lehetetlensémbe üthö̈ünk, a melyet a\% emberi

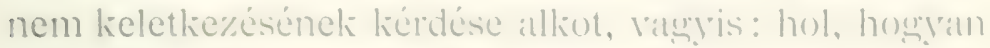
és miképen keletke\%ett à ember? fejlüdése melyik fokitn keletkeztek emberi émelmei és indulatat :

Evvel a gondolatmenettel csodilatosan esphehangzik az, a mit ifjú tilozotiai iskolánk envik leshkép-

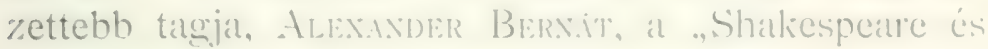
Latona" között vont páros huzamban ing fejezett ki:

.. . a a szervezetet genetiliusan kell magyariznunk; a sacllem terin isodis contimuilis timbl fil

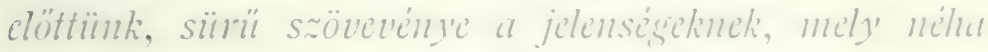
"r legtiunlabbit is egybeköti. Hogyan enthetno"k mes ai egyest. Ta nem ebben a kaposolatban néanike?.

.. Igaz, hogy sürúl fätyol takirjal a s\%ellemineli fejlödését és minél nagrobb ennek a\% értélic, annél rejtelmesebb a keletkezése. I)e éppen azért minden kis világosság hasznunkiáa válhatik:"

.-A tömegnek, mint ilyennek, megran a magnal kiilön lélektana

Ehhez hozzá tehetjük, homy mindazoknak a\% egry-

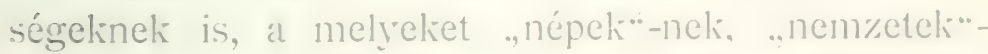
nek nevezünk, külön, mert sajátos, egrés\% lejlödésüikböl folyó lélektanuk van; éppen úsy, mint at népeli és nemzetek keretében alakuló kisebb engleségeknek és le az egroses családokig is. A lélek saljálossálgai pediy szükséghép lifelé is tükrözödve, láthatóvít tes\%ils àt is, a mi a\% egrségeliben kizois. de ath is, a mi meorkiülönbijztetó tulajidonsás.

Semmi kétsére, hogy a\% a hatalmats genctilius

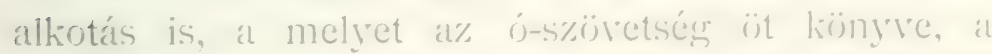
.Pentateuch:", foglal magában, at melyet al kij\%tudat egy embernek, Mozsis-nek. tulajdonit, s\%alials\%trottan 
ugyanazokba a nehézségekbe ütközött, a melyekkel megismerkedtünk. És éppen ezért kellett az ismeretlen elözményeket közérthetó és reális alakban a psychéból kiteremtenie, hogy azután úgy a testi, mint a lelki - tehát somatikus és psychikus — részben a valóságig eljuthasson, ennek a jövöre irányt szabhasson.

Mielött azonban ebbe belébocsátkoznánk, álljon itt az, hogy a bibliával foglalkozó tudomány Mózses öt lönyvét - a Pentateuch't — már nem egy ember múvének veszi, sốt részei szerint még különbözó korbol is soimmatatja, hogr tehat azoli, mint egredül Mózses szellemének szülenényei nem is tekinthetök.

Áll azonban az, hogy a Pentateuchnak Mózses s\%emélyével való közretetlen, szerves kapesolata, mondhatni azonosítása, éppen a biblia roppant elterjedésénél fogva annyira belenött, meggyökerezett a közfelfogásban, hogy azt zavar nélkül rövidesen és egyszerüen kiküiszübülni nem lehet. İg takán čélszerúbh lesz itt, a hol nem szövegek kritikai, eredet szerinti és chronologiai megúllapitátsúról, hanem a Pentateuch tartalmának némi összehasonlító alkalmazásáról van szó, Mózses nevét mint összefoglaló médiumot alkalmazni.

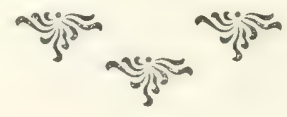




\section{MOZZSES KIINDÉLALA.}

(9) belátjuk, hogy ö liétségkíveiil a\% emberi nem legnagyobb és legtudatosabb történetirója és ezen az alapon történyalliotója. Nem abban a\% értelemben rére a történetírói nagy sásgot és allialmazrat a mértéket, a mint ezt korunk történetiró natsysásgatira értjük és alkalmazzuk, hanem egészen másban.

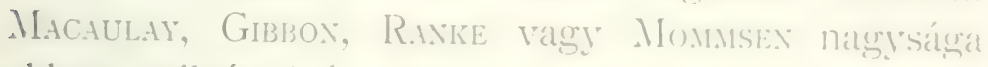
abban nyilvánul és gyölierezik, hogy ezek a nagyoli kritikailag megállapitható, legtöbbszior okmányokial is támogatott tényekböl szerkesztették meg történeimi képeiket és ezekböl ronták le kijvetkeztetésciliet ús tanuságtételeiket.

Nem úgy Múzses!

Ö választott népének és ebböl kifolvólay az emberiség egy nagy részének - nemesak egrtoron. hanem ma is elevenen hatra - megrirta a vilám teremtésének menetét, ezt a semmin, vaýy a khít)s\%on kezdre és kora társadalmáig épitre: még pedig oly formában, hogy közérthetöség mellett megnyugraíst nyujtott a közepes emberi elmének, tehát at leegnatgyobh társadalmi hatalomnak. Fis at midön èt véughezitte. törényaalkotóvá alakult át.

Mintha kora görönesérjét rette bolnat alapul, at ki Hepuas: a mazyar nép arzai. 
az anyaföld testétól elszakasztja az agyag-gomolyt; gyúrja, hogy formálásra alkalmassá tegye; rácsapja a korongra, hogy megtapadjon; elindítja a korongot és ekkor kezének nyomásával edényt alakít; tehát a nyers anyagból, mely formátlan kháosz, indúl ki és müreletek estrmatsutanjátal, melyek idöt is jelentenek. edényt teremt; azon módon Mózses-nél: az Úr a kháoszból nem csodával, egyszerre, hanem a múveletek egymásutánjával, számszerint hat fogással idónapok — teremti meg a világot.

Így kapesolja Mózses össze az Úr hatalmát a közepes emberi értelemmel, mely minden téren, anyagiakban és szellemiekben egyaránt, csak idöhöz kötött, így idớt jelentő egymásutánnal tudja alkotni a legegarlobbat és a legmagasztosabbat egyarant. A közepes emberi értelem, mely nem hajlandó a lét kérdésének végső okait kutatni, feszegetni, élete folyásának, a reáható jelenségrehnek egromásutánját is igy látva és érezve, a világ teremtésére nézve megnyugszili Mózses kiindúlásában — a folyamat szövésében. És csak miután az ember megélhetésének elófeltételei meg vammak alkotra, következik a\% ember maga.

Mózses genezisében az Úr nem indítja meg a megalkotott világegraetem vajudátsiból eredó, tengerek fenckén serkedezö protoplazmas sejtelmes, titlon lappangu(i) életét; nem gyújti s nem csoportositja a sejteket, nem indítja azoknak oszlását, ebben a különbségek legelso" foliozatainak nyilránulásit: nem ehboil és e\%eliból alkotja meg az elsó embert, hanem ismét csak mint a göröncsér: elóveszi az anyaföld formálható faját, az agyagot - azért az anyaföldét, mert a megalkotandó embert egész anyagi létével ehhez kell 


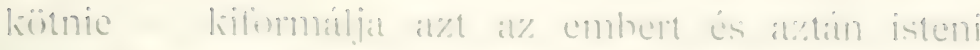

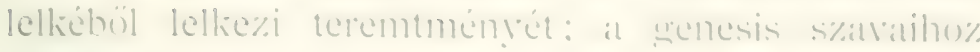

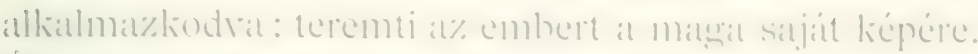

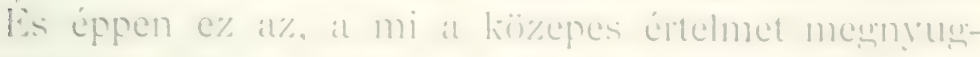

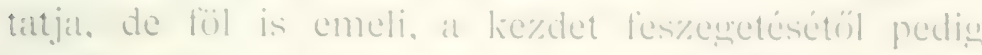
tilvol tartjii.

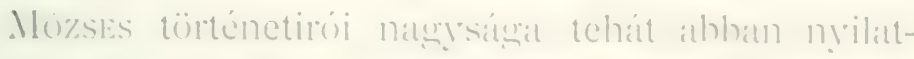

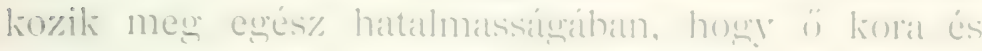
korok emberének felfogható is mennyugtato kiindu-

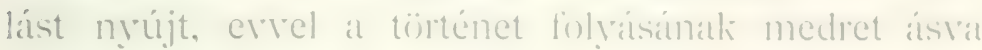
iranyt szab at jüröbe, mely a hïzepes elmét, tehát at

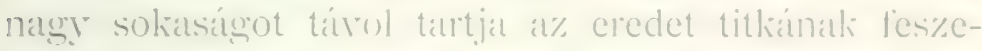

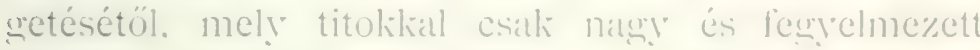

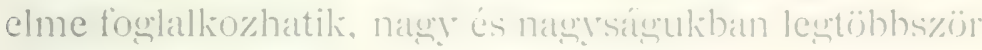
réç\%etes téredésel ves\%edelne nélliuil.

\section{A SOMA IIS A PSITOHE.}

Rendkiviil vonzó elmebeli foụlallourás Mozses-1 módszere kifejtésében és allialnazásában kijvetni: hogyan fejti ki a tilalom fogealmát abból, a mit nem

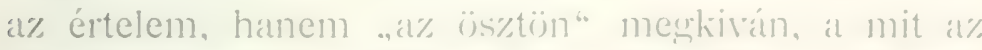
immáu történy hozó Mrozses korlátozni akar: hoglean s\%ámaztatja a paradicsomi tilatonn mess\%ecréséból a bün fogalmát és mint a\% elkijvetett bün folỵmanyait a büntetést, a megrorlást: hogran lapesiolja ös\$e ezt a sorozatot a veritélies munlia formalmáal at

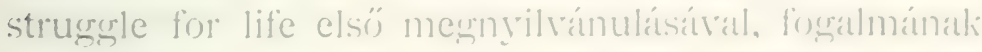
mergalkotásával - és réure at halandiságrgal.

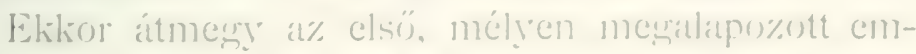

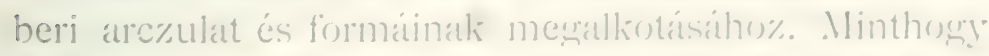
at halandoság forgalmal mers lan allapitra, a tipus 
szerint valo mestiulönbüztetést atz életböl és ellentétjéból, a halálból fejti ki.

A mohó, önzó vágy egybeszakad az irigységgel - Kain - és e kettóból fakad a gyúlölet, a bosszú indulata, melynek vége az erőszakos halál: a gyilkosság fogalma.

Es íme elöttüink áll a gonosz ember és merö ellentétje — Ábel - a jó; megnyilatkozik az elsó, uj bün: a szímonkérés tényéböl pedig kibontakozik az eltagadás ragr hazugság, melynek nyomán föltámad a lelkiismeret, a kín egész hatalmával.

Az áldozásnál az Úr nem a Kainét, hanem az thelét togadja kedrezöen. Kaint elfutja az irigrsés dühe és ekkor: . . „mondá az Úr Kainnak: Miért gerjedett fel a te haragod? és miért változott meg a te ábrázatod?" Mózses I. 4. 1. 6. v.

A mezöre érve pedig, Kain leïti Ábelt!

Állapodjunk meg az Úr második kérdésénél egy pillanatra. Tisztán és viligosan lathatjuk, hogy Mozses merithetett ugran hagronányoliból, de nem merithetett torrténelmi adatokhól, mert hiszen azt räolja. a minek történetileg meghizonyitható, reális nultja nincs és nem is lehet; de a mit a végczél érdeliében ‘ közepes emberi elmével el kell fogadtatnia, még pedig mozzanatok meggyözó erejénél fogva.

Erre csak egyetlen módja és forrása van: $a z$ cmberismeret, mely Mózses-nél úgy általános tekintethen, mint sajait fajanak tulajdonságatara nézve, valóhan hámulatot keltö; söt a korra való tekintethöl szinte

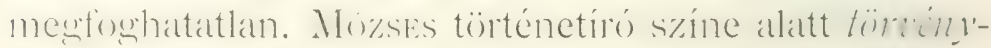
alkotó s mint ilyennek hatalma, erössége az alapos emberismeret. 


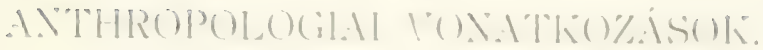

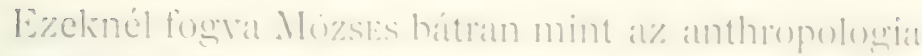

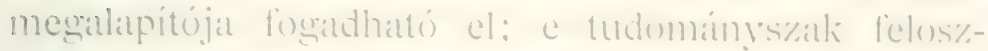

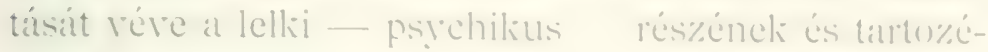
kainak minden bizonrnyal.

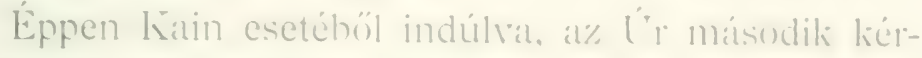

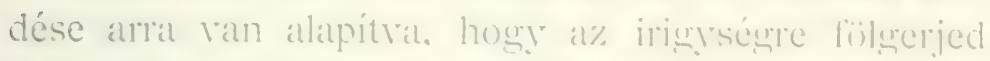
at harag, e\% elváltoztatja az ábrizat kifeje\%ését. ment a felindúlás átalakifólay hat az arez ideszetén at izomzatára, vagyis a psychilisus serjedelem visszattükrözödik az are\% somatikus rés\%én és minde\% foliozỏdik a şyillosság büntudata, a lelkiismeret föbéledése, a furdalásnak kínja alatt; kïilönösen a\% addig a szenvedélytöl šüz ember clsö bünćnél.

Az analizisben eddig haladra, at helyoet isy alaliul: a tett nyomán fölébredt a büntudat, ennek behatásáláa

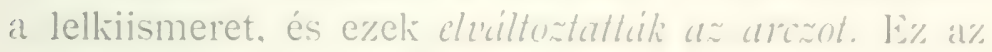
elváltozás belsö, ú. n. lelki ösztünböl kelve, elsö alakulására nézve az arezon mimikui és mint ilyen ill a kutató szeme elótt.

A mimika, mint olyan, kapesolatai s\%erint lićt részre bontható, ú. ma a lelkire - psychikus és a testire - somatikus. A lelkinek ideringerére menmozdul a testi - a\% elöbbinek alávetett i\%om és mo\%gása, az arczizmok összessécének vasy rés\%einek at lelki - vagy ideginger behatása alatti alakulásat s\%üli ¿z arcz küilönbrizö) kifejezését az l'ir értelmében a\% .elvailtozásokat".

De ezekre a mimikai elvaltomisolira nére ismét két csoportot kell alakítanunk, ú. m.:

1. Az ergymást kijvetö behatásoli alatt röjertion keletkezö és syorsan múló, igy tisztín mimikat 
ilyen például a nevetségessel szemben a hirtelen keletkezó és múló nevetés egész skálája, melynek állandó nyoma csak idó során kelhet ki - a víg ember, a szomorú ember állandó arczkifejezésében.

2. Azt, a mely tartós, el nem múló, akár psychikus, alsill somatikus hehatás alatt keletkezik, megmalrad és éppen ez által az adott arcz állandó jellegét alkotja meg. Vagyis: a múló mimikait a somatikus elemekre való igen tartós, vagy állandóvá alakult behatás fizio-

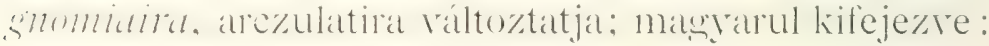
állandó arczulattá alakítja.

Hogy Mózses anthropologiájának psychikus részével végezhessünk, a mennyire t. i. itt bevezettük, KAIN-ra nézve az utolsó mozzanat az, hogy a büntudat és a lelkiismeret állandó nyomása alá kerülve, mely psychilius hatalom, arczulata szükségképen

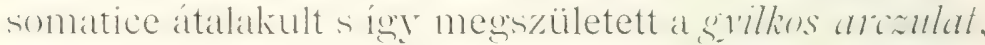
mai szóval kifejezre Lombroso gonosztevóje, a „7homo delinquens".

Az elsó emberpár keletkezésétól, tehát az éden ahs\%olut ártatlanságától kezdre, e pár elsó ivadélíign. már meg van a rettenetes fokozat: a gyilkos tipusáig. Az emberiség mai, magasra fejlödött társadalmára, az ú. n. kulturnépekre alkalmazva: a fokozat az alvó

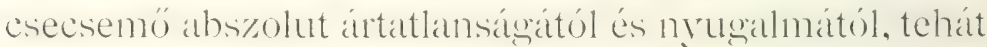
a psychikus és somatikus egyensúlyon kezdve, megszámlálhatatlan változaton át elvezet a mámoros állapothan fetrengö, lelkileg elaljasodott. somatice felduilt

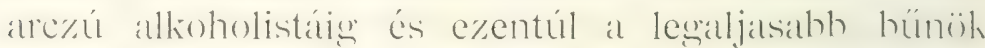

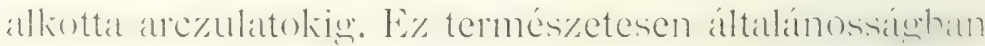

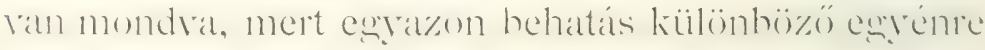
nem ugyanaz a kifejezés fokozatában; ám ez más lapra tartozik. 


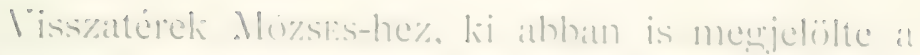
kiindulatsi pontot, at mi nepeit a\% embertipusole soleit-

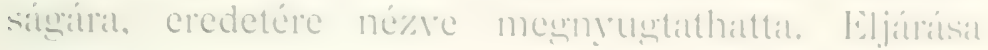
natgron írdelies, naty emberismeretre timats\%linder.

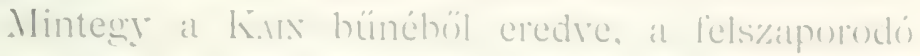
nemzedéliek hünbe sülyednck, ezchet elsiopri a\% l'p

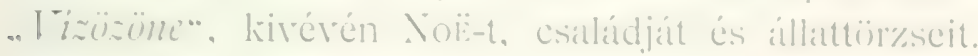
Ezek, a rizek lefutásal után, henépesitették at tíjaliatl.

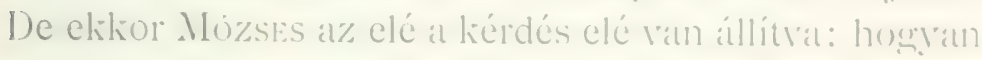
ny̆ugtassa megr népét a\% embertipusoliar néze, melyeknek különbségei mál a nyelyek sokfüleségében. úgy a bör szinezetében és esyebeliben is natylon szembeszöliöen láthatók voltak :

ö nem folyamodott, mint mi, a jéghors\%aliho\%. mely oly kényelmes sok mindenféle kiindúlátsi pont föltevésére: sem ahho\%, a mit Bu(kL: az anyol múvelödéstörténetében oly nagy éleselmúségrgel mangrarizott, t. i. a termés\%eti riszony̧oknak at embere gyakorolt átalakító hatásához, hanem ismét elövette emberismeretét, a femmléjázó. hivalkodó ember lelkïletét és erre alapitotta a jelenséco masprarazatát.

Az ö felszaporodott társadalmá téchlát ke\%d éretni. meszet olt, hozzáfog a város épitésher és hivalkodis. fennhéjázó indulattól sarliallar, oly torony épitésébe

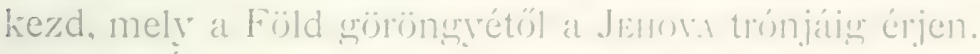
Ezt az Lir nem engedi firikati lehetellensés.

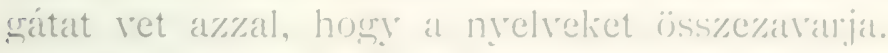

Ez az osztro ely a\%, mely a\% értelmi liöćps\%erneli

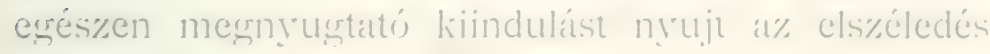
tekintetében. A mai emberismeret nyelién kifeje\%c: a\% 
alemek a mü kivitele. lehetöségre és módja fölött „szétkiilënbëztek" és elsøéledtek. Innen az emberfajok eredete és sokasága.

\section{A FAJ És A VALÓSÁG.}

Megérkeztünk volna tehát a tipusok kérdéséig; de nem úgy, mintha a keletkezésre nézve Mózsés yeneziset fogadnók el anthropolograi alapul, hanem crak a\%ért. hosy emberi elmével felfogható pontról indulhassunk ki.

Naptárszerúen a "világ teremtése óta" ez idén a 7773-ik évben volnánk; a geológia azonban arra tanít, hogy ez a szám a Föld korszakainak menetében egy másodpercznek oly töredéke, mely úgy viszonylik a korszakokhoz, mint az ember lépése ralamely állócsillag távolságához. De hát azt a 7773-as számot az értelmi kïzépszer fölfoghatja, nálunk magrararokál is. kik a mostani területen elfogadhatoan az elsó ezer éret kitiiltrittuik. Azonban azt is tudjuk, hos ennek minden elözménye és kivált kezdete, bizony sokszorosan ködbe borul. De hát haladjunk és vizsgálódjunk.

Annyi bizonyos, hogy a majdnem nyolcz ezredér lefolýisa alatt az úgrnerezett ó-rilág emberisége roppant aramlatokon, helyráltoztatásokon ment keresztül, a melyek mind módositólag és hizony átalakitólag is hatottak mindarra, a mit „tipus" alatt megállapítani lehetséges. Es mükïdött kïlönösen a\% e téren lesnatgrobb allioto és átalakító hatalom, melynek neve: elvegyiilés.

Közszólást használva: az ember feje szédül az

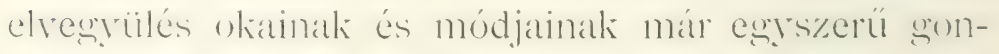
dolatára is.

Íme egy kép: bizonyos faragrányok nagyon való- 


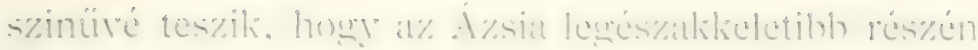

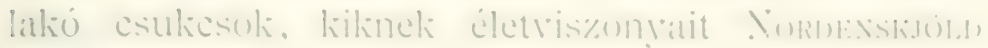
ismertette mese hires telelése remdjén, at mikion at

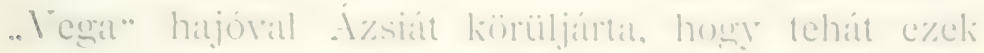

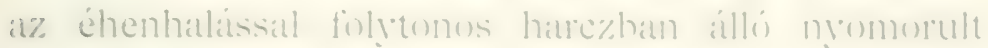

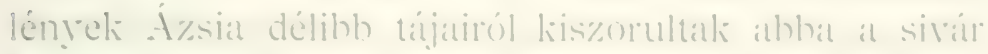
kietlenséurbe.

lannak támatszópontok anra nézve, hosy at és\%alki sarkhör inazi régridékét lakó es\%kimoik tömstátjának nyökerei boldomabb vidékrol is eredtek. Mar pedig ezek a néptöredéliek úğ vis\%onylanak a\% emherisén natgy tömeseinek korszakok sorin való itramlasiho\%, mint

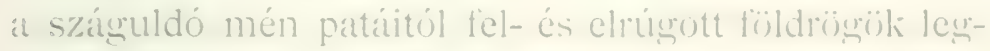
lisebb és éppen a\%ért leurmesszehbre esö mor\%siit. I felrúgás és kavarodás ott a legnacyobb. a hol a mén patája bevágott és a honnan kirúgott.

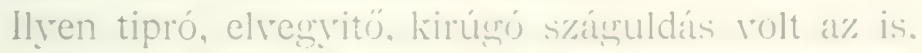
a mit a történelem és az archaeolougia a . néprándorlás korszahának" nerez, a mely hr. u. a negredili szizatdban az ó-rilág heletjéról indul, eleánolja at hatalmas római birodalmat, irtja és elnyeli az alikoron élt nép-

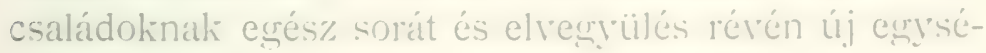
seket teremt.

Ervel ismét elértük a kiindúlásban érintett népiradat medrét és felrethetjül a konkrét format.

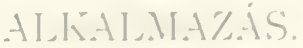

E tipró és elverrýtö s\%átruldásbol mi masyourok. még pedies kialakult, ránk nevelt történelmi tudat alap-

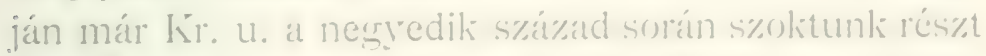
kérni, més pedies à humnok rettentó) fellépése révén. at melyeknek áldrozatul csett a siotholi hatalmas biro- 
dalma ús a kikkel a székelységet hoztak némelyek kapcsolatba. Elfogadható az, hogy a hunnok a magyar Alföldön megtelepedtek.

A hunnok megtörtek. És ekkor, a mi reánk nevelt történelmi tudatunk "tabula rasa"-t gondol, a melyet azután avarok töltenek be, kiket Carolus Magnus, a grermánok hatalmas crászárja, csale a nyolczadik század végén birt megtörni, a mikor ismét „tabula rasa"-t s\%oliás gondolni, a melye végre a tizedik században a magyarság kerüil.

De nemcsak lehet, hanem kell is föltennünk, hogy mindazoknak a száguldó néphullámoknak, a melyek a mai Magrarország terïletén megretették lábukat, idök során itt csak hadihatalmuk tört meg; ez tünt le, enyészett el, - részben talán visszavándorlás során is.

Az azonban, a mi népelem volt, habár csak részben is, de megmaradt, hoggr az áramlás rendén a hatalomra vergödö vagy lépó új hullámmal elvegyüljön. A magyan történelem az ethnográtiával és archeologriával karialtre eat ismeri el mint mescallapitásainak elsörendü feladatát és hogy ez mélyen helevág a tipus kiérésébe. az csak temészetes. Es ekkor itt az anthropolongia feladata.

Ám a magyar tipus kérdését nemcsak a fölvetett nagry elvegryitó, elenyésztetó népáradat neheziti, hanem nehezíti küilönösen az is, a mi nagyban és egészben már történelmi idökiben folyt. Az ország a világrész középpontjához tartozik: mélyen fekrö síksúça hegrységektöl körülvéve, nyugotrat nyiló medenče-feneliet alkot; a medenczékhe pedig gördül minden felszahadult katics, rög és ehbe siet minden megeredt lizosiopp: a gratritáczio törényénél fograt. Fs a medenczék televényes fenekére eres\%kedik minden idök hóditó hatalmat 


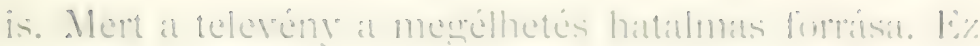
is millitilivi)

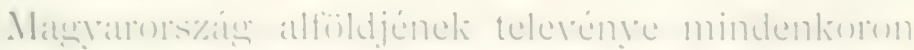

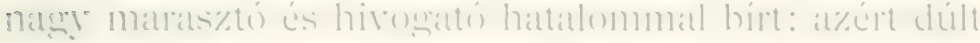

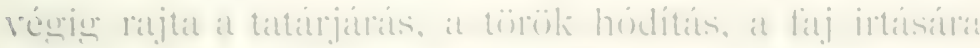

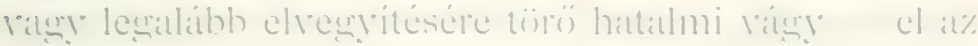
iij koris.

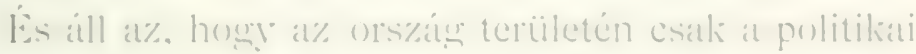

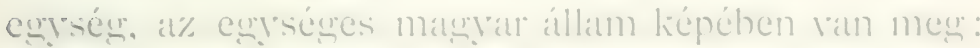

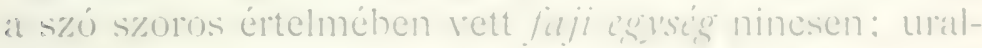

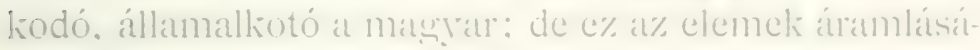

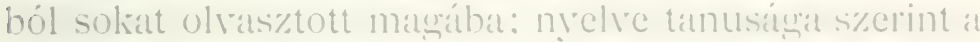
messze multak homnálvähan is sok elemmel érinthe\%ct és körüilötte mai területén és mati napiọlan is s\%ünctle-

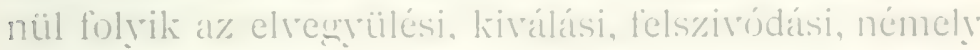
ponton mintery endommotilius fulyamalt. Hat ehlne\%

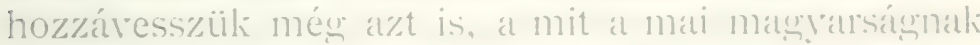
úgyszólván már fölszinén is látunk. a\% uly necyliülïnbözött rés\%eket, mint a kunok, jás\%ok, bessengöjk. patri-

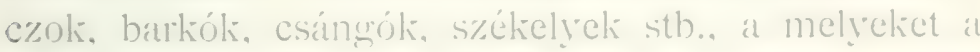

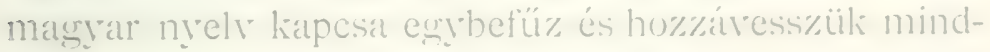
azt, a mit esali az öss\%ehasonlito nyelvés\%el, a nép-

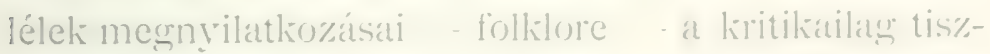

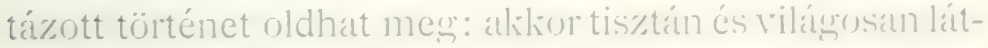

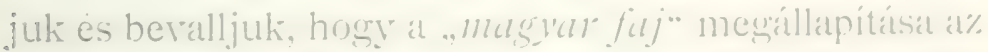
anthropologiának lesnehezebb problenuáli liöce tartu\%ik.

De az is bizonyos, hogy a feladat mesoldásid elsio sorban magral feladat, altól risszariadnunle mem s\%atbad, mert mi állunk legkijzelebb satjatt tijrténelnuinhhö\%, mi pillanthatunk be lesmélychben a néplélelibe és mi itélhetjük mes leshiztosabban a tátradalmi alat-

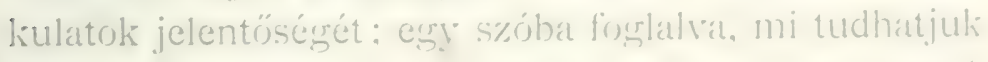
meg és érezhetjüh is lerjobban, mi a\%: "makman". 


\section{TÜZETESEBB MEGHATÁROZÁS.}

Annak, hogy mi az „magyar"? meghatározásában tudományosságunk körülbelül oly helyzetben vát, mint rolt Mozsss az emberiség liérdésében. Ennek somatikusanthropologiai részét Bíl. király névtelen jegyzójének krónikája alapján csakusgran nem tisztázhatjuk; nem dionthetjük el a faji kérdést lege artis az emhertan mai kïretelnénye szerint sem, mert erre nézve az a krónilia semminemú alapot sem nyujt, a mennyiben följegyzései még a hatalmi menet és a nemzetségi egymásután tekintetében sem kijretelhetik maguknak a hiteles pragnatikusság erejét. Es igy vagyunk a krónilások ossszescégével szemben is, mihelyt a\% abszolut anthropologriai és faji érték lierdésćt retjük föl. A bizonytalanságok kháoszából bontakoznak ki a "Gesta Hungarorum", a melyeknek értéke maga is állításos.

Így és nem máskép állunk a "magyar" kérdéssel a testi - somatikus - anthropologia tekintetében. Ez nem akar kisebbitése lenni azolnak a nagy, fáradságos kutatásoknak, a melyek a számazás és fejlödés nag problemálját ostromolták és folyton ostromolják és sok nagyecsü anyagot retettek felszinre; de az állítást az okolja meg, hogy azok a fáradságos kutatások a régsó kïvetkeztetésben egymásnak sokszor, söt legtöbbször meröben ellentmondanak és ebben az ellenmondásban rejlik tagadása az abszolut értéknek, mihelyt faji tekintetben a biztos döntést keressük. Az „ethnos“ tekintetében itt van a Hunfalvy kialakult iskolája, mely ethnografiati és nyelrészeti alapokon Ásia és\%akkeleti

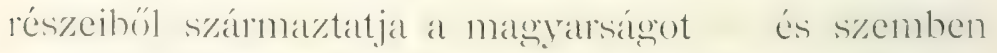

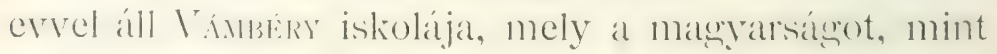
ithmost, nyelvével esyetemben kizilljat. Izsiabol! Közhe 
leggen vetre. hour e\% majd minden emripai kialakult nemzetnél is vam, maishéppen nem is lehet, mert mind-

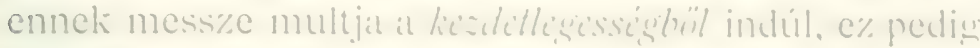
éppen coért szüliséplicppen hi\%onytalan.

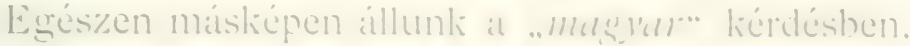
mihelyt a prohlema psychilius résect retjük fel és e\%t a\% emberismeret komponaján lituljuk, hory liojetle\%tetésekhez juthassunk.

Ha Mozses a felisment általínus emheri tulajdonnii-

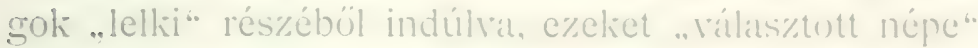
sajátos tulajdonságaival vetette enybe és a nyert ered-

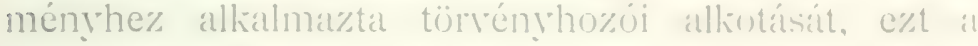
mindenesetre helyes utat mi is kijvethetjük at ..musy sag" kérdésében, mihelyt az általános emberit vesszüli és egrberetjük azoklial a ..lelki" tulajdonsádgokial. a melyek a magyraságra nézve sajátosali ma és a melyeket a multban sem ronhatott liétségbe alaposan senki sem.

Ezeknek a sajátos tulajdonsagoknak a megrillapjtása, az arezban való tülíüzödése e mú vérgčélja.

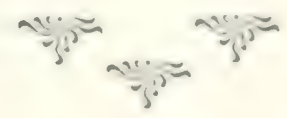




\section{A BBOSTTTLS.}

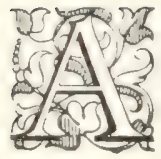

feladatnak szorosabb értelemben vett anthropologiai része most már így alakul.

Első helyen áll a testi — somatikus rész - mely a testi tulajdonságokat vizsgálja és egrhereti, hogy szimbeli atlagolibol sajatossígra köretkeztessen. Ez a rész kiváló súlyt helyez a méretekre.

E mellett áll a psychikus rész, mely a szellemi tulajdonságok equészét a maga egész kihatásában kiarolja fel. így tehát az ú. n. „folklore“ vagyis néplélektan körét is alkotja meg. mely a nép lelliéneli szavakban kifejezett eszmekörét s az ehhez kütött foggalmakiat és cselekményeket öleli fel, világot vetve a jellem sajátosságaira is.

A históriai anthropológia a harmadik ágalzat, mely a szalitudomány szempontjáhól vére az ember keletkezésérel és testi fejlödésérel foglalliozik, e dolgyozat kïréhöl aronban tudatosan ki van reliesztve. mert sorozatai - mint tudjuk - szakadozva-ingatagok.

A méretekre alapitott somatikus anthropologiához szegödik azonban a fiziognomika, az arczulat tana is,

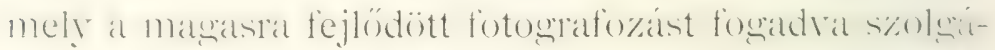

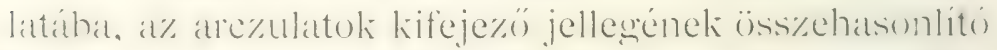
tamulnányoritsit tes\% lehetové és igen fontossil: de

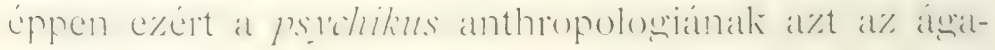




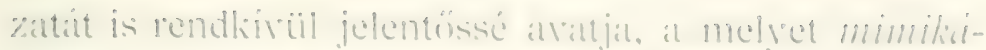

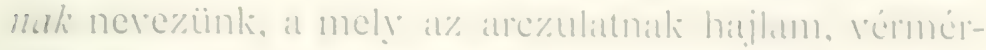

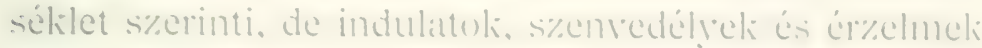

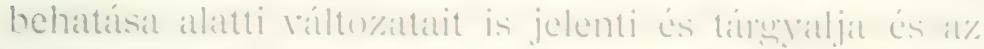

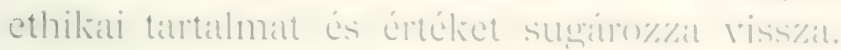

A tiziognomikil es mimikal s\%elres kitpesulathatm

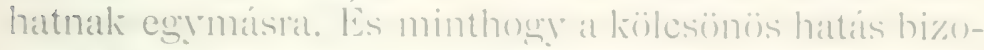
nyos föltételek mellett íllandó jesplelet teremes, semmi

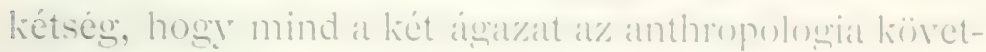

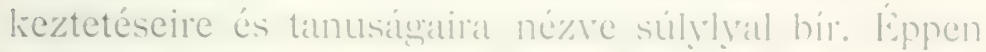

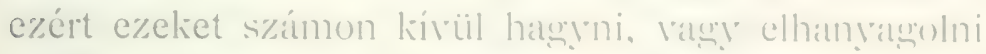

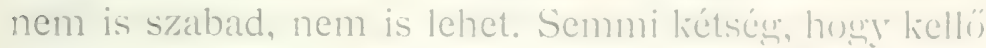
számú méreteliböl kivont aranyszámok alapjain meykïilönböztethetjük a\% eșrik nem\%etet oly nemzettöl. melynek méretekre alapitott arangsyantai lényegesen ragg észrevehetöen mások: de a pusztín testi méretekre allapitott tanusíg csak a test mérhetö anyagri különbségeit mutathatja ki: a lelki, jellembeli sajaitságokat, a melyeket csak a lelliület tükrözúsével, a\% arcz izmainak játékával és a nyomon tánaddú kifejezéssel bir kimutatni: ezchet a s\%olísos mérétivételekkel megállapitani nen lehet.

A magrar tipus arczulatának meshatairozisánál tehát, ezúttal némely somatikus vis\%(n)yon kiviil. különösen at két utóbbi ágrazat, at tiziognomilia és

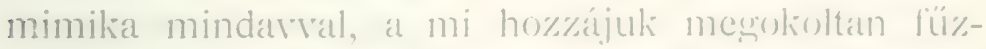
hetö, lép elénk, mint a feladat meguroldasinali leughntosabb rés\%e.

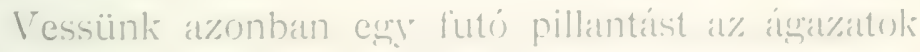

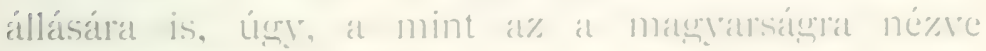
eddis kivehetö).

Mindar, at mi at letünt XIX-dili s\%irátd utolsis

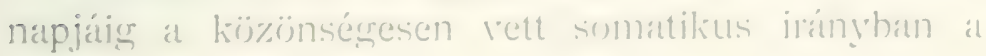


mágrarságy kérdésében történt, csak parányi töredék, mely az egyetemes somatologikus részben is csak magamagát példázta, a "magyar" fogalomra nézve pedign més csak halarány felteréshez sem nyujtott elfogadható alapot, mert egrebeken kiviul a történeti és tarsadalmi, ethikai stb. kriteritumok vagy teljesen hiányzottak, vagy elégtelenek voltak. ${ }^{1}$

Nem kisebb baj rolt eleddig a .magrar tipusoknak" rett, ragry föltett egryének ábrázatáról, illetöleg arczulatúról fölyett fénỵliépelinek vagy jo rajzoknak hiánya, mely oly szöverényes és éppen azért szerfölött nehéz kérdés megoldásánál, a minő a "magyar arcz" fogalmának anthropologiai teljes meghatározása, rendkivüli fontosságual bir. És meröben hianyzik még a kisérlet is arra, hogy a magyarság jelleme ethikai tartalma szerint, élete viszonyatival kapesolatban egy egrységes képben és ezen túl öswzehasonlító alapon összefoglalva megalkottassék.

Így ennek a szerfölött nehéz problemának az emlitetteken kivüil egryáltalában finomabh részeiben való megoldásához mége a nyelvészet, folklore, história és asszehasonlító ethnografia is hozzájárul: ezentúl igen lényeges szerepe és súlya van az arczképhez kijtött összehasonlitó vizsgálódasnak, tehát a fiziognomikának és mimikának is kölcsönös és alakitó

1 Ide tartozik WEISBACH müvében, ,Körperuntersuchungen verschiedener Menschenrassen" Berlin, 1878, a magyar fajra vonatkozó rész, mely mindössze húsz magyar katonán végzett méretekról akarja a "magyar" fogalmát megállapítani, a nélkül természetesen, hogy e katonák leszármazisára vonatkozó finomabb kriteriumokat megszerezhette és számításba vehette volna. Ugyanebbe a sorba tartoznak azok a töredékek is, a melyek irodalmunkban LeNHossék Józser, Körösi Józser, LÁzÁr IstváN és újabban mások nereihez füződnck. Ez nem kicsinylö kijelentés akar lenni, mert a feladat nagysága és nchézsége töredékül mutatja ki a korlátolt alapra fektetett, különben jó müvet is. 


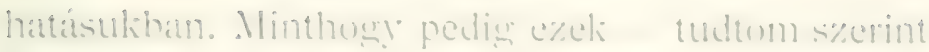

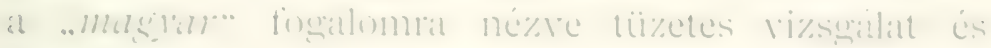

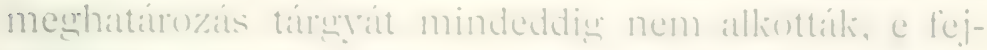
teretésneh czéljat pedigr éppen iz elliortillnetetlenneki velem. howy at vizsualat allialmatontt reszet mindench-

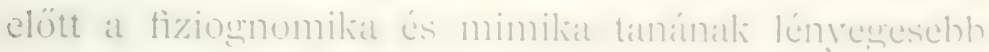
tartalmálval bevezessem.

\section{A FIZIOGNONHKA LS MIMIKA IILASA.}

\section{ARISTOTELES.}

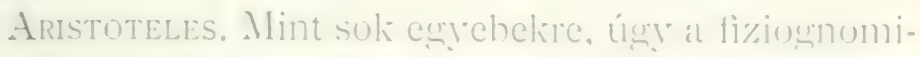

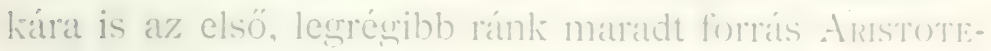
LES ${ }^{1}$, hi azonban megiengzi. hogl nál elötte is némelyek kisérletet tettek, bizonyos népeli esyoumiali.

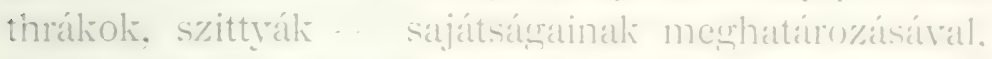
hogy azolinak más népelinél való föjismerése esetén. emezeknek lelki sajátosságaira kijvetheztethessenek.

Ez volna tehát az ijss\%ehasonlitio móds\%ernek elsï lépése.

Azt is kétségtelenneli tartja Aristuteles, howy at emberi ábrátzatban at szenvedélyek nyomot vésnek:

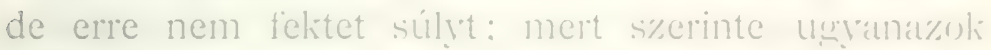
a lelki tulajdonságok nem engformain nyilathomnak: az ábrázatba pedig usyanazoliat a nyomoliat küiainbözö lelki ingerele is réshetili. Ans, csodálatostiépen. Stagira nagry bijlese. ismételve mondrat. éppen e\%clire nem felitet súlyt. noha mál benniji van mati felfográsunk csirája \& e valóhan natey clmének indulitiv.

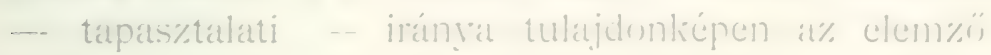

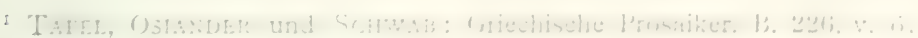

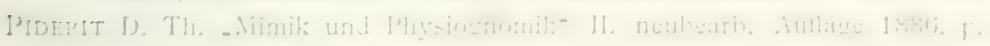
1tij. é. t. 
¿s äs\%ehatsonlíté eljarást kellett rolnat megragadnia és ajánlania.

E helyett Aristoteles azt vitatja, hogy az embereket a\% allatokial kell egryeretni és a közös jegrekböl a közös tulajdonságokra kell következtetni. Ez a módszer azután Aristotelesnél kisuiti, hogy a vastag orr — mint az ökörnél — az embernél is lustaságot jelent; a tompa orr — mint az oroszlánnál — az embernél is nagylelkúség jele; a durva ször - - mint az oroszlánnál és vadkannál — bátorság; a puha ször — mint a nyúlnál — gyávaság stb. stb. jele. Tehát nemesak a vonás, mely az ember és a gerinczes állat arczulatában már a koponya alapjában véve egreséces alaptervezeténél fogra bizonyos fokig megvan, s a mi, mint látni fogjuk, DARWINT is vizsgálatokra inditotta, hanem már a puszta anyagi tulajdonsag is. mint a ször durvasága vagy puha volta egyezó jel akart lenni. Aristoteles igy nem boldogulhatott.

\section{SCHACK SOPHUS.}

ScHACK. Ez a teljesen tarthatatlan nézet azonban idönként csodalatosképen föl-föléled és egrész komolysággal széles alapon — alig húsz évvel ezelött a dán festész és fiziognomikus SCHACK $^{1}$ foglalkozik rele. Fúses sorát adja az ugyancsali ojsizeerószaliolt fejrajzoknak, melyek szerint össze vannak hozva a franczicik ritéz tábornoka. KLÉBER feje az oroszlánéval, Bernadotte a sassal, Voltaire a majommal, Talleyrand a rókával, Ferencz császár a birkával, egy jütlandi ey thazti a pudlival, a párisi rikkancs az aguir-

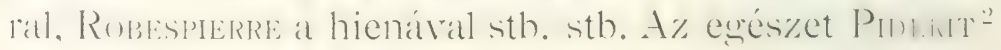

1 Scrack, Sophus: „Plyssiognomische Studien. Autorisierte deutsche Ausgabe. 1881. von Eugen Liebich. pag. 42, 115. ć. t.

2 PIDERIT i. h. p. $149-150$. 


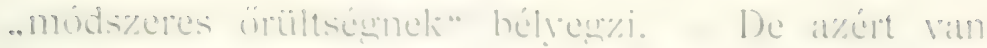

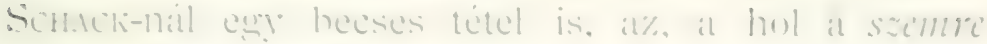

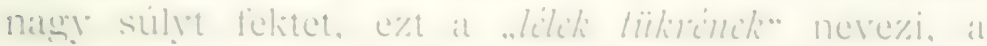

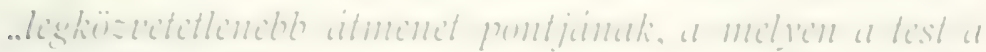

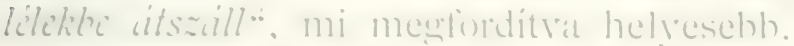

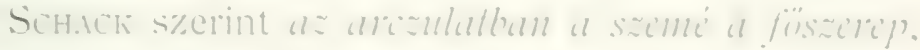

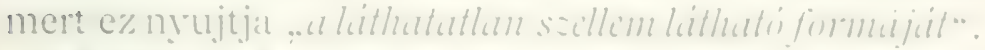

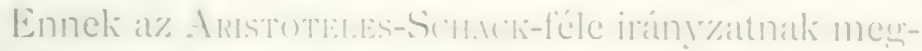

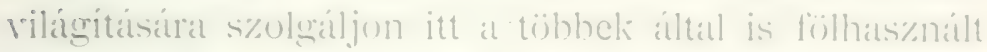

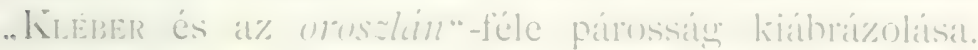

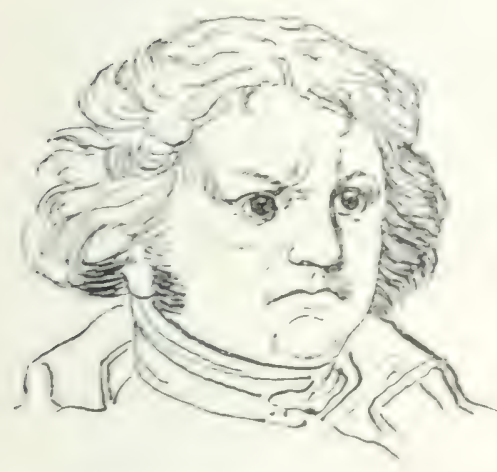

1. Kiléher tảhornok. $1753--1$ s(u)

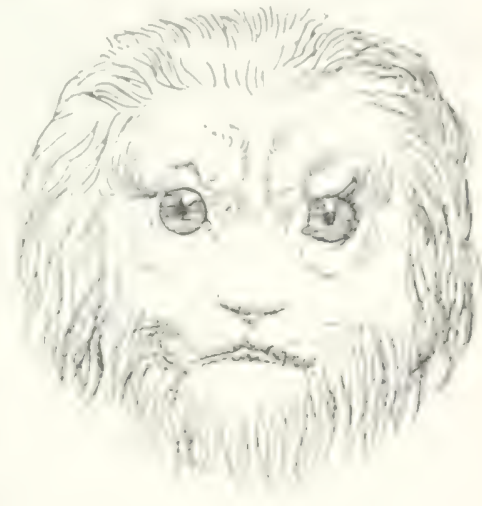

2. Schack oroszlinjin.

ScHack a\% oroszlánt Bupfox nyomén iggy jellemzi:

..Az oroszlán haragja nemes, rettenthetetlensége nagy.lelliúséggel párosult. termés\%ete sensibilis".

KĹÉBER franczia tábomokot 1. Kép azután igy viszonyitia az oroszlánnal:

„Óriás, tagbaszakiadt test: és a midön scajja és szeme a dac\%ot, a rad és féktelen hátorsígot álrultat el, haja pedieg bozontosan és šabadon amyékolita be homlokit, mégis a tübbi nemes vonásat megliontoltságról és nemesséerrö́l tanuskodott, a mely bátossága föbiott uralkodott, azt irányitotta". 
Hozzáteszi Schack, hogy Mirabeau, a franczia forradalom nagy szónoka is, hasonlítván az oroszlánhoz, mitól sem rettent vissza.

Egy pillantást vetve KLÉBER és az oroszlán feje rajzára, - - 2. kép — mely a ScHAck-félének faksimiléje, legott megrgơoüdünk róla, hogy SiH.tek mondásához hiven, mely szerint a szem a lélek tuikre, mindenekelött a szennelet eröszaliolta össze, a nélküil, hogy különben helyes fogalnat rolt rolna az oroszlán fejealkotásáról. szájáról, szeméról, orra alkatáról és sörényérôl. Ha ¿l két fejet hajatól, illetöleg sörény-szöriozetétöl megfosztjuk, ki fog tünni, hogy minden hasonlatosság megraünik, igy tehait a hasonlatosságot nem a ronásoli rokonsága, hanem inkábh a szorözet, illetöley hajzat allostja meg, a mennyiben ez egráltalaban lehetséges.

Különben is mindaz, a mit KLéBER-ról, az elsö

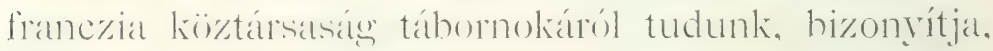

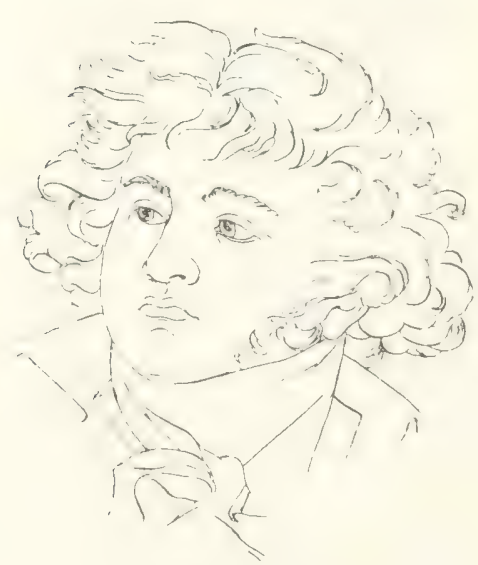

3. Kléber tábornok feje Guérin szerint.

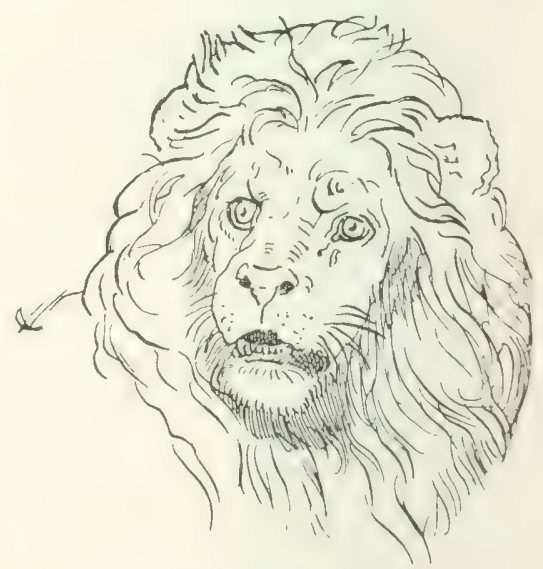

4. Az oroszlán fejc Specht s\%erint.

hogy bátorsága semmiben sem hasonlított az oroszlánéhoz, úgy t. i. a mint az oroszlánt a természet- 
mistoria ismeri. Az oroszlan tud futni, tud fohni is: predifit mentopjar és nem irtozili a\% orozval tamaldistil sem. Kéher menretette a ves\%edelmet, czt kifeje\%te sziljanali metszése: dac\%osan elszínt volt: de nvilt és errenes jellem. A s\%emkiörïn álló merölewes rinc\%. mely a tekintetnek sijtét kifejezést ad. lïébernél nem volt men: a\% oroszlán helyes képén

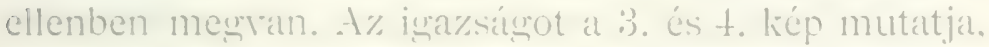
a mely múvészléztól eredre, a viszonyt helyesen tuinteti fiil.

Az Aristoteles-Schack-féle alapon soklial inkább hasonlitható az oroszlánho\% például a már süiketüló BEETHOTEx, a kivel e müben találkozni fogunk.

\section{LAVATER J. C.}

LAVATER J. (..' a X'lli. s\%ázad régén igen nagy zajt ütött fiziognomiai ..tudományával”, mely azonban nem volt az: de a kor ámamlatai kedreztek a\% emberek kiismerését czélzó okoskodásnak és maga GoETHE sem tudtá magát teljesen kivonni a hatás alól. A sok, részben hatalomban levó hivoó, roppant népszerüségre segitette LAlAter-t és e népszerüség még ma is rezers. Leghatározottabb ellenese

\section{LICHTENBERG G. C.}

Lichtexiserg G. C. - a szó legszorosabb értelmében LArater kortársa - - volt, a mennyiben a\% elöbbi $17+2$-ben. a\% utóbbi $17+1$-ben született. LicHTENBERG fömüvében”- tulajdonképen két mondatban foglalja össze birálatát és nézetét. Az egrik ez: ...t pathognomikus - szenredély - jegyek, gyak-

1 Lavaten J. C. , Physingnomische Fragmente". 1775-78. Leipzig - $\therefore$ : ,I:Art de connaitre les Hommes. Edition Moreau". 1807.

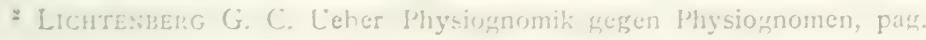

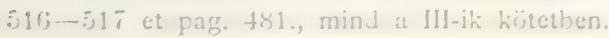


ran ismételve, nem tünnek el egészen, hanem fiziognomiai nyomokat — állandókat — hagynak hátra az arczulatban".

A másik ez: "A múködö szenvedélyeknek vannak jegyeik és tagadhatatlan, hogy ezek nyomot is vésnek; cbben rejlik az, a mi a fiziognomikában igaz".

Ez a felfogás egészen helyes és visszasugárzik a genezis idézett helyére is, a mikor t. i. az ÚR Kár-tól ábrázatjának elváltozását kérdi.

Nem lehet e mú feladata, hogy az irodalom megkïzelíthetö részének fonalán a fiziognomikának, mint tudományos disciplinának ingadozáait lejlödése során kifejtse; messze vezetne és a végczélra nézve nem is lényeges; de érinteni kell

GRATIOLET, PIERRE ${ }^{1}$ Vizsúnalatait, mert ö inkáhb a test-

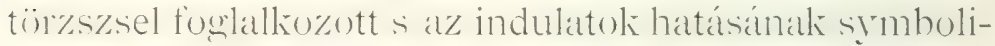
liajat adta. Az tagadhatatlan, hogy a psiche behatásil atatt alló és megnyilathozó testmozgádsok vizscáalata szintén fontos, mert szerves összefügrésben áll részei szerint az indulatokkal és azoknak az arczban - a szihan való kifejezését liegésziti, érthetöhbé, hatásosabbá teszi. A kéró, áldó, visszautasító stb. arczkifejezésisel a kéznek, harnak és a testtörzsnek is mesfelelö mozdulata, illetölegr tartátsat ran, és ebben nemeriak sok az egyéni, de a faji és nemzeti jellem is.

\section{DARWIN, CHARLES.}

Most már átmegyünk DARwis múvére ", nem azért, hogy alapul vegyük, hanem azért, mert úgy-

1 Gratiolet, Pierre: „De la Physiognomic et des Mouvements d'Expression", Paris, 1865.

- DARWIN Ch. ,Der Ausdruck der Gemüthsbewegungen bei dem Menschen und den Thieren. Aus dem Englischen ïbersetzt von Victor Carus. Stuttgart, 1872."V. ö. Henry Hughes: „Dic Mimik des Menschen auf Grund voluntarischer P'sychologie". Frankfurt, 1900. Bevezetó rész. 
s\%óloin esto tételhe foglalhato jellemzésével nyit-

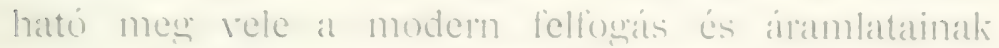
sora. Jint mindenben, ligy a fiziognomibiban is D.MrmIx felfogrisal tökéletesen tudományos és a\% al mit valamely múvével mege akar világitani, lapidáris

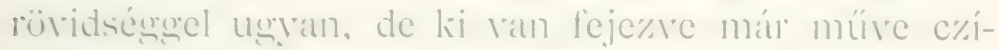
mében is. Ide tartozó müvének czime: "The expression of the emotions in Man and Animals", masgrarul: ...tz indulatok kifejezése az embernél és az állatolnál. legott és tisztán megmondja, miröl van szó Megtudjuk mindenelielótt, hogr noha az emberrel a\% aillat viszonyítra van, e\% nem történile sem - -risToTELES, sem SopHL's ScHAck értelmében, mert D.MrWI. nem a kïilsó tulajdonság vag̣ hasonlatosság, hanem a belsö ingerböl támadó indulat mimikai kifejezését tartja szem elött, mely forrása és eredete szerint embernél és állatnál egýséges. Fzt a\%onban nem állítja a\% általános ember- vagy állattan szolgálatába. hanem erösségeliet lieres benne leszámaztatási tanánali kiépitéséhe\%. Ezen a\% ösvényen valóságros mérhetetlen timomságokhoz juthatunk el, melyeknek stavaliba foglalt meghatározása szinte lehetetlen. Így egyebeli között, hogy minden ember, szakismeret nélküil is. mintegr ösztönszerúleg tudja: mikor örüil, mikor búsul, mikor figyel, mikor harasszik, mikor dühös. mikor fél stb. a kutyá? l'eszi pediğ ezt észre az illetö indulat külsö kifejezéséböl, a mint c\% a psỹchikus. vagyis belsö ingerböl kelve, mimikál alakot ölt, melyet azonban finomságai szerint szavaklial meghatározni aharni, lehetetlen. Íg van az a\% embernél is, nohat ... mint látni fogjuk - ennél az indulatok tüikrö\%ödése és meghatarozása kérdésében már sok történt. Méng ezeknél is mérhetetlenebb finomságokho\% 
jutunk el, ha a hangot vesszük. A kis fitiszmadá

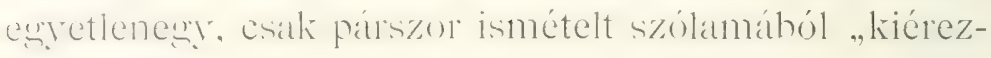
züik", hogy a kis szárnyasnak bánata esett — ezt kiérezzük az emberéböl is!

DARIvix nagy fáradsággal végzett vizsgálatokkal més azt is mesallapitotta, hosy a természetes állapotban élö népek mimikája — szemben a müvelt népeliével - sokkal több közös vonást, mint eltérést mutat.

DARwin müve azonban csak nagyon közvetve tartozik e dolgozat végczéljához; de DARIvin-t mellözni nem lehet, mert mindenképen súlylyal bír és PIDERIT - kire nemsokára reátérünk — müve bevezetésében kimondja, hogy bármit is tartson a kritika DARIrix múvéról, bizonyos az, hogy a tárgy tudományos, beható müvelését ez indította meg.

\section{DUCHENNE DE BOULOGNE.}

Duchenne de Boulogne, egy kitünö franczia anatómus és kisérletezö fényesen kiállitott müve, ${ }^{1}$ DARwin és PIDERiT múvét megelözöleg, tehát úgy jelent meg, hogy a két elöbb nevezett tudós még tekintetbe rehette.

Duchense irányát már a "mécanisme“ szóval jellemzi; de ezenfelüil a bevezetó részben kiemeli, hogy

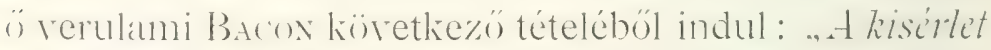
kérdés a természethez, annak megszólaltatására".

Nem figyeli meg az embert, mikor indulatai belsö ̈̈sztionhöl, tehat psychikus hehatásbol kelve, a\% arc\%on tüirözödnek, hanem az így keletkezett, ismert — sokszor azonban csak feltett arczulatokat az elektromosságnak az arez különbözö izmaira való reá-

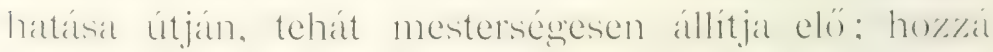

1 DuchenNe de Boulogne G. B. ,Mécanisme de la physiognomic, du analyse électro-physiologique de l'expression du passions". Paris, 1870. 


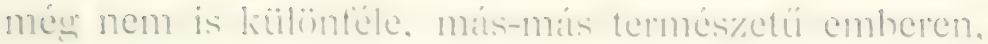

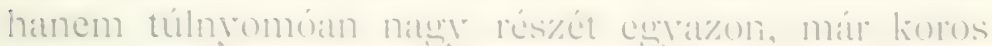

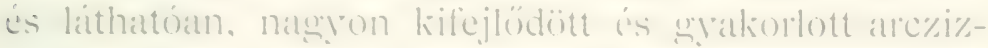

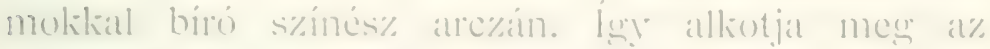

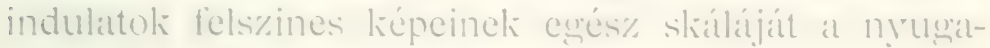

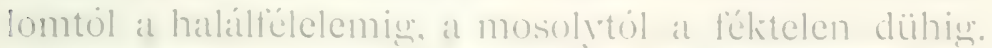

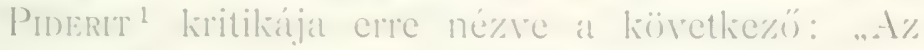
izmoknak e mozdulatai t. i. elektronossiug behataisia alatt - nem belsö, hanem küisö ingerböl, nem sitjit, hanem másinat a a kiscirletezünck akara-

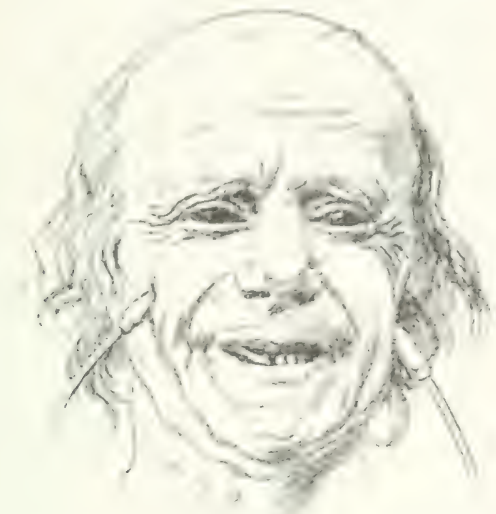

万. Duchenne, a sirás két fiaja eqyazon arc\%on.

tából folynak, azért ily arczintoritúsok — „Grimassen" - keréssel járulnak ahhoz, hogry bizonyos indulatoknak, bizonyos arczizmokkal való összefüis-

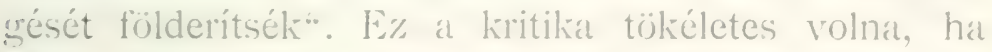
PIDERIT hozzáfüzi ezt: annyival is inkább, mert ugyranaz az indulat a küilönbözö vémérsékiletü eşyének arczán nem egyazon módon és küilönösen más-más fokban tuikrijzödik.

1 PIIEs:IT: ., Mimik und Physingnomik" -. v. ij. 1. jeryzet - pas. (j. 
Az nagyon természetes, hogy Duchense-nek az arcz mind a két fele hatalmában áll és így az arczfeleken más-más izmot téve ki az elektrikus ingernek, a két arczfélnek külön kifejezést is adhat.

Hogy az olvasónak legalább fogalma legyen

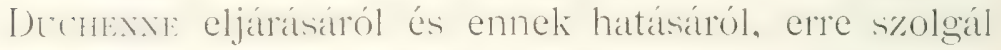
a hajosan megswerezhetö és drágar münek egrili felemis aczulata. 5. kép.

Tisztán látható, hogy a jobb arczfélen a száj fel van rántva, a bal félen nem, ahhoz képest, a mint az elektromosság a kis járomizomra és a felső ajkat emeló izomra is reá hat, a melyeknek megfelelóen a ránczozat és a szem összehúzása is alakul s így a sirásnak két fokozatát alkotja meg. Úgy látszik,

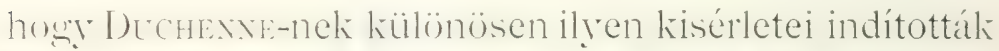

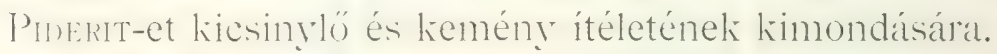

Darmin ítélete Duchense müvéról ellenben ez: ${ }^{1}$ "Duchexve nem bocsátkozott annak bizonyításába: miért húzódnak össze bizonyos izmok bizonyos szellemi behatások alatt és miért nem mások? De mégis kimutatta azokat az izmokat, a melyek legkisebb mértékben állanak az akarat ellenörzése alatt". Be kell vallani, hogy ez az itélet igazán az imponderabiliák legszélsóbb határait érinti.

Ande Duchense múve a mi feladatunkra nézve nagy értékkel bir, a mint ez alább az ú. n. „magyar tipusok: méltatú tárọalásánál világosan ki foge tünni. Addig is folytatjuk.

\section{PIDERIT THEODOR.}

PIDERIT már többször idézett múvének második kiadása - mely itt alapul van véve - szavakban 


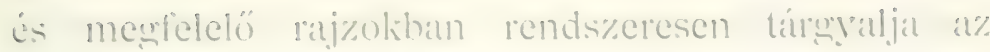
indulatoknak - - de a hajkamoknak és rérmérsćliletnek is - at atrezulathan valo kifejezését; semattikus lépeit pedign, a hol szüliséges, tipikus eyréneli arczképeivel is timogatja. Az utóbhiak között (inethe. 11. Frigres király, Richelieu, Locke, II. Katalin, Jean Paul, Beethoven, Kéber, I. Xapoleon, Luther, Fanklin Johannes Nüiller stb. és ezentúl tübb ókori szobrás\%ati remek, mint Laokoon, Brutus, Nero. El kell ismemi. hogy ez a mimikának és a fiziognomikának elsö, rendszeres liéziliönyre, mert az oliot és oliozatát szerves kapcsolatban adja és nem feledkezik meg a küilsó) behatást köretö ú. n. ösztönszerú mimikáról sem.

Igen szép és jellemzö küiönösen némely részében a mü bevezetése: . Az arez játéka a szellem néma nỵelve. A népeli szóbeli nyelve különbözö és változik ; az arczulat néma nyelve ellenben valamennyi embernél ugyana\%. A radembernél éppen úgy, mint a mürelt európainál. a rabszolgánál éppen úgyr, mint a királỹnál, a gyermeknél éppen úgy, mint az aggnál a hangulat, az érzés, al vágy és a szenvedély egrazon módon nyilathozik meğ. Az arez nyelve oly világos, hogy a gyermek mátr zsenge korában kiolvassa anyja arczábúl a szomorúságot, a kedretlenséget", - - hozzátehetjük, hogy a jókedvet és szeretetet is. .Minden ember megérti a szellem némat nyelvét; megtanulja enpiricze és nem veszödik nyelrtanával. De a\% is igaz, hogy a mennyire felliaroltáli a nyelvek tanulmányozását, épp annyira hanyagolták el az arczkifejezés néma nyelvének mivelését."

„Johannes Mérek az ember élettanáról irott korszakalkotó mürében. ${ }^{1}$ mécg a XIX-dik száizad elsö 
felében is azt mondta: "Az arczizmok viszonya bizonyos senvedélyekhez teljesen ismeretlen". Belu, Oken. Huschki. H.1Risis még mindign hizonytalansághan tapogatódznak s így tart ez DARWIN-ig, ki azonban csak azt veszi, a mi tanát támogatja; a tárgy tudományos felfonsisit és mivelését azomban talgadhatatlanul ö indította meg."

Piderír felfogása szerint —éppen úgy, mint ScHACKnál is - az arcz mimikájában a kifejezés legfóbb szerve, igazi „organum principale“, a szem, és minthogy fejtegetéseink rendén, lényeges oknál fogva, ugyanerre a szervre kell a legnagyobb súlyt fektetnünk, már itt adjuk azt, a mit PIDERIT a szemre nézve mesuallapit.

.. Vargon kellemetlen hehatásoknál, külünösen akkor, hat azok hirtelenségrel kiovetheznek be, a szem erósen hungorit: de ily behatátsoknál csiak rithán zílul egészen és tartósan, azért, mert a szemen át kapcsolódunk leghensöhhen a külvilághoz és éppen ezért a szem teljes hehunyásal rendén elreszne annak lehetösége, hogy önállóan fölismerjünk, cselekedjünk, a mi pedig a veszedelemmel szemben tehetetlenséget jelentene."

„Minden hirtelen támadó behatás, mely a látást éri és a szennet esetlegr reszélyeztethetné, azonnal és villám-

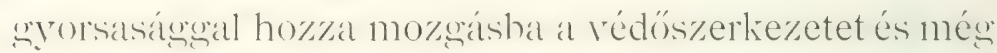
mielótt hogr a reszedelmet helyesen feltoghatnók. a rédelemröl tudatosan gondoskodhatnánk, e\% a heeses szerv már, mintegy ösztönszerúleg, védve is van."

„Ha a szemet hirtelenuil támadó, vakitó fény éri, a s\%em rendesen nem zárul he esésesen, hanem a homluk

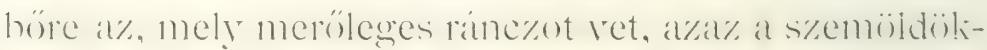
izmok - összerántó - megfeszítésével elóliészíti a s\%em hehunyisit. I meröleges homlokrancolihan tehat 


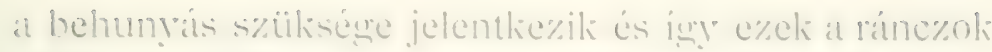

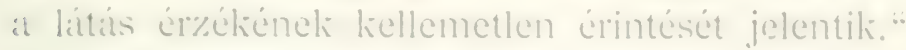

De jelentenck mats olibul matst is!

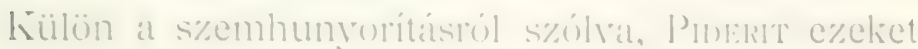

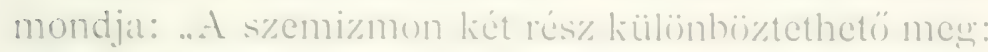
esy belsö, kï̈ponti es esy kïilsö, kïj\%eti: mindlietti liulön-küilön mozâathatú. A humvoritásnál a belsö, kiöponti izomrostok mo\%dulnak meg s e\% valgy tudatosan. vagy ellenkezöen türténik. A szemet behunyhatjuk. a hányszor crak akarjuk: de aliaratunkon kivül is bezúrul, még pediọ :

1. A müri érintésnél:

2. A hirtelen, crös látási behatátsnál:

3. A hallást erósen érö ingeichnél."

Naygron jellemzó, helyes és e mü régezéljaira nézve fontos az, a mit PIDERIT a mimika és fiziognomikal hözütti szerres hapesolatról mond, a mint köretkezili. ..Fiziognomiai jegreliet esak azokon a részelien kereshetünk, a melyek a szellem múliödésének hatásat alatt állanak. - E\%ek különösen a\% izmok és e\%ek között különösen az arz i mai. Ezeknek a\% izmoknak futólagos, mimikai mozgásai, soliszoros ismétlés rendén, fiziognomiai ronásoliká alakiulnak, vagryis állandó - habitualis — jegreliké rálnak: "

Ha figrelembe resszül a\%t a\% irányt, a melyet at mimikára és fiziognomikára nézve eddigg jeleztünk. csak természetesnek fogriuk találni, hogy a beliovetliezett haladás az élesebb meskiülïnböztetéseli és tüzetesebb meghatározások terére lépett. És valóban LoMBroso Cizar a rendellenességet felé fordult, míg MANTEGAZZA PAOLr) inkább a normális jellegeket vette eló. 


\section{LOMBROSO CÉZÁR.}

Lomibroso inkább szellemes, mint rendszeres. De éppen elöhhi tulajdonságúnál fograra sol meshatározátsal

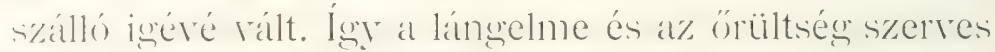
rokonságáról szóló. Ö abból indul ki, hogy a gonosztevö mint olyan születik és hogy szervezetének, különösen fejének, alkotásánal fogra a\%. Ehböl a\% elrböl indúlva ki, megállapítja a jellemzö jegyeket.

Fömüvében ${ }^{1}$ a legfóbb jegyeket így adja :

A született gonosztevö.

Füile. elálló.

Haja: tömött.

Szakálla: gyér.

Homloküregei : boltozatosak.

Állkapesa: roppant.

Pofacsontja: széles.

I gुgilkos.

Szeme: rérbenforgó, üreges, jeg̣es, merer tekintetü. Orra: nagy, sokszor sas vagy héjjaorr.

Állkapesa: csontos, erós.

Pofája: széles.

Haja: göndör, tömött, sötét.

Szakálla: gyér.

Ajaka: keskeny.

Szemfoga: nagy.

Álmatagsága: -- nystogonus -... gyakori.

Elöfordulnak még

Féloldalú arcóngatás, vigyorgás, fenyegetö foyvicsoritás úg, hogr a szemfogak láthatókiá valnak. Fiile: mindig elálló.

${ }^{2}$ Lombroso C.-Fränki M. O. „Der Vorbrecher - Homo delinquens - in anthropologischer, aerztlicher und juristischer Beziehung. "Hamburg, 1887-90. 
De Immbruse s\%erint at nemes arc\%ú sa\%emberek sem rithik: ilyenek voltak: Lateenatire, Bonchet. Sutter, Golatrdi, Jaleorone, Malatgutti és másoli.

Howy milyen eljuts sorin. a\% nem tartozik ide. de Lombroso eljut at unonoszterö)-tipus liét esoportjának felállitásidy. a melyelet a jellemzö jesyek s\%erint ing ostályo\%:

\section{I:I-11 ci-opast:}

Roppant állhapocs.

Gyér szakíll.

Tömött hạ.

$$
\text { Második csoport: }
$$

Elálló füil.

Hátraszegett homlok.

Làncsalság.

Görbe orr.

A szem jelentöségére nézye jellemzó az, a mit Lomiroso a hirhedt I'inoca-ról jegyzett fel élt 1775 -töl 1857-ig — ki kalandos életet folytatrá, tolvaj. gályarab, hirhedt rendörkém rolt és azt mondta, hogy ..egyetlen jól kilesett pillantásról biztosan fölismeri a gazembert".

A rendes - nomális jelenségeliet s\%éles alapon

\section{MANTEGAZZA, PAOLO}

tárgyalja. ${ }^{1}$ A tulajdonsággoliat részben GHirardeut.l és mások alapján íg! osztályoz\%a:

Tad: a tobas, pampa, maori, riti.

Szelid: a chiriguano. grabáana.

Apatikus: a patagon, amara stb.

Konikus: à néser.

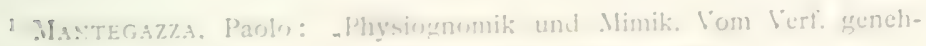
migte lehersetzung von k. Löwenfeld 1., II." l.cipzis, 1s!m!. 
Buta: a hottentotta, ausztráliai.

Intelligens: az európai.

Tïzetesebben meghatározva ezeket adja:

Egyiptomi: ravasz, zsugori, buja, de tanulékony és ügyes.

Thrák: alattomos. lusta.

Szittya: kegyetlen.

Gall, a transalpin: nehézfejü, durva, büszke.

Olasz: kiváló a tóga nemességétól (ez egy kissé „laus propria“).

Görög : élénk.

Sziriati: zsuguri.

Ázsiai : fajtalan, buja.

Spanyol, Szicziliai: tüzes.

Portugál: melancholikus, de sanguinikus is; eröteljes, de nehézfejú.

Német: flegmatikus, de cholerikus is; nagy és együgyú.

Franczia: fiegmatikus, cholerikus.

Svajczi: ezt csak a myilt tekintet jellemzi.

Zsidó: hadaró, kapkodó, kurtán végező. Lexz szerint aránylag több epével bír.

A mi a testtartás, mozgás jelentőségét illeti, itt Mantegazza Fuesslix nyomán a következóliet adja:

"A tartás és mozgás minósége sokszor élesebben

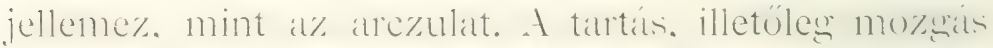

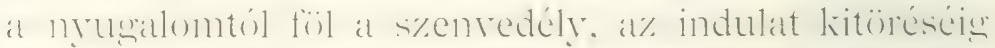
oly jellemző lehet, hogy a magyart — szószerint "Hungar." - szlávot, illirt és oláhot a testtartás tisztes voltából - Anstand, — a fej hordozásából és a tatejejtisholl lehet felismemi is jellem s\%rint is os\%titlyozni." 


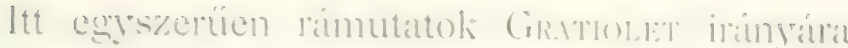

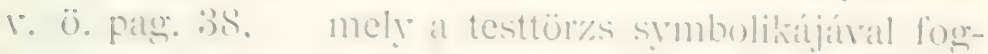
lalliozott.

Amnak menfelelóen, hogy at\% európatit ,intellirens"-nek osztilyozta, fejtegetéseinek során a\%t is hoz\%ateszi. hog! Europar lï̈lönbözö) népeinek mimikáijal elsö sorban a leskiválóbb lelki psịchilius saljatossígrolitól ered.

Ehhe\% liépest Európála nézre liét csoport alakitható. Ł́. m.:

Expanziv mimikája van a\% olas\%, franc\%ia, s\%lá és orosz népnek.

lionezentrikus a német és a skandinál népnek.

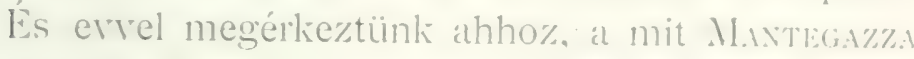
a szemról mond:

. Úgy a\% igaz, mint a šinlelt ér\%elmek mimikálja legrégül abba szorul, a mit a .lélek tïkrének" nevezünk, ez pedig a szem" . tehát éppen úgy, mint Schack és Piderit”. Mikor látszólag mál minden mimikái kifejezés elsimult és azt hinnök, hogy a teljes nyugalommal ran dolgunk, mintegry összefoglalla

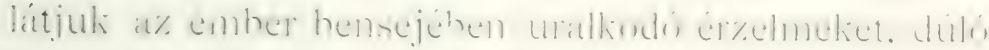
indulatokat a szemben. Ezt a\% éles megfigrelö nem is téreszti el." Tálán nem is kell itt kïlön reámutatni linoce imént felhozott állítására.

MA.NTEGAZzA-nak itt kifejtett sorozata al köretkezöben tetöz és ezt immál képhez kiötjük:

Az intellektuális energiának két legriválóbb képe:

1. As alkotó képselö erö, 6. kiép.

2. A kutató gondolkozis, T. liép.'

A képzelö erö kifejezésénél mindazok at mozzat-

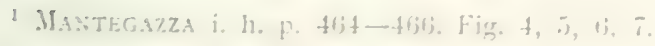


natok, a melyek a szem és száj központjában tetöznek, az arcz periferiája felé kisugárzók, tehát centrifugálisok. 6. kép.

A gondolkozó arczkifejezésnél ellenben a mozzanatok az arcz közepén a szemre és szájra nézve összpontosulok, tehait a centrifugálissal ellenkezók. $テ$. kép.

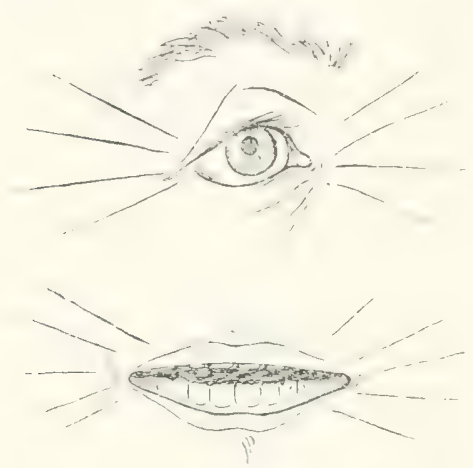

6. Mimikai központ: „Az alkotó képzelö erô kifejezóje."
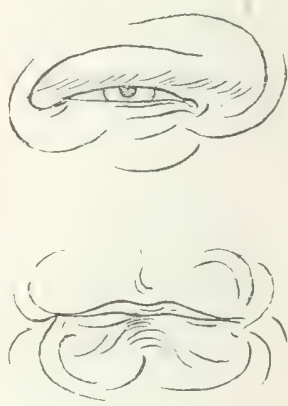

7. Mimikai központ: "A kutató gondolkozás kifejezôje."

Az inspirált ember létén kívül, a nyilt szemhatáron keres; a gondolkozó mintegyj önmagába fordul.

A képzelödő kifejezés soliszor átcsap pathologiai alakzatokba, ilyenek a lelkesedés, a költöiség és fel az örületig.

A gondolkozó kifejezés, ha túlhajtásba csap, át-

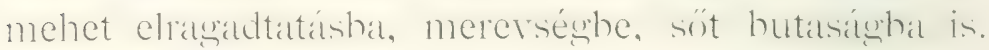

Egyáltalában a mimikában a végletek törvénye

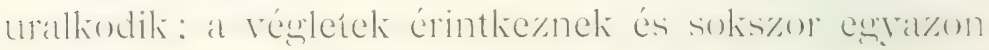
színben összefolynak.

Maxtegazza szerint tehát az arczulat mimikai

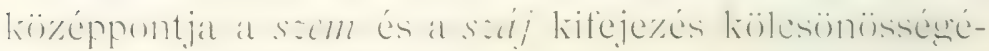
ben nyilatkozik meg. 


\section{HUGHES HENRY.}

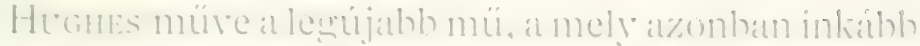

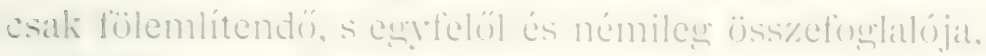
másielól elméleti es höleseleti kifejüje a mimikáról

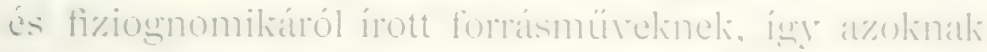

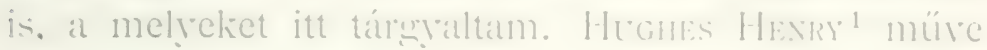
az ember mimihifúról szúl al .. voluntarius lélektan" alapjín. mely a liözönséseres lélektanho\% oly vis\%ony"ban áll, mint a CARTEsils-féle alaptétel clvilto\%tatásat

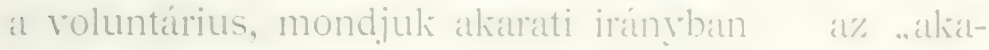
matos" t. i. kétértelmúi volna.

Az elváltoztatás ime ez: Cintesic's tétele, mint végsö foglalatja az emberinek: ..engito, ¿rso sum". azaz: ..gondolkozom, telut v'usyok" : voluntáriusan elváltoztatra, vasg módosítra: .. zulo. ergo sum", azaz: .gondolkozom" helyett .akarok. tehit z'asyok".

Ennek kifejtését azonban mégr megelöri egry hijltemény. mint rilágos bizonyitéka amnak, a mit. at kiindulást keresve én is hangsúlyoztam, hogry a szalialdatlan összefügrgést, a continuitást csupán a lélektani viszonylatokban találhatjuk - a fajiakban. vagy történelmiekben nem. Ám álljon itt két jellenzö rersszak:

Als durch des Allmächtiren Arm

Bahels Turm in Schutt zerstohen,

Hat ein unzähllarer Schwarm

löliersprachen sich erhohen.

Gleich, nur eine sprache blieh

Allen Zeiten, allen Läindern:

llie auf der (iefüble Trieh

lonste Nienen sich vurändern.

\& Hernes Henry: Die Mimik des Men-chen auf Cirund voluntarisclier

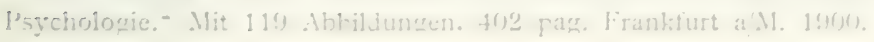




\section{Magyarul :}

A midón a nagy Úristen

Bábel tornyát összetörte :

A népnyelvek áradatát

A világon szétsöpörte.

Csak egy maradt érintetlen,

Es ez ma is uralkodik:

Az, mely belsônk ösztönéböl

Az arczunkról sugározik.

Az egész kötött formában, de bizony csak halavány kifejezése annak, a mit PIDERIT, tudásból indulvá. oly szépen fejezett ki - 1. pag. 43, - a midön az arcz játékáról, mint a szellem néma nyelvéröl szól.

Ezenkivüil élesen jellemzók az -elószó következó részei: "A jelenkor a tett ideje. A míg a XIX. század elsó) fele a s\%emlélödésnek hódolt, addig a második fele erélyes cselekrésre késztetett. Azelött a múvészet és a bölcselem uralkodott a szellemeken, most a technikáté és az orvostané az elsöbbség, a fölény. E\% a változás Európának valamennyi kulturnépénél köovetkezett be, leginkább azonhan Németországban, hol egykoron GoETHE-ben a\% oly magasia becsült Ideail - eszmény - jelent meg, manapság azonban Bismarck, mint el nem ért példa - Vorbild — áll elöttünk".

„Ugyanennek az átalakulásnak a lélektan is alá kell hogy vesse magát, mint a mely a szellem tudományának alapját nyujtja . . . hiábavaló minden

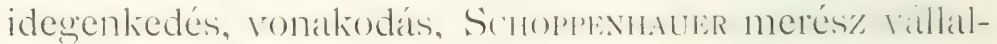
kozása után már csak idó kérdése, hogy mikor tér át a lélektan értelmi — intellektuell — lelfogásától a voluntarius irányhoz". 


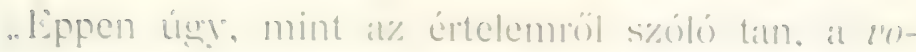

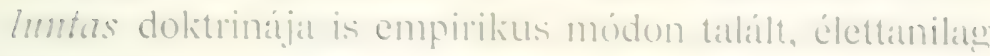

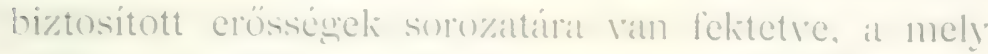

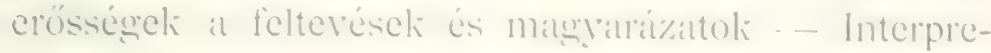

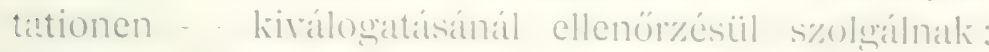
a tulajdonképeni analizisek és deduke\%ióli, termés\%etesen mindig a\% ünönmegfingelésböl vétetnek".

Ha al könyrben letárgalt kategoriak bizonyos sorozatait ilitatom ide, meg. fogunk grö̈\%ödni, hogy a könỹr egy adott nép jellemzö atrezulatának mexhatá-

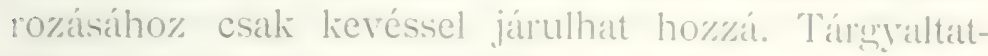
nak a\% ellenszenv, a\% undor, a tis\%telet, a félelem, a granalivás, a figyelem, a felháborodás, a s\%em meresztése. a szájtátás, a gond, a borzalon, a kegyetlenség, a vidámság, a lieserúisége, a fennhéjázás, al gúny, a csók, a mosoly, a nevetés, a megretés, ‘\% irigység, a fütyülés, a liöpés, al nyclés, a büs\%lieségr. a rosszakarat, a sírás, a düh, a haray stb. stb.

A tárgyalás nem összehasonlító, sem nem a\% egyazon belső ingerböl támadó okozatnak személy de sokszor nemzet - szerint való kiülönbözö meğ-

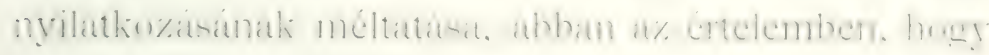
p. o. a féktelen düh vérmérséklet s\%erint a\% egyiknél felorditással, fogricsorítással, az arc\% összes vonásainak feldúlásával, a test féktelen mozdulataival járhat. mely körmölésben, harapásban, fojtogatásban tetözhet, - mig másnál csak a s\%em bešél, vérben forog; a testtörzs nyugodt; a kitörés pedig al, hogy at kéz tört ragad és belédijti áldo\%ata, a\% okozó, s\%ivébe : fejszét, köret ragad és egy csapással sujtjat agyon azt. a ki az okozó) a vakdühben azt is, at ki éppen Litjába keriil -

Hogy különösen a s\%envedély, à indulat nemesak 
kïlünhüzö egrvéneknél, hanen népeknél is küilönbözöen nyilatlozili meg. més pedign mimikatalg is, igg tehát mindez alkalmas arra, hogy az egyén és az egész nép arczulatában allandó, tehát jellemzó) ronásoliat teremtsen, az bizonyos.

A midön még megjegyzem, hogy Hughes minden

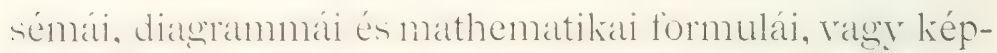
letei mellett is sokszor lényeges anatomiai viszonyok meshatairozádiánál igen nawgrokat botlik, mint p. o. abban. hoygy a kïnnyed mosolynál némelyeknél az orczán kép-

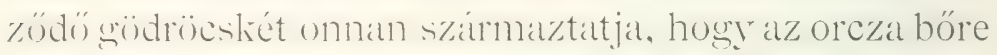
a järomcsonthoz (!) hozzánótt, ${ }^{1}$ holott az, a mint

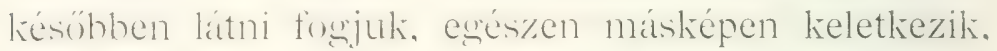
illjon més itt az is, howy a liépel legnagrobb része Piderit-böl van véve s hogy felhașználja a Borée 2 féle mimikai arczlépeliet is, a melyek azonban nem az arc\%nak belso", érzelni ösztionhöl eredó elváltozátsát ábrázolják, hanem igen fejlett arczizmokkal bíró és rendkivüil saraliorlott szinés\% arezának mondracsinált kifejezései: mint ilyenek pedis hizonyos tekintetben alatta állanak a Duchesse-féle arczoknak, mert teljesen egyéniek, holott Duchexxe elöre jelzett izmok elektromos ingerlésével hámely egón arczán azonos kifejezést tudott teremteni, ha a fokozatban nem is,

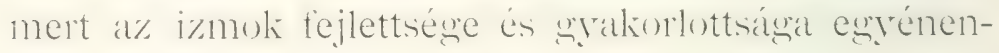
ként különböző, de lényegben mindenesetre.

Evvel bevégeztük azt, a mit e könyv végezéljára nérve történelmi szemponthol elmondani szülisécersnek tartottunk.

1 Hugnes, p. 350. "... bisweilen tritt ein Wangengrübchen auf wo die Haut an das Jochbein angenachsen".

" BORÉE, „Physiognomische Studien“ Stuttgart 1899. 


\section{AZ AXATOMHA KESEEO}

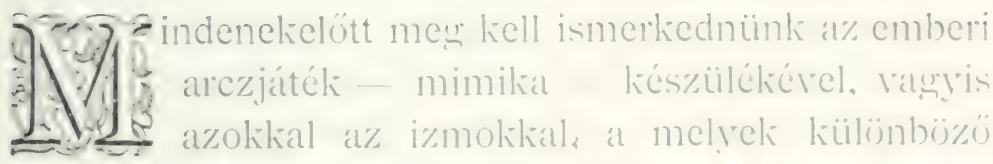

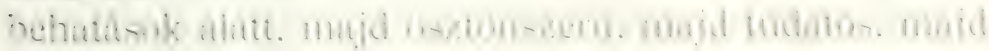
visszaható mozgást végève, mint okok okozatai a\% arczkifejezést alkotják meğ: kizálásálval azokinak, at melyek mesterségesen - Dechexxe - vagy syaliorlás útján, mondráa támadnak - BORÉE.

Ezeliet az izmokat teljes egrensúlyban, terékenységrben és azokban az elváltozásokiban kell némileyg megismernünk, a mely utóbbiak allandó arczulati jegret ragy jegyeket alkothatnak vagy alkotnak meg.

Az Izirok magrarázatát arval kell megelöznünk. hogy a szerzók a beosztásban és megnevezésben nem egrybehangzól. Jağyban és egészben PHintr és Dechexwe összeállítását kijretjüik. A\% eredményt a S-dik kép tünteti föl, a magyaráal pediśs ín e\%:

. 1. Homlokizom.

li. Szem körizma. felsö fél.

i. Felsó szempillá

1). Alsó szempilla.

l: Szem köjrizmat. alsó fól.

I: Járomizom, kisebb.

1. A felsó ajak tulajdonképeni emeló izma. 
H. A felső ajak és orrczimpa közös emelő izma.

I. Nagy járomizom.

J. Neretö-izom. ${ }^{1}$

K. Száj kürizma.

L. Háromszögizom.

M. Szemöldök-összerántó izom.

$N$. Gula-izom.

O. Pallóizom.

$P$. Orrczimpatágító izom. ${ }^{2}$

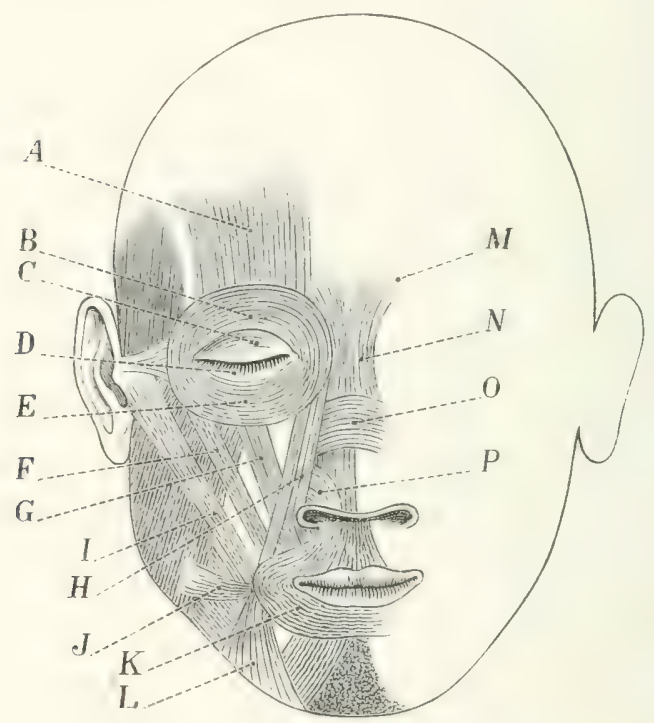

8. Az emberi arcz mimikai készsége.

1 Piderit-nél, i. h. fig. $5, h$. : szöveg pag. 121. sub. ${ }_{n}$ Schwiichere Grade des Lachens". Mihalkovics-nál: "Leiró emberboncztan" : mosolygó-izom.

2 A tudományos elnevezés szerint: A. Musculus frontalis. B. M. orbicularis palpebrarum, pars superior; C. Palpebra superior; D. Palpebra inferior; E. M. orbicularis palpebrarum, pars inferior; F. .I. zygomaticus minor; G. M. levator proprius labii superioris; $H$. M. levator communis labii superioris et alae nasi; I. M. zygomaticus major; J. M. risorius K. M. orbicularis oris; $L$. M. triangularis; $M$. M. corrugator supercilii; X. M. pyramidalis; O. M. transversalis nasi; $P$. .I. dilatator alae nasi. A magyar elnevezéseknél, e könyv természeténél fogra a közérthetöségre törekedtem. 


\section{MHALKOVICS.}

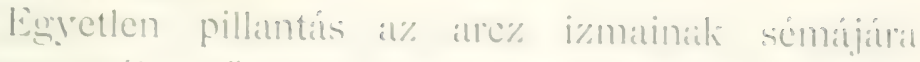

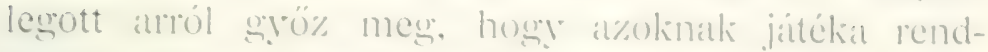

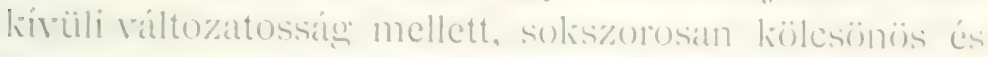

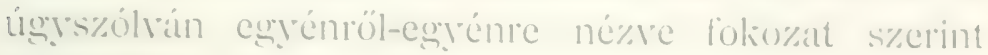
modositható.

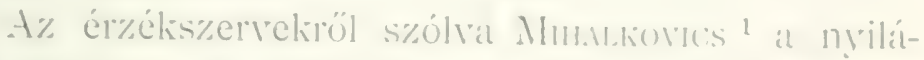
sok körüil levớ izmok szerepét érinti st ittép a\% arczizmok játéliara is: . A arezizmoli a homlokizommal egryüt, a kedélyhangrulatot és a szenvedélyeket fejezik ki s az arczjaték mimika töliali füge. Hogy ez annyira változatos és eguénileg jellemari. annali oliát az arczizmok válto\%ó fejlettségében és régzödésük finomabb riszonyainak eltéréseiben kereshetjük. Nevetéskor és siráskor minden embernél ugryánazok a\% izmok múliödnek; de a finomabb ámýalattokban rendkívil sok a változat".

Ezekben à jól megfontolt és éppen àćrt mess\%evágó szálvakban azután közretlenüil a\% is benne ran. hogy a mürveltségi fok, a vérmérséklet s a jellemet alakitó összes viszonyoli hatása, egyénröl-esyéne. de nemzetröl-nenzetre is, árnyalat képében észrevehetö és kifejthetö.

Lássuk azonban, hogran osztályozzat mükiodésüli szerint az arcz izmait Ducheswe.

Az elektromos áramnak kitéve - - tehát nem természetes, bensó ösztönböl - megteremti :

4. a homlokizom: a figyelést:

B. a s\%em körizmának felsö fele: a megriadist:

I) I a szempillák izmái: a mesuetest.

L. a s\%em körizmának alsó fele: a joíliaratot:

1 Mhalkoves (ieza: Ieciri umberbrneztan, p. (iz:). 
$F$. a kisebb járomizom
$G$. a felsó ajakemeló izma a sirást:

I. a nagy járomizom: az örömet;

L. a háromszögizom: a szomoríságot;

M. a szemöldökizom: a fájdalmat;

V. a gulaizom: a támadó indulatot;

O. a pallóizom: a bujaságot;

$P$. az orrczimpa-tágító: $a z$ iszonyatot.

A mint tudjuk, Duchenve mesterségesen előidézett arc\%kifejezćseinek inkáhb csak sematikus értelme és értéke van; a séma próbaköve, tehát értékének meghatározoja a természetes alapokon, belsö ösztönböl alakuló arczkifejezés.

\section{KISÉRLET.}

Tegyünk itt ezen a helyen egy kisérletet az arczjátél egr szörerényesehb formájának megfejtésével.

A gula-, homlok-, szemöldök-, szemkörizom, a szaj kinrizmálal és az ajakemelörel ̈̈szejátszra, az

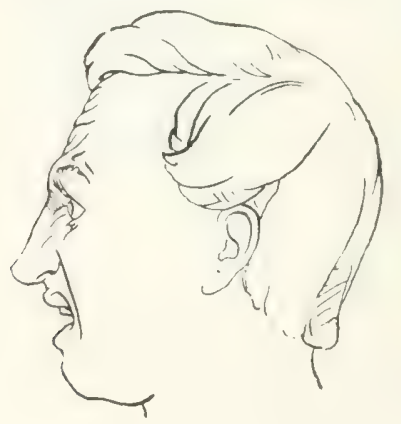

9. Az iszonyat.

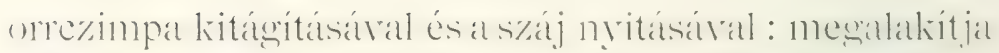
belsö ingerböl, tehát természetes indulatból kelve, az iszonyatot kifejezö arczot - 9. kép. ${ }^{1}$ - De bizonyos 
a\% is, hogy a hatei ero ar idewends\%eren at nem-

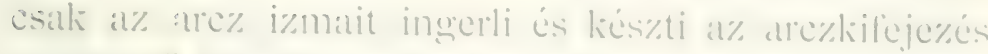
megtelelö alakitásitra, hanem al hatats matshan is meonmyilathozik: a\% is\%ongatt hangen is ad, soit hi\%onyos paralitilus allapotba ejti at egés\% testet, melyneli

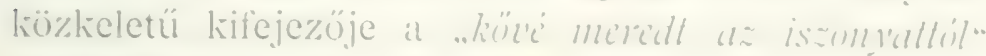
milgyar mondás.

\section{LEONARDO DA VINCI.}

Ha tehát Ducherae mesterséges eljairisálval at\% iszonyatot csak az orrezimpát tágritú izomhoz kiiti, e\% elégtelen, mert PIDEriT szerint s ezt mál at (1-iki képre retett egretlen pillantás is hiveheti a\% is\%onyaat kifejezését alkotó mozzanatok rendkivüil s\%ïve-

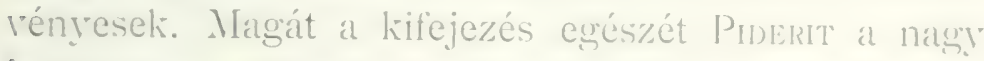
Leonardo da ViNeI ${ }^{1}$ szavaival adja, a mint liöretkezik: ..t legrürrteket, megrerteket, a rendetlenségbe hozottakat halavány arezczal, felhuizolt szemöldökkel lessétek, melyeknek köze s a fölötlïk lev'i" his tele' l'gy'en rinczokkal; az orrlyuk tája kivülröl néhámy ránczczal, a melyek a szen kezdeténél végzödnek. Az orrỵukak - - illetöleg czimpák - - mint a mondott ránczok okozói, föluetve legyenek s az ivalakbun felluizott felsö ajak láthatórá tegye a fogakiat, a melyek ¿z alsóktól távol állyád, a legrürüittnek panaszos kiailtását jelezzél-".

A nagy mester leirása fedi a (1-ik képet, igy lehetöré teszi az illetö arczizmok meshatározását, at mint ezt fentebb láttuk is.

A többi mozzanatot, mely az iszonyattal járvál. nem az arczon folyik, DArme i. m. " isy adja: ...t sziv gyorsan és erósen huzódik össze, úgy, hogy

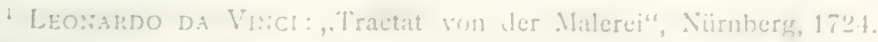

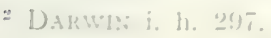


a bordákhoz üitódik. A bör halaványnyá lesz, akárcsak az elajulas kezdetérel, alkalmasint azért, mert a\% idegközpont, a mely az edénỹidegzetet befolyásolja. oly mértélihen ingerelve van, hogr ennek köretkeztéhen a hör kis élöerei összehúzódnak. ( sodálatosképen a hideg börön hideg veríték is kitör, a mi annál küiönösebb, minthogr a veriték-mirigrek akkor szoktak múködni, mikor a bör meleg. A bör szórözète fölmered s a felület izmai reszketnek. A sziv megzarart múkiodésérel eģrberág a lélekzet meggrorsitása is. Esrrike a legjobban kifejezödö mozzanatoknak: valamennyi izomnak a megrázliódtatása. Ez okból és a száj lisizáradásisa folỹtán a hang rekedtté, bizonytalanná válik, vagy el is veszhet: Obstupui, steteruntque comae et vox faucibus haesit".

Tisztin és világosan kivehetjül ezekböl, hogy az esretlen kitétellel „iszungyt" kifejezhetó, az arczon kiválóan és élesen tükröződő mimikai kép csupa ¿̈sszetartozó, egrmást kölcsönösen kiegrészítö mozzatnathó! áll, melynek şöliérzete a szervezet egészébe is terjed. És könnyen belátható, hogy a könnyen iszonyodó egryénnél az iszonyat bizonyos jegrei állandó nyomokat is hagyhatnak, tehát arczulatiakká fiziognomiaiakká -_ válhatnak.

\section{A SZEM OSZTÁLYOZÁSA.}

Mielött néhány arcz elemzésébe fognánk, szük-

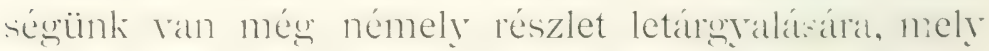
a mü végsố czéljára nézve igen lényeges.

Ezek között elsó sorban áll a szem, mely, mint tudjuk. a szerook esgbehangzó itélete szerint ... lilek iiikre".

PIDERIT többször idézett müvében így osztályozza a szem pillantását: 


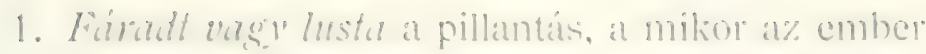

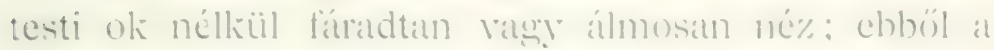

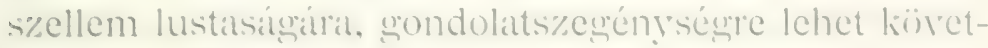
keztetni. PmEnT ennél a meghatálozisinal esupán at hatairozott ok okozatat tartja s\%eme elött. a midion rámutat arra al körülményre, hougy a legécénliehh szellemü ember is lehet fálradt, almatagn vasgr lustat tekintetü - ha nem érdeklödik vary éppen unatkozik: ekkor, Zmmbrmaxx' ${ }^{1}$ szerint: ..1)er weiseste Mann sieht gerade so aus, wie ein Dummkopf, wenn er Langeweile hat" _- magyarul: A legbölesebb ember is, ha unatkozik, olyan, mint a filkó. In e\% a meghatározás esak a mimikára vonatkozik: a reánk nézve fontosabb állandó viszony, az arczulati - fiziognomiai - másképen alakul. Mi magyarok, kik sok.

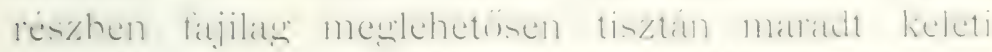

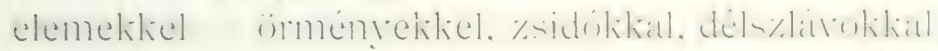

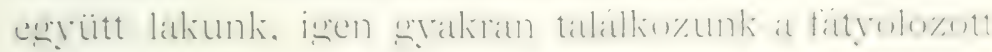
pillantással, mely különösen a sémi tipussal sokszorosan együtt jár - 10. kép - s a melynek jellem-

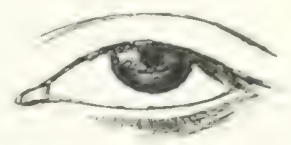

10. A fiatyolozott pillantis.

zése a következö: a szem kiválóan šép, hosszúkás

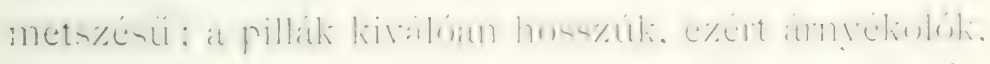
selymesek; a szem fejérje a szemesillag alalt is látszik, maga a szemesillag ellenben, majdnem fele atméröig, a felsó pillar alá van bevonva. A s\%em telintete látszólag fáradt, révedezö, bánatos, epedö; hat at 
jellegek fokozottak, akkor a szem álmos benyomást tesz, sokszor oly mértékben, hogy az álmosság másra is úgy átragad, akár csak az ásítás.

2. Az élénk pillantás: „A ki különös ok nélküil, közönségesen gyors és élénk tekintetet vet, a szemét élénken ide-oda veti, az élénk szellemü“. A pillantás e nemének íbrizolására elégréges a teljesen rendes szem képe - 11. kép - mely, kissé jobban nyitva,

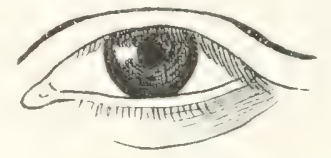

11. Rendes pillantás.

úgy azonban, hogy a szem fejérje sem a szemcsillag fölött, sem alatta ne legyen látható - s a szem élénk járása mellett, jól kiadja az élénk szem élénk voltát, míg abban a helyzetben, a melyben itt rajzolva van, kiadja Piderit harmadik faját:

3. A szilárd tekintetet. "A kinek tekintete átható, szilárd, vagyis a kinél a szemgolyó izomzatának mozgásat sajátusan feszes: ar erélyes at cselelivésben. a gondolkozásban, vagy mind a kettöben is. Ilyen természetü szeme, valóban klasszikus formában,

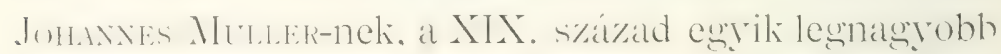
tudósának volt, ki átható tekintetével ,kinézte“ elöadás közben a hospitánsokat". Ez volt tekintete DEÁk Ferencz-nek és Lord Derby-nek - 1799-1869 - is. hozzá kell azonban tenni, hogy a szilárd, átható tekintetnek allioté jarulékia a s\%emkïz merölezes rainczozata és a szemöldök ívezete is, a mint majd ki fixg tünni.

4. A szelíd tekintet. Leginkább a nónemhez van

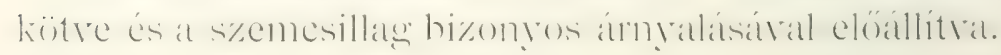




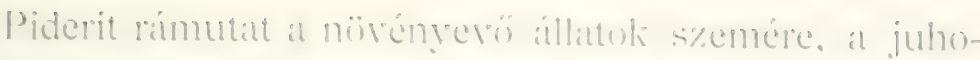
kérat, a teheneliere, hoz\%atehetjük a\% äzstltict, s\%allats-

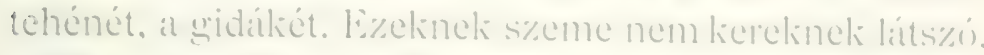
mint a\% átható telintetü rasudatoólié, hanem a felsio pillat

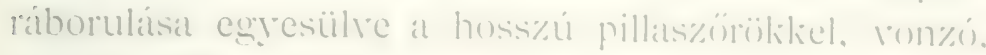

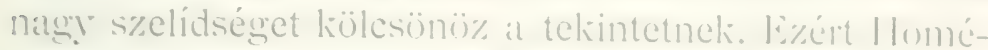
rosznial a szelid telintetú Juno istennö: ...josiss:tehénszemü̈".

5. At kalundozoi tekintet-nek rendesen erkiilesi alapjia van: a könnyelnuúség jellemzöje.

6. A numgtalan tekintet, mely bujkail, megr nem

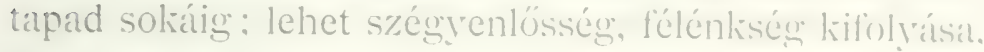
de a gonosz lelkiismereté is: nem tekintwe azt, howy betegség köretkezménye is lehet.

KAULBACH.

Liegészítésül álljon itt méç a meredezó s\%em - 12. kép - melynek az a jellege, hogy a s\%em

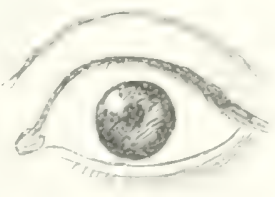

12. A meredezij szem.

fejérje a szemcsillag fülött és alatt is látszik. Mimiliailạ. a legnagyobb meglepetés kifejezöje: patholowialian

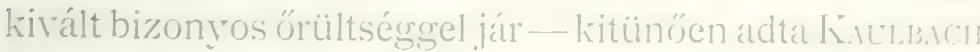
az ,Irrenhaus" egrvik boldogtalanján ${ }^{1}$ : : de más betegségek járuléka is lehet.

A többi tekintet, mint: a titkos, a pedáns tekintet. az elragadtatás, a rajongás tekintete éppen csak megr legyen emlitre, mert csak kevéssé tartorik e müre. 


\section{AZ ORR OSZTÁLVOZÁSA.}

A szem után legnagyobb súly az orra esik, mint a mely az arcz és arczulat megalakulásához, jellemzéséhe\% igen kiváló módon hozzátárul; hiánya a legszebb arczot, kivált a mi európai szemünkben, azonnal visszataszitóvá teheti.

A kiálló és merés\% ivben elötöró sasorrtól a pisze vagy fitos alakzatúign, az atmeneteknek egész sorozata bontható ki; de bizonyos jellemző formák, a melyek a hozrájuk füzödö átmeneteket úgyszólván egybefoglalják, azért mégis felállithatók.

Topinard ${ }^{1}$ öt ilyen törzsformát állít fel, ú. m. a sas-, héjja-, egyenes-, pisze- és külön a sémita orrformát.

Én itt hat törzsformát állitok fel azért, mert a hisos orrnak még nem rendellenes formája, nálunk
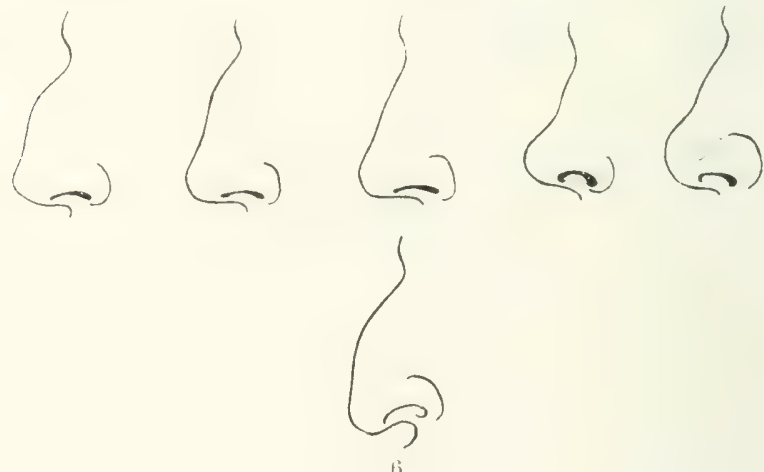

13. Orrformák.

Orrok: 1. sas; 2. héjja ; 3 . eøyenes; 4. pisze; 5 . husos; 6. sémita.

gyakori. Ehhez képest a 13. kép adja meg e törzsformákat a mint következik:

1. Sas; az orrtöben tágas nyergességgel, tompább esúicscsal.

1 Raxkr, Johannes: „Der Mensch", 1887. Il. Band, pag. 43. 


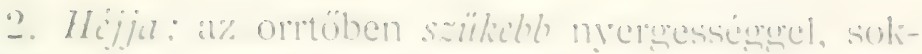

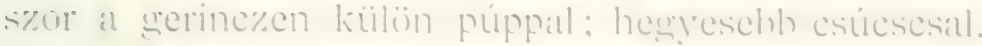

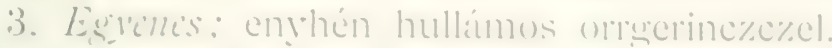

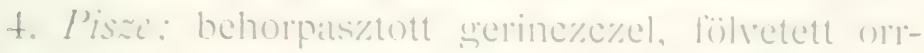
hemingel.

5. Husos: tetemes. tompar omhengyel.

6. Sémita: s\%ükebb nyergességhöl a\%onnal domboruló irvel, mely majdnem, vagy elébe is vilu a heryek.

A mi a sas- és héjju-orr küilönbségét illeti, a mennyiben ezt a liét formát igren grakran ijss\%e\%atvarják, meghisértem itt a tisztazitst, mert mind at liettö at magrarságnál nem ritha.

Amennyiben a liét elnevezés madaralirisl van vére, adom a sas és a héjja csöréneli. népiesen

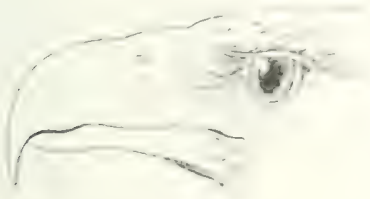

14. 1. sas lieje: 2. héjia inje.

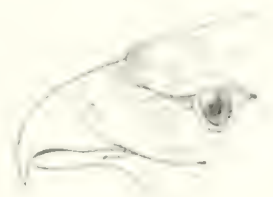

orrának - pontos rajuát és hozzáfüzöm az ornitholorriai jellenzést is.

A sas csöre = orra, tijvétól fográa egyenesen indul

14.1. és esak a vége felé honyul le íres hampróban: az egyenesen talo indulas megrelelöje a tagitiabb nyergessésnel.

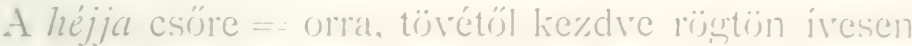

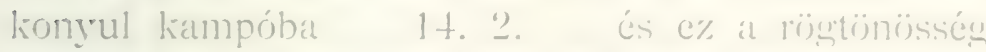

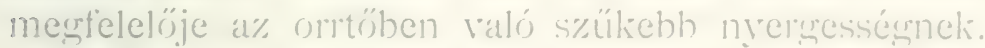

A sémita ory (1:). K. li.) az elöbbiektöl abban kïilön-

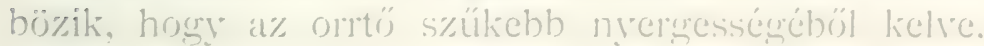


rögtön nagyon boltozatos ivbe megyen át, a melylyel az orr hegye egy vonalba esik; de néha valamivel hátrább is áll, a mikor közszólás szerint: ,papagáj-or"r6́á alakul.

Egészen általánosságban legyen mondva, hogy a szemnek és az orrnak bizonyos alakulata: rézsüntös

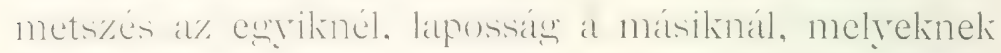

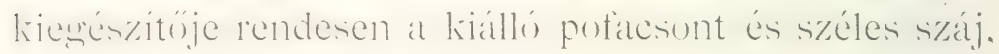
nagy népegységeknek élesen jellemző és oly arczkifejezést kölcsönözhetnek, mely a mimikát lényegesen befolyásolja.

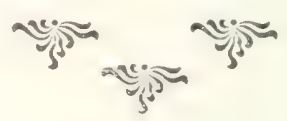




\section{ARCZOK ES ARCみTLATOK.}

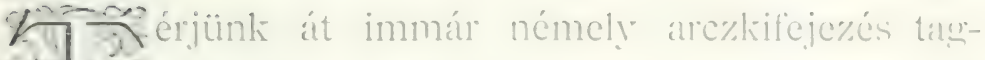
lalására és alakulásának elemzésére, méu pedig azokhoz a kitünó rajzolihoz alkialmazkodva a melyeket Piderit soliszor emlitett muivében küzrebocsatott s a melyeket, mint tudjuk, Hugnes is fölhasznált, mert nem is nélkïlözhette.

Piderit egyazon arczon mutatja mes at arczjátéli változásait, vérén az arczot majd szembe en face. majd oldalt - profil - ahhoz képest. a mint igr. vagy úgy emelheti ki jobban rajzban al jellemzó vonást, ragy a ronások üsszejátszását.

\section{A NETETES ES FOKOZATAI.}

A nevetés skálája, a könnyed mosolytól a féktelen röhögésig igy alakúl:

\section{A MOSOLY.}

A nevetés legenyhébb formája al kïmny"ü mosoly. mely bizonyos esetekben az orcza söjdrïcskéjében is jelentkezik - 15. kép. A güidrï̀stie keletkezése nem a\%, a mit Hegres állit, hogy t. i. a\% arc\%bion a járomesonthoz van hozzínóse. mert ebhen az esetben a gö̈drö̈skie igen magasán állana és nem lehetne a mosoly járulékáa. 
A gödröcske úgy keletkezik, hogy a nevetö-, MinaLkovics szerint mosolygó-izomnak - 8. kép J. néhány rostja nem ér a šájzugtájig̀, hanem már elöbb odatapad a\% arc\% böréhe\% si elikor naygron termés\%etes, houry a midön a mosoly ingerére a szajj könnyedén széthúzódik, valsyis a neretö-izom megfeszül, megreszülnek a\% orcza böréhez tapadt izomrostok is és megallotják a sürdröskiét, mely kivált ifjú nöknél. gryermekeknél nagy bájt és kedvességet kölcsönözhet az arcznak. Eiórehaladott korban a gü̈dröcske mély, güidörszerú

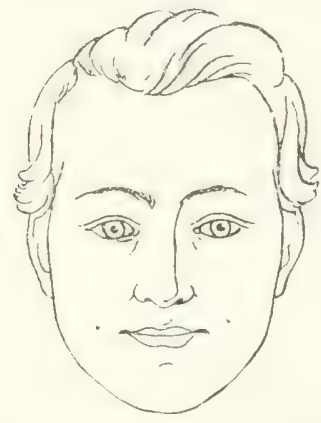

15. A mosoly, az orczán gödröcskével.

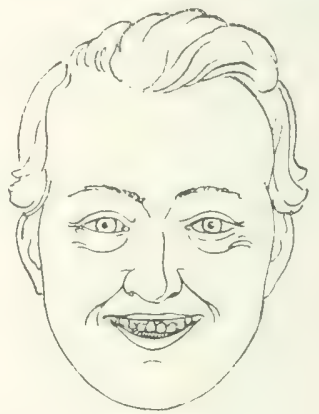

16. A nevetés:

ránczczá alakulva, részben állandóvá s így az arczulatot jellemzö, nem mindig vig jegyévé válik.

Hozzá kell adnunk, hogy a gödröcskék, kétoldalt állva, a száj tengelyébe, vagyis a hasítás vonalába esnek; hogy a száj csukott, vonala hullámos és ez egyberág a szem szelíd, vidám tekintetével, a melynél a szemrés alig észrevehetöen összeszüküll.

\section{A NEVETÉS.}

A mosolyon túl kezdődik a nevetés mérsékeltebb foka - 16. kép, - melynek jellemzése ím ez: a göödröcske jellemzö hatása eltünik - - a hol t. i. van,

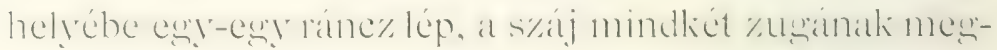
felelöen s mint vonás, az orrczimpáig is terjedve. A szem 


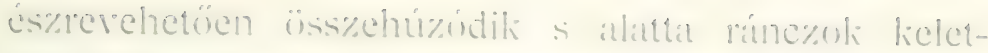

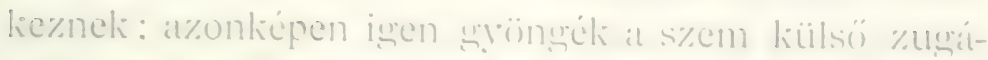
nak mestelelö ranczok is. A nevetés e fokinnal at s\%ilj

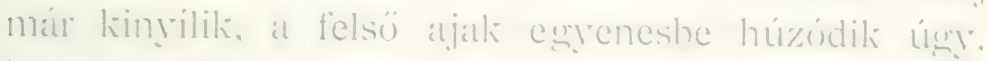

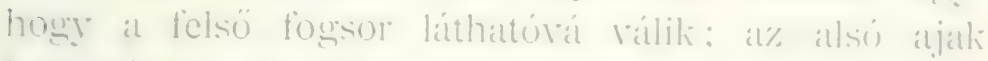
homurú ronalban leronul. A nevetés e fokinnil al s\%enliüzün és homlokon még rine\% nem keletle\%ik: de a lélehzetre való hatáts mál kifejlödik s ho\%\%á simul a mérsélelt hangàdás is. Az are\%ulati állandé

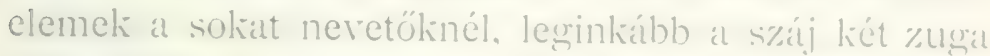
táján töllépö ránczozatban s a s\%enn kïilsö \%uvaitól eredö finomabb ...szartialáb” ránc\%okban rannak kifejezice.

A tulajdonképeni neretésnél leşföképen a\% I. J. I. izmok müködnek - \&. kép - még pedicy a søáj széthúzódásánál, torábbá az F. G. izmok a felsö ajak fölennelésénél.

\section{A KACZAGÁS.}

A neretést köretó fokozat a karagais. 17.k. ¿ melynél mindaz, a mi a nevetés mimikáját mes-

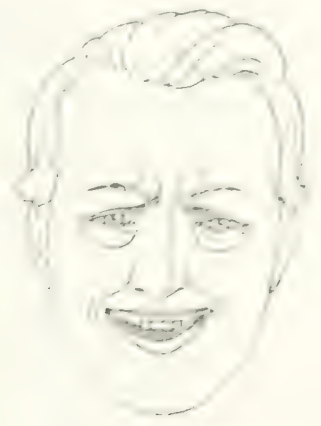

17. A Raczatuin.

alkotja. fokozottabb mértéliben áll clös s horyajjárul még a s\%emkijzi izom beléjáts\%ása is, a mely meröleges redözetet varg lanczozatrot allost: de at or 
gerinczvonala a kaczagás fokozatánál még nincsen megbolygatva.

A szemrés még inkább összeszúküil, a száj tágabbra

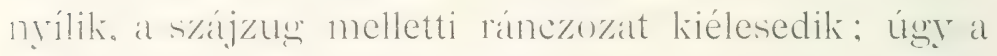
szemkörrüli és a ,szarkaláb" ránczozat is. A lélekzetre való visizathatás fokozottahh és erös szakgatottságának megfelel a kaczagás hangadása is, melyet a magyar elnevezés rithmusa: ,kaczagás“6 kitünően fest.

A kaczagásnál tehát az elöző I, J, F, G izmok jutéliahoz mén a szenkiozi ... I. corrugator supercilii" is csatlakozik.

Nagyon természetes, hogy a kaczagó embernél

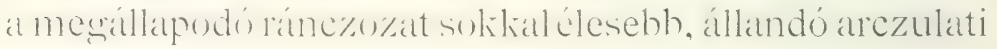
jegyeket alkothat meg.

\section{A RÖHÖGÉS.}

A nevetés fokozatossága a röhögésben tetöz - 18 . kép — és mint tetözö, nagyon érthetö, az izmok játéka is annyira fokozódik, hogy az arcz fel van dúlva.

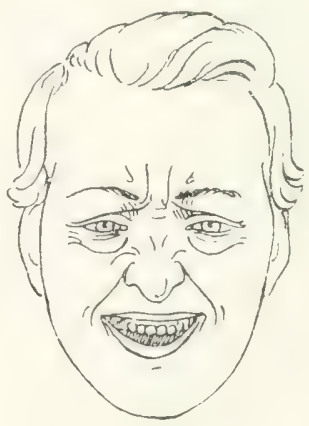

18. A röhögés.

De ha az arczjáték alakulását szorosan szemléljük, egészben azt látjuk, hogy a nevetéstöl a röhögésig szerves kapesolat áll fenn s a három mozzanat alapjahan víve ugyana\%on izmok megterzülésének fokozódó egymásutánját állítja szemünk elé. 


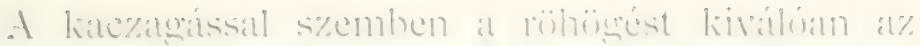

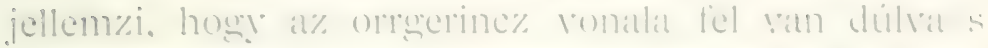
at s\%emliö\% ranc\%ozatithan vallami siljitos jellew toikrözödik viss\%al, mely minthal fäjdalombél eredne. és a\% lige is valn.

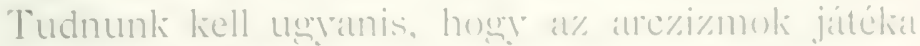
a nevetésnél és a sirisnál, a mennyiben a lélek\%úshe\% viszon ban all, kevésbbe minikus, mint inkihh reflex-mozgís. A\% alczizmok a\% alczides nervers facialis - uralma alatt állanali és minthoug e\% at nỵúltagyból, tehát az érzö ideg̣ek központjánali kijzvetetlen szomszédságából ered, éppen a\%ért erós és talltós ingereknél nemesak a lélelizési idegrekre, hanem az arczidegre is reflexinger hat.

Az egromásután és a fokozatosság igy alakilal:

a) A mosolynál a lélekzetre és más folramatolira nincsen kivehető hatás.

b) A neretésnél rithmikus elem jelentkezik, melyet hang és lélekzet szerves kapesolatban is jeleznek.

c) A kaczagásnál a tartós hatás fájdalomér\%etet szüil és ekikor jelentlieznek a szemkï̃ meröleges ramian.

d) A röhögésnél, ha tartós és hatalmas, a s\%emzáró izmok erös nyomást grakorolnak a kionymirivyekre és ezeliet forma szerint kipréselik; at are\%izmok görcsösen feszülnek; a tartós és erös kilélekzús folytán fulladozás áll be s e\% kinos ér\%ést szüil. mely a keserú vonást is kis\%ólitja. A hatalnuals, talrtós röhöguéssel járó jelenségelet jól jellemzi a matgran-

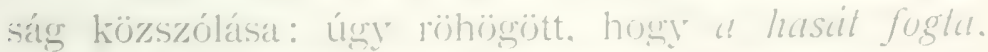
es úgy haczagtam, hogy azt hittem , mespukkadok".

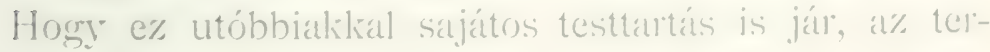
més\%etes.

Némiles kivételt alkot a haholu, melynél lesföi- 
képen a szemköz ránczozata marad el, a száj egész ühlisscégében kinyilik, isy a kilélekzés szabadon törtínik. a fej hatraszegzödili, a mozzanatok összessége a magyar "hahota" szóban kitünóen festett hangadást lényegesen elömozdítja.

Magától érthetö, hogy a nevetés formái evvel nincsenek kimerítve; még azok sem, a melyek természetté válva, nyomokat vésnek az arczulatba. A gúnyos mosoly, a keserú mosoly bizonyos egyéneknél nencsak mint futólagos hangulatok jelenhetnek mes, hogy azonnal eltünjenek, hanem jellemzö alapvonássá válhatnak, mely az illetó arczba állandóan bevésődik. A fél mosoly, a kényszerú mosoly, a fájdalmas mosoly, a leplezó mosoly, mely sokszor a haragot, a szégyent leplezi stb. mindezeli nem jöhetnek tekintetbe.

\section{A SÍRÁs.}

Piderit szerint az ember lelki világában az ellentétek uralkodnak. Túlságosan nagy öröm bánatos hangulatot teremt; igen nagy bánat kiszólíthatja a fájdalmas mosolyt, sokszor a nevetést is.

\section{SÍRÁS ÉS KACZAGÁS.}

Mikor az embert szerencsétlenség, végreszedelem a kétségbeesésig viszi, mint ellentét, hirtelen a kacza-

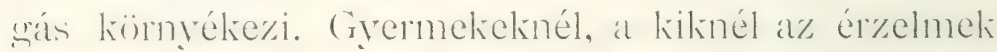

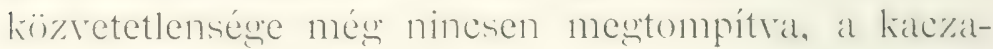
gás átcsaphat sirásba, a sírás liaczagásba. Vannak érzékeny lelkek, melyeket a viszontlátás öröme karjainkba dönt, hol csupa nagy örömtöl hangos zoko-

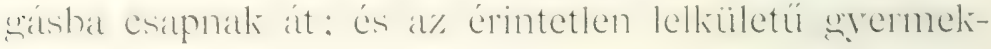
nek könnyeken át mosolygó arczát ki ne ismerné? 


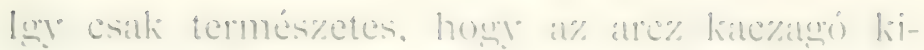

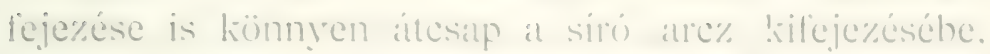
mely utóbbi megulakul, mihelyt a\% orterimpakit i\%matik

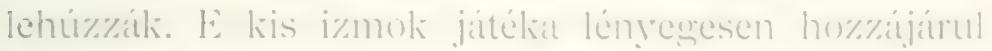

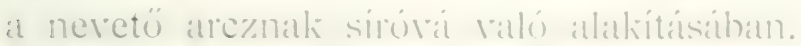

\section{A KÖNNY.}

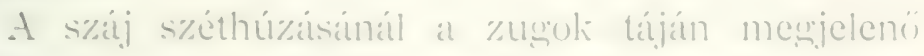

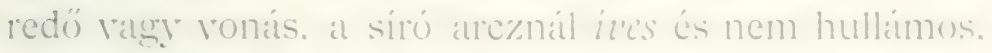
mint a nevetönél. A felsö ajali nem esprenes, mint at nevetö arcznál, hanem a liét (i izom ... S-ik liép megreszülése folvtán liettösen ives. A homlokion at merölegres ránczok határozottan kifejezödnek, mint at

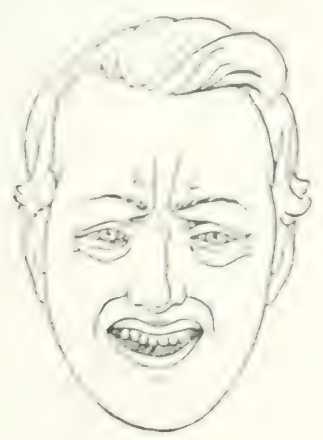

131. A siri arc\%.

fájdalom jelzöi, a szájon a keserú ronás jelentliezil: a könnyek nem müri nyomás alatt, mint a röhr̈gésnél, hanem a belsö ingerer hatalmasságánál fogra jelennek meg.

Fiziolograilag véve azonban al kömmyek nem liizárólagosan arval járnak, a mit sirásnak nerezünk. hanem kiszólíta azoliat a esipös füst, a szembe bejutott porszem. a szarúhártya durább érintése sth. A könnyek kiválása folyotonos is és arra való, hogy a s\%emgolyót nedresen tartsa, at nedresitést az önliénytelen 


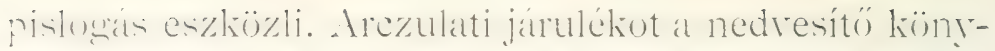

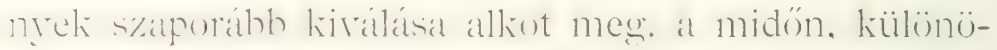
-en ratjongu lelkïiletü emhereknél, allandóan élénkebh fényt kölcsönöznek a szemnek, mely így bizonyos irinyhan fokozotahhmértékhen rálhat a .. lélek tükréré."

De azt is tudjuk, hogy igen hatalmas, különösen lelki fájdalomtól eredó ingereknél - kedveseink elvesztése stb. - a könnyek kiválása a sürú hullásig hatalmas lehet és hogyha ez az inger tartós, a könny .kiapadhat"; a szem ilyenkor elveszti fényét s e fény-

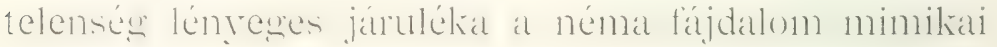
kifejezésének. Annak a tüneménynek, hogy t. i. a kisírás könnyit, enyhít, lélektani és fiziologiai masyarázata bonyolult, nehéz, némely mozzanatában ma még meg sem közelíthetö.

Nagyon érthetó azonban az is, hogy a síró természetü emhernél a siruisial jarrín ráneyetés is állandó. tehát az arczulatot jellemzó nyomot véshet és vés is.

A sirás fokozatainak, mint a pityergés, gajdolás, rívás, bögésnek tárgyalása más lapra tartozik.

A nevetésröl és sírásról szóló fokozatos sorozathan lattuk azt. hour mennyire kiilesïnïsen kiegészitio a szem és száj alakulása bizonyos mimikai viszony-

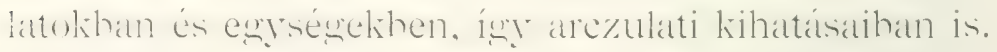

\section{MÁS SOROZAT.}

Most átmegyünk egy más sorozathoz, mely ugyan-

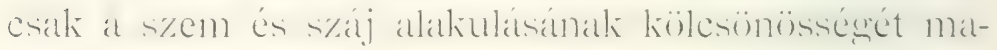
syarázni alkalmas.

\section{AZ ÉDESKÉSSÉG.}

$\mathrm{Az}$ édeskésség, mint ellentétje a keserüségnek, emettól így válik el: a keserú íznek a nyelven való 


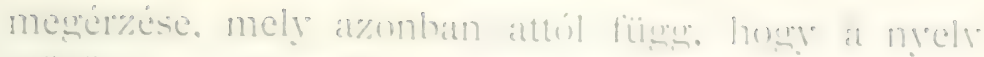

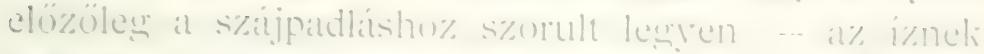

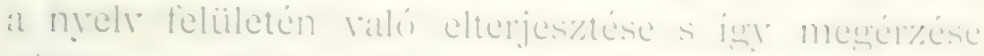

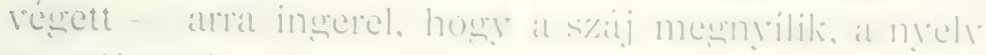

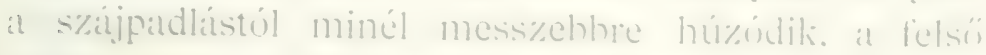
ajak is mess\%e felhumodik a\% alsutol. a felsö aljati emelöje is az orrerimpicie \&. kip. (i lifin.

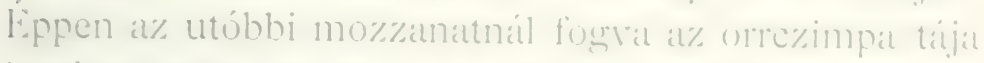
is ribuzot kiap és elöáll a keserü èressnek is mimiliti képe. tz édeskésség ennek éppen ellentétje. murt a\%

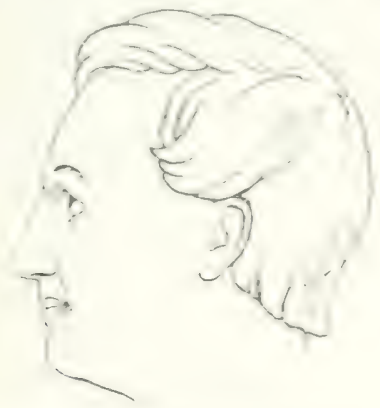

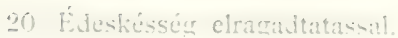

izmok munkája nem arra van iranyitva. hory a rés\%ek eltárolodjanak egrmástól \& ezzel a kellemetlen hatást kerüljék, hanem ellenkezóless. az izmok müliödésc à édességnél az, hoğ a hellenes benyomást. az édesséry hatását tühéletesen fölrehessék. A s\%álj hezillul s à orczákikal egrüitt a fogakhoz s\%orul. F hozzasimulatis folytán az ajkak nem dasadnak ki. hanem meuplaposindnak - 20. kép - s az ezeh révén támadó mimiliai alakzat nemesak édes. kellemes iznél. hanem kivaliran kellemes lelki hansulatoknail is merpalakul. A s\%em s\%erepe nagryon jellemzö. Az édestés väry édes vonásinal. inhább kifejezésnél. a szemnerolyoj fojltelé fordul, jur at szemesillagr a felsö pilla ányériba keriil. kijriilbeliil 
mint a fátyolozott tekintetnél - 10. kép. - A fokozottahb kifejezés elöáll, ha a s\%enn, a szájédes kifejezése mellett, tágra nýlik és a szemgolyó fölfelé fordulva, a szemesillag ányékhat kerül és a szem fejérje alatta kilátszik édes emlékeken vaggr képzeteken való elmerengésnek mimikai képe.

\section{A MEGVETÉS ÉS FITYMÁLÁS.}

Igen határozott és ellentétes hatású p. o. a megvetés mimikai kifejezése — 21. kép. - Itt is a szemé és a

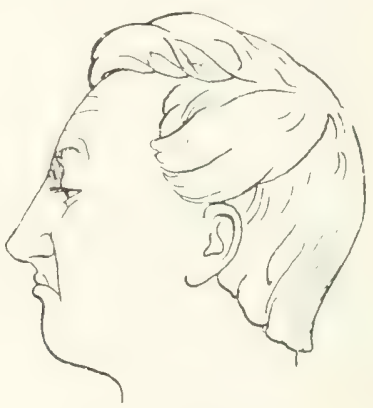

21. A megvetés.

sáljé a föszerep. A testtörzs symbolikájához tartozik, hogy a megretés kifejezéséneli egrik mozzanata az, hogy a fej fölemelkedik, mintegr felibe kerekedik annak, a kit megrretésiel sujtani akall: nem szegezi szemét egyenesen a megretés tárgyára, hanem kicsinylóleg oldalt pillant rái: a szempillák lecsukódnak a nélliül, hogy záródnának s a szem bizonyos kedvetlen figyelmet árul el, melyet a homlokon keletkezó harántos ránczok és a s\%emöbök felronásiat alakit meg. Fokozott mescretésnél kiozhejatszik a szaj alakulasa is: a két szajzug lekonyul. a szilj körepe feltolódik, igy a s\%áj ivet alkot, mely a\%

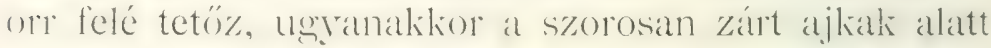

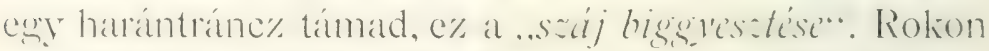
evrel a fitymálás mimikai képe is, a mikor a meg- 
retést kifejezö szájallakulat hirtelen mo\%uishan timnat is envesisili.

A megretésnek rendesen és erösen kifeje\%̈̈dö mimi-

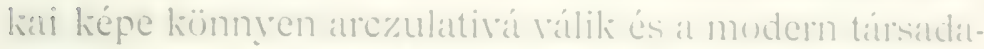
lomban igen gratiori. Megrögritve, at homlok ráne\%ail.

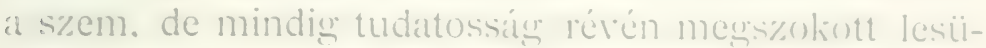
tött voltal és a szál iresséue fejezi ki.

\section{A FESZÜLT FIGYELEM.}

Az elözörel szemben a fissült fisuelem licje 22. kép - mintegy fölengedést tüntet föl: de ismét at szemi és a saijé az alakitás föszerepe. Feszült hallevittódzásnál az alsó állkapoes mintegy lecsik, al s\%ál meu-

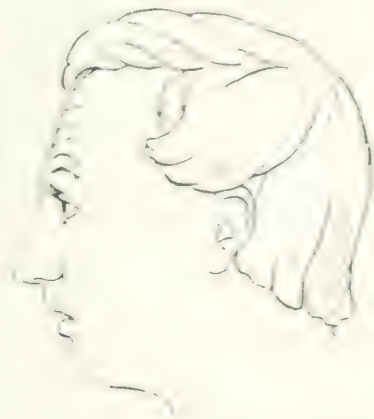

22. A reszuilt figyelem.

nyilik, hogy ez is fogja föl a hanghullámok eçy részét. magyaar szólás szerint: . hisy bámult, hosy leesett a a cilla." A feszült figyelem lesmagasabb fokozatánál az elcsodálkozással való rokonság is áll eló és a s\%áj mimiliat alatkulatához hozzájárul a tágra nyitott szem, a felvont szemöldök és a homlok harántránezozatat. A kijzs\%olás "t figyelem legnagasabb fokat isg jellemzi: .. Mimeres: tette szemét. leesett az cilla: a csodilkosistril eltcitolta "l sacijüt: Korlátolt elméjü. nehéz felfousású, mindenen elbámés\%hodó embernél a leirt mimikai kép kïnnyen és élesen rögzödik merg arczulativé. 
Az eddig letárgyalt mimikai képletekbool eléggé kirehettük a szem és a száj jelentőségét, döntő szerepét at allejatíkhan : de kivehettük arezulati, fiziognomiai jelentróséuét is. Ezeket jól kell emlékezetünkbe résnünk.

Most átmegyünk egy rövid sorozatra, a melynél a száj ki van igtatva és csak a szem uralkodik a mimikai képleten.

\section{A MEGLEPETÉS.}

Nát elözöleg megrismerkedtünk a feszült figyelemmel - 22. kép - és avval a körülménynyel is, hogy

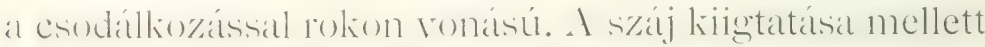

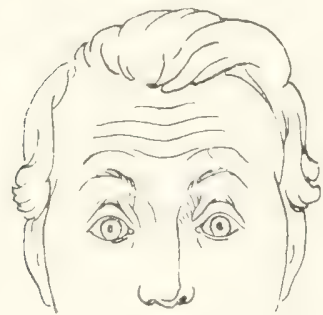

23. A legnagyobb meglepetés.

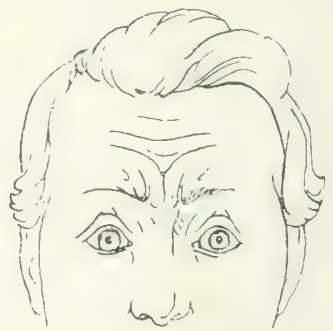

24. Nagy ijedelem.

a 2:3. Kép a meglepetés legmagalsibb fokít adja. Minthogy a meglepetés mimikai képlete a dolog termés\%eténél fogva hirtelen támad, a szem hirtelenül nagyra tágul. eqyben a szemöldö is magasra felrántódik és közbejátszik a homlokizom is, mely a harántránczozatot megalliotja. A meglepetésnek és isodullkorismuk.

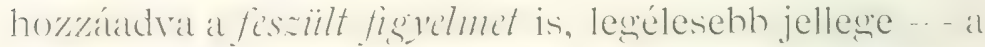
szem kifejezésén kívül - az, hogy a szem közén meröleges ránczok sohasem alakulnak.

\section{NAGY IJEDELEM.}

Noha a szem erószakos meresztése az elöző mimikai képlettel azonos, a nagy ijedelem - 24. kép — mégis cényegesen különbözik. A natgr ijedelem is hirtelenüil 


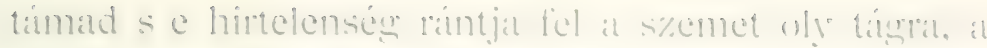

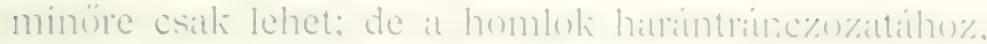
mely at mestepetést jellem\%i, at meglepetess\%erten

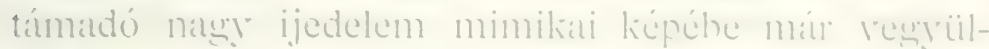
nek a szemkë̈ün a\% erös. merölenes rinc\%oli is é. ezek döntik el a\% ijedelem mimikati képének jellenét.

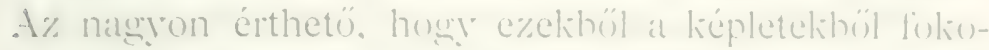
zattossigrat nézve sok viltozalt telnék, e\%elinek letitiyvalásia azonban nem e mü keretéhe tatrtozili.

PIDERIT ${ }^{1}$ a szem nyitiscira vonathozo és idetartozi) mimikili mozzanatokat isy öss\%egezi :

... fádradtan lesütütt szempilláli testi fäladtsíg(ut. vağ szellemi liözönyösséget jelentenek. Fijlemelt s\%empillák, tágra nyitott szem a meglepetés, de a les\%uilt figyelem mimikai kifejezöi is."

..Ha ezelihez még rizszintes homlokránczok, fölrántott szemöldökök járulnak, akkor a szemek mimikati

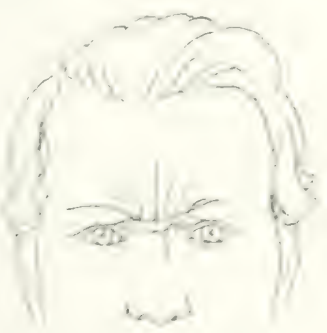

25. Rossticdr, haras.

kifejezése a nagy meglepetés vagy a nagyon feszült figyelem." És ervel ennek a sorozatnak utolsó képéhez jutottunk el.

\section{ROSSZKEDVÜSÉG ÉS HARAG.}

A sorozatnak utolsó képe a "joj-ik, mely a rossäkedviiség haragos fokozatit mutatja be, a mint a\%

1 Pijerit. i. h. p. ij: 
nagyon élesen és jellemzöen tükrözödik az emberi arczban.

A szem a harag ingere alatt rendes nyílású, de szegezö tekintetü, mintha az indulatot okozót át akarná hatni. A homlokon a vízszintes ránczoknak semmi nyoma; annál hatalmasabban jelentkezik a szemköz meróleges ránczozata, még azzal is fokozva, hogy az orr kelló tövén, a gula-izom — 8. kép $\mathrm{N}$ issszehuzodása folytán egy harantredö tamad. Térednénk azonban, ha azt gondolnók, hogy a ránczvetésnek ez a neme kizárólag a rosszkedv, illetóleg harag mimikai képletét alkotja meg. A ránczozat e neme sokszorosin kilejezöje szerencsétlensémnek, boldowtalanságnak, a kedvetlenségnek, mely még nem az, a mit rosszkedv alatt értünk; de képe a beható gondolkozatsnak is, küilinösen annak, a mely megreröltetö a nélkül, hogy a gondolkodót kielégítené.

\section{ÖSSZEGEZÉS.}

Mielótt az alkalmazásra térnénk, jó lesz az eddig elemezve mondottakból néhány tételt levonni.

1. Az emberi arcz rendesen muló jegyei belsö ingerek tartós vagy állandó behatása alatt arczulati

fiziognomiai - jegyekké válhatnak és ekkor az arcznak egrénileg sajatos. ú. n. tipikus kifejèśst adhatnak.

2. Ugyanilyen jegyek külsö ingerek behatása alatt

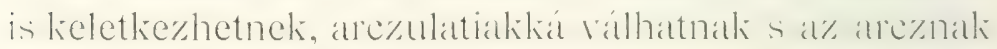
sajátos kifejezést kölcsönözhetnek.

3. A belső és külsö ingerböl támadó vagy eredö

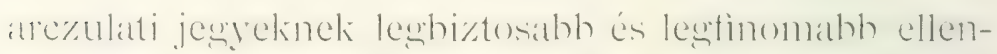
örzöje a szem kifejezése és vele a száj kiegészítö, azaz kölcsönös alakulása. 


\section{(i)AKORLAT ALKALATHS.}

\section{AZ IRÁNY.}

Az eddign mondottak alkalmazisitial két út aill elöttünk: rạ̣y köretjük a mimikusok és tiziognomok eddigi eljárátsait, illetöleg útjat, mely abban áll. hogy megrhatarozásaikat, sémálion kíväil, nagryirü. hatirozott jellemú emberek arezmásáthoz és jellem-

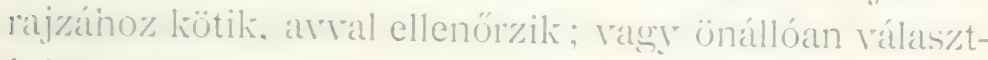
juk meg a\% utat úgy, a mint azt az irány, a\% anyag és a végsoö czél megrizabja.

\section{ARCZKÉPEK ÉS SZOBROK.}

A régsó czélra nézre, mely a magyar arow és vele a magyall jellem meghatározását jelenti, levés. soks\%orosan semmi haszna sinesen p. o. a PIDERIT igen kitünö mürének fiziognomiai részéhez tártozó arczképekböl, részben antik szobrokról és újabbkori festményekröl vett jellemzö sorozatoknak, a melyek természetszerüien csak arra szolgálhatnának, hogy a masunk nağ: ismeretes fértiainkat összemérjük velük

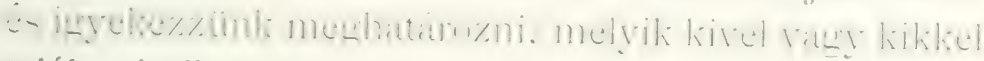
talál mimikai, fiziognomikai tekintetben és mennyire fedik ezek azt a képet, a melyet jellemüikröl birunk:

Magrall hadrezéreinkben megran-e a Napoleon, Kléber, Nagy Frigyes stb. fiziognomiai képe? Emberbarátaink mennyiben mutatják a Franklin Benjamin jellemzó vonását, miben és mennyiben? Tálálunk-e

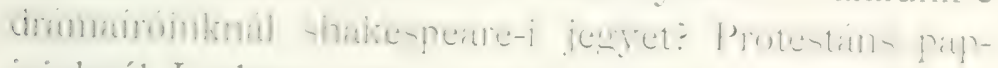
jainknál Luther- vagỳ Kálvin-vonást és mennyit?

Vem tekintre, hogy az ilyen összehasonlításoknál már a faji kérdés _... a mennyiben egyáltalában felrethetö - mindenképen nagy akadályul szolgál, vannak még más igren lényegres okok arra nézve is. 
hogy ezen az úton egy adott nép vagy nemzet sajátos, jellemzó vonásait nem állapithatjuk meg.

Azok a kiváló módon kifejlett mimikai és arczulati aysersek, a melyek az igazi nawy jellemekben tükrözödnek, éppen úgy, mint a jellemek magok, az emberisçne titroznak, crak önmagukat példázzák és bizonyitják; kivételesek és éppen azért nem általánosíthatók s nem lehetnek összefoglalók sem.

A magyar arcz meghatározása tekintetében még exy más. igen léngeges nehésígbe üthözünk, at melynek legyözése, mihelyt az általánosságot vesszük, lehetetlenség elé állít.

\section{BAIUSZ ÉS SZAKÁLL.}

A mimikusok és fiziognomusok összes tipusai, a mennyiben sematikusok: bajusztalanok és legtöbbször szakálltalanok is; ez nagyon természetes, mert a szem és a száj egymást kiegészító alakulása máskép ki sem rehetó, tehát nem is méltatható; azonképen rajta vannak, hogy bizonyító tipusaiknál is szabad legyen kivált a száj, — lévén a szem természettól fogva az.

Így PIDERIT bizonyító tipusainál csupán JoHANNEs Mülzer visel ú. n. Kossuth-szakállt, mely a mult század hiozepe taján oly divatos volt a magratr úrirendnél. de a java népies elemeknél is, az utóbbiaknál a korosibhak még ma is hivei: Ugrancsak Motuer bajuszos is, a bajusz azonban alig árnyékolja be a felsö ajkat,

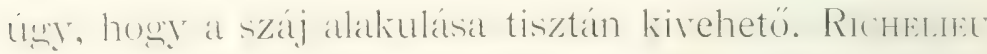
spanyol — kecske - szakáll mellett fölfésülve viselte bajuszát, úgy, hogy a száj szabadon maradt, alakiulása kivehető volt; még az emberbarát SPEner-nél

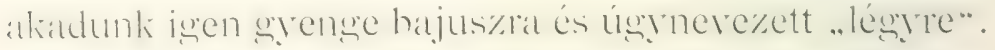
.I töhhi fiziognomial tipus hajus\%talan, s\%ahilltallan. 
Meröben kopasz arezú a liegretlenség örök tipusa. Nero: a fátjalomé és félelemé, Laokoos. Ezek mellett a\% .. olympusi" Golthe, a filozofus Locke, a zenés\% IVeber, a szellemes Jean Palu, Fro. Richiter, Cromweld, ('Hodowazzk stb., stb.. mint látjuk, mind önálló, nem illtalánositható és nem gyúijtö, összpontosító alak.

A nehézség ott kezdödili, a hol a mimikai és arczulati képletet lényegesen alkotó rész fedre van, mint fedi a szájat a lényegesen árnyékoló bajusz és a szakáll is, ha az orczán a száj közeléig tolul.

Vizsgáljuk meg ezt a viszonyt és jelentöségét. SCOTT ÉS IRÁNYI.

Scott INinfered amerikai tábornok - 1786-1860 mint az eltökéltség, hajthatatlanság, mondhatni nemes konokság mintaképe ismeretes és ez a tulaj-

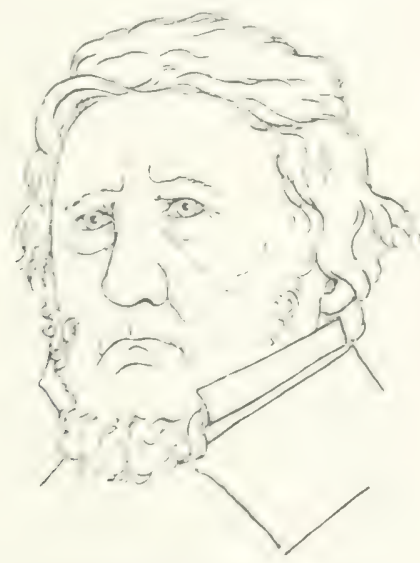

2ri. Scott amerikai tábornok.

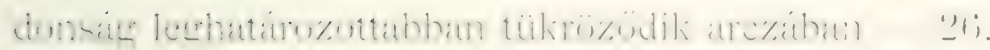
kép - is. Az átható tekintetü, mondhatni szegező szem, a szemköz meröleges ránczozata, de különösen

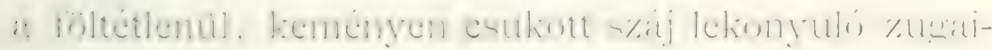
val, a száj alatt az éles harántránczczal, oly fiziogno- 
niai képletet alkotnak meg, mely világosan mondja, hogy ez komoly, eltökélt, hajthatatlan férfi, a ki nem

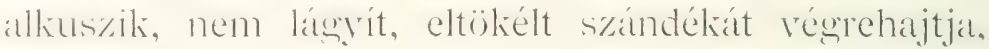
ha belepusztul is, az igazi: Et si fractus illabatur orbis, impavidum ferient ruinae".

Ez a mimikai-fiziognomiai képlet nagy részben volt meg Irányi Dániel magyar képviselő arczában, avval az egy különbséggel azonban, hogy szeme nem volt oly szegezö és inkább fokozott önérzetet, hozzá bizonyos fokú rajongást tükröztetett vissza; különösen mikor szónoklata tetözött s ö maga hirdette saját

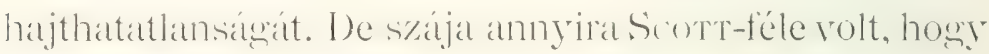
azt az árnyékoló bajusz és a szakáll sem tudta elfedni, mindliettö ar vnás, a szajunctszés menetéhez illeszkedett.

Evvel természetesen az amerikai ember nincsen fajmagyarral szembeállítva, mert tudvalevö, hogy IrÁnYi a Szepességnek nemcsak szülöttje, hanem ösi soron származottja is volt.

\section{BEETHOVEN.}

A hajzat és szörözet jelentőségét még ennél is élesebben magyarázza és bizonyítja p. o. BeEthorex arczképe és az azzal végzett kisérlet.

A mi a Beethoven arczából sugárzik, az a szemben bizonyos rajongás, a szemközön a gondolatokba való elmélyedés, bizonyos keserüség; de Piderit jól jegrezi mes, hogr a staj e\%ekhe\% képest túlságosan lágy, majdnem mosolygós kifejezésü és lehet, hogy a rajzoló, noha camera lucidával dolgozott, nem adta visszal teljesen a száljak kenényehb kifejezését, a mint azt a szem és szemköz alakulata követelné. Hozzá tudnunk kell, hogy Beethoven siketült is, tehát fizikailag és ezen át psychiliailag oly állapotba jutott. mely nagyon is mély és határozott barázdáliat von 
kiilïnüsen a müvelt, Émékeny lelliületü emher arczibat. a szemet pedig különösen s\%egeröré tes\%i. ment a sï̈-

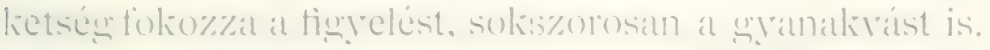

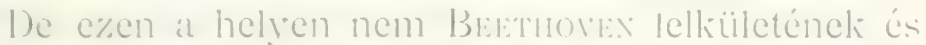
miniko-fizionnoniati köretlezéseinek elenzéséroul ran

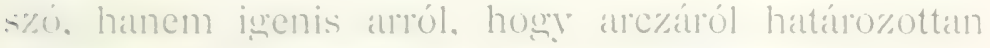

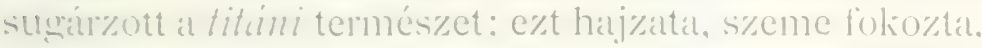
és alliotni segitette és semmi kétsége, hog̣y ha Sornack ismeri a\% oroszlán arezulatát és redözetének alliotó szerepét, hozzá a sörényét, és ismeri BEETHovex-t. mondjuk. semmi kétsés. hogr ez utóbbit teszi a\% oroszlánnal páros huzanba, nem pedig Kúber-t, kinek arezal nyilt, ki BeEthorex borongé arczulatátáal viszonyitra. maljdnem a gondatlan bonvivant benyomását teszi - lásid elöl 3-dik kép.

\section{A HAIZAT JELENTÖSÉGE BEETHOVENNÉL.}

Howrha most a 27. és 2S. s\%ámú ikerképet tekintjüik. melyet a múvész a döntö ronásolira nézve nem

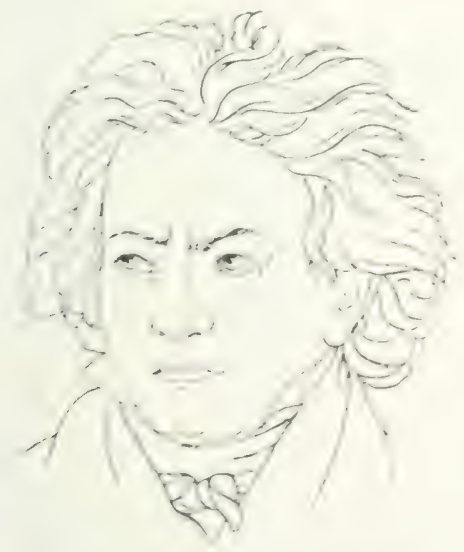

2-. Beethoven sajät hajzatival.

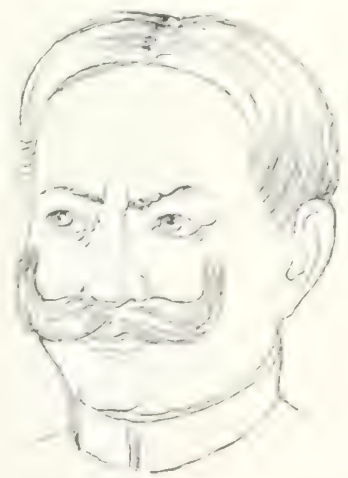

28. Becthoven ery porosz tiszt hajzatávil.

is a camera lucidával, hanem átláts\%ó papiron át másolt ki PuERIT múréból - ..67. liép - - és s\%erelt 
fel hajzattal. illetolecr szörïzettel, tisztán és rilágosan látjuk az utóbbi kettönek roppant nagy alakító és ditalakito hatálsat. nay jelenteóségét tipusok rizsgálatá nat és meshatározísánál. I)e látjuk a szemnek, mint “ kélek tükrének. diontö jelentöségèt is. mert határozottan kialakulva, változatlan marad.

És ekkor feldereng elöttünk a felelet arra a kérdésre is: miért oly idegenek hozzánk a LAVATER tipusai, noha rannak kïzöttük mürészektöl eredök is?

Nem tekintve, hogy a müveltség foka, az uralkodó világnézlet is korról korra tükrözödik a társadalom arczulatán, a haj és szörözet kor szerint való viselete kiváló módon alakítja át az általános képet.

A midôn a mult XIX-dik század elsö felében a

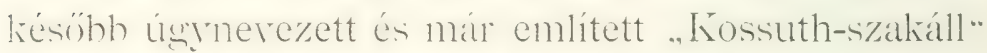
ciltalánosan divott, mely az arcz egéses kerüilélét szathadon haserta: de azért a hajusz ámvélioló formában megmallat, íy nem volt kivehetö a swem kifejezését

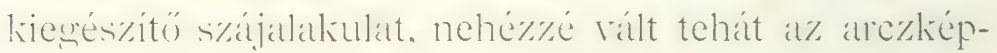
festésnél az egyéni jellemzés. És innen van például Barabás Miklós egykorú kórajzain a férfi arczképek-

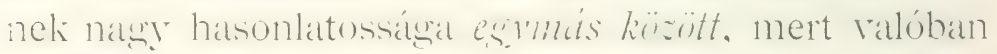
mes volt nehezitre a jellemzó haj és szörözet viselete

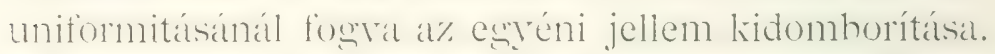

Ám ez a viszonylat még élesbithető is, még pedig ¿ küvetliezö kisérlettel.

\section{DEÁK ÉS DERBY.}

Dé́K Ferencz — 1803-1876 - és Lord Derby

1799 - 1869 - némely tekintetben egyező jellemü

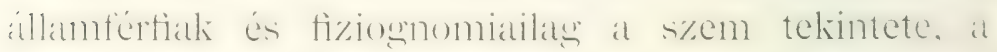

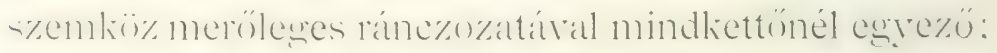
igy az orrezimpától a szájzug felé futó ráncz vagy

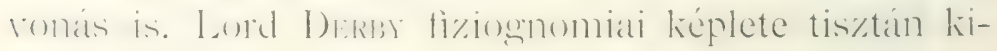




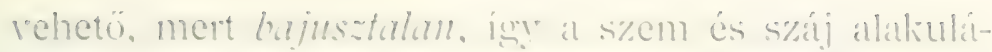

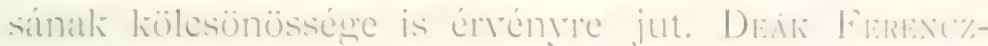

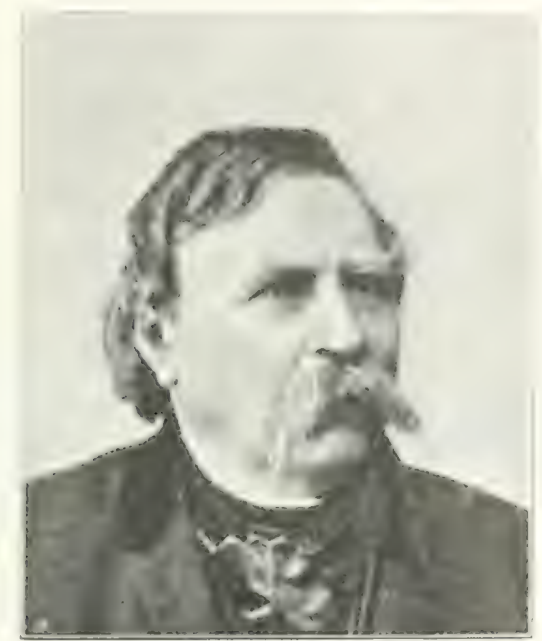

29. Deak Ferenc\%. 18(1):-1876.

nek hatalmas, száját nagyon ámyékoló bajusza van. igr fiziognomiailag tisztán a szemre, az orrkörüli

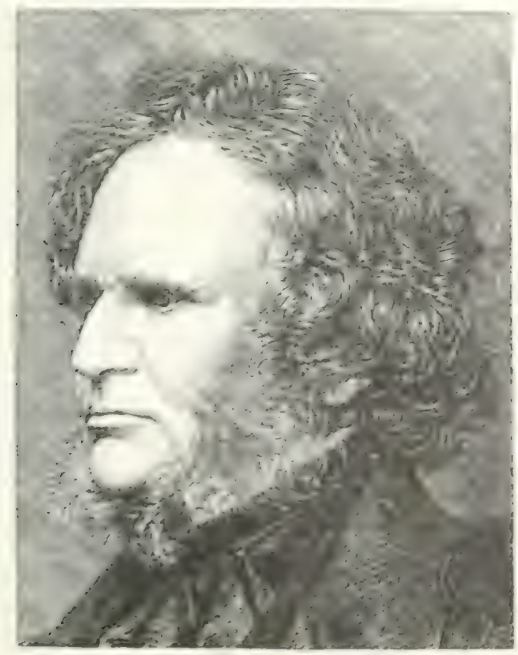

:30. Lord Jerby 1799-18499. 
ránczvetésre és az áll tulajdonságaira vagyunk utalva, mely utóbbi mindkét államférfinál egészben véve egyezó.

DeÁk-nál és Derby-nél a szem szegezó, akaraterót kifejezó; Déx Ferexcz-é áthatóbbnak látszik, a mi azonban a bozontos, hosszú szemöldöktól is füigg.

Deák orra egyenes, Derby-é sasorr.

DEÁK szakálltalan, Deriy pofaszakállt visel.

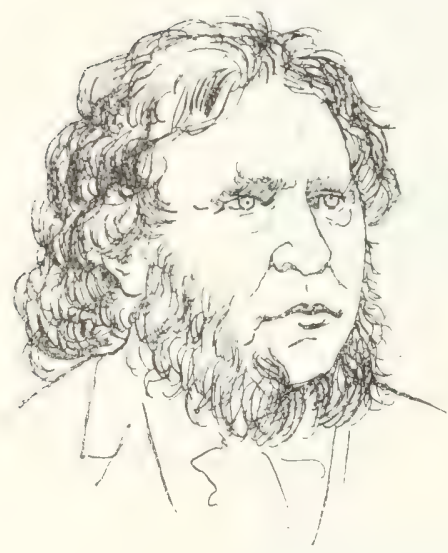

31. Deák Ferencz Lord Derby hajzatával.

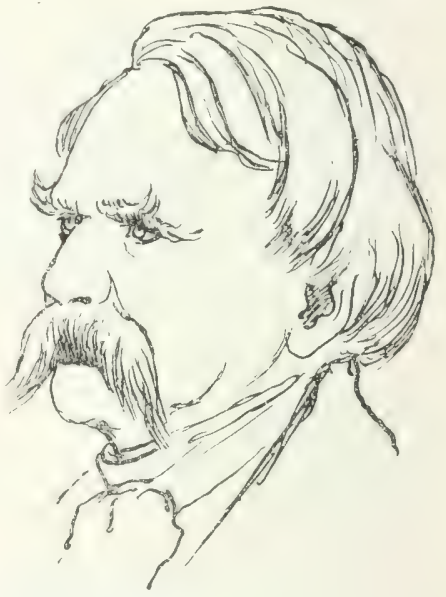

32. Lord Derby Deak Ferencz hajzatával.

A kérdés immár az: mi lesz az eredmény, ha e két markáns és egészben egyezö férfiarcz hajzatát és szörözetét kölcsönösen átruházzuk?

Az eredményt a 31. és 32-ik kép mutatja.

A két államférfi arczulata az alkotó vonások szerint átlátszó papirra át volt rajzolva és a hajzattal való fölszerelés a lehetóségig a képek szerint történt.

Az eredmény meglepó, a mennyiben világosan mutatja azt a roppant alakító erót, a mely a magyar bajuszban, szemöldökben rejlik, mely Lord DERBY 


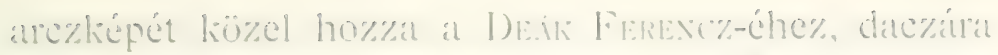

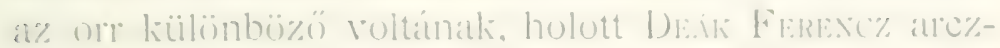
hépe Deris: hajzatitiat nem hasonlit DERb-he\%, mert Deik stajalkotásit nem ismerjül, orrat exyenes st at budros hajban és a pofäszahállban ninesen megr a\% a\% atlakitó jellemzö erö. at mely az erös fejlödésüi. s\%átjhoritú batus\% tulajdona. A bozontos s\%emijldijli elmaradása sem öreşbiti a DERB-rel való hatsonlóságot.

Bizonyosnak rehetö, hogy ha SeHAck úgy ismerte rolna az oroszlánt. a hograan kell, minden bizonnyad Lord DERrs-t is választotta rolna a\% oroszlán párosának. a mint ezt à Specht-féle, arczélben adott orošlán

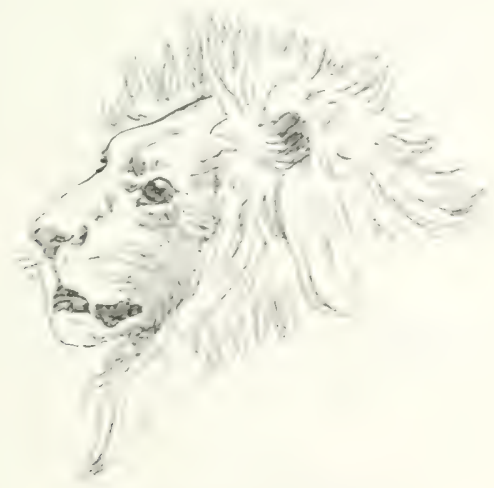

3:3. Croszlán a seribáhan.

- - 3:3. Lép - Lord DEREY képérel összehasonlítrà. világossá teszi. 'Tisztá és világos azonban az is, hogy" ilyen összehasonlítások és az azokiból vont köjretke\%tetésch a játékiok sorába tartoznak.

\section{A GONOSZTEVÖK HAJZATA.}

Jagyon érdeles riszont az, hogy a hajzat és szörözet átalakitó hatását grakorlatilag a gonoszteróli allialmazták és alkalmazzák sikerrel: nem a vendéçhaj és rendégszaliáll formában, mert e\% csak szorult- 
silghan. magrarán mondra „futóban“, kisegító eszköz: hanem a természetes szakíll és bajusz átalakításátral és esrehelikel, p.o. fogsorral és a nélkül. Legújabban

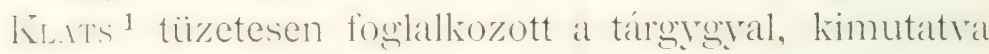
fényliepek útján. hogr a gronoszterök ralóban csekély eszközzel majdnem teljesen felismerhetetlen arczot ölthetnek és elvegyülhetnek a társadalomban.

A midőn a magyar arcz meghatározásának nehẻz feladatához teljesen táreyri alapon és tárgyilagos formátban átmennénk, az elözökböl már most is tudnunk kell, hogy a megoldásnal sok esetben nélküilöznüink kell a\% eşrik lényegres alapelemet, t. i. a sarij alakulátíinak tiszta képét, azért, mert a magyarság nemesak hajus\%s, hanem hajuszatra hüs\%le, ebben tisztességének és tekintélyének eyrik nélküilözhetetlen elemét ismeri föl. A magyar arcz meghatározásánál tehát kétszeresen is a szemre esik a fósúly.

1 Klats O. „Die Körpermessung der Verbrecher nach Bertillon und die Photographie". Berlin, 1902.

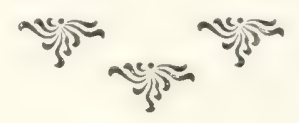




\section{AZ ARCZKEP ES AZ ENBERTAN.}

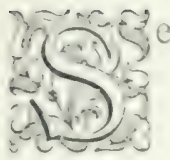

emmi kétség, hogy a pusztán mérésckre, azolinak viszonyitására és némely arczulati viszo-

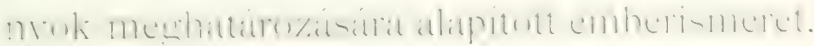
magáról az emberoól és arczáról nem nỵujthat tis\%tal képet: lényéröl éppen semmifélét.

A midön a ., fölvétel " megállapitja képletét és eg̣! adott emberoól himutatja, hogy ,magas termetü + kék komplexiójú + hyperbrachykephal + hypsikephal + chamaeprosop“. ragy kiteszi, hogy ,a fej kerülete $570^{\mathrm{m} / \mathrm{m}}$, a fej jelzöje $(166 \times 100: 199=-) 834^{\circ "}$, úğ ezek mind megfelelhetnek a valóságnak, de nem alliamasak arra, hogy az illetö egyén arczképéról. annak fiziognomiai alkotásáról, az ebból kisugár\%ó lényéröl, báresak halavány fogalmat is nyujthassanak. Hogy ezt megkaphassuk, arra való az arczkép, mely nélliül a legrészletesebb és legpontosabb méréseli és mértéliriszonyitások mellett sem állapithatjuk mesn a17t. a mit csak a leghivebb, minden föltétellel bíró arczkép világosithat föl, úgy a\% egyénre, mint ará ¿ faji, társadalmi vagy más egységre nézve -. a\% oly fontos közös vonist illetöleg - a melyhe\% a\% egrén tartozik.

\section{A FÖLVÉTEL.}

A tételes összeforlalás isy alakill:

1. A feladat. Hogy az arczkép, a fej és arc\% 
somatikus idomainak összealakulásán, tehát a fiziognomián kívüi, a psychikus - lelki — tulajdonsá-

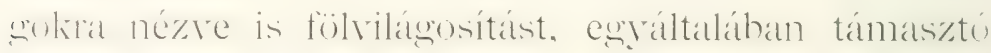
pontokat nyujtson.

2. A fillitil filtitili:

a) $\mathrm{A} z$ arcz rendes legyen; a fölvétel pillanatában ne dúlja fel sem külsö, sem belsó inger.

b) A szem rendes, kifejezése természetesen-normális legyen; mert csak ekkor lehet a "lélek tükre".

c) Az arcznak és arczélnek tükör alkalmazásával esridejünek. egrazon vilásitásunak kell lennie, mert a társitás csak így válik lehetövé.

d) A járulékok, a melyek az arczulat tekintetében alkotó természetüek, mint haj, szakáll, bajusz, viselet szerint ne egyéniek, hanem lehetöleg közkeletüek legyenek.

e) Hogy egyazon eszme hatása alatt végezzük a felvételt. Rólam tudják, hogy az igaz magyarokiat tanulmányozom, így evvel a tudattal ülnek a múvész vagy fotografus elött.

3. A kiválasztás. A mily könnyü fajnépek körében az anthropologia szolgálatában és érdekében a megfelelö egyéneket kiválasztani, oly bonyolult és nehéz ez a feladat oly népekkel szemben, a melyek szörevényes keveredések eredményei.

Súlyosbítja a feladatot a történeti kiindulás bizonytalansilüa, a\% elregräilések menetének és allintonés\%eli

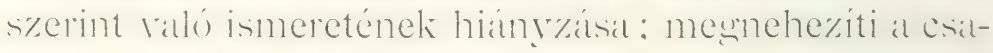
lídrobl valo korszerinti fölfogits hiztos liépének ismeretlensége; súlyosbítja a történelem egyoldalú múvelése. mely csak nagykésöre, napjainkban, ébredezik arra a tudatra, hogy a történet nem genealogiákhoz kötött

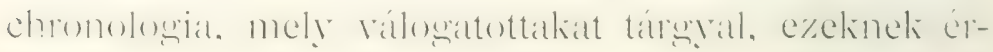


delibben pedig néhal oly erösen szine\%, at mint e\%

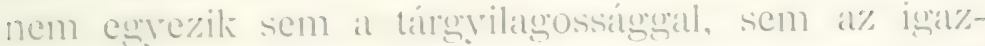

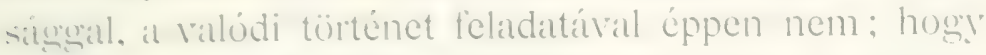
evoel s\%emben a liorténet feladatat a\%, hogr a\% egés\%et minden rés\%ében üss\%etorglaló, kifejtó lesyen és hogy a\% enésznek mesillapitásiból fejtse ki azt, a mi valónak bizonyitható, vasy legalább a legnagyobb való«\%inüiscurgel föltehetö.

\section{A KIVÁLASZTÁS ÉS A MAGYARSÁG.}

Tudnunk kell, hogry mindaz, a mi régmult šáátdok krónikíja, alapnak ingatag; mert minél távolabb esió idöröl szól. annál korlátoltabb elemektöl ered s annail inkább játszik belé a való és az igazság rovására menö érdek, a multak tárolságával mindig növekedó emberi grarlóság; nem tekintre még azt az ösgyarlósigot is, mely a krónikások és egyéb források emberi voltából fakáad s melynek neve a minden áron való

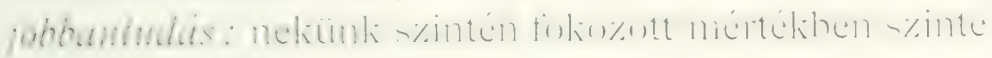
nemzeti tulajdonságunk.

Lehetetlen volna ezen a helyen; de nem is szül-

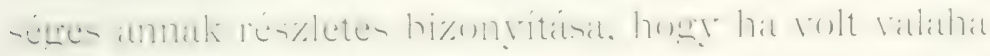
nemzet, vagy nép, melynél az anthropologia szolgálatára szánt arczképi anyag kiválogatása az imént vazolt körülményeknél fogva megr volt nehezitve, a magyar minden bizonnyal az. És éppen mert a\%, nines Magyarország területén rész, a melynek csak úgy vaktában nekimehetnénk, a melybe éppen esak belémarkolhatnánk, hogy a mit kimarkolunk, az biztosan mind csupa s\%emenszedett "magyar tipres" legyen. Jagy baj, hogy igy van; de esakugyan igry van!

Ezen a helyen csak azt a legkevesebbet érintem at mit s\%em elött kell tartanunk, a midön a magyrar- 
side embertani arezkép-anyagának kiválogatásáthoz fognánk.

1. Tudnunk kell, hogy a nemzetnek, az újkorig terjedve, rendi alkotmánya volt.

2. Hogy a birtok rang és hatalom szerint való förend. Vargoni érdekhöl: de az indigenatus hatalmas hefolyásat alatt is. különösen Mohács után, nagyon elvegyült.

3. Hogy a jobbágyság intézménye, nagyon érthetö okoknál fogral mert sokszorosan szolgaságból. sót ösileg rabszolgaságból eredó elem, nem lehet alkalmas; söt legtöbbször elvetendő.

4. Hogy a nevekre igen nagy súly tartozik, nemcrak azokra, a melyek hïzretetlenüi más nemzetiségi származásra mutatnak, hanem azokra is, a melyek más területekre utalnak, vagy tartoznak.

5. Hogy számolnunk kell, nem a rendeket, hanem a nemzetet fentartó összes nagy foglalliozási ágakkal $\therefore$ az azoliat üzö "̈si eleneklel, a melyek az eredetisér böl legtöbbet tarthattak meg.

6. Hogy az összes ethikai alapot és tartalmat kell tekintetbe venni, annak sajátosságait ósi soron a jelenból risszatelé kioretieztetre, kell megrillapitanunk és csak ekkor szabad választanunk.

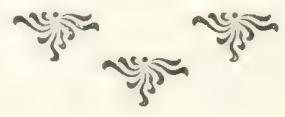




\section{A MEGILEVO ANYAC.}

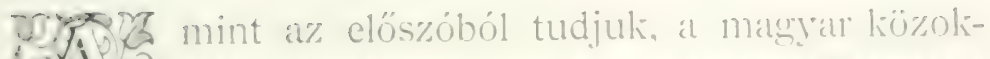

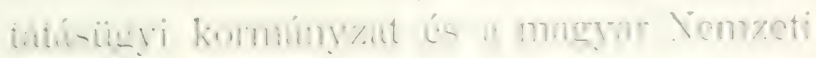
20 Muzeum tekintélyétól támogatra ceg kiadvainy osztatott szét az 1900-diki párisi világkiállítás alkalmáral megtartott XII-dik régészeti és embertani rilágkongresszuson, mely ., magyar tipusok czím alatt t8 anthropologiai arczliépet ${ }^{1}$ foglal magában.

Minden egyén arczképe szemben - en fále és arczélben - en profil —, alatta a legszüikségesebb tudnivaló, mint: nér, származási hely, foglalkozás, kor, haj és bajusz szine, szem, orr, termet; a fej kerülete, a fej jelzöje.

Az arczképek kellö nagyságban vannak fotográfozra: a felvétel módjáról majd alkalmazottan lesz šó.

Minthogy ez a magyarságra nézre mindenesctre úttörö munka, mindenekelött el kell ismerni, hogy a somatikus részt az arczlépivel összeliapcsolva, a módszer, a melyet így követ, elfogadható.

Az arczhép-anyagot tájékoztató bevezetés elözi mes, a melyböl megtudjuk, hogy a terület, a melyröl ezek a "magyar tipusok" rétettek, a Balaton

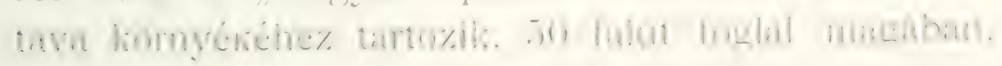

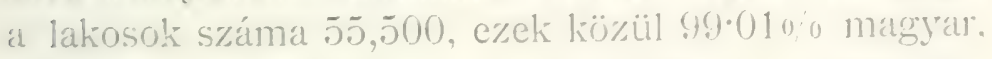
().90 o német, horvát, tót és „egyééh. A megyei fel- 
osztás szerint 8 helység Somogy, 1 helység Zala területéhez tartozik; Veszprém teljesen kimaradt.

Családnevek és származási hely szerint az anyag így alakul:

\section{FÖLDIRATI FELOSZTÁS.}

1. Kiliti helység, Somogy m:

Mitók,

Kónyi, ${ }^{1}$

Mlózsá,

Fejér,

Juhász,

Nagy,

Kis,

Konnáromi,

Tót,

Póka.

2. Exuket, Sommegr m.

Mányoki,

Hekeli.

3. Zanírid helys., Somogy m.

Matyikó,

Halász,

Rezi,

Varga.

4. KöRöSHegY, Somogy m:

Nagy,

Sziver,

Bóka,

Dankházi,

Kocsonya,

Gyugyi,

Kaszil,

Pap,

Szita,

Kocsis.
5. Szárszó, Somogy m: Párej,

Maráczi.

6. Balaton-Csehi, Somogy megye :

Lukács,

Kocsis,

Aranyas.

7. ORda, Somogy m: Takács.

8. Balatón-Ederics, Somogy megre:

Osvald,

Farkas,

Tót,

Jóbbágy,

Kocsis,

Nénet,

Bogdàn.

9. Tördenicz, Zala $\mathrm{m}$ :

Kálmán,

Ravasz,

Gáspár,

Német,

Szabó,

Tót,

Német.

Kankó,

Vigánti.

${ }^{1}$ A felhúzott nevekre kiilön megjegyzús lesz. 

I. TÁBLA.
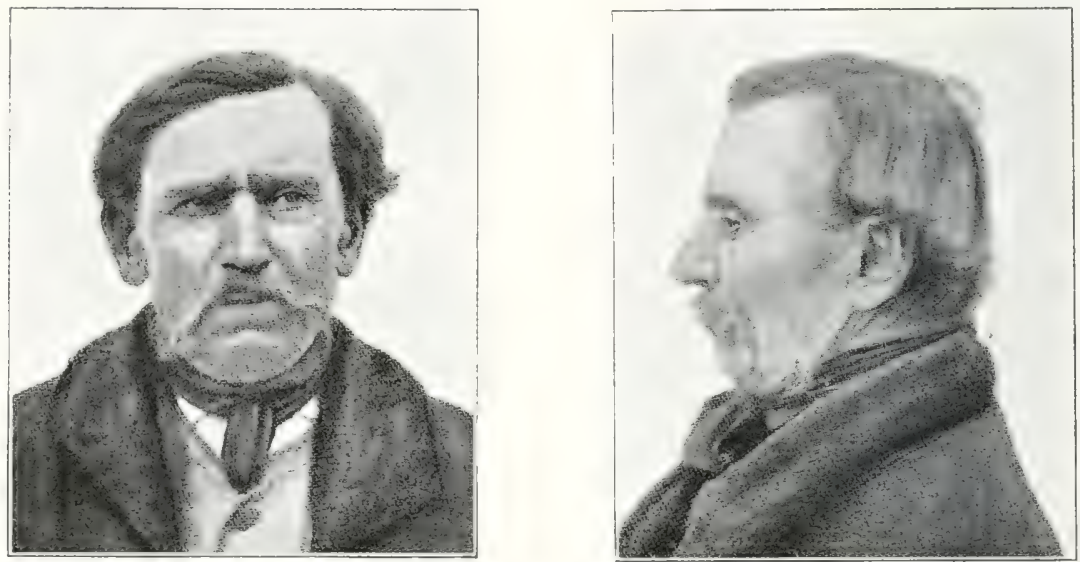

37. Xémet József (az elübbi apja), Tördemicz (Zalam., földmúves, 63 éves, haja gesłtenyebarna, bajusza szüke, szeme liék, sasorrú, termete $1738 \mathrm{~mm}$, a fej kerülete $552 \mathrm{~mm}$., a fej jelzöje $(158 \times 100: 184 \Rightarrow) 859$.

37. Joscph Német (Vater des No. 36.), Tördemicz (Com. Zala), Ackerbauer, 63 Jahre alt, Haar kastanienłraun, Bart blond, Augen blau, Adlernase, Körpergrösse $1738 \mathrm{~mm}$., Umfang des Kopfes 552 mm., Cephalindex $(158 \times 100: 18 t=) 859$
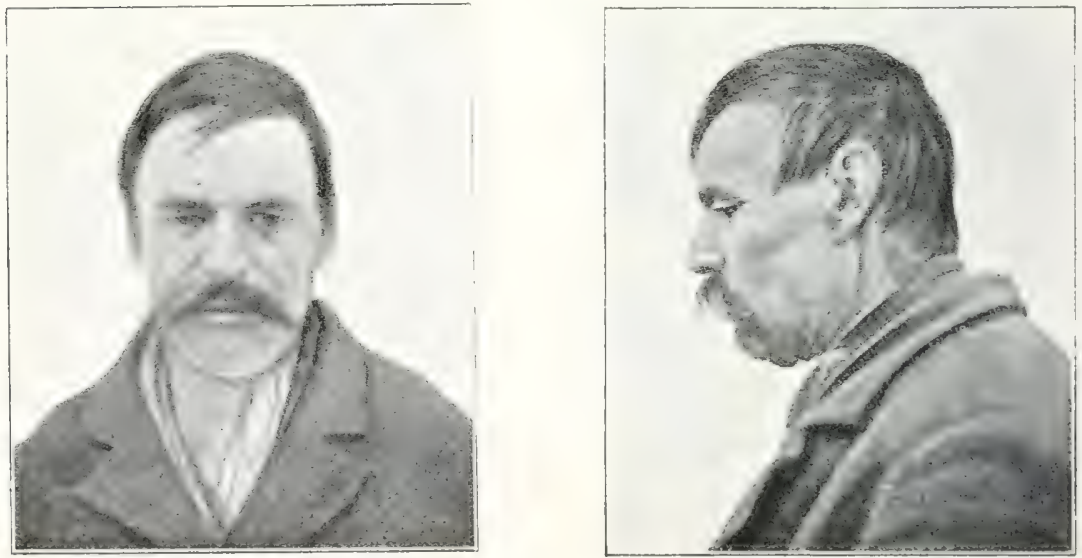

27. Paréj István, Szárszó (Somogyın.), földmüves, 58 éves, haja és bajusza gesztenyebarna, szeme barna, orra

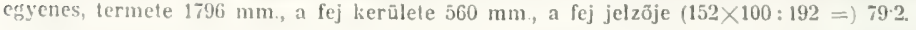

27. Stephan Paréj, Szárszó (Com. Somogy), Ackerbatıer, 58 Jahre alt, Haar und Bart kastanienbraun, Augen braun, Nase grerate, Körpergrösse 1796 mm., Umfang des Kopfes $560 \mathrm{~mm}$, Cephalindex (152×100:192=) 79.2. 

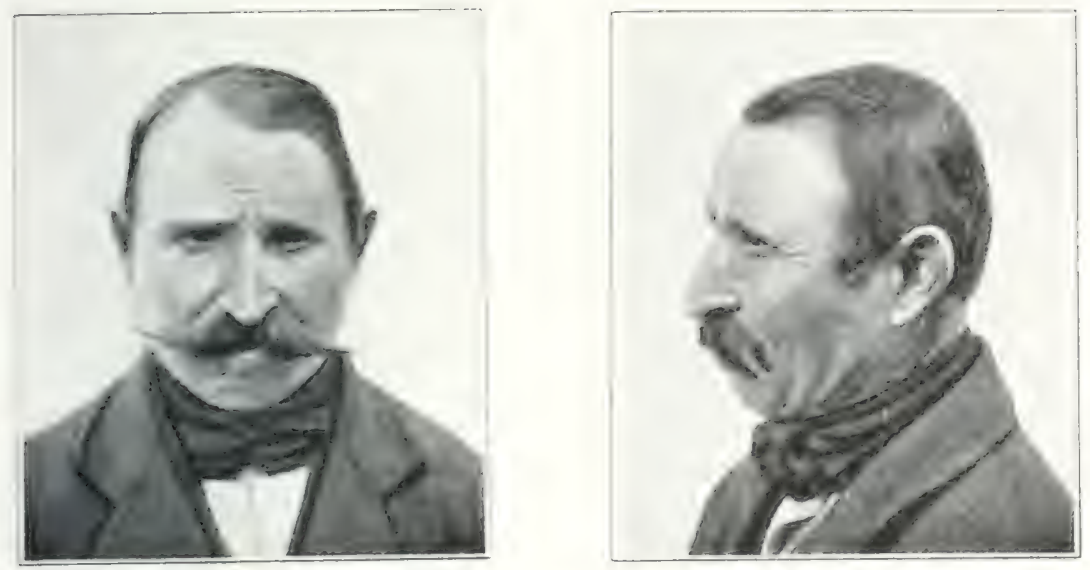

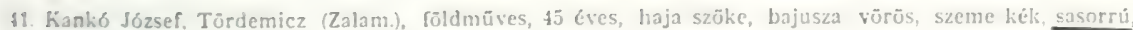
fermete $1550 \mathrm{~mm}$., a fej kerūlete $530 \mathrm{~mm}$., a fej jelzöje $(152=100: 180 \Rightarrow 81.4$.

11. Joseph hankó, Türdemicz (Com. Zala), Ackerbauer, 45 Jahre alt, Haar blond, Bart roth, Augen blau,

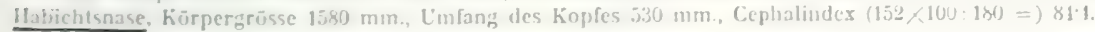



I1 I:4111 :
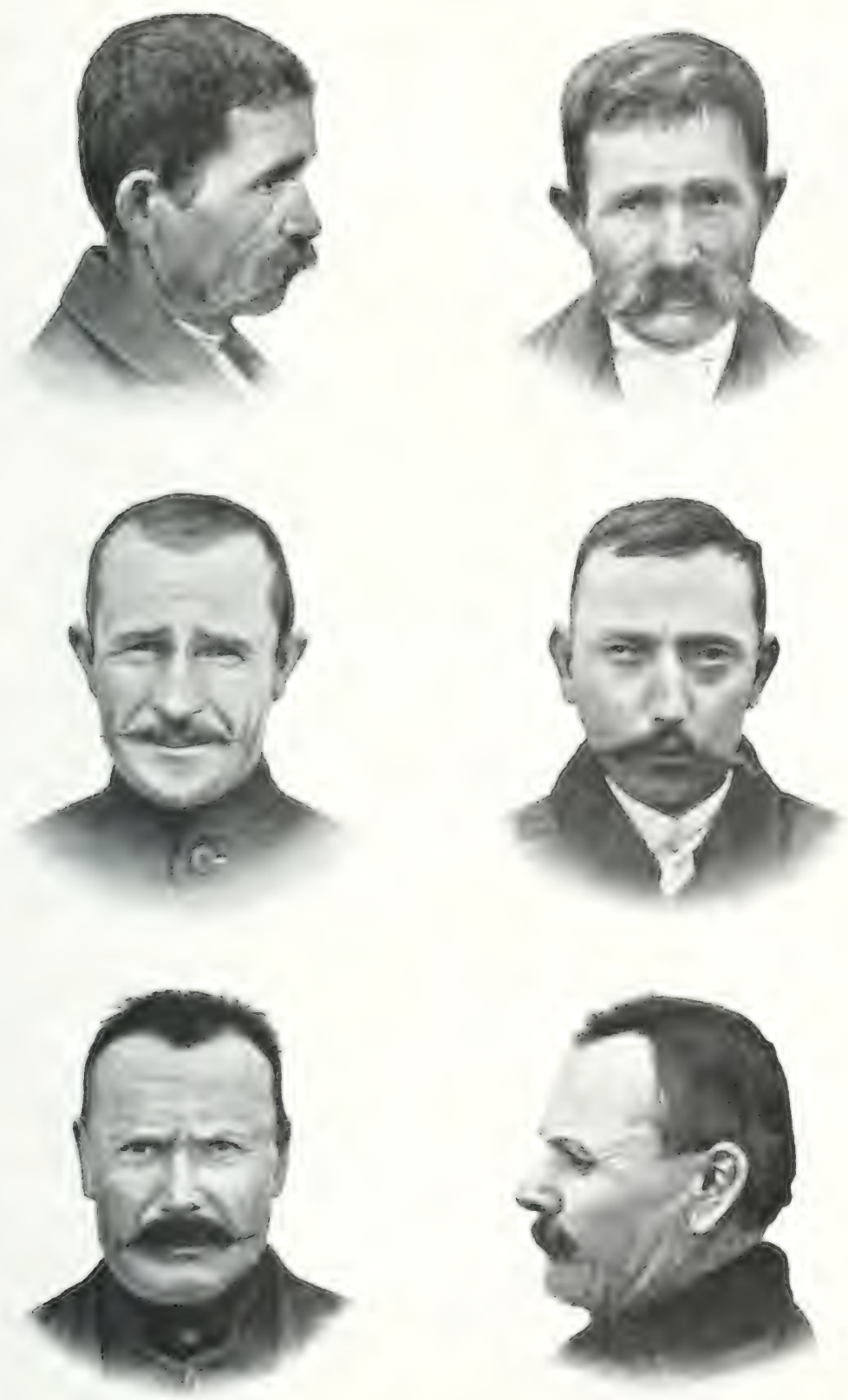

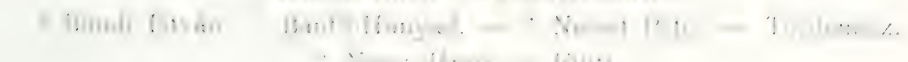

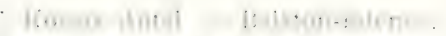

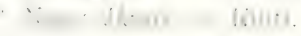





\section{A MEGKÜLÖNBÖZTETÉS.}

E nérsor maga mondja meg. hogy a dolgozatban ninesenek alkalmazsa azok a finomabb megkïilönböztetések, a melyeket hat pontban kifejteni iparkodtam és a melyek egyáltalában, de küilönösen ott, a hol egr meghatározott terïlet anthropologiai viszonỵairól van szó, nem mellözhetók.

1. Kihagyandók lettek volna azok, a kiknek családi neve nemzetiséget jelent, tehát: Német - 3-Szor - . Tót - 3-szor — mert ezek más számazásra mutatnak.

". Kihagyandók lettek rolna azok, a kilinek neve ¿z ország más területein fekvö helységektöl ered. igy: Lomáromi, Kányoki, Karáczi, Dankházi, Kónyi. mert ez beszámazásra mutat s e felfogás magyar füldön különösen indokolt; Bóka helység van Szerbés Horvát-Bóka megkülönböztetéssel.

3. Kihagyandók lettek volna a nyilván idegen nevüek mint: Osvald, Hekeli = Hekel; Sziver = Szilber: Matyikó = Matejkó; Bogdán = Adeodat, ab Bog és dan = Istenadta, szláv név.

t. Nines tekintetbe véve a köz-nemesi viszony, mely a magyar ösi és rendi alkotmanymál fogra a ..tipusra" nézve szerfölött fontos, mert birtokviszonyainál fogva helyluez kötött és ugyane viszonynál fogua kevésbbé vegyiilö volt.

5. Nines tekintetbe véve a jóbbágyi viszony, mely a nemesivel szemben a hódításnál és az alkotmánynál fogra más természetü, hozzá áramló és vegyiilö voli.

A negyedik pontra, a nemességre nézve figyelmet kértek már az ilyen nevek: Komáromi, Mányoki, Dankházi, - a „Jóbbágy" név - B.-Ederics felhírhatta rolna a figyelmet arra, a mit jelent.

A dolgozat szerint az egyének válogatásánál à 
rolt a vezérelv, hogy az illetönek családja „törzsökös“ és már a XVIII-dik században is helyt volt legyen, és hogy a kiválasztott egyénnek az anyja is „törzsökös magyar" lett légyen. Ám a "törzsökös" jelzönek megokolt allialnazásia épp oly nehéz, mint a magyarság anthropologiája maga; „csak úgy“ alkalmazva hangzik ugyan; de nem bizonyit, már annál a legközelebbi és igen egyszerú kérdésnél fogva sem: vajjon a választott egyénnek, leszármazása során, a XYlll-dik szátadtól kezdre minden anyja „törzsöliös. magyar volt-e?

\section{A MÓDSZER.}

Az elemek kiválasztásá1a nézve a kongresszusi kiadvány ezeket mondja: „Lithnogratiájuk egvséges s mai anthropologiájuk közös elemekből, azonos milieuben, " hasonló módon fejlödött".

Meg nem fejthetó azonban ebben az elvi kijelentésben, mit jelentsen szabatos fogalom szerint a „közös clem"; mit az ,azonos milien" és mit a ,hasomli mid".? Ezek nem lehetnek puszta jelzök; hanem alapos eljáras mellett isen is elözményeliböl levezetett tételek. Ám itt éppen az elözmények hiányzanak.

Különben az egész közösség, azonos milieu és hatsonlóság fölállitátsának a leghatánozottabban ellentmond Tördemicz falunak belevonása, mely a Balaton zalai partjának, legklasszikusabb, rulkanikus hegralaklilatanak, a\% egés\% Badacsony-csoportnak ,,milieujéher tartozik, mely földtaniląr meró ellentétje a somogyi alakulatnak, a melyen a többi választott falu áll.

1 Az ujabb magyar irodalom, nint mondani szokís, nagyon felkapta a „milicu" és a "jegsyben" szót. Mindkettónek a napisajtó legbuzgóbb alkalmazója és terjesztöje. Ez meg az, ennek meg annak „jegyében áll, történik”, ilyen és olyan ,milieuben". Ott, a hol tudományos szabatosságról van szó, ilyen határozatlanságnak nem lehet helye. 
A kongresszusi kiadriny beve\%etése nem tanit meg ama: mi okolta megr azt, hogy a mespei határon jekvö kiliti-böl ts közuil 10 ember mint jellemzö

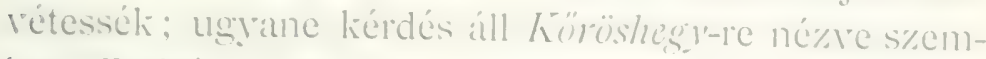
ben Endrid" és ()rda l emberérel?

A Ballatona né\%ve mindenesetre áll a\%, hogy oly határo\%ott természetü és hatalmas földrajzi eğłsége.

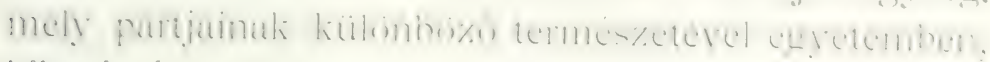
kiható és anthropologiali alakulásolía is, melyek a parti viszonyok küilönbözöségénél fogra nem lehetnek egységesel: e\% a viszony az anthropologial meg-

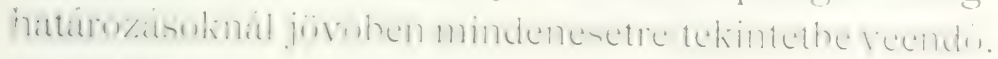

\section{A BIRÁLAT.}

Lássuk és itéljük meg most már a kongresszusi liadvány arczlépeineli némely részét.

Az egés\% alkalmazott módszert kifejti az I-só és I. -1) táblának hat páros képe, mely három férfit a már jelezett szembe- és arczélállásban ad és a mely

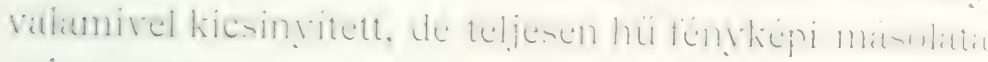
“ kongresszusi kiadvány illetö képének.

Már a futólagos általános szemle is azt mondja nekünk, kik a magyar arczulatot - ha csak, ösztöns\%erüen" is - ismerjük, hogy ezek a férfiak .ross\% arczúak". A második benyomás a\%, hogy nem is három férfinak kettös, tehát hat fölvétele, hanem öt férfinak hat felvételével van dolgunk, axért, mert csupán az I. -t) (41) KANkó JózseF arcz-és arczél-fölvétele

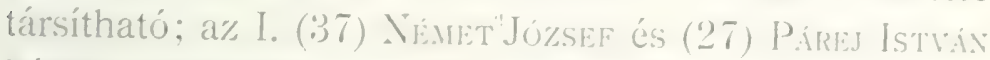
képe egráitalában nem társitható és teljesen a\% a benyomásunk van, hoģ az arčban és a\% arc\%élben felvett arc\%képek küilön-külön, más-más férfit ábrázo]nak. A különbséget a\% okozzá, hoegy a felvételek más-más világitás mellett, küiön beállítással történ- 
tek, miközben az illetö férfi más arczkifejezést is öltött.

A hibás világításnál fogva (37.) Német József arczfelö] még sötét hajzatú, arczélben már ơsz ember. Igen nevezetes ugranennek a\% arczképe mimikai szenpontból. A teli arcz- — en face - kép szeme szerint teljes meşfelelöje a Duchesxe-féle mesterségesen elöállított síró arcznak, melyen mind a két arczfél a sirasnak más-más fokozatát mutatja; a jobb szem az erósebb, a bal a mérsékeltebb sírást. Duchenne ezt a sirási felemás-képet vagy arczot a kisebb járomizom — 8. kép F - és a tulajdonképeni emelö felsöajakizom - G - elektromos ingerlésével érte el. ${ }^{1}$

A különbség azonban igen lényeges; mert NéMET JózSEF arczán csıpán a szem alakult át a külsö inger folytán, a säij nem: pedig ennek kölesönös alakulása nélkiil az arcz nem öltheti a sírás teljes mimikai kifejezését, a melyet e könyv "A sirás" szakaszából és képéböl - 19. kép — már ismerünk. NÉmet

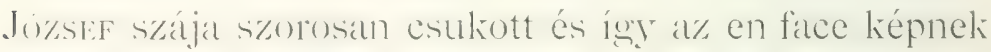
inkább az, ,eróltetve elfojtott sírás" kifejezése van.

De ez sem igazi mimikai alakulat, és éppen azért a megitélés ingadozóví vilik. (rondolunk kénysiene. rossz kedvre, vagy valamely az egyén természetében rejló tulajdonságra. Majd megválik.

A társítható I. A) (11) ar’czkép, Kankó József, szeme

I Duchenve i. h. IX. Muscles du pleurer et du pleurnicher (petit zygomatique et elevateur propre de la levre superieure).

Fig. 47. Destinée à étudier l'action differentielie du petit zygomatique et de l'elevateur propre de la levre superieure chez le même sujet.

'A ganche, excitation électrique du petit zygomatique et contraction volontaire du sphincter des paupieres: pleurer franc, i chandes larmes.

' $A$ droite, excitation clectrique de l'élévateur propre de la levre supericure et contraction volontaire des paupières: mance de mîme pleurer. 
szintén rendellenes tekintetü, a hunyoritás folytán a szarkaláb-ranczozat nagyon szembeszökö, a s\%enkö\% crös, meröleges ráneza, at homlok harántránczozata. a száj tájanak kemény kifejèése eszünkbe juttatja, a tudikios. pörlekedö ú. n. queruláns embert. Pedign épp oly lievéssé a\%, mint nem síró Ne.uet Jozser és nem sunyiskiodó 1. (27) Pikes IsTrix.

A triba a fülvételbe'n ran.

\section{A HIBA.}

Nár a történelmi részböl, Piderit múvének méltatásából, ismerjük azt a tételt, mely a szemnek külsö

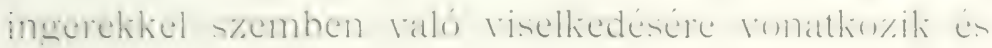
igy hangzik:

. Nagyon kellemetlen behatásoknál, küiönösen whiur. hat azok hirtelensersed köretleztek he, a szem erösen hunyorít... hozzáteszi Piderit, hogy ily enetekben at -\%em esilk ritkin zilrul be exés\%en, mert ckkor elveszne at vedö isckkiés lehetósége. Tovibbi. hogy a látást hirtelen támadó behatásnál fogva a -zem redözertiezete azonnal es mintegy öszünszerüleg müridésbe jön és igy. mielöt més at vesedelnet felfoghatnók, a szem már védve van. Végre: „Ha a szemet hirtelenül támadó vakító fény éri . . . a homlok böre az, mely meróleges ránczot vet, azaz: a szemöldököt összerántó izom - - 8. kép M. - meg-

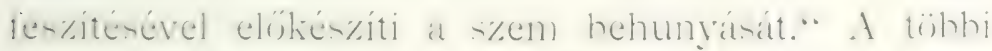
a szemkörizomzat - 8. kép B. C. E. - dolga.

Ugyanez az élettani folyamat áll be abban at perczben is, a melyben a szemet a napfénynek kiteszszük. A szem ekkor azt a\% alakot ölti, a melyet ¿ 3 t. kép tüntet föl. ${ }^{1}$

vette foil.

Ezt a hitünõ, ritka rajzot Koszkol Jenő a Nap behatása alatt 
Az arczképek tehát napfényben vétettek fel.

De honnan van az, hogy e képek szeme még: sem felel meg egészen a 34-dik képnek?

A mily egyszerú az c kérdésre tartozó felelet, oly érdekes és messzevágó is. Ezeknek az embereknek a fölvétel pillanata elött azt mondták: „nyissák

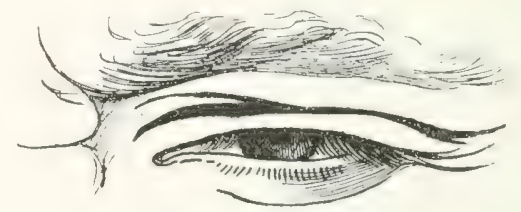

34. Hunyoritó szem.

ki s\%emüket, tekintsenek nyájatsan!’ Ninthogy azonban a Nap vakító hatalma evvel ellenkezett s az emberek mégis engedemeskedni akartak, crölködtek és a az erölkëdés kïlünfëleképen duilta fel az ariz vonásait.

Itt tehát nem tiszta élettan-mimikai folyamattal, hanem khatotikusan egrmást zavaró, ösztönszerü és tudatos mozzanatokkal van dolgunk, a melyeknek tüzetesebb méltatása majd még következik.

Itt még csak azt kell érinteni, hogy a hunyorítás mimikája könnyen átmegyen és rögzoödik az arezulathan, részben látási hibából eredve, de lestöbbször azoknál, a kik hivatásuk ragy temészeti riszonyok folytán tartósan, vagy bizonyos állandósíggal rakító behatásnak ki vannak téve.

$\mathrm{Az}$ utóbbi sorhoz tartozott az a lapp ember SvédJemtlandból — 35. kép -, a kit úgy a hogy levízoltam. Xagyon valószinü, hog̣ a hó vakitó fehérsége megtette azt a hatást, hogy a szemhunyoritás arezulativí vált. Megjegyem, hogy a lapp gyermeliek nyilt, ćlénk tekintetüek voltak és esalk a koros embereknél mutatkozott a hunyorítás és vele járó ráncz- 
letés allandositgar. A rendes magyar atrezok rendén

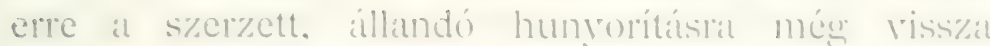
lugumli térni.

A teljesség régett álljon még itt a\% is, hogy at kongresszusi kiadrány atrezképei kïzüll nemesak a\% itt

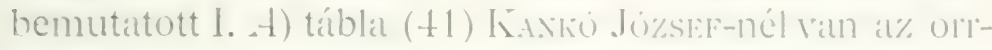

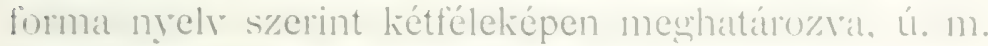
..sas orr = Habichtsnase", hanem ugyane\% at hihat

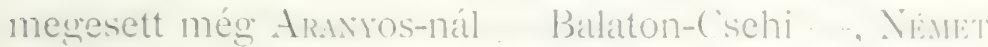
PETrR-nél - 'Tördemič - és Osvatu-nál - Balaton-

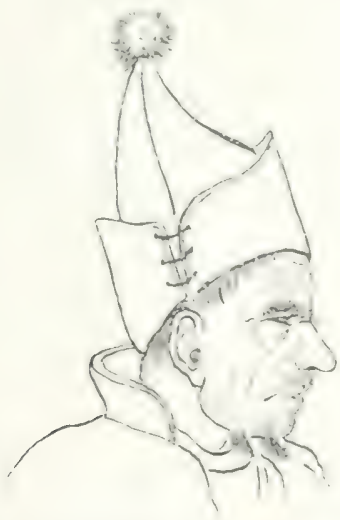

35. Intlandi öreg lapp.

Ederies - ; ezek különben valamennyien nem tipikus. de mégis közel "héjjaorriak".

Hogyha most a második sorozatráa -.. Il. tábla retjük pillantásunkat, úgy itt is a\% elsó benyomás a "rosszarczúsáğ".1

A legfelső két kép Kocsis Antalć - Balaton-Edericsen face és en profil. Ez a kongresszusi kiadrány̧ban ¿ $\$ 6$-ik arczkép; orra mint "héjjaory = Habichtsnase* van mondva, pedig orra tipikusan "egyenes". A\% ember rannak.

I A -gal jelzett képek a kongresszusi kiadvanybril valrik és kicsinyitvu 
a Nap vakító hatása ellen nem hunyorítással, hanem a fej lesütésével védekezett s ez adja arczának azt a sajátos kifejezést, a melyet mi magyarok népünknél a szenteskedo", kéreget" és olyan ember alatt értünk, a ki "jobban reszket, mint a hogy fazik." Pedig ez is csak látszat, mert a vakítás, az ez ellen való védekezés és a felvevố biztatása így dúlta fel a vonásokat.

Böndi Istrán, Bánffi-Hunyad, a ki már a konurresszusi kiadvány iskolájából való ${ }^{1}$ s a kit mint kiválóan jellemzó hunyoritót vettem át, mihelyt szaját és allat elfedjük, szeme szerint tipikus Duchenxe-arez, „forró könnyeket ontó", mihelyt a szájat és az orcza ranczozatat is szambaresszül, a mimikai benyomás legrinkább a "vigyorgó hülyeség" benyomását teszi.

E mellett NéNet Péter balra görbült orral és kifelé Kancsalító jobb szemmel semmiképen sem foglalhat helyet ott, a hol egy adott nemzet rendes és jellemzó anthropologiai arczképeiról — a szó tudományos értelmében van szó.

E II. tábla legalsóbb képe NAGY János, Kiliti, az en face kép vakitás következtében teljesen f’eldúlt arczronásokkal, szem szerint I)UCHENwe-arc\%: az arc\% alsó felének hozzáadásával retekedik az elözörel: az arcz-él képen a dúlás a szarkaláb-ránczozaton s az orczáién látható leginkább; pedig bizonyos, hogy helyes fölvétel mellett arczban és arcóélben kitünö. magyaros tipus-képet adott volna.

Az arczképeknek az a sorozata, a melyet a III. tábla egryesit, elsö pillantásra csakugyan azt a benyomást teszi, hogy csupa s\%emens\%edett gonoszteröarezot nyujt a tárgyalás és meghatarozás alapjaul, 

111. T.ina.
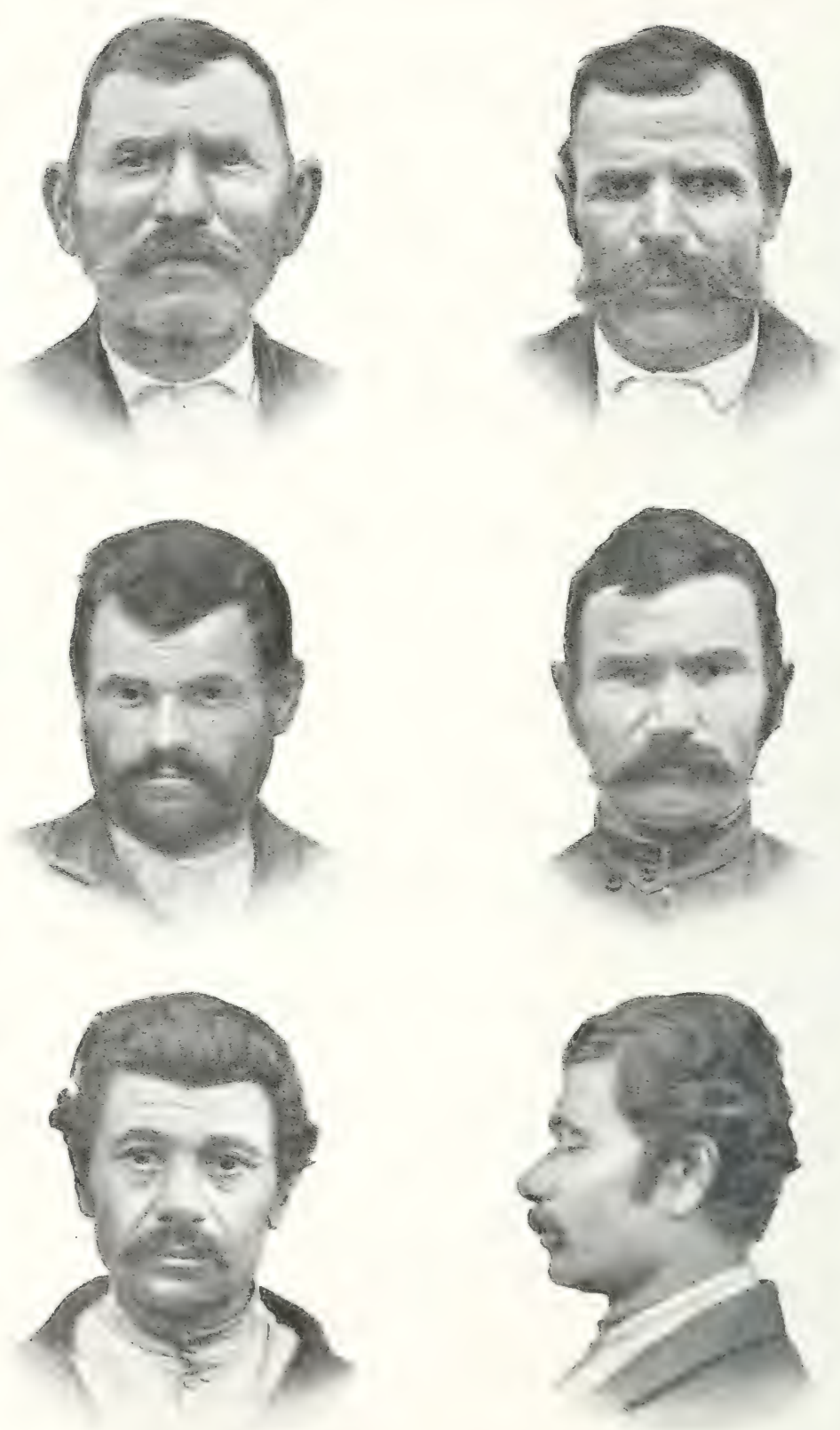

- Fojér Györogy - Kiliti. lovere Fierenc\%.

- Vigánti József - Tördemicz.

- Szita Andrís - Köröshegy. 
[1. T:IBBA.
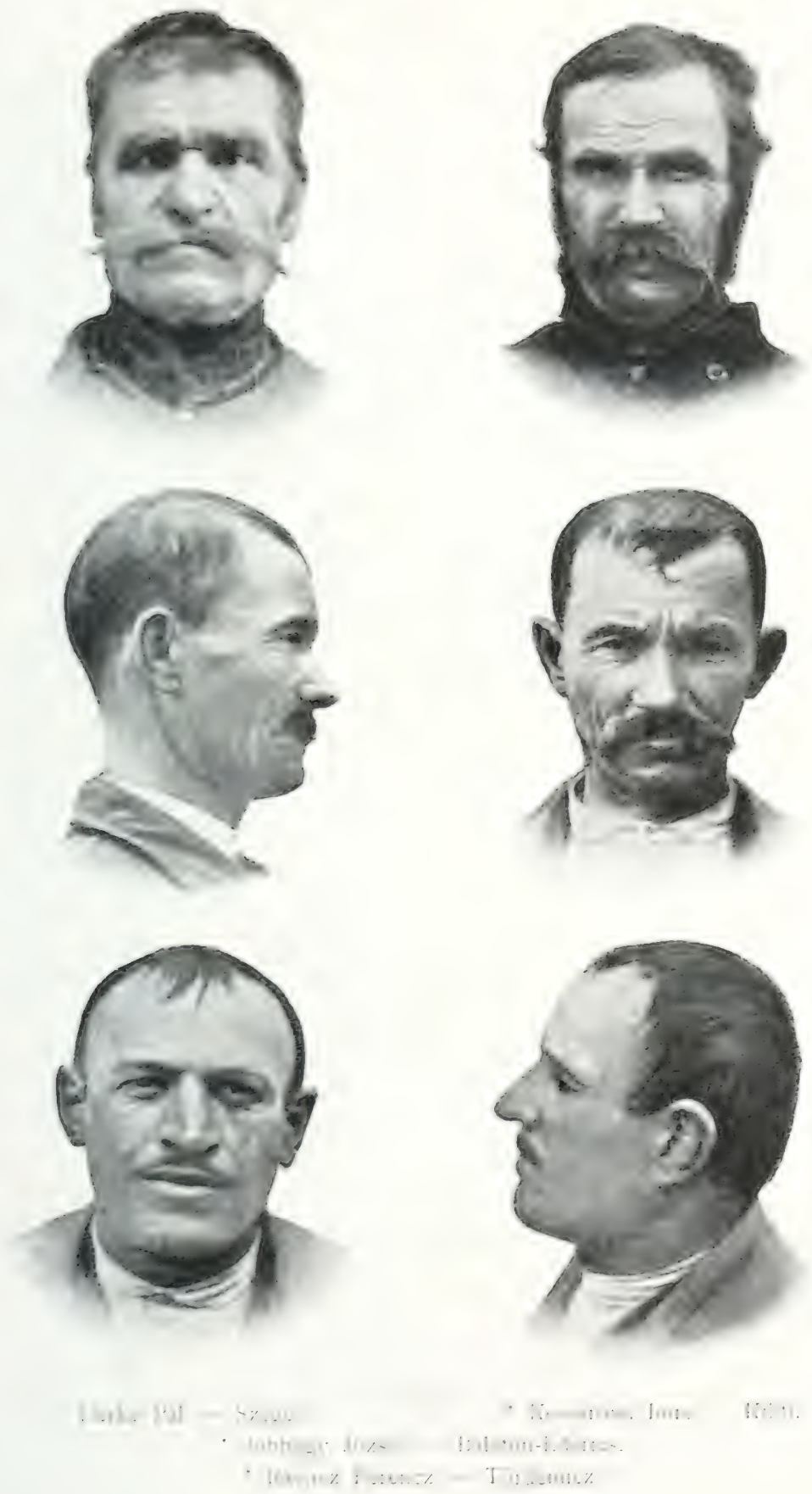

egrotöl-enyig ama valót, hogy Lombroso Cézar közkeletï. söt szilló igévé vált tételeit igazolja.

Mál pedie a Ill-ik táblán csak egy gonoszterö arc\%liépe ran tudatosan elvegyitre, a LOVREz FERENCz-é, a ki elöre eltükélt szándékial orozva gyilkolta meg áldo. zatat s azután szétdarabolva megfözte. A förtelmes büntett Ausztriaban és napjainkban történt. Ennek az emberi szörnynek arcza csak szakállas voltával rí ki a négy becsületes magyar emberé közül, a kiket az juttatott társaságába, hogy a fölrevó nem tudta biztositani a szem ny̆ugodt, normális kifejezését, igy a ..lélek tükrénel-" hüségét.

Szegény kiliti Fejér Grörgy - - III. tábla, elsó alak - a szerencsétlen fölvétel után válik, ,született

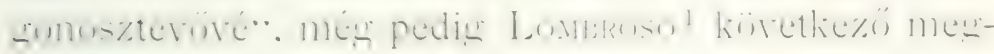
határozása alapján:

A születettgonoszterö:

Fỉile: elálló.

Haja: tömött.

Allkapocs: roppant.

Pofacsont: széles stb.

Ezt még öregbiti az, a mit Lombroso külön a grilkosról mond, a mint következik :

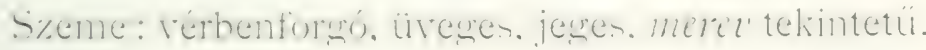

Orra: nagy.

Allkapocs: csontos, erós.

Pofája: széles stb.

A Fejér melletti arczkép Vigáxti József uramé. Turdemiumal és a zerene-étlen felvetel folytim. mely

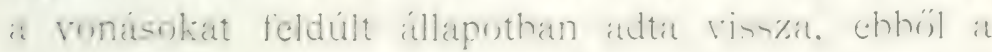


hecsületes emherböl a maysar hammin tipusat alliotta mes. a mint e\%t majd mindját közelról is látni fogjuk.

Ugyanezt a magyar haramia-tipust tünteti föl körishegri szrT. AxIn.sis man ugyanazoknal atzokoknál fogva, holott szárszói Maráczi Józsep, ki arczot és arczélt mutat, mind a két felvételben más-más anosztevö-tipust jelent, ú. m. arczban at merer tekintet. arczélben a lesütött szemmél fogva; ezekhez hozzájárulván még a sürü hajzat és az alacsony homlok is, a vastag orról nem is szólva.

Részletesen véve, szembeszökő az egyezés a homlok harántránczozásában, mely az orgyilkos Lorreznél is megran, a becsületes magyaroknál javarészt a felvétel következménye és hogy valóban ez az ok, azt minden kétsézet kizaroan bizonyitja a magrarok arczának kifejezése, mely eröltetésröl szól.

A következó IV-ik táblával bevégzödik a kongresszusi kiadvány kellemetlen birálata.

E IV. táblára vetett futó pillantás azt a benyomást kelti hennünk, hogr a hemutatott négy atrezkép közüil, csupán a kiét felsö magrar emheré, a középsó és alsó arcz- és arczél-fölvétel nem is lehet az.

A legelsó helyen álló arczkép Herke PÁl, a RózsA Sixurr-féle haramiabandának ij éres .postusa", hirszerzője és hírvivője. Ez magyar értelemben véve kiasszikus Lombroso-tipus, hi a kancsalság járuléhítral Lombroso két gonoszterö-csoportját összehöti, ú.

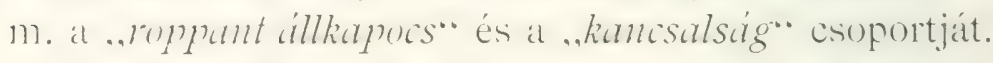

Ez az arczkép jó, vonásai a fölvétel módja folytán nincseneli feldúlva s így az, a mi a ránczozatból lathato, megrögritett. fiziognomikus járulék. A s\%emkii\% hatarozott meröleges redoje ragr ranczat. melyet az orrtó harántráncza még erósít is, a mélyen fekvö 
szemnek hiváloan sötét tekintetet kölesönöz: at stáli

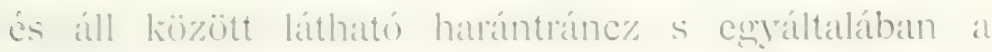

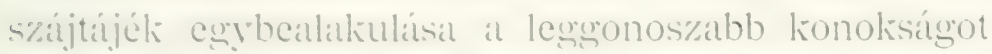
jele\%i s a fogak hiányar e\%t a ronást még élesbiti. usyanezt teszi a homlok harántráne\%ozata is.

A szerencsétlen fölrételek Vigixr, SzITA - III. táhlat - - itt a 11 . táblán kiliti Komárom LMre uramat HERk: Pil. társaságábal keverik, holott szakértó telvétel mellett nagron messze esnének a magyar lovasbetyár tipusától.

A IV-ik tábla köretkezö alakja balaton-edericsi Jorbigr József, mely elálló füilével, a jobb arczfél

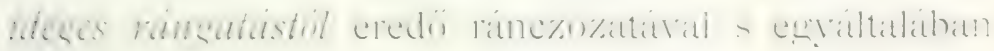
¿z arczronások teljes feldúlásával az alkoholizmus tipusát állítja elénk, öregbitre a szemköz erös, meróleges ránczozatával, melynek eredete - mint már tudjuk is - a vakitó napfénynek a felvételnél való hatásától ered. Ennél az arczképnél a két felvétel fedi egymást, vagyis társítható; de mind a kettó egyformán a ,rosszarczúság" benyomását teszi, élénken

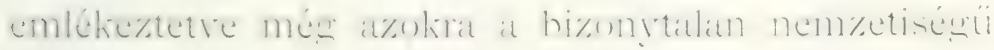
beszármazottakra is, ú. n. ..kucséberekre“, a kik itt magrar földön eliszákiosodnak.

A sorozat utolsó alakja tördemiczi Ravasz Ferexc\%. kinek arczfelöli képe minden vonása szerint - nem kis részben a szemkifejezés feldúlt volta folytán azt a tipust ábrázolja, a melyet a rendörség és közfelfogás a ,betöröh" közé sorol, oly jelzóvel, a mely

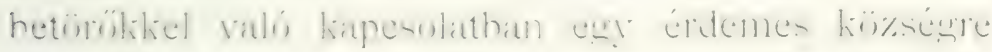
nézve határozottan sértó, a melyet tehát mellöznöm kellett. Az arczél ralamivel enyhébb.

Evrel régződik az 1900. évi kongresszusi kiadvánỹnak méltató és biráló szemléje, a mely bizo- 
nyáa meggrözött mindenkit, a ki e könyvet eddig figyelnérel megajándéliozta, arról, hogy nagyon sajnálatra méltó dolog volt ezeket az arczképeket, mint , magrar tipusokat" világraszóló alkalommal és éppen akkor a világ tudományos körei elé terjeszteni, a mikor az elismertetésért való küzdelemben a magyarsigg gyözött és mindenki érdeklödött az iránt: mi legyen e törekrö, nemes faj anthropologiai arczulatar.

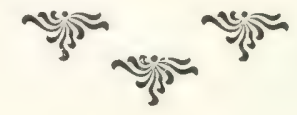




\section{AZ IGAZI MAGIYAROK.}

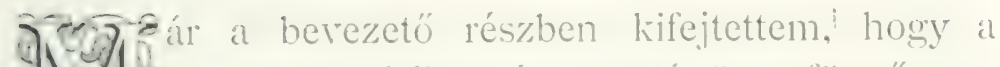
13 somatikus faji leszámaztatás összefüggó, szaL Kadatlan sorát és egymásutánját biztosan megullupituni nem lehet in hogy mindakok at aldepoli.

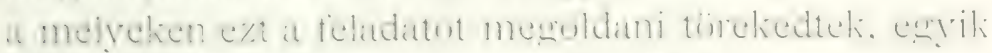
mey ma-ik tekintethen ingutuguk. Sem at hatyromany. sem az üsrégészet, sem a krónikák sora nem nyujt elégrgé szilárd alapot arra, hogy a faji alakulást eredettól fogra, vagy báresak a multnak valamely kimu-

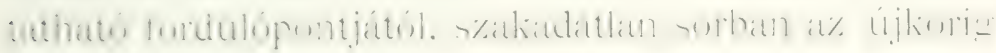
biztosan levezethetnók.

\section{VÁMBÉRI ÉS HUNFALVY.}

Ezt a tételt legjobban megrilágitja és bizonyitja a\% a\% egr'mást kizáró ellentétes álláspont is, a melyet at masyarság leszármazásának két legelökelőbb mestere a kérdésben elfoglalt és a tudás leghatalmasabb fegrvereirel vitatra, érvényesíteni törekedett.

A két vitató nem kisebb ember. mint Huxfalir Pit és Vanbéri Ámur.

Vimperr ezt a\% ellentétet kiváló müvében, mely a

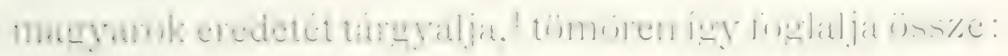

.HLNFALiY a magyarokat finn-ulgor néptörzsnek tartja. mely a\% ugor népek területének déli és délkeleti csúcsán, a törökök közvetlen szomszédságában 
lakott és az ezekkel való hosszas és benső érintkezés köretkeztében, a török befolyát praegnans nyomait viseli magán."

„VÁMBÉRI éppen megforditva, a magyarokban török néptörzset lát, mely a török-tatár népelem északi és észak-keleti határain, az ott egymással határos ugor népek területének érintkezô pontján levö örszemkép lakott és ugyanabból az okból, a melyet Hunfalvy feltesz - hosszas bensó érintkezés — az ugorokkal való érintkezés mélyreható nyomait mutatja fel".

Természethistóriailag fegyelmezett agyú ember elött, a mennyiben ide a\% embertan is tartozik, az ellentétet illető kérdés az: A magyarság így vegyes elemekböl alakult faj lévén, ebben a fajban a történet eifogradható sorának és a mai éló bizonyitékoknak tanusága szerint, rajta a török vagy à fmm-ugor tipus uralkodott és uralkodik-e kiválóbban?

És továbbá: vajjon a fmm-ıgorság bizonyult-e allamalkotó, allamfentartó elemnek, horza olyannak, a mely minden lesyörött, meghóditott törsirokont. vagy hozzá csatlakozott idegren elemet a maga képére átformailt, beolvasztott, uralmának alávetett, aragy a török elem bizonyult-e ilyennek?

És végre: ha az egész psychikai és ethikai készséget veszszülk szemügyre, a mely a magyarságnak aranylang lesklevésbbé érintett rés\%ében, szemlélödése és cselekvése képében még ma is él és lüktet, vajjon inkább fimn-lıgor, vagy török jellegï-é ez?

\section{VÁMBÉRI TÉTELE.}

VÁMBéri Áruin igy foglalja össze a legtömörebb formában a magyarság diagnózisát.1

1 1902. aprilis 17-én kelt levelćben. V. ö. VẢMBÉri Á. „A magyarsíg keletkezése és gyarapodása“. 1895. 
.. matrar nemzet nem directe Azsiából søármazik. hanem én olyan vegrüléknek tartom, mely fimn-türök is salin elemekböl itt Pammoniaban lieletkezett. At test pusatul, de a lélek megmarad.' A marraban kevés ar ural-altai faj somatilius tünete: de annál több a psychilial sajátság, ment mint lir és paramisoli ringomita saellemi bélyegét az ciltala megJivititot népelemekri". A tétel elsö része vitatható.

Rögtön fölvethetö itt à kérdés, vajijon az, a miben linber diagnózisa kicsúcsosodik fimm-lyor vagy török jelleg-e :

De hagyjuk, mert ismernünk kell elöbb azt, a mit limber idézett múvében - pag. 451 , $45 \overline{\text { és }}$ t5் - aról a megmaradó „magyar lélekrool" már ezelött húsz érvel mondott, a minek uralkodó és alakitó hatalmat tulajdonit és a mi tömören összefoglalva a következö:

.A legnagyobb figyelmet az az ellenállás érdemli, a melyet a magyarok mindenkor azokkal a\% intézkedésekkel szemben kifejtettek, a melyck a magyarság erkölcsi átalakítását czélozták, más s\%avakkal, a melyek a magyarság erkölcseinek, szokásainak. régi tiszteletreméltó intézményeinek, s\%óval valódi szellemének megtörésére irányultak. A kifejtett nagy, mondhatni szent buzgalmával, a magyar minden ázsiai testrérét és törzsrokonát összevéve, hatalmasan fölülmulta, hatalmas, megkapó nemzeti önérzetet bizonyitua be."

„,Magának a kereszténységnek másfél század kellett

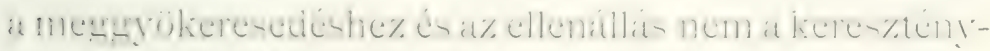

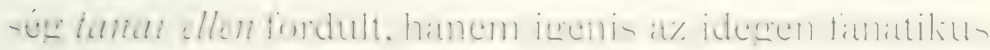

1 V. ̈. a bevezetéshen a psychikus sor szakadatlansígáról mondottakat és Alexander Pernát szavait u. o. 
téritök ellen, a kik a magrarsagot nemaetségéböl, "osi sulditsigriból kiforgatui törekedtek és semmi kétség, hogy ha az idegen térítók czélt érnek, a magyar elenvészik és beléolvad az öt körülvevö idegen tömegbe. VATA és Kupa lázadásai ezt jelentik tulajdonképen“.

,A nemzeti egyéniséghez való szeretet és ragaszkodás, a mivel és a minóvel semmiféle, az ázsiai puszák világuból Azsia vagy Furópa müvelt vidékeire került nép ki nem tünt, mint éppen a magyar, a mely népben ez a szeretet és ragaszkodás csodálatosan egész a mostani korig élt; söt a mely a nagyon megrailtozott ethnikai és társadalmi alakulás mellett is ugyanoly erejünek bizonyult és ugyanazt a sikert szülte: ebben rejlik ma is az az erkölcsi erö, mely a honalapitó magranokat besnyökön, kúnokon, kazárokon és a többi törzsrokonon és idegenen gyözelemre ritte és Pannóniában uralkodóvá tette; ugyanez az eró az újkor magyarjaiban is a szám szerint erősebb szláv, rumun és német elem közepette, ezer év multán gyöngíttetlenül tovább él"،

,,Az államalkotó erót ugyan más török-tatár nép is birta, de az államfentartás hatalmát egyediil a magyar tartotta meg".

VÁmbéri-nek ez éleselméjü fejtegetése tökéletesen helyreállitja, legalább is a honfoglalástol kezdre, psirchikailag és ethikailag azt a szakadatlan sort, a melyet somatice vagr mondjuli grenetice hiztosin helveatlitani ismereteink mai magastatán képesek nem vasurunk. mert hiszen azt egy irány vagy iskola sem vitatja, hogy a magyar abszolut faji nép, ellenkezöleg bá mals-más äsizetételhen ragy somendhen. de elismeri. hogy az több elemböl alakult.

Az azonban kétségtelen, hogy abból az összeté- 
telböl hatairozott egrónisége fejlödött, a mit majd at fellemray bi\%onvitani tarto\%ile és bizonyitani fog is.

Nair most hi ismeri el at finn-ugor elemet mint malyarar értelemben rett államalliotót, államfentartót a múltban és bizonyos erkölcsi tényezök közbenjöttével napjankign is: En nem. laumér éppen nem. ES PALLER GILLA is erós alapokial fölépitett történeti mülében, mely Matğaroršángot az álpádházi királyok alatt táloğalja, I’imber felfogását követi.

A fölött vitathozni, hogy vajion az eredet szerint török népet at tinn-ugor hozzájárulás tette-e magyarrá. államalliotórá, vagy megforditra, az eredetileg finnuxor népet a töröliség hozzájárulása : ezt sem a\% anthropologia méró szerszámjával, sem a történetírás ingado\%ó forrásaival tisztázni, vagy éppen eldönteni nem lehet: ahhoz csupán egyetlenegy út vezet: az az erkölesi, ethikai, psychikai szakadatlan sor, mely-

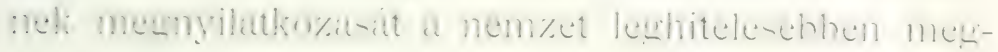
bizonỹitott multjában nyomról-nyomra követhetjüik. mely megnyilatkozott mindenkor, valahányszor a nem-

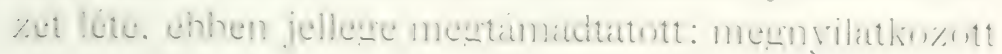
cselekioó. megnyilatkozott szenvedó ellenállással és ha ideigróráig le is tepertetett, mint az ó-világ félistene, az anyaföldtöl, melyre rogyott, kölcsönözte a\% erót a föltámadáshoz. Eddig ez igy volt.

Hogyha most már annak a szakadatlan psychikai. erhölcsi, ethiliai tartalomnak, melyet I'A.MBÉri oly mesterilegr meghatározott, anthropologiai arczképekben kifejezését keressük, ezt megállapitani törehszünk. ưgy ezt csupán abban kereshetjük, a mit MANTEGAzzA ,omimikai központnak". PIDERIT és mások a ,lélek tükrének" nevezteh, ez pedig a srem tekintete.

A szem kifejezése mellett a többi mimikai. fizio- 


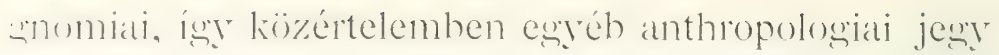
leginkább csak járulék, a melynek mérésekkel és vis\%onyitasokkal, képletelibe foglalásial, minden anthropologiai értékét ki lehet mutatni, kivévén egyet, azt hogy élet és lény szerint föltétlenuil magyar.

Íme ez bóvebb kifejtése a 6-dik pontnak azok között, a melyeket ,A meglevö anyag" czímü szakaszt megelözőleg, mint a tipusválasztás föltételeit felállítottam.

Ezentúl meg kell kisérlenünk a magyarság társádalmát tagozatai szerint részekre bontani s e részek anthropologiai értékeit is megállapitani.

Azt eleve is nem tekintjük, hogy a magyarság Pannoniába mint vad, vagy félvad törzs förgetege tört volna be, melynek léte a rabláshoz, a prédához volt volna kötve. Hogy ezt teljesen elejtsük, ehhez

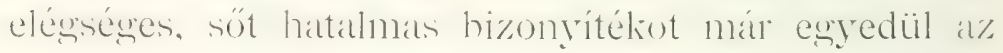
is nyujt, hogy a terület elfoglalása után alig másfél századdal, a királyi alapítványok és donatiók tanu-

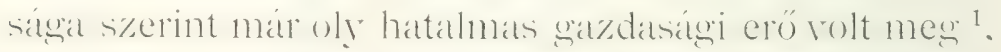
kïlönösen az állattenyésztés bámulatos arányaiban. a minöt félvad, müveletlen rablónép ily arasznyi idö alatt és akkor, a midön a gyors fejlödésnek minden föltétele hiányzott, ki nem teremthetett.

\section{VOLF GYÖRGY.}

El kell tehát fogadnunk azt, a mit oly korán elhunyt kulturhistorikusunk, Volf Györgr, a Codexirodalom és s\%okincsének legalaposibb ismeröje, mint alapos tanulmányai eredményének negyedik tételét, tömören kifejezve, igy állapított meg:

"Az erre vonatkozó bizonyitékok az "Ösfoglalliozásokrol" készuilö nuvemben, melynek erre ronatkozó grazdag anyaga együtt ran, fognak megjelenni. 


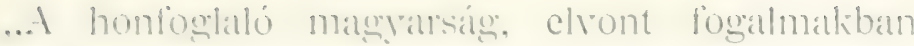

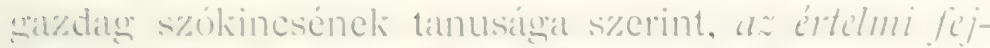

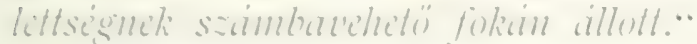

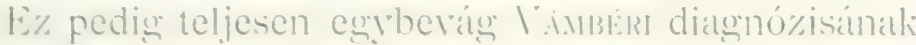

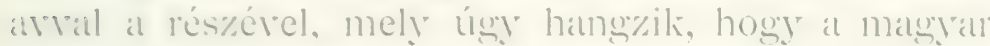

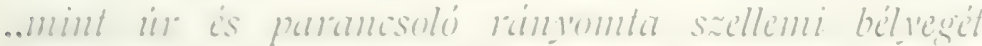

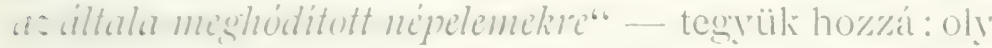
allimnfentató sajátságok és tulajdonságok erejénél towar, a melyek mind e mai napokig saakidatlan sorban liveazethetök. Ezt majd a könỵt II. részében meolátjuk.

Ha mál most mindazt egrbefoglaljuk, a mit a lonf Grörcir tételéböl, megpótolva a bö forrásból meritett I'AnuÉri-féle diagnózis értelmi részérel, logikailag kifejthetünk és a mit a ma élö szinmagyarság ex́észen sajátos tulajdonságaiból biztosan követlieztethetünk - szem elött tartva küiönösen azt, hogr e színmagyarságnak az ösfoglalkozások terén oly s\%errezetei és alkotmányszerú berendezései rannak, a melyeknek éló analógiáit eddig hiába kerestük ${ }^{1}$, úgy

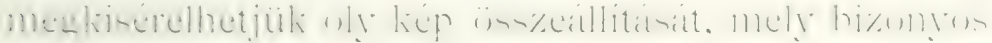
rés\%eiben föltevéses ugyan, mint bizonyos fokig föltevéses minden, a mi messze multakra ronatlozik. a melyneli hatalmas mesteroszlopa azonban az, hogy ¿t nemzet jelenére is támaszkodik, abból is meriti erösségeit.

\section{A HONFOGLALÁS.}

\section{A liép íme e\%:}

A között a néprándorlási maradéliokból šármazó szervezetlen, inkább gyülerés\% tömeg között, mely

Ez különösen a haliszatra és pisztoréletre vonatkozik, melynek igen sazdag anyaga szintén eryütt van, e mü leretébe azonban be nem reheti. 
Pannonia terein szétszórva élt, megjelent egy szám szerint nem nagy, de a korhoz képest kiválóan értelmes és szervezett néptörzs, a magyar, a melynek szerve\%ete. magatsahh s\%ellemi tulajdonságain kivüil, kiváló

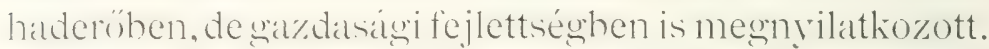
A haderó kiválóan lovas, a gazdasági szervezet kiváló módon nomiad allattenyésztó rolt, oly mértéliben, hogy. ezt sem a törzs asszonyaira, még kevésbbé kizárólag rabszolgákra bizni nem lehetett. Ezt a nagy érték és kivilt a tör\% śletérdeke nem engedte: és nem engedte a biztonság, mely népek és törzsek életében minden cselekvésnek igen hatalmas rúgója és irányítója. ${ }^{1}$

Feltehetö, hogy a mily mértékiben volt szervezete a magyarság haderejének, olyan volt a gazdasági szervezete is, melynek ellátásához szintén és nagyon kellett a Volf GYöRGY részéról feltett ,számbavehetö értelmi fejlettség".

\section{A TELEPEDÉS.}

A dolog természetében rejlik az, hogy a szervezetlen gyülevészség közepette megjelent szervezett. értehniles erös tïms hamall magrait alkotta meg annak a kristilyosodúsi menetnek, mely a grülerészéget a\% eróshöz és szervezethez való csatlakozásra bírta egyfelöl, másfelól annak az erósnek alkalmas részeit arra birta, hogy a gyüilevészség közé kiszállva, a terület megfeleló pontjain resse meg a lábát, vonzza maga felé és használja fel a szervezetlen elemeket: összeköttetésben maradván azonban a törzs zömével, hatalmi részével.

Tudjuk azt, hogy a magyar nemes középbirtokosság, az ország területén való eloszlásával, még nem

1 A pásztorkodó birtokos még a múlt század utolsó harmadában megrolt. 
is nagyon régen, söt napjainkigy is ezt a kepet tüntette fel.

Ennek ismét termés\%etes folyomanyal a\% crös önkuminy\%ati émék, a melynek ily višonyok között. a midön elöbb a tör\%s, mạjd a kis\%álló egres, majd «\% ivadéliaból leletkezö nemaetség ügryeit a fenforgó helyi viszonyok szerint önallóan intézni kellett, s\%ükséghépen kifejlödött. Es ebben rejlik csirája a királysionnak, majd a rendiségnek is, a mely at értelnileğ maguasabra fejlett szervezett magyart fölébe helyezte

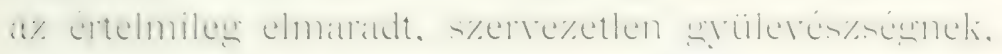
a nélküil, hogy a létérdek kölcsönössége az uralt és uraló közt megszakadhatott rolna; mert az egyik nem

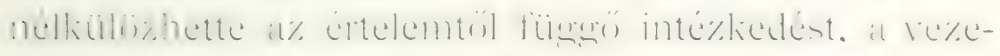
tést: a másik nem nélkülözhette a szellemileg alantasabbnak nyers munliaerejét.

\section{ÚR ÉS JOBBÁGY.}

Ebböl a viszonyból folyt az "lir" és a "jobbagy" riszonya, a mely, mint tudjuk. leghatalmasabban ott rolt kifejlödve, a hol a magyar birtokos dinaszta nemzetiségi területen vetette meg a lábát, nemzetségé-

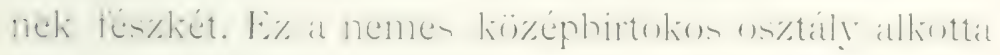
megr a politikai és nemzeti gerinczet és ebben rejlett egykoron az anthropologiának színmagyar anyaagál. De ez a hatalmas osztály sem maradt meg érintetlenuil. A\% érdekházasság, Mohács után sokszorosan a\% elfatjulás bizonyos neme is soliat változtatott rajta. Becses romjai azonban még megtalálhatók volnának.

Az anthropologiai arczképnek mai magyar anyaga

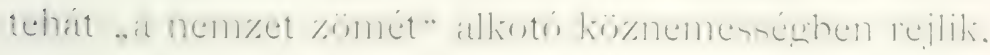
mely nemzeti önér\%eténél, de anyagi érdekeinél fográl es a tekintélyét is megóvandó, nem vasy alig vegyüilt

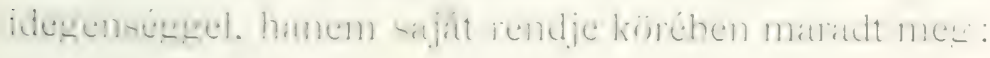


enneli maradrányait kell elsó sorban az anthropologiának felkutatni, meghatározni, a magyarság és a tudomány érdekében egyaránt.

\section{A HAD ÉS A GAZDASÁG.}

De már a természet rendje szerint is, az a szervezett, értelmileg magasabban álló faj sem állhatott csupa szemenszedett, egyforma erejü és szellemi képességü elemböl és a szervezet gazdasági része ‘is lényegesen másnemú volt, mint a hatalmi vagyis hadakozó, támadó, foglaló, hódító, védő részé; de színmagyar volt ez is.

A gazdasági szervezetból, melyet a megtelepedés

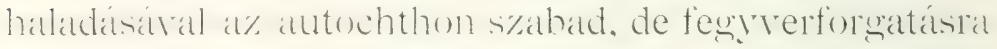
alkalmatlan rés\% öregbített: csupán ezekboól alakulhattak azok 'a magyar saabad elemek, a melyek annak az autochthon polgárságnak vetették meg alapjait, a mely különösen az östelepedés tájain az idegen elemekkel szemben, azt a bámulatos átalakítási és beolvasztási folyamatot teremtette meg, a mely nagy. irtó tiprások után ${ }^{1}$ az elnéptelenedett pontokon fel-

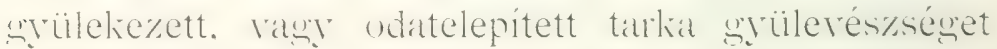
a maga magyar képére átváltoztatta; söt még anthropologiai jegyeiben is valósággal átgyúrta; a szem tekintetére nézve teljesen, legfoóképen azáltal, hogy a bizonytalan számazású, mohósággal ragadta meg az alkalmat és kedvezó áramlatot arra, hogy a nemzet fényes történelmi alapjára helyezkedve, mint annak ösi soron ivadéka tünjék fel. . .

Kelló történeti ismerettel, természetrajz-anthro-

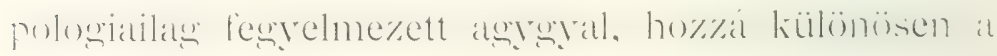
magyar társadalom - mint mondani szoktul -- 
intimele inambatinati ismeretével fels\%erelve, ant at hattalmats, alakito elemet - még manapsíg is - mentitililhatjuk.

A\%okitt a\% .. intimebb vonásokat", mint a\% ethikat jellemzíshe\% tartozókat, a kïnỵ befejezö rés\%ében majd meśtaliljuk. Itt még csak emnyi: a\% anthropologialiag lesbecsesebb magyar elemet ott kell keresnuink, at hol a\% ösi szerrezet, at törzs, at momzetse's. it sur. a hud keretei vagy nyomai még fölismerhetök. E\% a jövö nagy feladata.

Most atmegrïnk az igazi magrar tipusok méltittásího\%.

\section{A REGIEK MARADVAIYAI.}

A franczia .. Société d"histoire contemporaine" 1901. évi kiadrányában találhatók Mme REINHARD uti lerelei azokiól a benromásokról, a melyeket 1806-ban egy Magrarországon át Moldraországba urával tett utazás allialmálval szerzett. És 1806. június ‘-án kelt levelében leirja az Alföld magral népének öltözetét, hozzá hajviseletét is.

\section{RÉGI RUHÁZKODÁS.}

Azt mondja Mme Rer.rardo: „A lakosok igen nyomorultan ruházhodnak. Bó nadrágot viselnek durva vátsonból - e\% al magyar gatya - és kurtá, derékig. éró inget ugranebból a\% anyagból. E\% a két ruhatdarab zsirba vasy olajba van mártva s ezáltal vízhatlanná válik. Fölébe egy ki nem cser\%ett júhbörból ${ }^{ \pm}$ készült felöltöt - nyilván ködment - - kanyaríanak,

1 A kiszáradt bür megtïrésére hasznailt nagyon kezdetleges szerszimnt, eyellen darabot, KLIA Alrid barátom a mult század kilenczrenes éveiben mér megtalálta, $\mathrm{s}$ az ki is rolt 1s9fi-ban illitia. 
mely az évad - és időjárás - kivánalmainak meg-

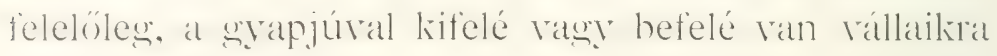
retve.

\section{RÉGI HAJVISELET.}

Rendesen fekete hajuk ${ }^{1}$ szintén az emlitett anyagba van mártva s összetanasztia lóg két oldalról arczuk köriil".

Mint tudjuk, a hajviseletnek nagy alakító hatása van az arcz kifejezésére is. REIxHARD asszony nem szól arról, hogy a haj be lett volna fonva és biztosra rehetö, hogy nem is volt; mert a hosszú haj az Alföld vénjeinél még a mult század - XIX. — második felében is gyakori volt, az elöre való omlástól pedign megórta a félholdalakra görbült és hátúl a haljba tüzoitt fésí. De az idöjárás minden riszontag̣ságának kitett pásztor nagyon kente a haját, ez a zsírtól összecsapzott és tényleg két oldalt lógott le a vállra. Talán az utolsó klasszikus alak, mely ReinHARD asszony leiráanak teljesen megfelelt, még a mult szazad ()-es éveinek elején, gondolom nemes Debreczen város hatalmas szarvú raczka kosait örizte a nagy Hortobágyon.

De a befonott haj is megvolt azért a színmagyarságnál; a kérdés az: milyen? A fül elött két oldalt lelógó fonadékot "varkocs"-nak nevezik, mi nyilván egy a tót "vrkwoč-csal és ez a hajviselet még ma is található lesz Zólyom megyében, hol tipikus tót arczú, korosabb fértiaknál, éppen Zillom városia hetivásárján 1898-ban még magam láttam, ennélfogra ez a forma tipikus tót, már azért is az, mert magyar elnevezése nincsen. 


\section{A CSIMBÓK.}

1\%, al mi tipilius maşyal és lievés esetben átjött a XX-dik szazadba is, a Somogyban, Iagy-bajom-

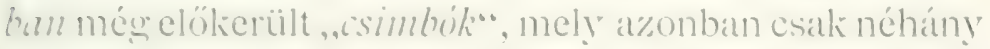
igren öreg - 79--\$1 éves - embernél maradt meg.

ime. elöttünk van a ,esimbók" hajviselet két somogyi ̈̈rege Zupor-L.ki Grörar és Áva-Loki JÁxos uramékmil, kiket lisbraver Amair 1901-ben lefotografozott

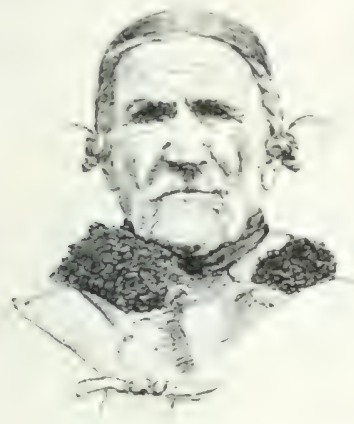

36. Zupor-Laki György 79 éves.

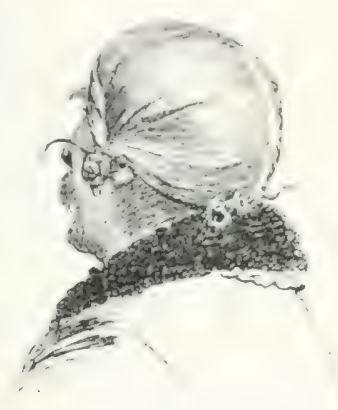

37. Arra-lóki János 80 éres.

Somogy-Nagy-Bajom.

és Koszkol Jexö barátom sürü hálózattal tollrajzra mesterileg áttett.

A ,csimbók“ fonását és kötését, egy eredeti, sajátos

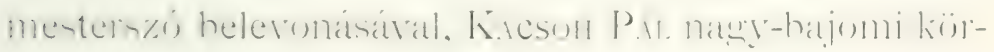
jegyzö így állapitotta meg:

„,A csimbók a férfi hosszúra növesztett hajának

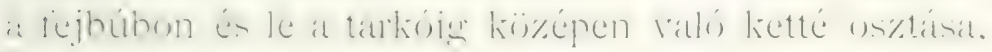
mind a két fül elött három ágra való fonása, és a fejet csinosítani való „csomós-bokrára" kötése“.

, ,Míg a férfi haja eléggé búsás és hosszú, a csimbók tisztán a természetes hajból telik; de mikor a hạj már gyérül és rövidül, akkor füzövel pótolják és errel kötik , „somís bokrára". ,A csimbókot mindig 
a fül elött kétoldalt kötötték, soha a fej kupajián

t. i. hátul egy csomóba“.

A csimbók kettös kötésú, ú. m. befonás után az elsö kötés a fonadék legvégén történik úgy, hogy csak az a kevés haj marad kötetlenül, a melyet hosszúsága miatt a három ágba befonni nem lehetett: a\% igry a fonadék régén megralliotott csomóval még egyszer kötik a csimbókot most már a csomó bokrára, 'a mikor csak a fonásból kimaradt haj marad kötetlenül és a csimbókból jobbra-balra úgy áll ki és hajlik oldalt és alá, a mint ezt Zupor LAKi Grörgr uram-

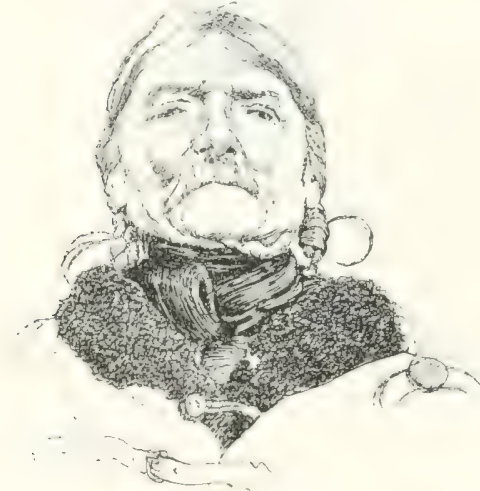

38. Öreg Mlajlát János 81 éves.

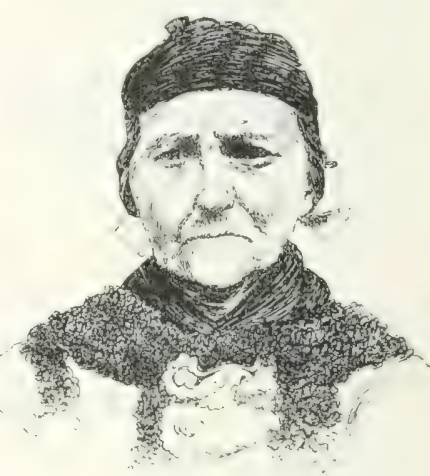

39. Najlát Jánosné

Böjtös Juliánna, 693 éves.

Somogy-Nagy-Bajom.

nál — 36. kép - látjuk. Hozzá kell tenni, a fona-

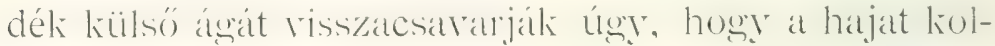

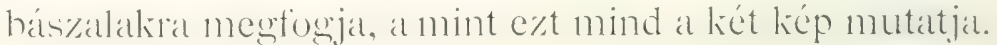

Be kell látnunk, hogy - egyelöre nem tekintre semmi mimikát és fiziognomikát — ez a régi somogyi

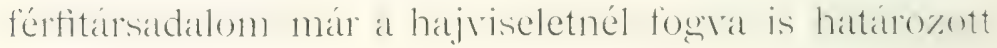
és sajátos jelleggel bírt - 1. 36., 37. és 38. kép; ugyanilyennel bírt az asszony is, melyet, kimélet daczára, a munka terhe korán megfosztott a\% üdeség- 


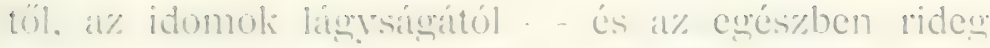
amezot még limorabbai tette .. al heliotés". at mint e\% it :iu-ik képen litható.

\section{AZ ÜSTÖK-FONAT.}

Bi\%tos hir és leirils s\%erint at Allöldön a mult starad elsö negredében még erg más üsi hajviselet is divott nagr liörben, mely abban állott. hogy a hosizúra nüresztett hajat, de csalk a\% üstökiön, öss\%e-

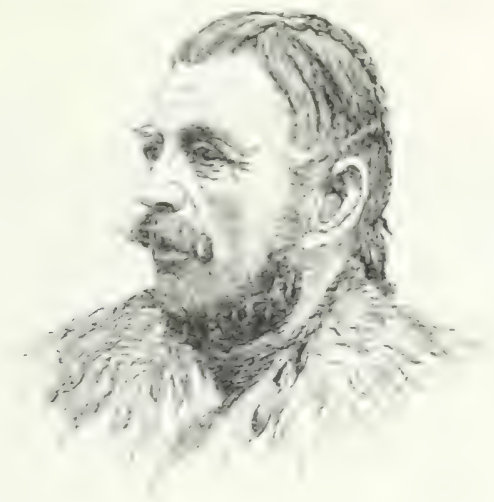

39. Al. Letünt haviselet.

fugrali. hárinasba befonták és a fonatot a fejbúbon ait hátracsaptál. Hátul a hosszú háj szabadon lógott. a mint ezt :39. A) képünk mutatja. ${ }^{1}$

KÖRSZAKÁLL.

Másnemü, mert szaliállas tipus a 'Tolnából való. liRg Jozsef uram, ki juhosgazda, tehát a juhászatot

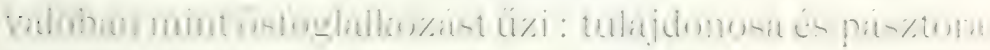
a nyádjak, bérli a legrelöket és nyája jöredeinéböl él. Hosszú hajviselete és hatalmas körszakálla túla-

1 Ez az adat Hijmezöjásárhelyen ïreg MACzELKA uramtól keriilt. l:i is iven is az apjanal litta, merg is mutatta, loogyan fogták öss\%e az üstrik hajat: ez utrobbi fogrist az én üstökömiön hajtottuk végre és iog rajzoltat I. Koszior. Jexö. E\% a hajrisclet tehát a XIX. szazad elején még élt. 

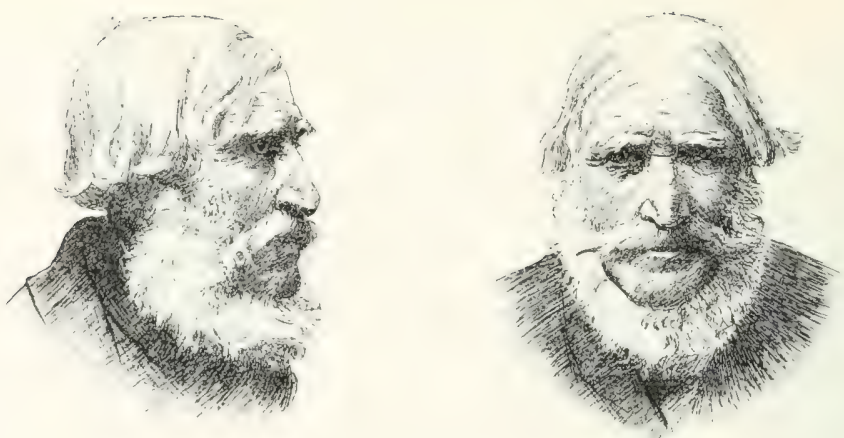

40. Varga Józscf, 73 éves, Uzsog-puszta, Tolna m.

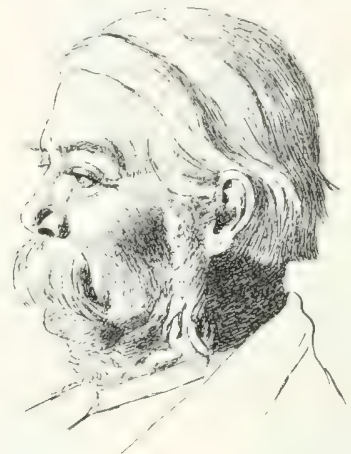

41. Széles József, 54 éves, Fáczánkert-puszta, Tolna m.

dunai viselet; megvolt Fejérmegye és a Göcsej színmagyar részében is; belepusztult az általános ,védóerö-kötelezettségbe."

Ugyanebbe a sorba tartozik Széles József uram, ki földnives és fiatalabb létére mégis megtartotta a régi hajviseletet. Ezek mind hatalmas, tiszteletreméltó alakok, kiknek s\%eméböl a hecsületesség, megbizhatosás, a józan itélótehetség szól a szemlélö felé : de s\%ól

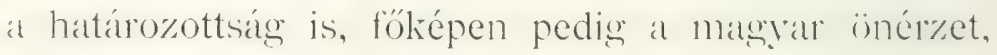
minden hivalkodás nélküil.

Eśgés\% megjelenésülkben, tištes mağuliviseletíhen. mely semmitól sem áll távolabban, mint az alázatoskodástól, de a bizalmatlanságtól is, minden arra vall, 
hury exclikel a\% emberelitiel komoly üsyben s\%obat lohet illani. s\%avuliban nyugodtan megr lehet bizni. KOSSUTH-SZAKÁLL.

Eppen úgr: mint à úri rendnél régebben, at polgiriag soriban is dirott és divik a . Kussuthšiliall"-forma. Ė nem eselély részben jürul ahho\%. howy a benyomás erronemuliségét megalliossáa. JÓZANSÁG.

Ezek a réribb szabású magrarok határozott nemes are\% nadsolikal, rends\%erint hatalmatsan fejlett bajus\%-

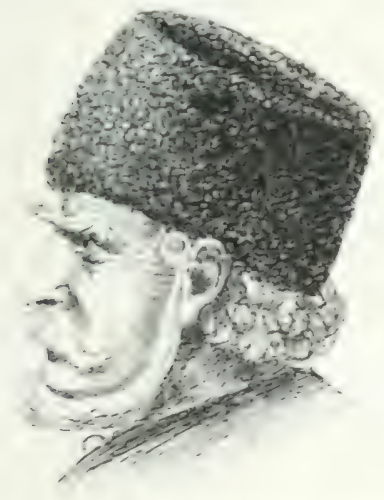

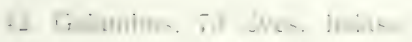

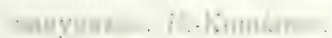

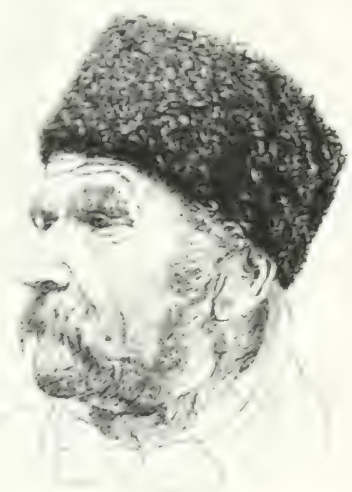

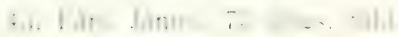

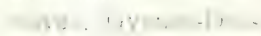

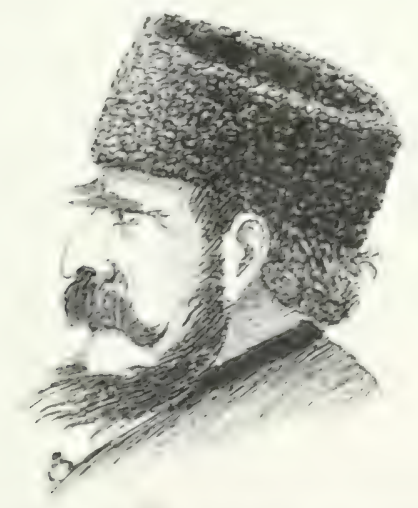




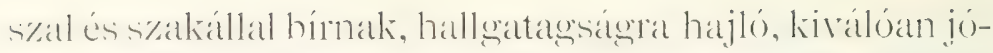
zann életü férfiak, kik között fölös šammal akad a\% olyan, a ki szeszes itallal és dohánynyal nem él, még pedig nemcsak takarékosságból, hanem tudatosan annak okából, mert hivatása nem türi a részegeskedést : „éberséget és

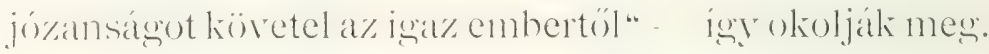

A halász nagygazdák és legénységük; a lovasgazdák, juhosok, a gulyás-gazdák, számadóik és bojtárságuk; a csikósok és kanászok mind ilyenek voltak.

A részegeskedés gyanuja, mely széles körben el volt és el van terjedve és a melyet különösen a nemzet ellenségei ennek kisehbitésére annyiszor felhasznaltak. éppen ez elemek jöannsíguhól kïretkezett. Küilönösen hangzik és mégis így van. A megfejtés az, hogy

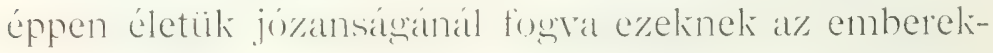
nek a kevés is megártott, ehhez pedig kizárólag akkor jutottak, a mikor ügyüik helységekbe, városokba szólította és nem kerüilhették ki ismeróseik társaságát. Így jutottak az alkalmi ivás következményei a nyilvánosság elé; és annál féktelenebbül nyilatkoztak meg, minél érintetlenebb volt az ivó idegrendszere. Evvel nem az van mondva, hogy iszákos ember nem akadt; kivétel elvégre mindenüitt van; de ezek az emberek

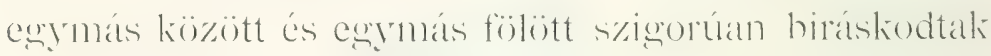
és tudtak rendet tartani.

Ily irányú, erkölcsileg fegyelmezett, pontosan végzett kemény munkával járó élet nevelte azokat az alak szerint hatalmas, arczkifejezés szerint komoly, nyilt, nyugodt és határozott tekintetü, tiszteletet pa-

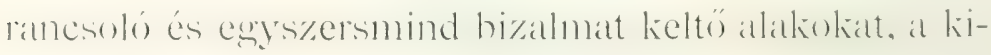
ket - fájdalom -... az újkor áramlatai, a melyek a magyar közrend legmagyarabb részébe is bekaptak. sorra eltuintetnek s nemsokára $k i$ is irtanak. 


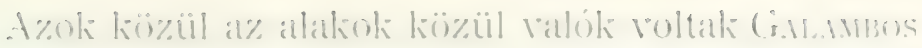

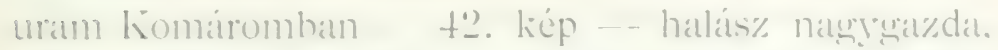

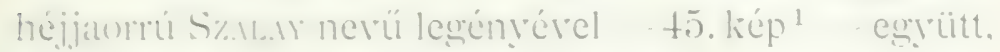
kik méz a viundorhalászatot üzték a Duna rérkomá-

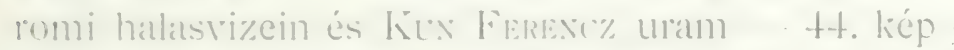

a Batlaton mellékén fekirö Kenessén. ki ... noha villis\%inüleg kún eredetü rolt . annyira magran viselte. kü̈ünösen a ballaton-Zala-res\%prémi tipust, kivált ๙aakill-, bajus\%viselete és hatalmas szemöldöke foly-

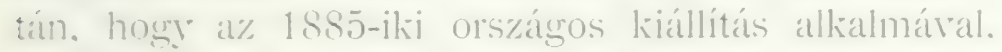
a mikor arczképét a halátsati kiállitás jeryzéle élén

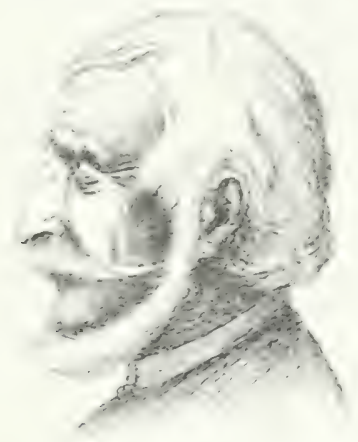

45. Szalay örer halászlegény, 72 éves. Komárom.

kiadtam, a balatonnelléki urak között a kiállitási irodában nagy vita keletkezett: mindegrik azt állította. hogy ezt à halászembert ismeri, a\% ö lözségéból való, esak a neve nem jut eszébe. Megjegyzem. hroș a kép nértelenüil állott a füizetben.

A mit aa régiek maradrányaji czímen eddig mesismertünk, arról kettót biztosan állithatunk: hogy ennek az elemnek igen hatálo\%ott és egynemú jellegre ioolt:

1. Ez volt a legtijlélutesebb és legigazibb "héjjaorr”, a mely kutatásain ¿ïzisen felötlött ; semita orrtril - 13. kép f. - vékonyuló és kihajló hegre silionbrizteti ner. 


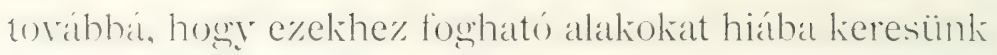
máshol Európában.

Ha a finneknél a kareliaiak oly szakállt viselnek is, mely a "Kossuth" kiorszakíllnak megfelel, a szem és a\% arw kifejezése egészen más: lágy, a magyaros nyugalmat, határozottráugot és önér\%etetet meröben nélliülözö.

Hogy magában az arcznak fiziognomiai összealkotásán, a szem tükre nélküil is kifejezést nyerhet a magyar sajátosság, ennek bizonyitéláa legren ( strok Avidás vak magyar ember, ki a borsodi Büikk-hegy-

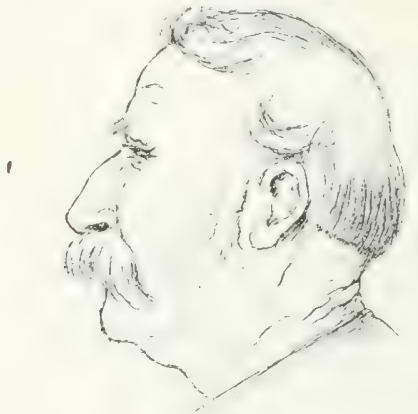

46. Csupor András, 63 ćres, rak. Noszraj, Borsod m.

ségben a noszvaji barlanglakó magyarok közül való és ritka tökéletességgel magán viseli a magyar arcz kifejezését, az atczélben is érényesüilö határozottrátúit. REINHARD ASSZONY.

Mielött az újkori elemekre mennénk át, térjünk vissza Rernhard asszony útleírásának ahhoz a részéhez, a mely az akkori - 1806 - magyarság jellemére vet világot.

A Rákos mezejéról írva, azt mondja ReINHARD asszony, hogy ott a régi magyarok egykori sátortábora helyén nyájak legelnek s a hajdan oly bátor nép mint nyáj terelteti magát. "Pedig a magyar liöz- 


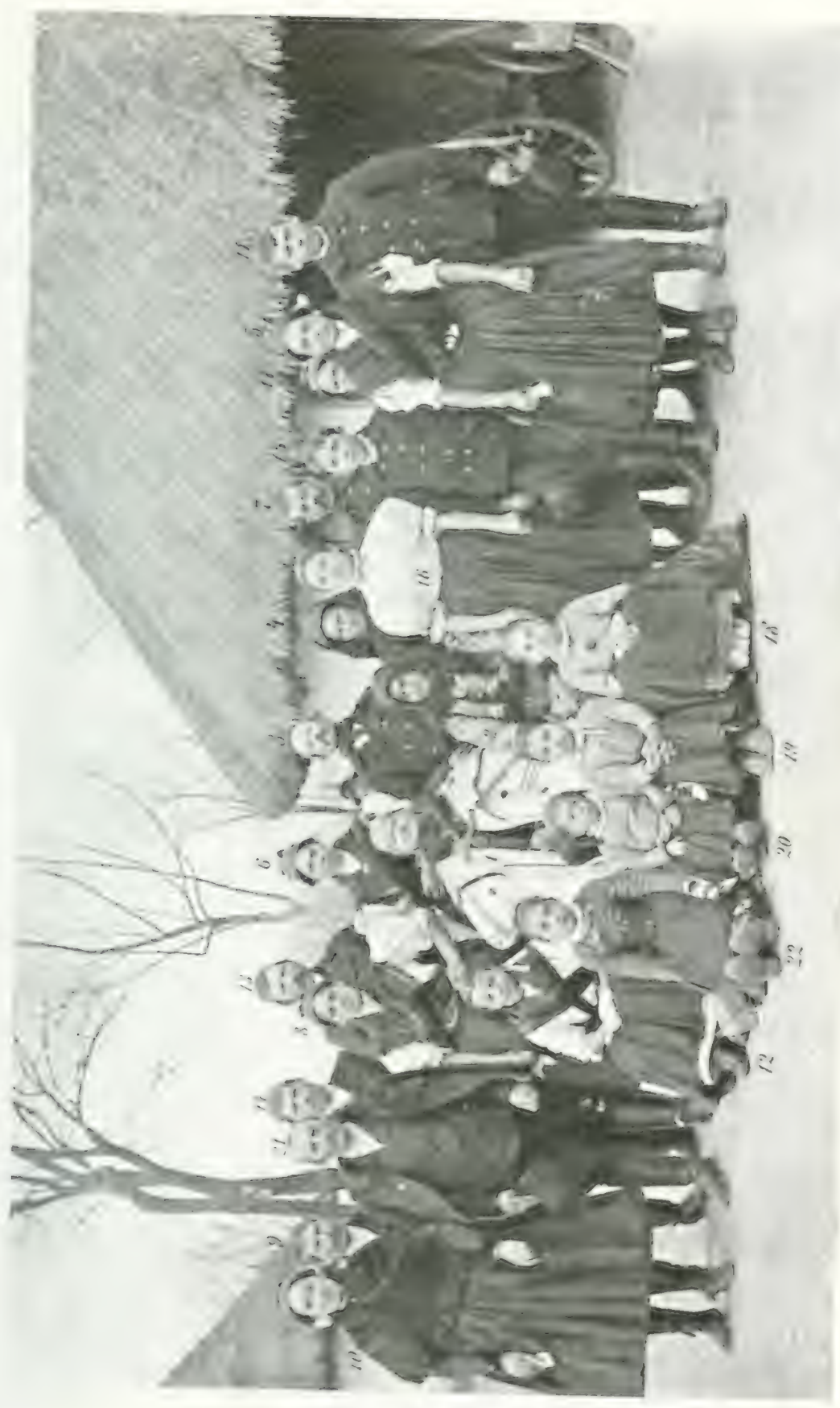




VI. T.́̇BL,A.

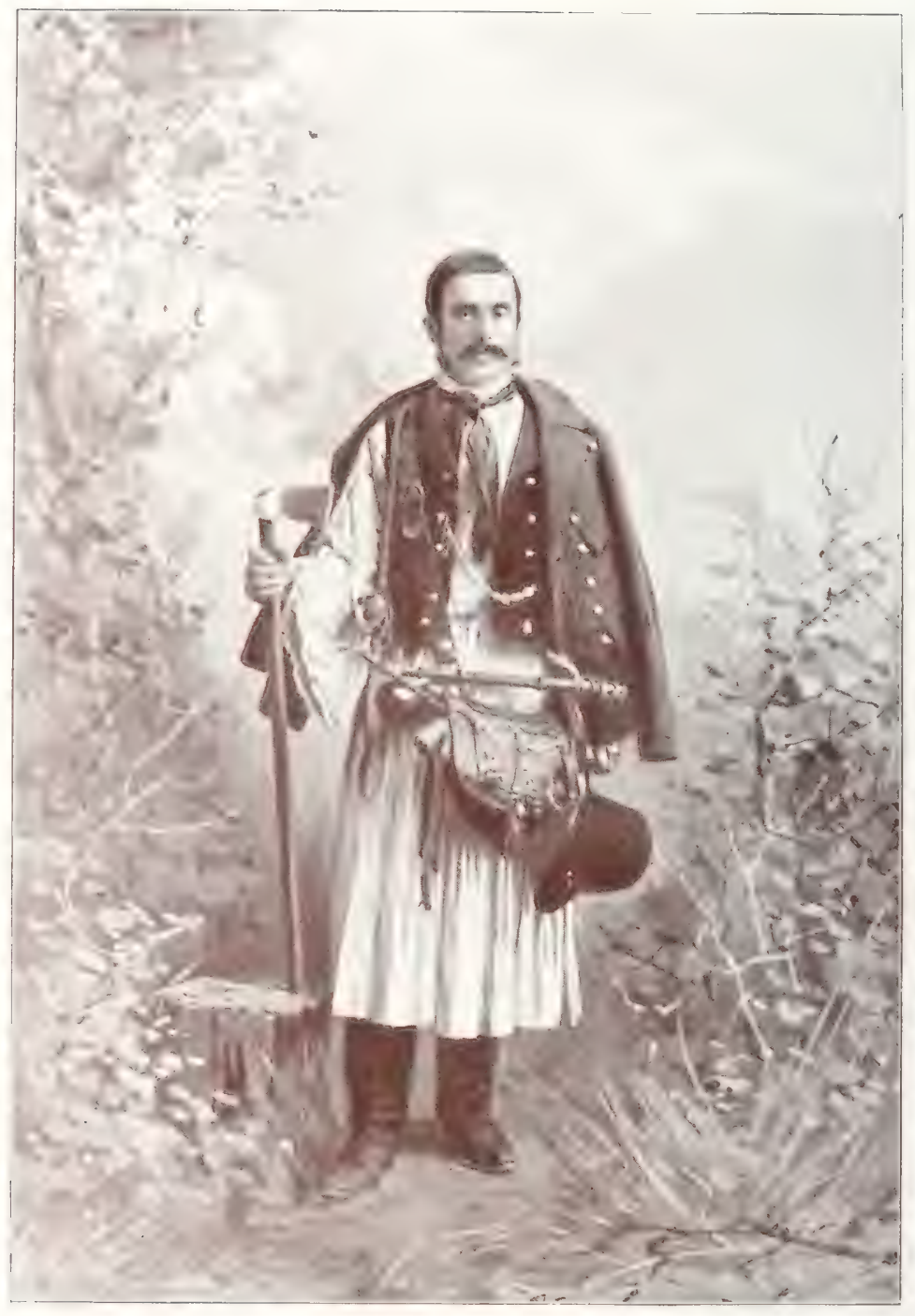

Kulemen János - Szrillös-Györk, Sonnogy. 
‥ I.1BI.A.

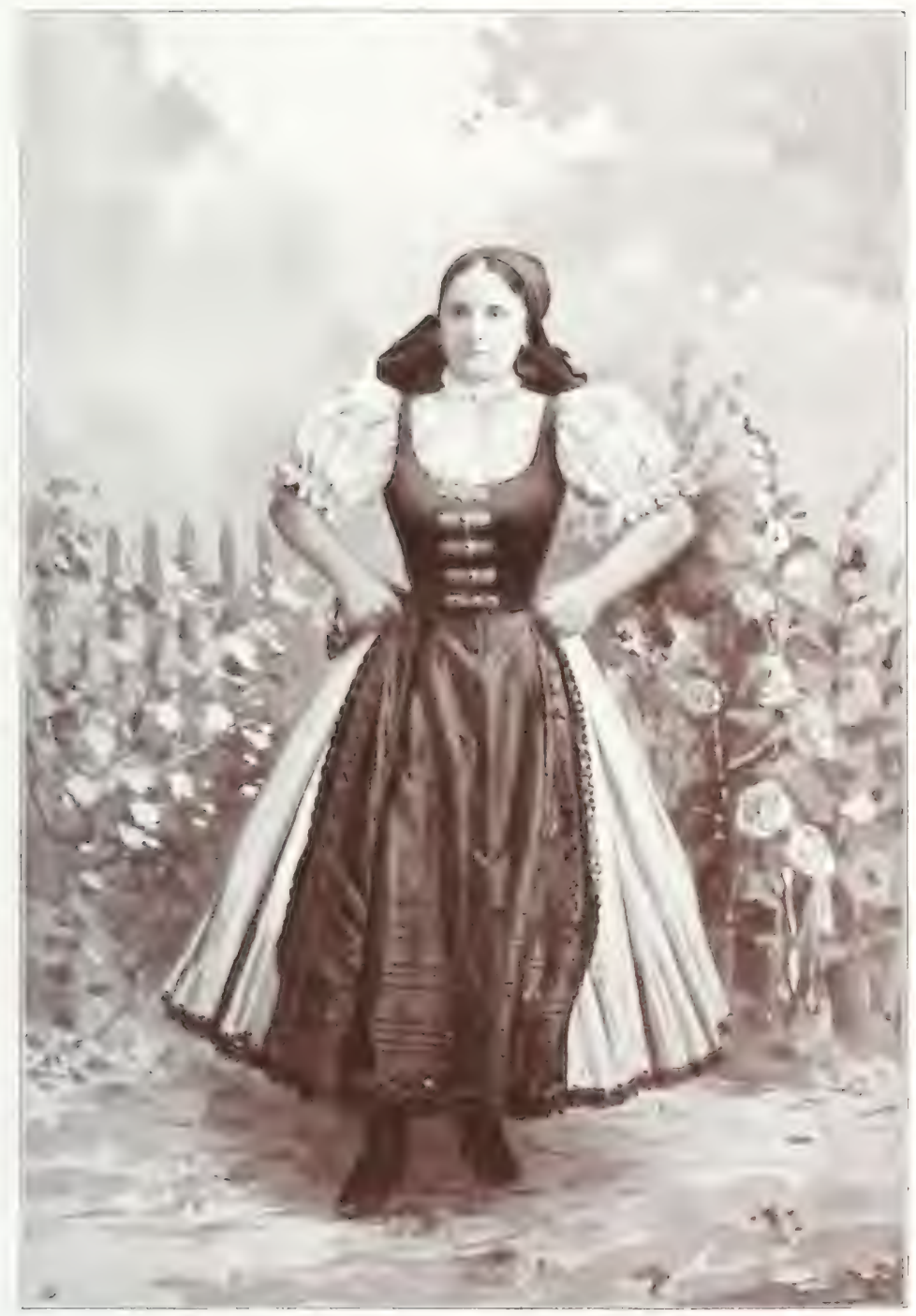

" i . . Vargar Anna - Somos $\because$ 



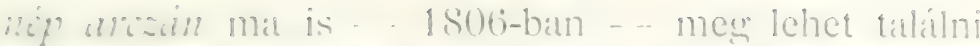

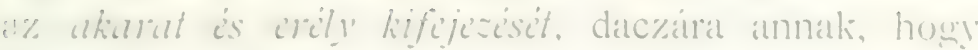

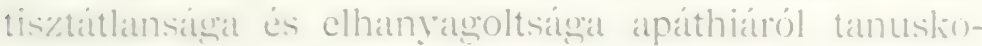
aik." (Kizsarolits volt annak a\% oka!)

... A\% Alföld sikján sok a nyáj, melyet a pás\%toroli tïes, kicsi lovakon öriznek. A . Bánsáğ lakossálgit

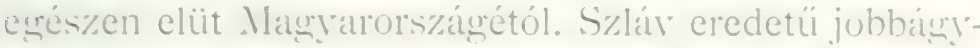
sidg. Ruhazata, tipusi, magaviselete semmiben sem hasonlit a magyarho\%. Most - 1806 hogy mind at liét fáj el van nyomvar. a masyar méssem. felejti. hosy. Attilitúl saimmazik s hogy mint hoditó rette birtokiba a arsadgot: bosszisan engedelmeskedik. mien a\% oláh szolgailag hunyás\%liodik meg. A magrat matratartasa biiszke óvistétel, a másiké alattomos meuFijlás".

Semmi kétsés. hogr fökép a magrarok szeme rolt a\%, a mely ezt a\% elforrulatlan, élesen figreli” astzonyt oly alaposan megoktatta és hálánk illeti meś ot halo poraban is, houg ext a leirast reánk hasptá.

\section{AZ ATTENET.}

A feladat immáu a\%, hogr elfogadható módon ait-

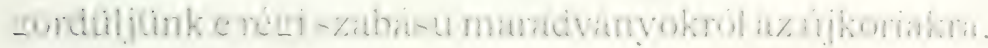
vagris teljesen napjaink magyarjaira.

Ez az átgördülés azonban esak akkor les\% becsessé.

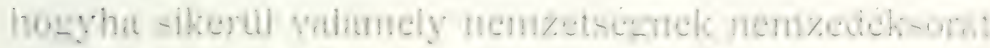
hö\%vetetlen, szerves. tehát vérszerinti errmásutánban hemutatni.

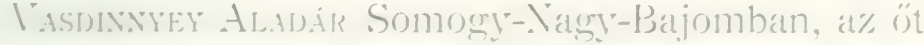
naşoron jellem\%ö aliarateróvel és ügyessérgel ezt a fel¿idatot fényesen megoldotta, a mint e\%t a\% l'-ik tábla

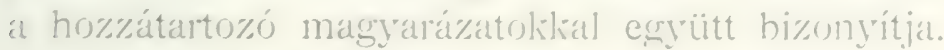


Ez a tábla egybefoglalja a \&1 éres törzsfötöl, Majlát Jaxos-tól kezdve - 1.38. kép is - ki, mint tudjuk, még a csimbókosokhoz tartozik, le az 5 éves

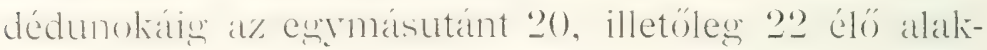
ban. Ez a sereg, bár két anyától eredve, mind egy és ugyanazt a törzsfö́t, Majlát Janos-t uralja.

Ennek az eleven csoportnak fölvétele nemcsak azért nevezetes, mert amateur hajtotta végre, hanem kiilinoisen àért, nert ily csoportnak ráhes\%élése egrike a legfáradságosabb és legkényesebb feladatoknak.

Vessünk egy pillantást az V-ik tábla csoportjára. Eigés\% altalanosiaghan kimondhatjuls, hogy nohat teljesen a közrenddel van is dolgunk, az arczok szépek. öntudatosak és értelmesek - végig a kis gyermekekig.

A riseletre nézre az asszonynépség a konzervativebb elem, a mint ezt az \'-dik táblán az 5., 6., 8., 10. számú menyecskék bekötése bizonyítja. A férfi teljesen átalakult ruhára és hajviseletre nézve: az elóbbinél csak a csizma maradt meg, de már nem az ósi, hegyesorrú forditott saru, hanem a „rámás", az utóhbinál at rédöero-kötelezettién elsöpörte a rési csimbókot; az emberek megérezték a rövid haj nagy elönyét, mely a gyors fésülködést teszi lehetóvé és megérezték a rörid haj higienikus hatásit is. Hogrothat azonban a férfiak bámelyikével azt a „crucis experimentumot" régezzük, a melyet I)kik és Dr.RB hajzatíval hajtottunk végre, elóttünk áll még a csimbókos nemzedék egész sajátosságával.

De a sorozat és a törzstábla másról is megoktat. t. i. arról, hogy már itt is belevegyül az idegen vér - német Beck, 6., 11., 12., V. tábla - a nélkül, hogy a tipusra már érezhetö átalakító hatással volna. 


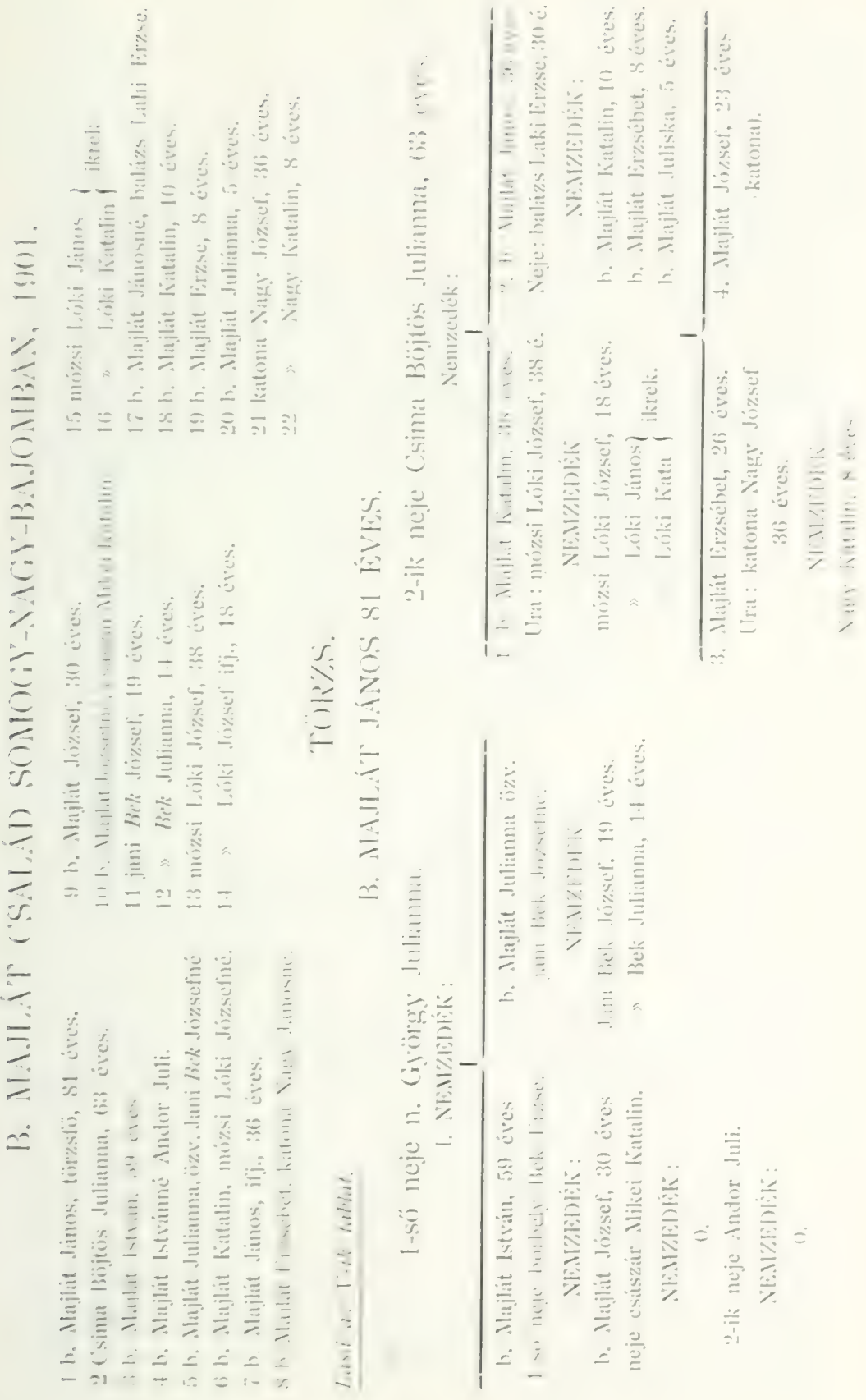


Hogy a Somogy anthropologiai tetözését is megismerhesiül, erre szolgál a V'l-dik tábla, mely Kelenex

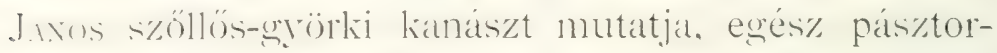
felčerelésével együt, mint kandiszbalta, at somogyi forma, mely a rézkorban birja alakszerinti "usét s mely nem szerszám, hanem fegyver; a „nehézustor“, újabban karikás, az ékes, sallangós tarisznya, melyet PATKó, a híres betyár ,kreált" és a mely teljesen kiszorította az ösi vászontarisznyát; rajta a kabak. A lobogós ingujj és a sürún korczolt, ránczos, bő gatya, semmit sem ron le a legrény magraros délczerségébúl. areza nvilt, tekintete éppen ilyen, szól belöle büszkeség, önérzet és tisztességtudás egyaránt. Ezekröl mondja a népdal:

\section{Megismerni a kanászt \\ Éles járásáról, \\ Tánczratermett lábáról. \\ Tarisznyaszijáró1.}

A Zseliczség ugarain annyi volt a pásztorok között at hasonló megjelenésú alak, hogy mind bevált volna „tipusnak". Ha ezt az arczot jól összehasonlítjuk a Zupor Laki György uraméval - 36. kép, - lehetetlen a tipus azonosságát föl nem ismernünk, noha a korkülönbség igen nagy.

Azt a tartást, mely ennek a somogyi kanásznak alakjából sugárzik, azt az önérzetet, a melyet arcza föltüntet s mely abból a hüs\%ke tudatbúl fakad, hogy ö magyar, ennek mását hiába keressük más népeknél és pásztoraiknál, vagyis azoknál, a kik még ösfoglalkozást űznek.

A VIl-dik tábla a somogyi menyecske tipusát mutatja. Önérzetes, nyilt tekintetü, üde és délczeg tartású teremtés, mely úgy, a mint térül-fordul, a mint 
esipöi farasközben megrengenek, eleven képe annak. a mit ..tüzröl pattant” és ,kaczkiás" menyeeske alatt ertünk. a minek pairját hiába keresnöl a\% egés\% világ kï\%népénél. E\% is ér\%i maģarscigat, bátran s\%óba all barmely magaasrangúval; šó dolgában pedign nem malriad adósia senki fiának. De ezekre illik a táne\%s\% is. mely mondja:

Friss münyecste kuruc\% Örzsi.

Embër lïgrön li megrior

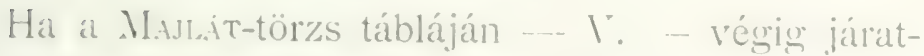
juk szemünket a\% apró és serdülö leánykálion, mindenünnen reánk néz a ,kaczkiás menyecske" gyermekliori liepe.

NÖI SZÉPSÉG.

Eirdekes és tanulságros, hogy a székelység tánczszal‘aiból nemcsak a lelkület sajátossága szól felénh. hanem kivehetjük a magyar nöi szépség fogalmát is. a mint a nép lelkében él: de e mellett kiválik a\% egréni izlés is, mert a bör és hajzat alapszine nem egrnenü., mint a fajnépelnél. A diagnózis ím ez:

Se nem kicsi, se nem nagl,

Éppen hozzám való vagy:

Igenyes vagy, mint a nád,

Hozzám szabott az apád.

Tehát temet szerint közepes, sugál növésü, hajlékony legı̀en. mint a nádszál.

Ez at leány soliat ér,

Sem ösztörér, sem körúr.

Sem fekete, sem fehér.

Tehat arányos idomai legyenek; a bör és hajzat szinére nézre itt áll a magyar šálló igge diagnózisa: ., se nem szölie, se nem barna, az igazi magrar fajta." 
Akámilyen szenes tơke,

Szebb a barna, mint a szöke.

Van szeretöm, szóke leány,

Nem piros, nem halovány.

Ellentét az ízlésben. A szőkeséget jellemző rózsás arczszín ügyes kiemelésével:

A szeretóm arany âma,

Se nem szóke, se nem barna.

Izlés. Valószinúleg a vörösesbe játszó szőlieséret érti.

\section{A HERVADÁS.}

De az üdeség és délczegség ezeknél a nôknél nem mindig a kor természetes törvénye szerint hanyatlik el; legtöbbször korán muló. A közrendú magyar asszonyon igen nagy a teher. A család, a háztartás és küiönösen a nehéz mezei munkában való részvétel hamar leszedi az arez hamvát: az alak kemény formákat ölt, az arcz kiránczosodik és az aggkorban legtöbbje olyanná válik, mint a MAJLáTtörzs nagyasszonya — 39-dik kép.

De a kivétel sem ritka. Rendesen a némi hízásra hajló nöknek, még magasabb korban is, kellemes a megjelenésök.

A régi szabásból a mostaniba átgördülvén, lássuk immár napjaink magyarjait tüzetesebben is.

\section{IAPJAINK MAGYARJAI.}

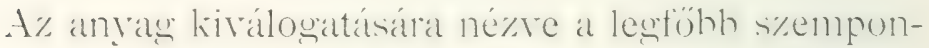
tok, a\%olinak rilágúnál. a miket a kongressusi kitdrány méltatasihan es biralatahan megtudtunk, a kiovetlezok:

1. Föltétlenül kerüini kell azokat, kiknek neve más nemzetiséme mutat : ilyenek: Német. Trit. Horvit. 
Leneyel, Syâs, Rác\%, (seh, Talian, Oros\%, Olah, Bolsair, szerb, Bos\%nyak stb. Ezeliet a\%onban geneatfogikus tamulmányokial kapesolatban, a magyar be-

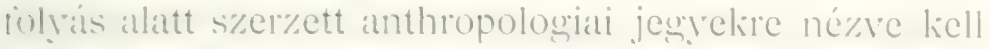
majadan tanulmany támórivái temni.

2. A tanulmányozáts hasonló rendjébe tartoznati mindazok is, al kilinek egróltalában idegen nyelvä neriik van. noha mál magyaros benyomásúak.

3. Mindazok, a kiknek vezetékneve helyséset, terüiletet és hasonlót jelent, erre való telintettel ott tálgăalandók, a hová a nér mutat, vágyis: a ,Cisanadit” nem lehet Heres megrye elemei közé vonni és tályalni, al "Hevesit" nem esanádiaklial együtt renni: "..Komáromit" nem lehet somogriakkal méltatni: a ..Somogyi" nevǘt komáromiakkal. E\% nem a magyarság alaphérdésére, hanem azokra a finomabb meg-

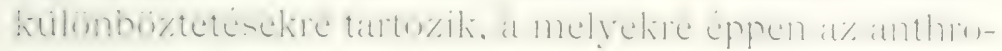
pologiának is törekednic kell.

\section{RÉV-KOMÁROM.}

A magyar arczra és tekintetre nézve a próbakövet ott találjuk meg legbiztosabban, a hol a viszonyol úgy alakulnak, mint például Rértiomáromban, a hol ¿ változó, áramló, könnyen engedó városi elemekliel s\%emben tömör elem áll fenn, mely hajlam és hivatás szerint egrnemü, nem vegrüil és csak kevés töredéke reszi fel a "divat mázát".

Ezt a\% elemet ott a\% u. n. ,s\%ekeresgazdák" alkotják megr; nem furarosok ezek, hanem erös polgálrok és birtokosok. Ezeknek sorából valók a V'lll-dik táblıt arczképei, a melyek a Sebestyének, Móroczok és PatiVagyok közül kerültek ki; nem válogatva, hanem úğ,

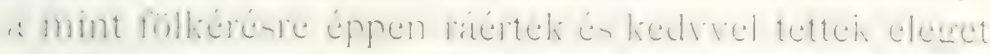
a fölhivásnak. A ki a révkomáromi szekeresgazdák 


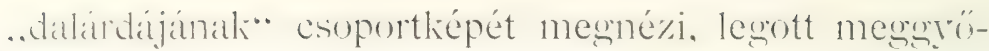
zödik, hogy a VIII. tábla valóban ,tir 'sokat"“ ábrázol. És ha ezeknek fejére forgós méby a sisakot vagy kósagos, nyusztos kucsmat teszinnk, elöttünk rannali

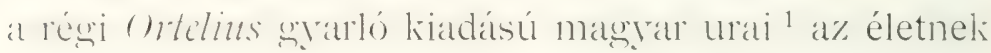
és igazságnak megfeleló alakban. Még azokban az Ortelius-képekben sem birta a kor - XVII-dik század - gyarló múvészete a magyar szem határozott, önérzetes tekintetét eltüntetni.

A VIII-dik tábla férfiai egyféle határozott tudattal ültek a készülék elé s e tudat az, hogy én az igazi magyarokat keresem, ök pedig azok.

Megfelelö renden, bármely más nemzetnél, ehhez fowhato tekintetet s egráltalában arczkifejezést hiáha lieresünk és önkénytelenüil is feltolul a gondolat azolira a döntó tulajdonságokra, a melyeket VáMBér mint a magyarság államalkotó és államfentartó nemes és Kiváló tulajdonságait felállított és kimutatott.

\section{HORTOBÁGY.}

Szakasztottan ugyanez a kifejezés üil a hortobágyi számadó gulyás arczán, IX-dik tábla, avval az egy kïlinbséggel, hogy s\%erzett fiziognomiali jegre van. All pedig ez a szem-nek bizonyos hunyorító kifejezésében, mely a szempillák izomzatának — S. kép C. D. - és a szem körizmának - u. o. B. E. és kis mértékben a járomizmok - u. o. F. és I. -

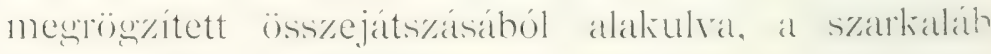
ránczozatot is kifejleszti.

E fiziognomiat jey kelethezéséneh ohal pedign a lewelóterület sik voltából és a szimmado felatatahól folyik. A számadónak messze távolban is .szemmel kell

1 . Ortelius redivivus et continuatus, oder der ungarischen kriegsEmpörungen historische Beschreibung" etc. Frankfurt a/M. 1665. 


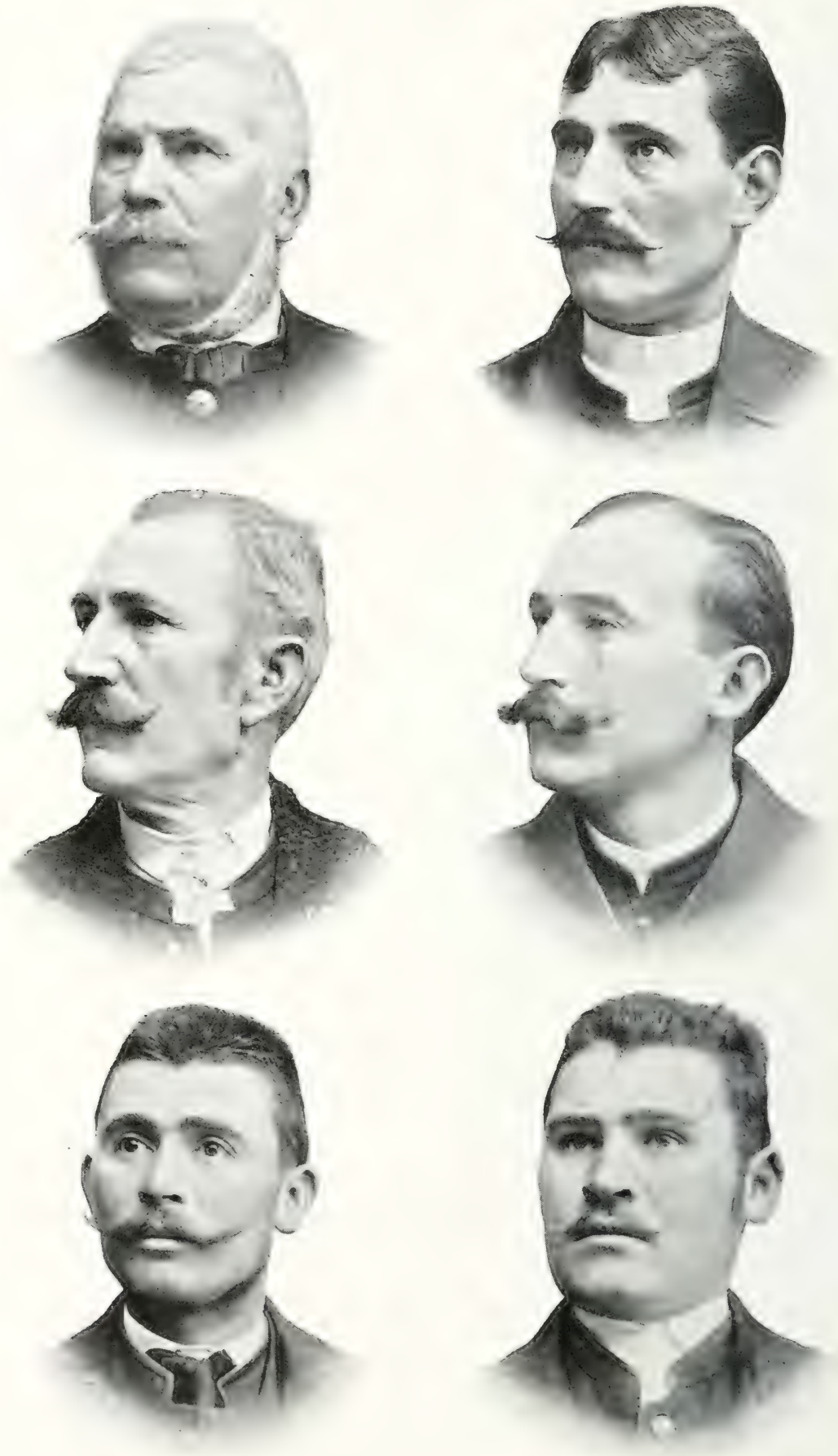

1ג. Sebestyén József, 62 éves - apa; Sebestyén Sándor, 51 éves - öcs. Ifj. Sebestyén József, 29 éves - fiú. Mórocz Lajos, 25 éves. Pati-Nagy P’íl, 26 ćves. Pati-Nagy Sándor, 25 éres. 
18.2813

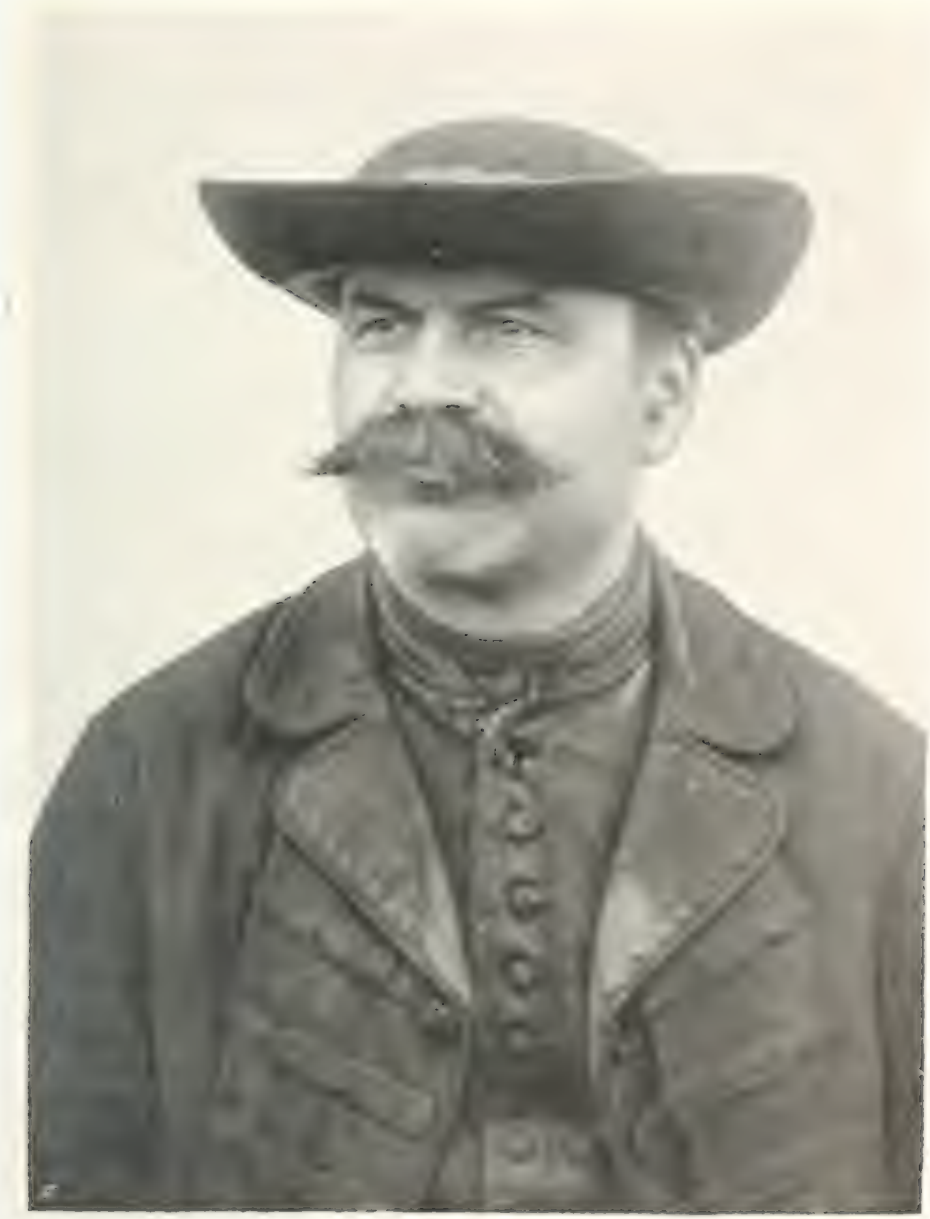

Hiin. ill

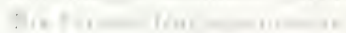



$\because \%(1+$
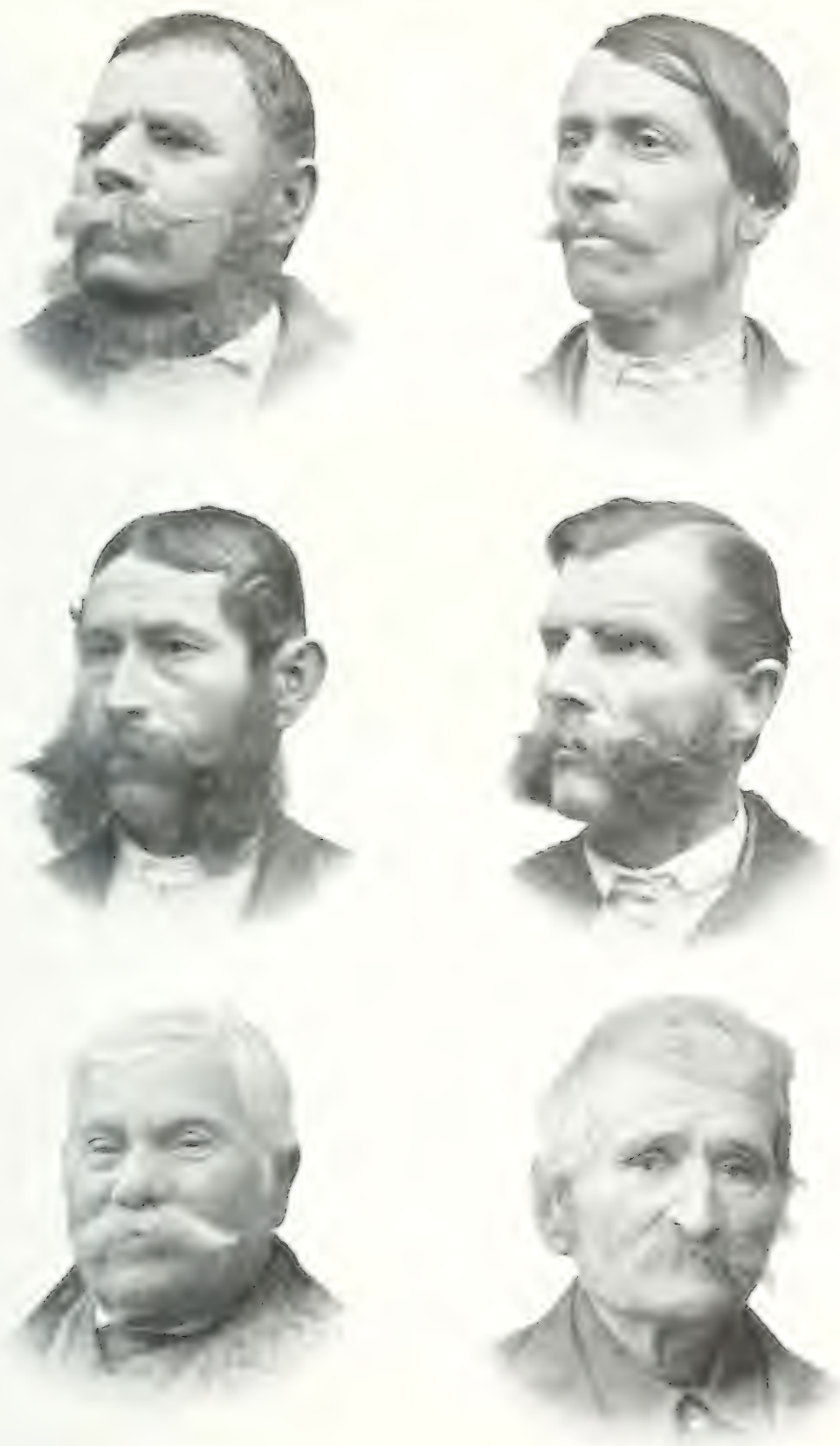

Szenter János, 48 cíces Cs.-Tomaj. Betyár Györor, 42 éves - Gy.-I)iós. Orem Dobí - Szequ?.

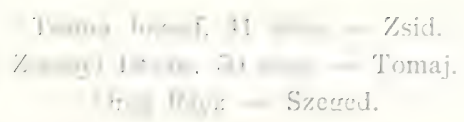





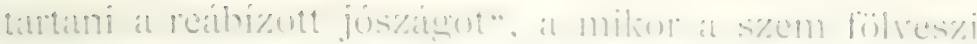

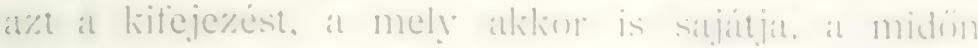

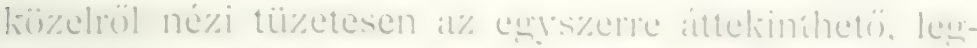

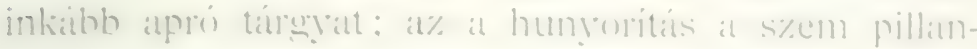

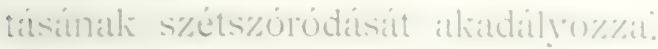

\section{B.ALATONMELLÉK.}

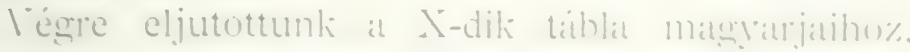

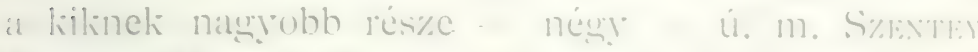

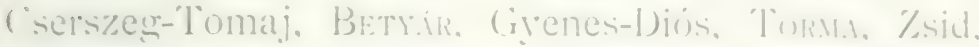
ZEREXI. 'Tonnaj, tehat mind Balaton-melléti ember. Šakill és hajriselet szerint mind a néry mais-mais:

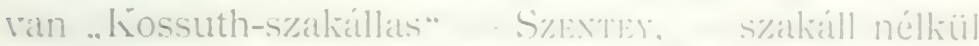
valo. vékony bajuszú "Tomm., - és két .becirlice..

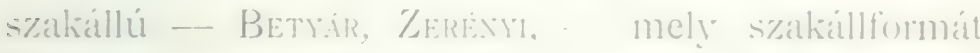
Sumogr nen egr ridékén elfogudta a nép a\% elnyo-

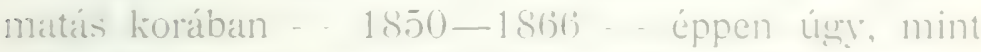
elfowadtak rolt a régiek kïzüil azok. al kik a ..flanczia hiboruban” rés\%t rettek. azt at s\%aliállriseletet. a milior at barkószakáll egrbevágott a bajus\%s\%al. a\% are\% alsi) fele azonban ..puczérra" volt borotválváa.

A\% egészen parasztos "Tormit és a máll .uras".

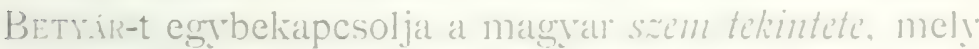
nyususodt, határo\%ott, önér\%etes. Mind komoly. erös ember. ú. n. ..rinczellér..., ki saját szölöjét sajját ke\%ével míveli s è után él.

\section{SZEGED.}

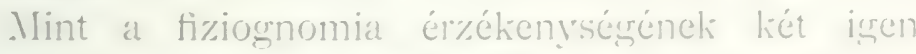

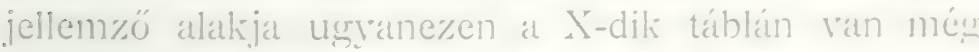

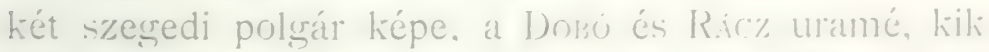

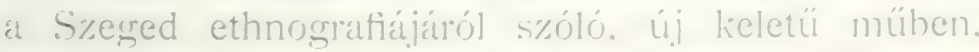
mint a felsö- és alsóváros tipusai rannali adva. Semmon

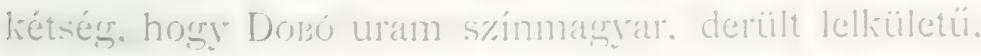

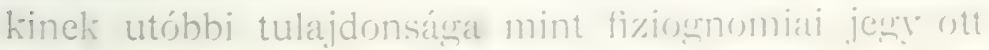


van a szeme tájékán. Egészen más Rácz uram, ki nyilván a törökilág után s\%egedet mestzalló elemek ma már teljesen meg- és át- meg átmagyarosodott ivadéka, kinek már éppen csak a ,szeme csillogásában" van valami cseppség, mely korlátozza a teljes határozottság kifejezését.

\section{A TANÚSÁG.}

Ha valani, úgy az a föltevés áll legtávolabb tölem, hogy ezekkel a ,magyar arcz" kérdését meg-

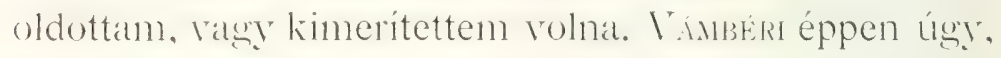
mint Hunfadry s velök iskoláik megegyeznek abban, hogy a magrarsag bárhol alakult legyen, regyes elemek šerencsés keveréke; és minthogy a\%: a legrégibh alkotó részek is atavisztikus soron foöl-fölvetödnek a nemzedékekben. Ezeknek fölismerése nagy feladat, mely esak atgrondolt, szigorúan régrehajtott módszerrel les\% lehetséges, a melynek kifejtése azonban inkáhh a magyarság jellemrajzának keretébe tartozik.

Abban azonban meg vagyok nyugodva, ú. m:

1. Hogy sikerült az anthropologiai arczképek fölvételére tartozó föltételeket megállapitani.

2. Hogy kimutattam a szem kifejezésében a magyar jegyet, mely az egész tipus lényét kisugározza.

Hozzáteszem, hogy ez a jegy azoknál is kifejlödik, a kik idegenül beszármazva, ráhelyezkedtek a nemzetnek a köztudatban éló történelmi alapjára, avval az egy különbséggel, hogy ezeknél bizonyos indulatok másképen, rendesen hevesebben, kitörésszerüen nyilatkoznak meg akkor, a mikor az ösi soron szinmagyarnak vehetö elem csak fölmelegszik; - - és hogy amazoknál a kitöró harag, a féktelen düh oká 


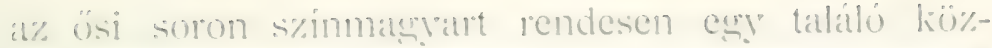
mondistal vame mély értelmü humoros s\%ora birjal a

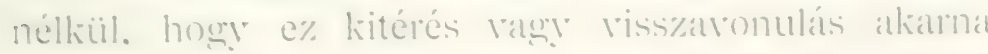
lenाาi.

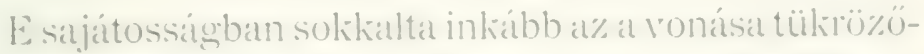

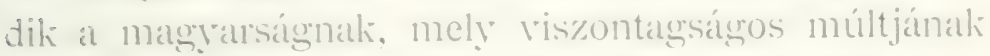
sok. ig̣en nehéz helyzetéböl kiseugitette, s lehetöré tette. hous mint csekélyebb szám a tömesgek eröszaliálval szemben is uralkodó faj maladhasson, intéznényeit. s\%oliásat megörizhesse és az ideğenségre ráruhát\%hilsicit.

\section{FÖJEGY.}

Ha most mál úgy állitjuk föl al kérdést: a s\%om?

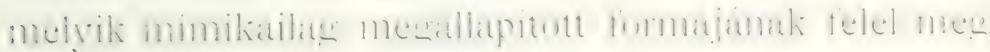
¿ magyar saem? legott elöttünk terem at, a mit M.NTEGAzzA kifejtett és rajzban is adott, a mit a\%

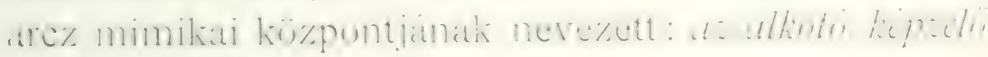
cröt kifejezö szem - 6. kép.

Es valóban, hogy ha a ,napjaink magyarjai" szathaszban a VIII-ik táblára vetjük tekintetủnket, ez a s\%entorma egészen tisztán és félreismerhetetlenuil

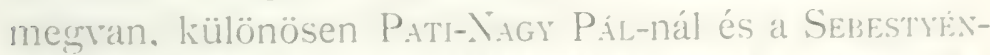

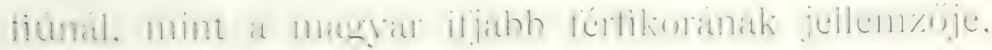
¿ mely még éppen oly távol all a kiábrándulástól. mint a\% aggghol bölcseségétöl.

Es kiválóan e\% a s\%emforma a\%, a melyból legstöbbs\%ör kisugár\%ik a\% a sajátos indulat is, mely föl-

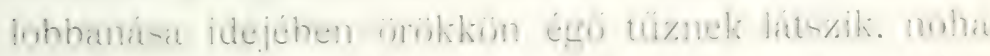

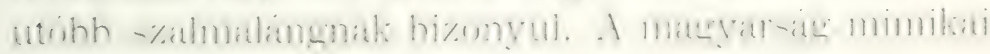
és fiziognomiai jellemzésében tehát egyetlen pontrá sérünk, mely hasonló MANTEGizza Piolo meghátálozásáho\%, hošr t. i. a siájczi embert isak nyilt tekintele jellenl $\approx i$ - 1. p. 2s. 
De azért mégis lehetséges a magyar arcznak bizonyos másnemü. altalánosabh értékü meghatározását is adni.

Az ú. n. komplexióra vonatkozólag, a népszájon

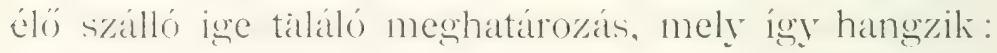
,Se nem szöke, se nem barna az igazi magyar fajta“. Oly forrás, melyet nemcsak a szerzó tekintélye, hanem eljááának kritikai volta tesz kiválóan bessessé, ${ }^{1}$ a hontoglató magyarigrol anthropologiai értelemben azt mondja: ,Általában véve kicsi, bama emberek voltak. . A $\mathrm{A} z$ bizonyos, hogy szerfölött nehéz e jellemzés fokát és értéliét pontosan meghatározni.

\section{A TÖBBI JEGY.}

A magyar arcznak ninesenek kirívó faji jegyei, ¿ minö a tót arcz kiálló pofacsontja, ázsiai fajoknál a ferdemetszésü szem, az ellapuló òr, stb. Egyáltalában a magyar közrend férfiainak arcza nagy átlagban megrelel a fértiszépség európai fogalmának: kifejezéséböl hiányzik a lásyán, annál erósebben nyilatkozik meg a határozottság és az önérzetesség. Az orr sokszor igen nemes formájú; átlagosan fejlett. A hajzat és szörözet átlagosan véve erös fejlödésü.

Mint atavisztikus jelenségek azokból a foobb részekböl, a melyekból a magyar atakult, elöfordul ritkán a\% erös pofacsont, a mesize szétállo szem és a röridebh. érezhetöen pis\%e orr. Ezek az atavisztikus jelenségrek okai annak, hogy idegen kutatók oly rokonságokra is hivatkoznak, a melyeknek bizonyítása lehetetlen, s a melyeknek alapja a puszta látszat.

1 PAUler Gyula: „A magyar nemzet története az árpádhizi kirälyok alatt." II. kiadús. Budapest, 1899. I. p. 3. 
II.

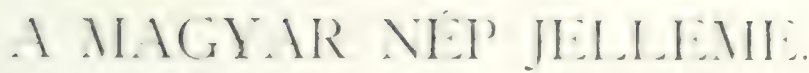





\section{A KIIETTES}

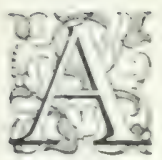

magrar nép jellemét meghhatarozni és megrinni szép és igen fontos feladat, mert a jellem meghatálozásán át világossá kell válnia soli

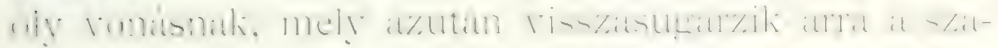

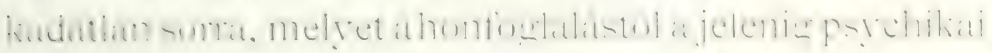
és ethikiti alapolion megalkothatunk.

De a föladat s\%erfölött nehéz. Elözményei, kivált a régibb korra ronatkozók, irodalomban és múvészetben alig akadnak. Az összehasonlitásra alkalmas rokonanvag csak töredékekben kinálkozik.

Megjegyzem, hogy mindez arral a hözrendre vonatkozik. mely a magrarság zömét alkotta, s a melynek

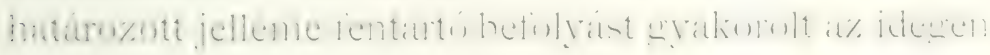
hatásnak leginkább kitett rezetö elemre is, mely természetszerüien a zömre támaszkodott, ennek tartalmából merítette saját erejét.

A képzömürészet, küiönösen régribb ronatkozílsokban, semmit sem hagyott reánk olyat, miböl a maşıar közrend bensöbb életére köretkeztethetnénk.

At jelen képzömürészete a\% ú. n. "festöi" hatásolira törekszil és jobbadán azon van, hogy e czimen a toprongrost és a duhajkodó, czifra alkoholikusit állítsa szemünk elé: a magrål nép jellemzésére pedic egrik sem igaz.

A legnemzetibb iróink múreit , dišitơ" illus\%trát- 
cziók legtöbbje, akár az arczot, akár az alakot nézzüik, akál azt, a mit Gratiolet nyomán a testmozdulat symbolikájának nevezünk, csak ruházat és a helyszin szerint valahogy magyarok.

Az a magyar festó, a ki szeretettel, odaadással alapos tanulmány tárgyává választotta volna a matgyar népet és intim vonásiahan törekedett volnat e népet és lényét megjelenés és cselekvés szerint sorozatosan elénik állítani, az még nem jelentkezett.

Az irodalommal sem állunk sokkal különben. Résibb vonatkozású, a zömhe benyomuló, tudományos értékü — ha teljes megbizhatóságot kérünk — nem akad. Az újabb keletú, minden „összehasonlitó" módszer daczára felszines, a "gyors irodalmi termelésre“ irányított; hozzá anyagi ereje csekély, a mi a kutatás kitartó voltát, így mélységét is nagyon érezhetöen korlátozza.

Eötvös József a ,Falu jegyzőjé"-ben egy korszak sehét érintette hatással, de nem számaztatta le alakjait. nem is lehetett feladata. Az újkori szépirodalom, mely a népiest felkarolta, színez és a jellemzés gyöngéit népies szólamokkal isyekszik pótolni, inkíbb palástolni.

Ha ezekból ki akarnók hámozni a magyar nép jellemének azt a magvát, a melylyel visszakövetkeztetni lehetne az államalkotás és államfentartás föl-

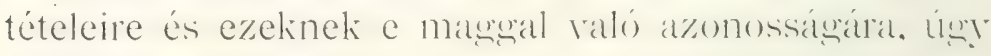
a czélt nem érnők el.

Ilyen körülmények között nines más módunk, mint bizonyos élö, vagy, ha ma már elenyészett, de a közelmúltban még megbizonyított nyomokon a mess\%e múltak felé elindúlni és azolihól a malgyan núp ösi jellemére következtetni.

keljünk tehat itra. 


\section{NOMÁD ÉLET.}

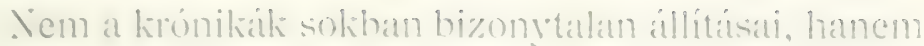
a maleyarsignak a közelmúlthan, részhen a jelenben is folytatott élete, enneli mozzanatai: csoportosulásat. felosztásil világosian arrat oktat, hogy a masyan nép az ösiségben momaid életet élt. \& houg jelleméneli kialakulásira a nomád vándoréletnek volt leutoöhin és leṣhatározottabb hatásà.

I nomádságrot jellemzó törzs- és nemzetségi s\%errezetnek nem annyira nyomai, mint világos tanúsád tételei még ma is kiválnak, igy és\%revehetók is.

A teljesen. ragy nagy többségr szerint egrazon csialadi neret felmutató falvak; a tanyarends\%ernél at sokszol népes, egyazon családi nerüi, törasök-nek is beillö egroségek által való megszállásá bizonyos terïileteknek; a sorok szerint való megszállás, mely egyes sorok más-más családi nevet riselnek: a hadak szerint való, egrazon családi nevet riseló csoportok megkïilönböztetése: ezek mind az ösi nomád élet maradványai, igy tanúságtételei is.

\section{SÁTORFA, ÖRFA.}

A mig a rezetó elem, mint dinaszta, pontoliat sxállott meg az elfoglalt területen s ott megretette lábát. nemzetségének gyökereit pedigg lemélýitette, addis a zöm ., fölütötte", majd ,fölszedte sátorfáját". Idóleşes foglalását megjelölte csóvásfával, majd örfával; hat pásztor. ha halász: ígı cseleliedett. A betolakodónali pedig odakiáltotta: , ,\$zedd a sátorfádat!.”

Honnan tudjuk ezt? A csoportosuláson kiviul éppen masúból az ösi szólásmódból: ,fölüitiotte - föjs\%edte a sátorfátát". vasyis: ,mestelepedett idöleresen, torább ment". És tudjuk onnan, hog̣ a múlt. XIX. század kiozepe táján mére divott a\% idölerges 
nomád pásztorélet s a halász is folyómentén vándorútra kelt.

A vándor-cserény fedett sarkának neve ,sátor", a beteg marhának külön, ,marhasátra" van. Fejérvámegyében, Sárbogúrd köruil akadtak igen öreg férfiak, kik a háromosztatú ósi izik — putri —- bejáró részét még ,sátor" névvel jelölték. A halász vándorútján sátrat ütött. Az ú.n., ,enyhelyet" alkotó könny̛ü, sokizor éppen csak takolt, szállithato szerkezetek, tüzvédök és szélfogiok, mind könnyen mozgók, helyet viltoztatók voltak és ilyenek, kevés ponton bár, de ma is. SZABAD FÖLD.

A legújabb megbízható kutatások ${ }^{1}$ arról tanuskodnak, hogy a földbirtok, mint magán- vagy egyéni tulajiłon, nálunk sokszorosan ij keletï; hogy a foglalás és újból föladás még a közelmúltban is folyt. Mindezek a mozzanatok félreismerhetetlen jelei. sö́t bizonvitékai annak, hogy a magya nép leg̣föh foglalkozási köreiben, a melyektől fönmaradása lényegesen függött, zöme szerint és az elfoglalt terület - különösen az Alföld — természeti sajátságaihoz alkalmazkodra momad loult és úgrszólván napjainkig̨ is, a töredékek tanusága szerint az maradt.

\section{NOMÁD REND.}

A vándor-cserény költöztetésének rendje, hatóságrilay megerösitre, még a múlt XIX. szazad másodili feléhen is rilágosan mutatja az és\%szerüen megillatpított egymásutánt és igy az ösi vándorlás rendjét is. ${ }^{2}$ Elól megyen a ménes - lovas haderö; következett

1 TAGANYI Karoly iratai; atvette MEITZEN is nagy müvébe: ,Sicdelung und Agrarwesen etc." III. p. 581. és tovább.

"Ennek és hasonlóknak bizonyítása maju csak az „Osfoglalkozások“ könyvében adható. Itt csak annyi, hogy a megállapitás hatóságilag Kecskeméten sikerült. 
at sulyar élelem: arutain a cserény situmtibor, a\%utim al coókmók ingo vatgron: végre at aprósige

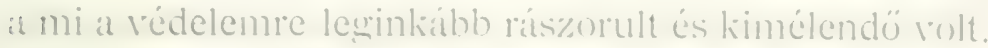

A kimutatott sorrend tanusigat szerint, de a dolong termérzetében is şöilierezve, at lovits haderön, innen a loron fordult meg minden : a foglalás, a megtartits. a rédelem és eşréb. Innen ered al ló kiváló meùhecsülése, mely napjainkign is fenmaradt. A lovasgazda rangban elébe rág az ülirösnek sia csikú a\% egés\% magỹar háznép beczéje. Ezek düntik el al lozus nomaid jelleget. A zagyon mértélie a szarvasmarha volt s a\% ma is: két-, négy-, hatökrös gazda.

\section{PATRIARCHÁLIS SZERVEZET.}

A népeket ismertetö komoly irodalom megeryezili abban, hogy a nomád népeknél šüliségképen ural-

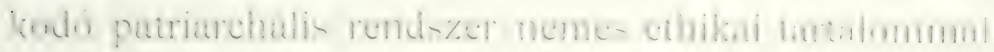

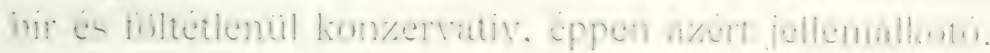
sajátossága szerint öröklödö.

A véneknek, a sátoralja fejének föltétlen tis\%tclete. ¿\% életkor szerint való alárendeltségr, a\% önér\%et, a becsületesség, a vendégszeretet, a józansás, a grijnsébbnek istápolása és védelme, a cseléddel, allattal való szigorú, de emberséges bánásmód és sok erryéb. mind a nomád sátrakat lakó erény és rásugárzik az egrtoron nomád magyarság mai jellemére is: jellemzó a tis\%tes liorral nörekiö hallgatagság nag̣ erényérel egyetemben.

\section{TERMÉSZETI SAJÁTSÁG.}

Há most már azt resszüik hozzál, hogl a malgvarság nomád életének területe kiválóan a malgyall Alföld volt, melynek kanyargó menetü, áadó folyórendszere jriási rétségeliet, a nádasok rengetegeit, a mocsarak. ingoványok escés\% világát teremtette és táplálta, és 


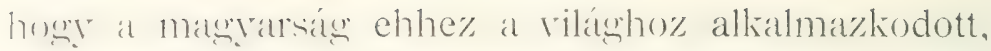
kïmnyen helátható úğ mešliözelithetetlensége, mint kitéréseinek hiztonsiana, ha a\% idók folyamán a reszedelem mégis megkörnyékezte.

Ezek a természeti sajátságok magyarázzák meg azt, hogy a nép a legnagyobb dúlások alatt is megmaradt és azt is, hogy jellemében - mert szokásaiban is - megrögzódött: a hatalmas természeti viszónrok elkïlinitok, elyarok, igs a régit fentartók roltak.

Tudnunk kell, hogy a rétség, nádas, a mocsár és az ingovány a népnek valóságos tápláló dajkája volt, mely fedelet, tüzelöt, állatjának buja legelöt, a vészbe és varsába halat adott; felkinálta a fészkelö madarak töméntelenségének tojását, majd fiát; az wmelkedetteh hely szicetet allotott, melyet csak az közelíthetett meg, a ki a járást pontosan ismerte; másnak az út biztos halál volt. A szigetre szállott ki a rétségbe ,kicsapott" szilaj gulya, szilaj ménes, rad kinndat és liemény fargrok idején ott gondoskodott róla az ember. Itt fejlödött a magyar pákász ósi alakja, mely még a mult század elsó felében is a legszabadabb nomád életet folytatta.

\section{TERMÉSZET ÉS JELLEM.}

Mindez és még sok egyéb, hatalmasan reáhatott a magyar nép jellemének kialakulására. A természettel és tüneményeivel való szoros viszony ráoktattat számos jelenség helyes mesitélésére si értelmet fejlesztett ott, a hol más népelinél a tudatlansíg csak babonát szuil.

Ez a természetben, életmódban gyökerezö sajátosság volt az, a mely a magyar népben hosszú

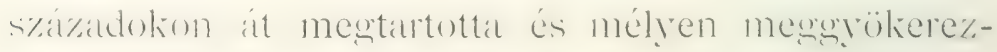
tette tulajdonságait, azokat is, a melyek egykoron 
allamalliotorá. ar idók folytan illamfentamtóví tették.

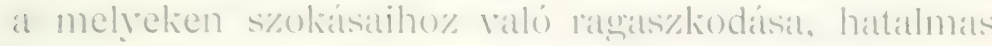
oinéryete ny̆ugsik, a mely megallottat s\%eme kilejerésében, mondhatni stugimásibin, a\% öss\%es allioto-

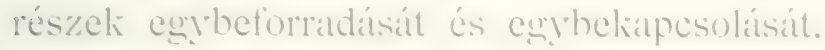

\section{ÖSI SZERVEZET.}

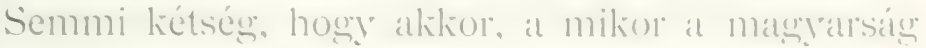
még teljesen nomád életet élt, tör\%si s\%ene\%ete volt, s

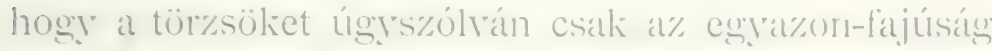
s a\% ebböl folyó eñrnemúsége a\% életmódnak és a lïzneli rehetö s\%olís kapcsolta öss\%e, a törsseli tehát egrmagukra nézve, vagyis eçyenként függetlenek voltak. Ebben a\% ösi szuverénitáshan liereshetö annak a hatalnals önér\%etnek gyökere, mely a maşyar népet jellemzi és éliesíti, de a mely idöli folyamán a kialakult társadalmi létben és keretben sokszorosan túlságba is vezetett, itt-ott el is fajult. Ë is kilövel a magyarság szeméból.

Ha az Alföldre, értve a síkot legészakibb végzödrényéig, még most is rávetjük pillantásunkat, legtöbb falvá, sớt némely városa is, sajátosan elhelyezett

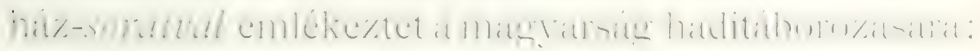
a hifejlödött tanyarendszert, mint atavisztikus alkotmányt pedig - ahho\% a szellemes mondáshoz alkalmazkodva, mely szerint az építés\%et diszességével keményre fagyott zene - azt a tanyarendszert elnevezhetjük a magrarok megfagyott nomádságánal.

Mint egrkoron az egyes törzsek és ezek keretében a sátorok patriarchális szervezetiokben föltétlen önkormány\%ati, mondhatni szuverén egységeliet alkottak, azon módon a mostkori tanya, arval a kiülönb-

1 Ext elsönck Hrawalo jegyezte meg. 


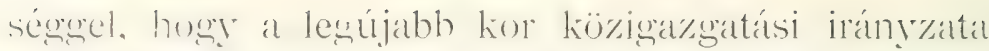

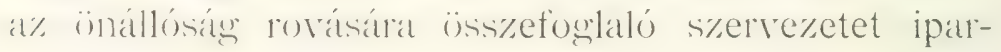
kodik adni a szétszórt egységeknek.

De azért a tanya ma is egység; belsö szervezete,

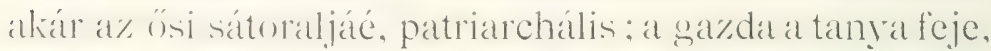

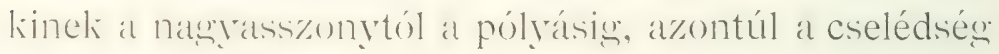
és minden fioltétlenuil alá valn retre. Ha a waizda a nagyasszonynyal indul valamerre, ö jár elöl, az asszony pár lépéssel hitráhb utana: a gazda viszi a\% ćkesebh bakót, az asszony dologidóben a terhet; összejövetelekre semmit, ekkor az ura kiméli. Legény, leány nem vághat elébe a család fejének.

Patriarchális rends\%er állott fenn a kïzrenden garadal és cseléd kiozoitt is: ery tálhól étlezett a felnött cseléd a gazdaral: cseléddé csak kïtelességei tették. Ebböl fejlödött ki az a jelenség, hogy a mag̀yar cseléd nem vált be uraságnál saolgának, belsönek éppen nem; mert önérzete visszatartotta a szolgai alázatosságtól, a feltétlen meghunyás\%lodastól. Itt crik egy kivétel volt és van, a mely jellemzó világot vet a lovas nemzet ivadékára: a magyar a világ első kocsisa, erre büszke, rajongva szereti a gondjára bizott lovat s érzi a rábizott drága jószásért, de guadája biztonságáért is vállalt felelösséget. A jó kocsis sokkal közelebb is áll a gazdához a legjobb béresnél.

Haladjunk immár tovább.

\section{A TANYÁS.}

A gazda a tanya egész életének sarokköve, tenwelye, ahs\%olut uralkodójil, de crak kivételesen zidrnoka; háza vezetésében a magaszörú emberek erós megszólásának van kitéve, a mire a magyar ember szerfölött sokat ad; ezt, ,nagyon szivére veszi“.

Mindig abban a meggyözödésben élek, hogy a 


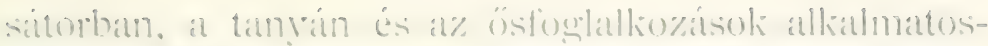
sigahan a fönek abs\%olut rendelke\%ési hatalma, nagy tekintélye göbereztette mego oly mélyen a monarehikus

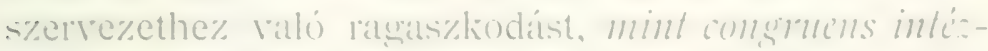
mcinyt. Erre még risszalérünk.

\section{ÖSGYÜLÉS.}

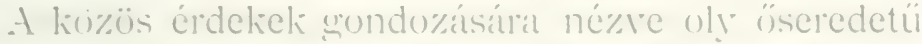
intizményt wámitok, mely csiak a liöelmúlthan ves\%hetett lii teljesen: de a múlt XIX. szizad utolsó hatmaldában még mesrolt. E\% à intézmény ar .ösprilles", mely a mostlori ..plebiscitum" másat süt ennél is mélyebbre ható. Fontos kïzüigyben t. i. a hol a kiizhizalom föl volt vetre, nem at törveny- valgy baimely jogssokás alapján jugosultak többsége döntött. hanem a nép salta, értve a\% érdehelt nép egretemét: férfia, asszonyá, mindkét nemú ifjúsága, le a gyerekig: ezelinel megregrezése határozott. ${ }^{1}$ Az ösgyúlés mindenkor teljes nyilvánossággal .. a\% Isten s\%abad ege alatt: tartatott meg: rezetett az, a kinek ahho\% való esze volt, a kirôl ezt általánosan tudták, a kiben éppen ezért al közbizalom öss\%pontosult.

A mióta a tanyák városi központokhoz tartoznak, kïzérdekben ezelihez vannak vonva, a\% igazi kïzügy azokon a bámulatos táláliozólion dólt el, a melyek vasiamapolion délelóttönként a székhár elött állottak. issse.

Ott dólt el à közüigy: noha csoportok alakultak a .hozzáillókból"s s a vagyon szerint rangosább at ransosabbal állott öss\%e. Innen a ,jöttment* töltétlonuil ki volt zárét.

A XIX. század ryolezvanas éveinek elején engem még ïsgyülés jelïlt Szegeden képwiselönek. 


\section{A JÖTTMENT.}

Ez a „jötment" rendkiviul fontos és jellemzö a magyarsíg felfogúsílra nézve, mert világosan mutatja. mivel és hogyan védelmezte meg magát a magyar nép az elvegyülés s így ethikai elgyengülés veszedelnétöl, a melynek foildirati és nemzetiségi elhelyezésénél fogra, küilönösen pediés áramló idegen tömegrekkel szemhen mint soks\%or kisebh szim is szazadok során ki volt téve.

Ha ez a "jöttment" eredetileg talán inkább csak arolirat a meröhen idegren eredetü elemekre rolt is értve. a melyek betolakodtak, vagy - késóbb - a magyarsíg nyakila kïildettek, védekeztek azért a legrmatgrarabb pontok egymás ellenében is. Debreczen még a legközelebbi múltban sem fogadta be — különösen társadalmi bizalmi állásba és körbe - azt a magyart, a ki a Basahalmon túlról vette eredetét. Ott élhetett, iparkodhatott, még holdogulhatott is; de at telirér dehreczeni czivis szemében "jöttment" maradt. És még ivadéka is, noha már a Basahalmon innen született, származás szerint csak „jöttment" ivadéka volt. A kivételek mindenesetre ritkaságok voltak, azok talán ma is.

\section{FELVÉG, ALVÉG.}

Azok az engesztelhetetlen ellentétek, a melyek tiszta magyar falvakban a „felvég“ és „alvég“ között tennallanak és még az összehazasodást is kizarjak, szintén erre a sorra tartoznak. Ilyen úton és módon fejlödött ki a mai, az erók egyesítésére törekvő áramlattal szemben, még pedig ósi eredetböl, a „partikularizmus", a részekre való bomlás, mely nem is kedre\%ett sohat natsy tarsaldalmi feladatok megoldasinak: de a nemzet sajátos helyzetében, a történelem folyásihan minden idegen eröszaklial szemben, mejg mint 


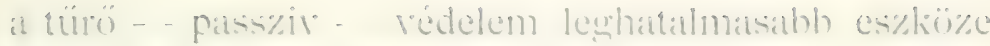
is bizonyult be. lay sokhan ho\%xitamult a\% atrany-

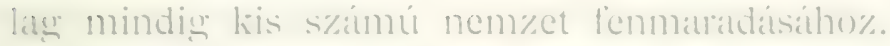

Itt és ezekhen talialjat ápolójit a\% a\% usi önér\%et.

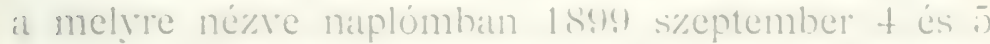

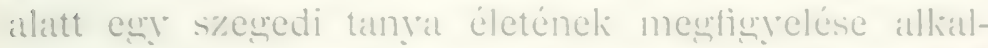

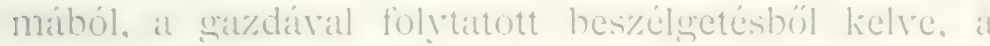
köretkezüt jesreztem föl: .. Ezek az emberek emelt fövel állanak meg király, herezeg vary bámi földi hattalmatsság és rang elött. habozáls nélkiül folvamodmak a s\%óhoz. bátran ejtik, mert ér\%ik, hoys a maşuk lanyáján éppen oly urak, mint amazok a matgulién. ha - lan mekik. De csakis akkor!..

\section{PÁSZTOR ÉS KIRÁLYNÉ.}

De ez nemesal at tanyásnál, li sokszor 10(0) 200 holdnyi birtokal kellös közepén lakik, így a mạgat nemében uralkodó, hanem a\% alsóbb fokon is isy van. Erre nézve élesen jellemzó példa az ezredéves kiállítás egrik pásztoremberének, öreg Dopos Sixuor, Kecskemét rárosá bugacz-monostori eserényes grulyásínak magatartása b. e. ERZSÉBET magrar királynéral szemben, ki tárollétemben FErEAC\% ID A magyar felolvasónöje kiséretében ellátogatott pásztorainho\%. mikor késöbb felkerestem a pásztorokat, feleségem é ¿\% öreg Dobos köjzött ilven párbeszéd folvt:

- Igaz az, hogy ö Felsége a matgyar királyné itt is jairt:

- Igaz hait.

-.. És beszélt vele. Sándor bácsi :

- Beszéltem hát.

- Hát miról :

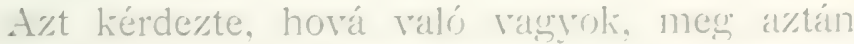
hány esztendó nyomja a vállamat? is is mondtam, 
hogy 48 év óta vagyok Kecskemét városa gulyása; ó meg rámondta, hogy bíz’ az derék dolog.

- De hát nem félt?

- Már mitül féltem volna?

Mégis csak nagy dolog egy koronás királynéval beszélni! Hogy is beszélt csak?

- Hát éppen úgy, mint most a nagyságos aszszonynyal.

- Hát Ferenczy IdÁ-val beszélt?

Akkor nem; de aztán magára gyütt ki ide. Hát mit csinált?

Ide ïlt le a gúnyás padra, aztán beszélgettünk.

Szivesen maradt?

Szivesen hát, hiszen nem is valami gyüttment, mer Kecskemétról való.

Mindez a lesnyugrodtabh hangon folyt és látszott. houg e\% ar oreg pásztorember ar egész dolgot nagron természetesnek találja. Abban a "gyüttment"-ben nyilatkozott meg saját önérzete is.

\section{TANYÁS, PÁSZTOR ÉS HALÁSZ.}

A kezdetlegesebb fokon, a hol a nomád állapot még nem dermedt meğ véglegr: pásztornál, halásznál egészen egyberágú volt a rendszer. A bokor elejének. a cserény számadójánali föltétlen hatalma rolt. Mindenben oly szabott sorrend uralkodott, mely még az étkezésnél is nemcsak az egymásutánt, hanem a\% eledel részeit is kinek-kinek megszabta.

Ha idegen közeledett, a fóember rászólt az elötörö ehre: ekkor eléhe ment a jörevénynek, üdrözoilte s felhistal, kerülne heljehh. A\% ädrözlés kéznyajutas volt, a kalaphoz senki sem myult; épp oly kevéssé, mint nem veszi le turbanját a török. 


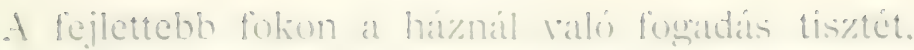
szinten a vendég elé valu menésel, at esialád teje

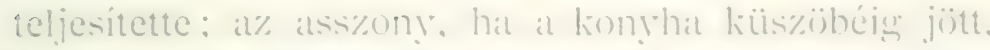
quribb sohat: at kïs\%öbüt nem lépte ait. A\% ats\%ony

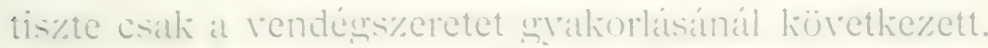

Etlen-s\%omjan senkit sem hocsitott el wazdat.

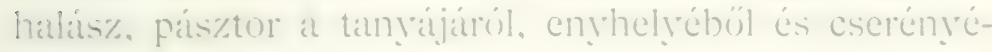
boil: hat merhalassa keruilt a dologs a lesjobb hely a rendémek jutott olivetetlenüil.

Ezek az errszerúl emberek csodílatraméltó komolysiduraral és méltóságrgal, valósátgosan ,reprezentálnak" Jem kivánesiak. nen alhalmatlankodnak kérdésekkel. mindenkor beérik arval, a mit a\% idegen maguról és szándéliáról maga mond. Igen éles megrigrelésre vall egrik irónknak az a megjegyzése, hog! -a nugyall mezei ember nem kiváncsi, nem törödik azzal, a mi nem az ó dolga, nem is megy oda, a hova nem hivjál.. Valóban így is van. De baj esetén. hivásra készségesen elöáll és szivesen segít.

Ezek az emberek tiszteletet tudnak tanusitani. alazatot soha - és semmi hizelgö s\%aruk nincsen: komoly. elismeró és virágos, sôt humóros az van.

Jellemzö és hiválóan szép az a meghivás, a melvlvel a Duna utolsó vándorhalás\% bokra meśtis\%telt volt. a melyneh közelében horgás\%tam. A mikor délebédre a halászlé a sgyepen tálalva rolt. felém jött nem ám a futosó. a bokor legkisebb embere, mert hiszen megtiszteltetésröl volt szó. hanem jött a\% öreślegrény köretségbe és ezt az üzenetet hozta: -. Tis\%telteti a\% urat a mestör és há nem vetné megr s\%egénysérünket, szivesen látjá egry hanál halás\%lére*. A mester 
érdemes követet küldött, evvel megtisztelte a meghivottat; de ö maga nem mozdult a helyéról, evvel bizonyította önérzetét. Ezt a dolgot szebben és méltó-rigosahban elvégezni nem lehetett rolna s ilyeneliben népünk valóban páratlan. ${ }^{1}$

Az alázatoskođó könyörgést ezek nem ismerik és ismét éles mestigrelés eredménye a\%, hogr: , t maşrar faj nem imádkozó. A kéregetés nem természete, még Istenhez is röstel minduntalan könyörögni".?

\section{A JELLEM ISKOLÁJA.}

A kérdés most már az: mi a magyar mezei ember jellemének az ösi öröklödésen felül iskolája, fejlesztöje?

Nincs nép, melynek gyermeke oly korán kerülne a nagr és sulyos felelóstég iskolágaha, mint a magrar gyermek.

Alig hogy a kis leány a füzvesszöt meg tudja suhogtatni, már kezére bízzák az egy folt ludat, a melylyel kiszáll a libalegelöre. Egy falat kenyér és valami kis hozzávaló, kendóbe kötve, ez az egész napra való eleség. És a gyermek megfékezi a korával járó mohó vágyat: csak akkor nyúl az eledelhez a mikor az evés ideje bekövetkezett. Ebben nagy fenvelmezo hatalom rejlik, mely a jellem alakulására irányadó.

Ez a kis $6-8$ éves teremtés felelös a kezére bizott jószágért; meg kell védenie a sólyomtól, sastól, kányától; meg kell óvni az elszéledéstöl, a kártéteitöl. Ez a gendoskodas iskolája. Megtigyeli allat-

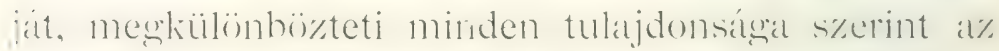

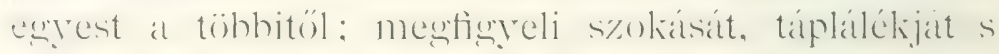

1 ๖. ö. „Mlagy. Halászat Könyve." I. 442.

* Eütrös Károlynál. 


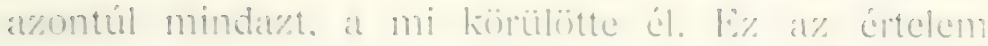
iskivlilit.

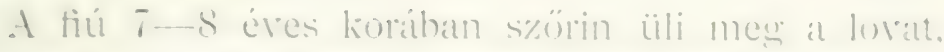
kiviszi parosan a legelöre. már éjszakitra is. I fele-

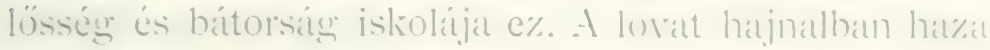

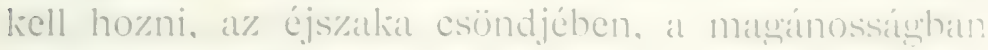
félni nem smabid.

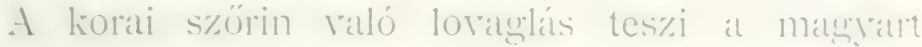

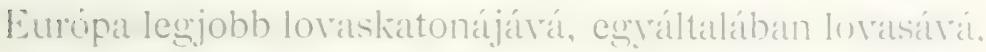
mert ettöl számazik a\% ú. n. mély zilés, mely s\%ép és biztos is. Ez a lábszáliesontolinak. medenczének. de a gerinezoszlopnak is bizonyos alkalnuzkodó alatkulásitol füigg. mely akkor a legtökéletesebb, a mikol ¿ șernuek méy idomitható esontrázán keletkezili. liell. hogy e riszony anatómiailag meghatáno mató legren. 1

Más lábas jószágg mellé advar, e\% a fiú kis\%áll hajinaltól alkonyatig; elesége szegényes vászontaris\%nváljában; legrơzi vágrát és mohóságáit és csak alikor" ny̆úl az eledelhez, a mikor annak ideje ran. irtelmét fejleszti a csillagrok serege, a "jó fü" ismerete. ¿ mezó apró állatviláğa, a rábizott jószádğ minden Sajáitságua, tulajdonsággà s ennek révén fejlödik ki a\% ¿ bámulatosan éles megkülönbörtetö tehetséğ, mely lehetövé teszi a juhásznak, hogry százakra menö nyájánali minden egyes darabját, egyéni tulajdonsát-

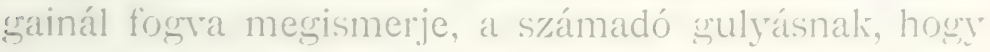
a\% egrves állatot esyénileg és grazdálál szerint bizton fojlismerje akkor is, ha a gulya állományáa e\%rekre rúğ. Innen ran a\%, hoss a magyar a világ legelsíj

1 Csak sajnálni lehet, hogy a\% -ijsszehasonliti anatrimia” maryar tanszékei még nem neveltek eröt, mely ily finomabls, a messze muiltakbat is «isszavágrj vizsgálatokban talilita volna megr hivatását. 
pásztora, legyen bár csikós, gulyás, kondás vagy juhats\%, mindig elsörendü. Legföbb és leghecsesehb tulajdonsága a hü gondozásra való hajlam. Nincs a természetnek az az égiháborúja, förgetege és vihara. mely a maśral pás\%torembert örhelyéról elmozditsat. Gondosan ügyel arra, hogy a „jószág ne törje egymást"; hogy "jófüves" helyen legeljen; hogy itatóhoz jusson; hogy ,megdelelhessen“ stb. A magyar pásztorember ismeri a jó és a mérges füvet, a jó és a rossz rizet, állatjának minden ellenségét, le a lesryek rilágáag; és nem egy jól ismeri a bognirság bonyolult átalakulását is.

A magyar ember elsőrendú állattenyésztö, ki a fajválasztást és tulajdonságok fejlesztését érti. Ėlsörendú állatismeró, hibálra és kiválóságokra, korra stb. egyaránt.

Órája derüis idóben a csillagok járása, ha borult az és, állatjainak riselkedése. Idöjóslása legtöbbször észszerü - ha északnak száll a téli vadlúd = meleg idó várható, ha délnek száll, hideg következik stb. Meg tudja nevezni minden állatjának testrészeit, szinét, jegyeit, ezeknek eltéréseit, a juh kivételével minden állatját néven szólítja. Ismeri a szabadban kïrülötte éló állatokat, azoknak életmódját, szokítsit. és nem költ reájuk semmiféle csodás, babonás tulajdonságot. Mindez és még sok más tulajdonsíg vilitgosan reá vall a természettel közvetetlenüil és folyto-

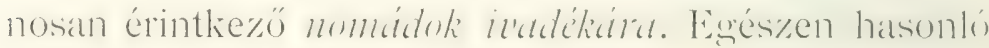
a halász is.

Mindezek és egyéb foglalkozási köreiben hasonlóknak tönérdekésége, éleseszüré teszi a népet, roppant

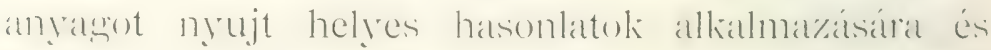
logikus kifejtésére. 


\section{A SZEMLÉLÖDÉS.}

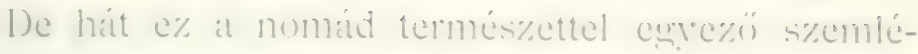

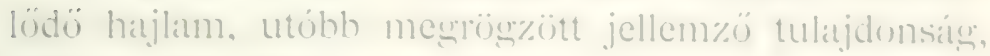

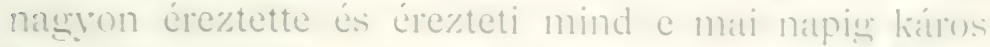

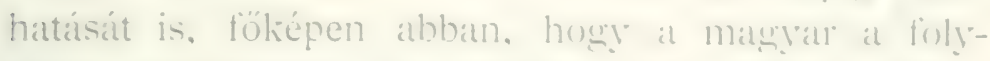
tomos szemessegret és ipartiodatst hijvetelö figmalkozaist. a minö a keresliedéssel és a\% ifamal jáll. nemesalk nem kedveli, hanem suks\%orusan matguhom\% illönek sem tartja. A természet törvénye elött megshaljik uggyan és ekkor hihetetlen munkát rére\%: de a mint ez megran, visszatesik s\%emlélödö illapotábà és csak a szüliség vas kénysiene alatt lát nuunkà utain. Legföltünöbb bizonyitéka ennek a jelenséğnek “ mezei munka. Magrarország búzatemö terüileténeh megrmürelése és az aratás, mint egrazon népréteü izonnerejére nehezedö munka, egrváltálában a legnnaryobbak és legnehezebbek közé tartozik; küilönösen ¿\% aratás, mely rörid idö alatt clvégrzendö és haloşatást nem tür, mint munká nagy és szerfölött súlyos. Ám a magỹar, a természet kényszere alatt .nekifullis zhodik és bámulatosan elvégyzi; de mindenképen azon van. hogr ez a nagy munka fedezze a\% egés\% ér szüliségletét. I mi a két aratás kijziöt idö manad. ¿\% is dolog - de nen iparkodás ideje. Nenzeti iparı. mely kezében vản. esak az, a mi a\% egrvliori nomád allapottal egrbevág: saru, irhás-öltözet, s\%ür-, nverewés szijjártó munkiá, a melyekben elsörendü: de prontatlan, halogató, més pedigr mindiós a fijld érdekében. Wint iparosnak is nem iparáak kifejlesztése. hanem

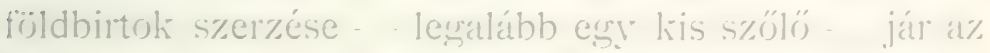
estében és mihelyt e\% megräan, mind hütelenchb les\% a szerszámhoz. A masran ember földéhsége hihetetlenül intenziv s ezen ât fejlödik ki erés\% ha\%as\%erctete. 
A folytonos iparlodást föltételezö kereskedést a magran

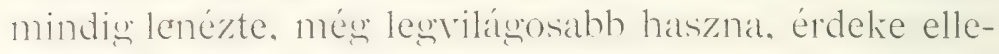
nére is másra, idegenre bízta. Ezek is a nomád lelkiilet megnyilatkozásai.

\section{A HASONLAT.}

A tapasztalatilag szerzett sok biztos tudás is hatalmasan hoziljarul ar önér\%et fejlesztéséhez és talan ez válik forrásává és rúgójává annak, hogy a magỷar s\%ereti a dolgoknak, tárgaknak sajat emberi roltátal való viszonyítását.

Ladikjának van orra, dereka, fara; korsójának van talpa, feneke, hasa, nyaka, szája, ajaka, füle és csöcse; kaszájának van orra, álla, öle - a nyélnek az a része, mely kaszáláskor a kaszás ember öle tájára szolgál stb.

És igen élesen jellemzö a hasonlat keletkezésének

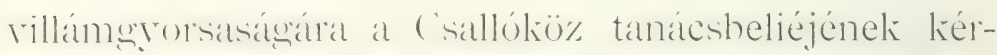
dése és megjegyzése, a melyet iskolalátogatáskor

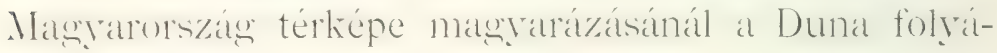
sára nézve tett.

Vácz tájára mutatva azt kérdezte:

Kinek hajt a Duna térdet?

Tehát a Dunának a nyugot-keleti irányból az

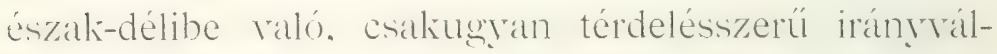
toztatását azonnal az emberi lábbal és térdben való hajlásával viszonyitotta. És arra a felvilágositásra, hogy :

Vácznak!

Azonnal megjegyezte:

..Akkor mi - a Csallóköz - éppen a Duna vitézkötésében vagyunk!"*

A vitézkötés a magyar nadrágon a czomb felsö részére esik, alakzata a térdfelé csúcsos, éppen úgy, 


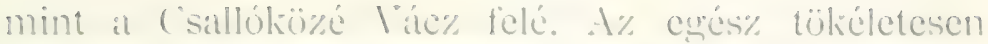

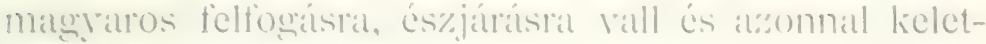
ic...itl.

A malsyall nem kerüli a vereledést: de nem hoss\%uálló, nem oresyillios és nines eset följegrezve. hogy áldozatát megkíno\%ta, kínjaiban gyönyörködïtt volnat.

\section{BETYÁRÉLET.}

Maga a magyar betyárélet, melynek syökere nem is ralami természeti gonosz hajlamban, hanem inliább bizonyos kényszerekben - katonafog̣dosás, eröszakos elnromatás, mély megbántás hatalmasok részéról rejlett, egyetlen vonásában sem hasonlított példálul a\% olasz brigantaggióhoz. A leghiresebb magyar betyátrok nem voltak öldöliló, kegyetlenkedó banditák.

Ellenben a legnagyobb mértékben ki volt fejlödve bennök a portyázó, rablásból is éló nomád egés\% jelleme. Kitünó lovasok, biztos lövök, a táij alapos ismeröi, leleményesek és ravaszok; ezen a\% alapon ki tudtak használni minden elönyt. Érzékeiknek élességre és finomsága bámulatos volt. A nagy betyároli és haramiatásaik nem is annyira a társadalom. hanem a hatalom ellen keltek; a legnagyobb vakmeröségrgel megütköztek a hatalom embereivel és mestereli roltak a síkion való eltünésben, melynek minden hullámát ismerték. A betváréletbe egryszer belekerülve. a társadalonmal szemben a szükség bírta öket eroj¿zakial; a hatalommal szemben a végsóig menó önrédelem. És az, hogy a kis embert nem bántották, szörethezre avval, hogy harczuk sokszor gyülölt. idesen hatalom poroszlói ellen folyt, vákmeró volt,

1. Ezért az éppen oly jóizü, mint jellemzó) adatért Banтosm: (iè\%i-t, a1 Eötvïs-kollégium igrazgatójąt köszöntöm. 
sôt sokszor nagy hósiesség szinét viselte magán: minde\% a maşyar népet a nagy betyárok bámulojárá tette. Fy a hámulat fakiatsztotta a nép költészetre hajló lelkét szóra, dalra is.

De ha a jelenség lényegét vesszük, úgy fogjuk találni, hogy a nép, maga is érezve az idegen hatalom nyomását, mely sokszorosan kényszerben, zaklatáshan, igazságtalansághan, önérzete megrgyaláásában nyilatkozott, a saját elnyomatásán és üldözött voltán át tekintette a betyár helyzetét és összekapcsolta a maga érdekét a betyár cselekvésével az ellen, a mi közös gyúlöletük tárgya volt.

\section{SIRVA VIGADÁS.}

A szálló ige azt mondja: "Sírva vígad a magyar.". Az bizonyos, hogy rigadásinak két legööhb formátja: táncza és éneke mély, bensö indulatból fakad, sohasem valami egyoldalú, folytonossággal ráható idegingerból. Képtelenség még el is gondolni, hogy a magyart, mint a különben zárkózott délszlávot, a guzla egy húron való rithmikus, de egyhangú czinczogása lázba ejtse és oly ugrándozásra bírja, mely meró ellentéte rendes kedélyállapotának, a melyre ebböl kioretkeztetni merö lehetetlensén. Es a magrat nép tánczar semmitöl sem kïlönbüzik sö̈keresehben. mint a német, tót és oláh táncztól. Füizéres, ugrándozó, rángató, a tánczosnét össze-vissza forgató, emelgetố részei nincsenek; a szálló ige értelmének megfelelöen lassúval kezdödik és vígba megyen át; a lassúban van méltóság, a víg részben tüz, mely a heresebh termúszetü legúnynél kurjantásban. númely helyen - kivált a székelységnél - egy-egy ú. n. tánezsioban nyilatkozil. I támezso lehet dévajkodi. néha csípös, sohasem durva és - népies értelem-. 
hen - illetlen. Mén at lewszilatjab lewény is esing ján banik tanc\%osnöjével. Datey allialommal a korosabbak is tanczral perdülnek és iṣen natgy tisztességerel, komolysíswal járják. Jellem\%ö az, houy minden fürtinek megran a magra nútája. \& hogr tanc\%\%onében egyil-

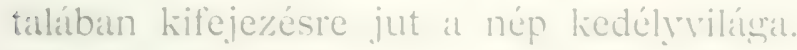

\section{TÁNCZSZÓ.}

Rendkivoül jellemzü a\% ér\%elmek hullámzásà akikor. a mikor az ifjú magryal a leshatalmasabb ösztön, a szerelem hattálial alatt áll. A\% éryelem keletliczését, tetözését és a réssoö kifejlüdést a tánczszók sondosabb tanulmányozása adja meur nekünk. A sol ím e\%:

Ifjak ragyunk is nem tehetjük, ${ }^{1}$

Hogy a leanyt ne szeressuli.

Ez a szerelem ösztönének és hatalmának kifejtése és most hörethezik a szerelen tárưar mint érintetlen, ..stildö* leánỹ:

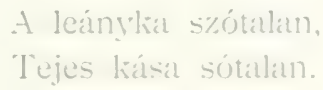

Az édesnek tehát se szala, sem sava. Köjetkezik a\% érzelem ébredése:

Esy legény corak hozzinyult,

$\rightarrow$ a kis leany elpirult.

A kifejlödés eselekvésben és az ártatlanságnnál telmészetes köretkezményben nyoilvánult. Ime az elhatainoúts :

Ezt at leán yt elkiserem,

.láho\% esy hét mes is kérem.

De beáll a kedvezótlen bonyodalom s ekkor:

Mély at tenger, azt jól tudom,

Je mélyebh à én hánatom.

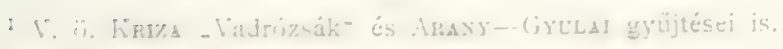


Felébred azonban a férfias dacz:

A kalapom fére vágom, Kifogok én a világon.

Beköretkezik ennek túisága is, mely alatt azonban bánat lappang:

Nem tûrök több bosszúságot,

Tovább rúgom a világot.

Legvégül következik a lemondás:

Szeretem én a babámat,

De még inkább a hazámat.

Ez a végső kifejlődés rokon a Petőfi Sándor e mondatával:

Szabadság, szerelem,

E kettő kell nekem:

Szerelmemért feláldozom

$\mathrm{Az}$ életet,

Szabadságért feláldozom

Szerelmemet.

Természetes, hogy a közrendú magrar legényouél a szerelem és a hazaszeretet más alaphól indúl, mint a forradalom költőjénél, ki egy nagy korszak eseményeinek kialakulására egész lelkïletérel hatott és el is fogadta a hazaszeretetért a halált.

A csalódott legény, a kijzretetlen felindúlás eseteit rére ki, nem ragadott fegrvert, hogy a hütelent ragy vetélliedö társát elpusztítsia, hanem - különösen régehben elkeseredéséhen felesapott katonának, mi akkor egrértelmú rolt a messze idegennel. De az a haladvány. mely a nemzetet a legmagasaho pontra helyezi, tényley és nemesalk tinnezszóhan. hamem at lestomolyath formában, a halladihan is megran.

A Kriza Jínos gyújtötte balladák között a „Ke- 
rekes lzsalk"-féleben a hös a csattihat indulloa, ily hallatvimyban tünteti tel leyhensiobb ér\%elnet

Kinntom veremet apimert, ansiment.

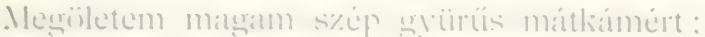

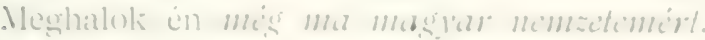

\section{MONDÁSOK ÉLE.}

Halidjunk toribh.

Rendkivüil jellemzö a lapidaris rövidségú mondásolinak tartalma és ebben a masyar nép elméjének éle, mely kevés s\%óban az indulat minden formáját és tokozatat ki tudja fejezni. A fokozat, a legenyhébb humortól a legmaróbb ýunyon át a tiszta büleseségyig ér föl.

A tánczszóban a legény a tömzsi, vastag leányt igy csipkedi :

Edes kicsi, kurcsí hogrom.

Derekalat ëlbe foesom.

A czitrálkodó igy kapjá ki:

Hol a ruha kazimér,

Nines az asztalon kenyér.

A mi egrértelmú cvvel:

L'ti czifra, házi russ\%.

A megróvó gúny így szólal meg:

Fut a hazugság elötte $=$ mindigr hazudik.

Xem keveset iszik, hanem soliszor = korhely.

Hónod alá tedd a nyelied = ne fecsegj, meghánhatod.

Vargy iorommel panaszolja, hogy meghalt a

felesége = liépmutatás.

Kormos Pista derék legény,

Eury kötelet megér, szegény = maro gúny.

Tánczol a pap, jégresij lesz,

A szép buzím mind odares\% = nem babona, hatnem intes a hivatés livietelte illendröserge. 


\section{TALÁLÓS MESE.}

Megnyilatkozik a magyar nép elméjének éle a találós mesében, melyben solis\%or liedres a játsziság is.

Ha vize van, bort iszik; ha vize nincs, vizet iszik.

(A molnár.)

Nem csinálják, mégis lesz.

(A hasadás.)

Hold elcjti.

Nap felkapja.

(A harmat.)

Neked ran, nekem is ran,

Kertben kis kórónak is van.

Mikor fél a nyúl ?

(Árnyék.)

(Mikor ketté vágják.)

Melrik oldalára esik a nyúl, ha meglörik?

(A szörös oldalára.)

Miért iszszák meg a bort:

(Mert nem kell magnak.)

Melyik oldalán van az ökörnek több szöre?

(A melyilire farkát csapja.)

Hányat tojik a pipiske?

(Hol többet, hol kevesebbet.)

Van leíró találós mese is:

Amoda mén tipetopu = (a szamár patái kopognak) Hátán viszi genyegúnya = (bundán ül a juhász) Szeme négy, füle négy, \ embernek, állatnak Körme pedig huszonnégy i együtt.

(Juhász szamáron.)

Akad igen mélyértelmü is:

Mi a legnehezebb dolog a világon ?

(Várni, nem jönni; lefeküdni, nem aludni.)

Legyen elég a következő mondásokkal:

Ki minek nem mestöre, hóhéra az annak.

Reggel táncz, este láncz.

Nagy ember ha botlik, nagyot botlik.

Jobb a kevés enyém, mint a sok másé. 
NÉPKÖLTÉS, DAL.

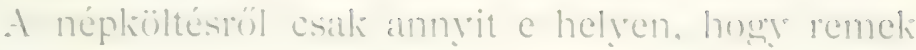
hallatalion ke\%dre, at egretlen jats\%i stroblat is felöleli: teli valn saljátos hatngulattal, wyönyourü rithmussal és Releties stinességrel.

Dalatban mégr inkíbh. Ėekben nem a tïhbhangú ének hammóniájajar, hanem a tartalommat fektetik il

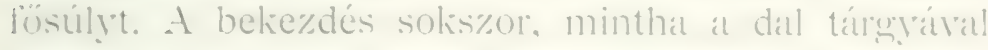
ös\%etügrgéshen sem volna, mégis az: de c\%élyalta s\%erint solis\%or igen rejtett és mély értelmü. Ama nére at mi a nép eszejárásánali. formaéryéliének, liedélye alaphanwulatának, szóral szellemi sajátosságránali megfelel. nines nép. a mely oly ürorsan és oly teljesen befogadná költöinek megrelelö dalait. mint a magrara. s ha itt-ott idomit. ez inkább a forma rovására esik, az értelemre nem. mert ez ragadta meg lelkét. E\%elikel azonban nem azt mondjuk, hog̣ változatok kelethezése ki van záråa: akad bören, mert a népnek sohasem nyugró alliotó szelleme él és eleven. E\% a šellemi téren is kizárja a merer változatlanságot. Naya a magrara népkijltés, szólásmód, példabeszéd stb. egry kimerithetetlen tenger. melynek legnevezetesebb tulajdonsáya az, hogy eryetemes. Nem mutatja azt a sokszor mero ellentétbe menó tagoltsáưot, a mit más népek s\%ellemének mes̀nyilatlozása nyujt. A mi tiszta népies magyal, az lehet minden, csak szentimentális nem: a miben pedig tetöz, az a sajátos masyar humor, melynek a költészet terén eddig csupán ergy föltétlenüil mašrarus kifejezöje akadt, a részben ezért is lefordithatatlan Ar.1.Y divos. MÜVÉSZET.

Sokszoros állitásokkal szemben, melyek a matgralltỏl a müvészeti hajlanot elvitatták, vagy azt kétségeneronni iparkodtak, áll a\%, hoggr a magramak rilágessan 
megnyilatkozó mürés\%eti hajlama van, mely sajatos és

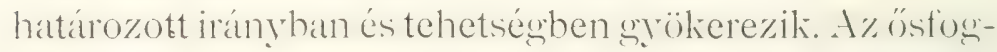
lalkozások azok, a melyek ezt nyilvánvalóvá teszik. I kifejezett kétségek onnan eredtek, hogy a magrarsagot legiellemzöbb foglalkozási kïreiben nem kutatta. igy nem is ismerte senki.

Ott, a hol a fa és a fém hiányzott, mint a nagy

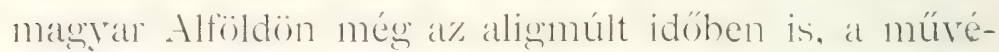
szet szinvonalát üiötte meg igen grakran a börböl vale fonás és a fonval-kötre való diszités, mint pásztormüvészet. Ott, a hol fa és fém volt, mint a túladunai rész-

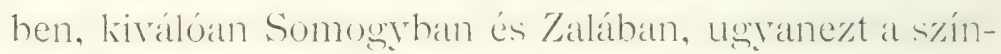
ronalat ütötte meg a faragás és rajzolva diszités, šintén mint pásztormüvészet. Így mind a két ágazat nomád eredetü.

Meröben dísztelen csak a halász, mert mesterségének egész lénye szerint arra kell törekednie, hogy s\%ersamja föl ne tünjék, heleolvadjon környezetébe. Itt nem az ékersés. hanem a furtangigy kimivelt czélszerüség a döntó, és ez a 1nagyar halásznál tényleg ritkítja párját.

\section{AZ ÖSSZEHASONLITÁS.}

Az összehasonlítást megnyitjuk azokkal a fejtescetésekiel, a melyekkel a Kelet vilighnirü kutatoja és a\% élók között talán legalaposabb ismeröje, I imbik Arms megajándélozott s a melyeknek teljes tartalma a következö:1

\section{MAGYAR ÉS TÖRÖK.}

,Azokból a szellemi tulajdonságokból, a melyek a

1 VÁmbér kiséró levelében világosan mergjegyzi, hogy a magyar népet tulajdonságai és szokásai szerint nem ismeri eléggé ; igy összehasonlitisáhạn a súly a középázsiai clemre esik, a melyet alaposan tanulmányozott. 


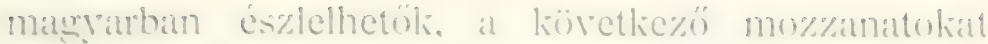
atkarom összehasonlitani a\% általam évelien at tanulmánvozott török népeliéirel.

.. Hat al magyar paras\%tot kö\%elebhröl vi\%suiljuk. azonnal s\%emünkbe ötlik komoly, méltúsátğos mes̀-

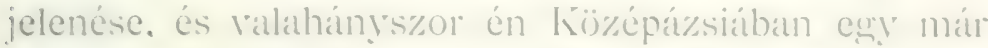
korosibb özbégret, turkománt vagy kirgizet láttam. mindannyiszor feltünt nekem a hasonlatossidg a mi matry parasztunklial.

\section{KOMOLYSÁG, LOVAGIASSÁG.}

...t török ember az ugrálást, a kiönnyü bes\%édet megreti, ezt komoly férfiúho\% illönck nem találja.

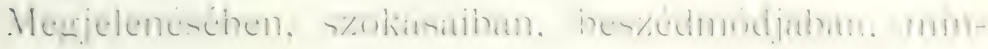
denben csak a méltósátgot tartja szeme elótt.²

. I'alamint a középázsiai törökbool bohó, ugrándozí ember nem válik, sót ezt szégyenletesnek tartja, igy van ezekiel a mi parasztunk is.

.A mi hözrendü emberünknek egrrik fötulajdonsága a lovagriasság, de az evvel együittjáró úrhatnámság is : l'syanez megvan ázsiaszerte a töröknél is.

... t török ember orozva ritkán vagy sohasem grilkol és nvilt erószakikal reszi el azt az embertól, a mi neki kell; lopásra nem adja mayát; söt azt mondja: lopni fértiúhoz nem illik!

.Mint lovagias ember megtartja és bevaltja szavát és csak a zsamokság teheti álnokká és cselszövoóvé.

'Igen érdekes az, a mit csak a leghözelebbi napokban - 1942!. arattáskor - Sct. George MaCaulay-Trayelyas küzvetetlen tapasztalásból a magyar aratri-munkásokról mondott: ,.Mily becsületes, jósígos arczuk van ezcknek az embereknek!" Egy országban sem oly rokonszenvesek a munkảsok, mint a magyaroknál. Valami biiszkesés is millösár van az urczukon. Ilás országok munkásainál ez nines meg; azok vagy a tulságig alázatosak.

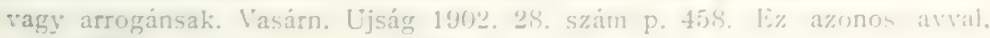
a mit Rersinar asszony mir 1806 -ban megjegyzett.

" Laisd hátráhb a táhlahiró jellemzísénè]. 
„A mi parasztunk nem riad vissza a verekedéstôl, jó katona válik belóle; de olasz bravo nem lesz belöle soha.

\section{ÚRIASSÁG.}

„,A magyar épp úgy, mint a török, mint úr szeret megjelenni, ritkín hunyászkodik meg eóljárósága elött, szembe néz azzal, a ki elöljárója; de tiszteli, ha tisztakezú és törvényes alapon, vagy a bevett szokás szerint cselekszik. Magyarországon a tót és az oláh az úr elött leveszi süvegét, ezt egyik kezében tartja, mig a másikkal fejét vakargatja.

„A középázsiai özbég megáll kahánja, fejedelme elött, illedelmesen és hitran heszél és ritrán gürbül a háta; azon módon a magyar közrendú férfi is.

,Evvel kapesolatban áll az is, hogy a török uralkodó faj soha kereskedóré nem válik, at pénzszerzést nem érti és iparos is csak ritkán lesz belöle. Ez, fájdalom, a magyarnál is így van.

,A török mindenütt uraskodik; söt van példaheszéde, inhíbb szilló iréije, nely ezt mondja: .. Kincset Indiában, észt Európában, fényt és úriasságot Törökországban lehet csak találni." Evvel az úrhat-

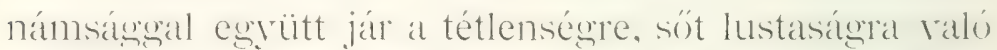
hajlandóság is. A török éppen úgy, mint a magyar, ha arra kerül a sor, tud dolgozni, de el is tud sokáig: dologtalanul ülni s álmodozva tölteni az idöt.

,A keleti ember, a török, a nök iránti tiszteletben kitünik s ez a magyar természete is; sôt ez a nöt "fehérszemélynek" mondjat: a török is . akhaslik. elnevezéssel illeti, mi fehér fenyöt jelent és megkülönböztetés a folytonosan a szabad ég alatt élö s éppen azért barnított arczúl férfiaktól. 


\section{ESZESSÉG.}

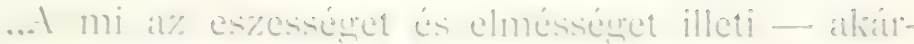

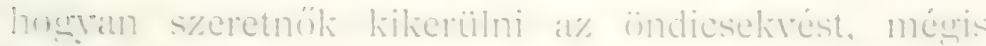
mey kell vallanunk, hogy a mi matgrat parastunk.

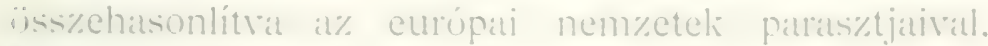
határomttan es\%esebh és elmésehh. A franc\%ia paras\%t atr\%inn. mikor azon fatczipösen at templombat lép. igen

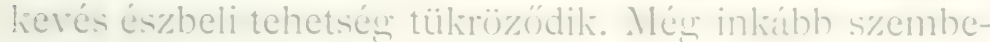
sziiliö e\% al ..Platt” németnél és nem lievésbbé a\% angolnail is. Az angol hözrendünel s\%egletes, nehé\%hes modora nem igen vall arra a nemzetre, a mely at müvelödésben annvira fejlett: míg nálunk a vágries\%ü és elmés faraszt igren grakran meglep finom és\%"eriteleivel és józan itéletérel.

..Ha összehatsonlitjuk a nép beszédmódját. annali relös mondátsalit. fordulatosságát másolikil, elmondhatjuk. hogy nines Európában kïznép. a mely annyi relös mondást, annri és oly szép, ékes szólásmódot fel tudna mutatni. mint a magyar nép és rele csupin ¿ helet népeit. különösen a törökö̈t lehet ïss\%ehatsonlitani.

... Átalálnosságrban ki lehet mondani, hoụ minél messzebbre newrünk keletneh, annál inkáhb jelentleziliés nüreliszik a lieleti népeh eszessége. A perzsia

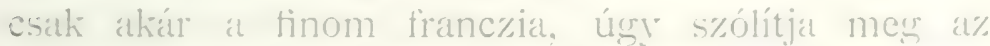
embert és épp oly ügyes és fordulatos a társalyásban. At törijk azonképen. Logranezt a magräar népnél is észlelhetjük. A magyar nép értelmi tekintetben tetemes magasságban áll a hörüiöjte lakó nem magral elemek fojlött. Az eróteljes nyelvezet, a népliojltés\%et a magrarnál teljesen heleti jellergü és herés atiad benne, a mi Európara emlékeztetne. 


\section{FÉNY, HAZASZERETET.}

„Ugyanez áll a külső fény, a czifraság szeretete dolgában. Ebben is tiszta keletiek ragyunk. A szinek szeretetében, a fényüzésben - mint az idézett szálló ige is mondja -... egészen a törökre vallunk.

„Szóljunk a hazaszeretetrő! is. Mindenki szereti azt a földet, a hol született; de a török és a magyar ebben mégis túltesz minden általam ismert népen:

\section{EREDET, HÓdÍTÓ TULAJDONSÁG.}

Számtalan mozzanatból ki lehet mutatni, hogy a magyar nép alaprétegében, a közrendben igen sok oly tulajdonság van, a mely tisztán keleti eredetü és a melynek a nyugathoz igen kevés köze van. Ha azt kérdik, mi ennek az értelme? a felelet nagyon egyszerú. A nép mindenüitt konzervativebb, mint a magasabh rend. Mikor a magrarok ebbe a\% országba jöttek, az alsóbb magyar néposztály számra igen csekély volt. Búmennyire mosolyogjunk is különben? a régi Werböczy szaván, hogy minden magyar nemes és úr, abban semmi kétség, hogy a honfoglalás közben a magyar parancsoló és mindenüitt irányt adó volt.

$\mathrm{A} z$ élet felfogásában és mozzanataiban a meghódított népek hozrásimultak ús így a hódító szelleme. a meghóditott népelemekben még igen sokáig fenmaradt. Ennek megrelelöit latjuk Ingolorsighban, a hol a norman hóditók egyes szokásai még ma, hatszáz év múltán is élnek az angol nemzetben - és látjuk spanyolors\%aghan, a hol a\% araboli erres s\%okásai még ma is feltalálhatók a nép alsóbb rétegeiben. Az pedig teljesen világos, hogy a honfoglaló

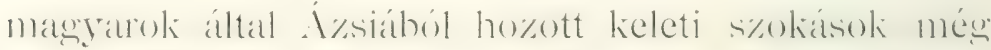
mat is feltalithatok at masgrar nép alsohn rétegéhen. „Nem szabad felednünk, hogy a szokások nem- 


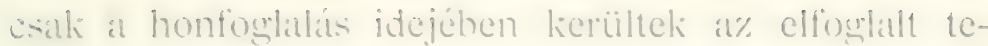
riiletre, hanem bes\%ivilugrate liésoubhen is. A\%siaból

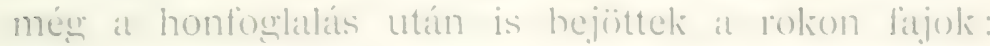
kunok, besenvoóli és tatail elemek, at kili fel-felujitottaki a régi dissiai emlélicket és al leledésbe merülö s\%o-

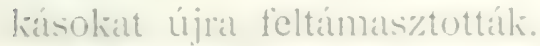

. Erdekes és fontos pszicholouriat tanulmányt lehetne ezckböl takiatsztani: de csak akkor, hat nemesak it matorar, hanem a rokon népeli soliátsait is alaposan ismernök. Semmi kétség. hogy a\% ïssichasonlító módszer ezen az alapon sok fontos tényt deritene foil.

\section{ZENE.}

.. t zenére vonathozólag is all ar, hogy a ma¿rarolié inhább ázsiai, mint európai. A masyaroli zenéjüiket magukikal hozták - tzsiából.

...t mi a\% eddigiekben a népról, a kö\%rendröl ván mondrá, azt az úri osztályra nem lehet allialmazni. mert e\% az idegen müvelödés emlöin nevekedve. eg̣és\%en nveugotivá vált.

\section{VISELET.}

...t riselet dolgá a körethezö szempontok alá tartozik. Az úri ruha, mint tudjuk, csak a mongol hadjárat után. tüzetesebben meghatátroza, a XV'-dik században kezdett elterjedni. Mindaddig, a mint at a krónihák lépein látjuk, tisztán keleti volt a magry ar úri ruházat. A magyar közrend bó gatyája, mint tudjuk. szintén régri keletü. A bizancziak történetéböl tudjuk. hogr a crörög szokésok az avarok alatt mát elterjedtek Pannóniában, velök a görög ruháă is. Ennek a szoknyaféle bö, görö̈g népruhának, melynek neve ,fisztan", hasonló mása a masyall gaty"á, avval a hülönbségrgel, hogy e\% utóbhi hosszabb és bövebh $s$ az inge is hosszabb. A szür; at suba, a süleg é 
kalpag-szintén ázsiai eredetú; a sisak ellenben már európai átvétel. ${ }^{1}$

\section{NÉPIRODALOM.}

„A magyar népirodalom egyik részét tevő találós mesék és mesék annyira egyezők a török irodalombeliekkel, hogy átvételrôl is lehetne szó. Van gyújteményemben kïzel liétšà magyalr példabeszéd, a mely Küzépázsial népeinek példabeszédeirel teljesen egybehangzó.

\section{SZÁM, KULTÚRA.}

„A magyarság csekély számban jött ide be; de müreltsége nagyobb rolt a\% itt talált népek kultúrájicinál, a minthogy akkoron egyáltalában nagyobb rolt ez Ázsiában, mint Európában, és így -- ismételten mondva - nem csoda, hogy ez nagy, irányító befolýassal volt az itt talált, alantasabb múveltségú népekre. De ebból az is folyik, hogy a honalapitó magyarok nem voltak barbárok.

„Abban semmi kétség, hogy Szent Istvánnak és a nemzetnek a keresztény hitre való megtérése és ennek révén a keresztény múveltség. mentette meg a magyar nemzetet az elpusztulástól".

Eddig VÁmbéri.

Tiszta és világos, hogy VÁmbéri fejtegetésének eleje, a hol összehasonlítva halad, minden ízében a nomád nép ethikáját adja mindkét félre nézve.

Ehhez csupán annyit lehet és kell hozzáadni, hogy a keresztény múveltség igenis megmentette al nem-

1 Pauler Gyula "A magyar nemzet története" czimü pályanyertes müvében ezt crôsiti: „A mai paraszt jelleme, külseje, kezdve a prémes kucsmán, a bundán, a szoknyaforma, habár többé nem is bör-, hanem vászongatyáig, a hegyesorrú nchézkes csizmáig czivilizáltabb, de nem degenerált hasonmása a honfoglaló magyarnak." Im ez is egy szakadatlan sor! 
zequt a\% elpusztulistol: de mennentette a\% is, a mi

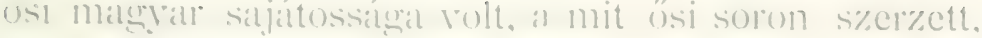
s a mi a lieresztén müreltséurel megrérve, biztositotta al nem\%et értelmi és e\%\%el hatalmi heremoniáját.

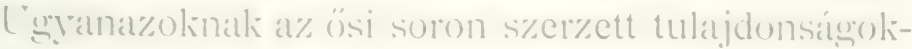
nak birtokíban maradt al kö\%elmúltig a\% úri kïzéprend is. mely ezeliból at tulajdonsiagoliból meritette minden erejét, eszküzét, valahányszor a\% alliotmámyt megr kellett védelmezni. Ë is kétsértelen.

\section{KÖZÉPREND.}

A jellemre ronatkozó fejezetben a magá helyén megjegreztem, mily nayg rolt a\% érdekkölesönösség al magrar rezetö elem és a nép zömének szinnaugrar része kïzött. Az ok nagyon természetes. A\% „úri középrend" maçasabb müveltségével állott helyt a\% alkotmánynak küilsö vonatliozásáiban való és a\% osi juss és szokás rédelmében; de mindig a zöm "osi sajátosságaira támaszlodra. Ez a viszony szülscégszerü, de természetes is. A magyar "úri förend" más szempontok alá tartozik, mert hatalmi érdekból vér szerint lönnyen vegyüilt.

Legrtömörebb és legtalálóbb jellemzése a\% ignati magyar úri középrendnek íme e\%: ${ }^{1}$

.A- tisztavérü magrar nemesi családoknak sok erényük és sok gyöngreségüik volt. Erösek, büis\%kék. s\%abadok és fügrgetlenek voltak; hazatias, hadi és családi erényekben gazdagok. A hogy WAlTER Scot"T jellemzi a középkori sliót várlakó urakat és nemeseket, olyan rolt a magyar. A királylyal s\%emben bátor és jogarédö. Az alliotmány esorbitását megr nem engsedi. Szabadsásait, kiváltságant életre-hatálrà védi. 
Fajait tisztan tartja. Országát ellenségtöl szakadatlanul oltalmazza, s vérét, vagyonát nem kiméli“.

"Voltak jobbágyai. Ezek fölött az alkotmány sok joget hiztositott a nemes úmak. Volt alkalma paranesolni, kormányozni, csiaknem uralkodni. Edzett testalkat, ragyoni jólét, a szabadságharezokban hösiesség. a radászatokhan batorsig, a közüugrek rezetésében šabadsíg és függetlenség: ime, ekként támadtak. igy fejlödtek köztük az erôs egyéniségek".

Lehetetlen, hogy ebben a plasztikus képben a kïzépázsiai tartalmat föl ne ismerjük. Annak az elemnek pedig, a melyet ez a kép jellemez, utolsó képriselöit mi öregek, a kik elsö emlékeinkkel a XIX-dik század elsö felében gyökerezünk, mondom, annak a képnek élő másait még ismertük.

De van e képnek visszája is, ím ez:

„Néha eltorzult a fejlódés. Vagy az agyban vagy ar erkölcshen hiba támadt. I ragyoni jólét tékozlássíl. a hatalom zsarnokoskodásiśa az innérzet goögoné és hetylieséggé, a függetlenség betrársággá fajult".

Ezeket is ismertük, szemünk láttára törtek meg.

Ugyancsak a magyar úri rendnek legtanultabb része jellem szerint ez volt: ${ }^{1}$

\section{A TÁBLABIRÓ.}

„A magrar miveltséget természetesen csak Magýarországon ismerik. Alapja ennek az ú. n. klasszikus míveltség, a hellén és latin remekírók szelleme. Ez megvan minden más mívelt nemzetnél is. A magyar miveltség különössége azonban abhan illott. hogy a šmdolkodó elme a\% állami kïzélet naỵ kérdéseit. az alkotmányjogot, a korona hatalmának becsét, a 
titsidulmi os\%tilyok kïzt lévö vis\%onyt, a\% emberneli

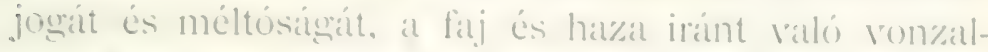

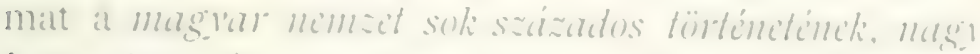

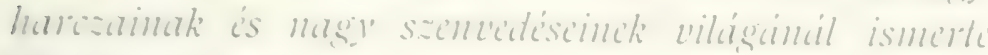

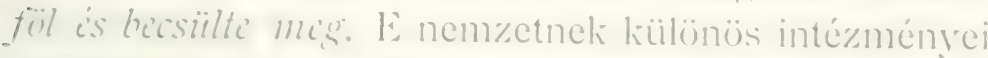
voltak és küilönös története, mely a\%okiat a\% inté\%ményeket megalakitotta. A fạj is más, mint a vilingnak bammely más mivelt fajja. A nvely is különös. minden közeli rokonsáğ nélkeiil való. Fyeréves története is különös, minthogy a tatár, török, német és

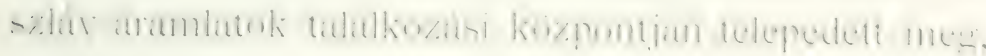
$s$ ezek minden harczát régigharczolta. Mert a hare\% elöl ki nem térhetett, de számának cschélységénél fogra legragyogóbb grözelmeinek has\%nát se élve\%hette igazán“.

"Gyakran nagy csapások érték: de a lemondás érzetét szivéhez férni nem engedte. Solis\%or liellett idegen czélokért réreznie; de örök czélja granánt csak saját nagyságát tekintette. A szabad alkotmányt, a nemzeti képriseletet s a szabadságért, az emberi jogokért, azok teljességéért való lelkesülést mindip̣ megörizte“.

,Ebben a szellemben fejlödött ki Mastarországon a miveltebb s vagyonosabb osztályok tagjainál a sájátos magyar miveltség. Az ily míreltségü embert magy ar tiblabironak nerezik".

,El nem merülni az elméletekben: küilsö čélokért fel nem áldozni a\% élet örömeit; önönmascáert becsüini az életet: szeretni a\% embereket; búsulni a multak szenvedésein; kineretni a kétséşbeesóket; nasgy hatatJommal ismerni el a rég\%etet, de föltétlenuil méç annak sem hódolni megr: meglehetös ábráandozás. mérsékelt munkálliodás, idönténti lályats lellesedés, 
erös fajszeretet, az igazsignak eleren érzése: ime a magyar táblabirólélek".

\section{NOMÁD VONÁS.}

A ki pedig annak idejében ezeknek legtipikusabb alakjaihoz elég közel férközhetett, az megbámulhatta izt a disztelenségig menö egrszerüséget is, a melylyel otthonukban beérték, még akkor is, a mikor vagronra, a közélet terén nagy tekintélyre, köztiszteletre tettek szert.

Idönkint elvonulni szölöjük házikójába vayy tanyájulira, ott szemlélödni, ez volt legnagyobb élvezetük a nomád lelkület megnyilatkozása, ennek utolsó és mélyen rejlö maradványa!

Ehhez járult a családi élet tiszta, patriarchális folyása, mely semmiben sem különbözött a közrenden levókétól és a nomád sátoraljakétól.

\section{AZ ÚRI EMBER.}

Hogy a magyarságnak és külön a táblabirói elemnek milyen fogalma rolt az ,,emberséges emberröl“ és az usrifüleskedöröl, ${ }^{1}$ ezt bizonyitja a Szı.Y-család levéltárának következö levele:

Festetics Lajos levele Szily József-hez, Pestmegye alispánjához."

\section{Bizodalmas Nagy jó Uram Sógor Uram és V. Ispány Uram!}

Jankovics úrnak Levelét veszem, melyben értésemme adatott, hogr Mságos Gróff Eö Excellentiájától Fiam Vice Notáriusnak denomináltatott, melynek Denominátiójait nem másinak, hanem I ram

1 V. Ö. VẢMBÉri jellemzésének 3-dik kikezdését.

- Ezért a jellemzö és becses adalékért SziLy KiLMán barátomat köszöntöm! 


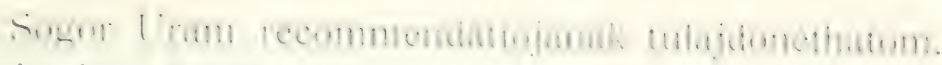

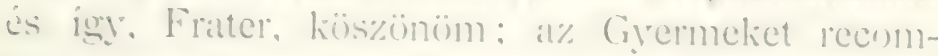
mendálom Gratiádban, kérlek oktasd, legrinkihh a\%

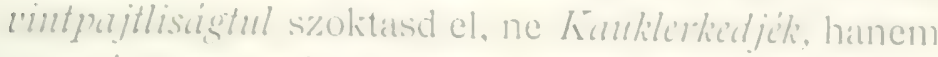

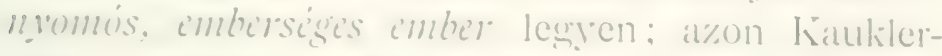

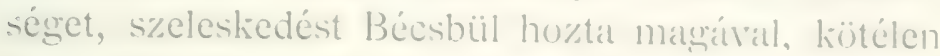

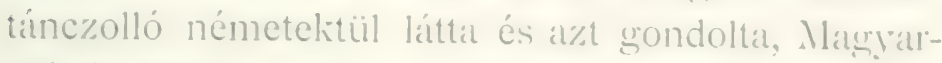
nak is tetszli. Ezzel Húgomal tisztojlocon maşamal Atyaatisággos Gratiájában ajánlott, maladok Sógror Lramnak

Toponár, 15 Maji 178t.

Igaz küteles s\%olgália

\section{Festetics m. p.}

Megjegyzendö, hogy a levélinó Festertes LAuos. ¿ I Ice Notárius ennek fia, AvTal. Lajosnak testrére a srófositott P.í, kinek fia Grörgr, a keszthelyi Georgikon megalapítója. Axtal, kit a levél a bécsi

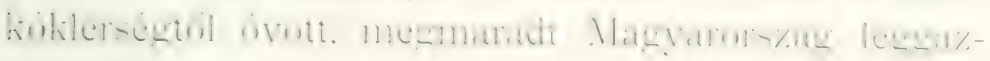
dagabb nemes emberének.

\section{SZÉCHENYI ISTVÁN.}

Erdekes SzEchexil Istrán itélete is a maşrall nemesról. 1

„Hog! a nemesség naģrobb rés\%ének olly šivreható szegénysége, hiányos vagy semmi nevelése s ekiép égrbekiáltó tudatlanságga s jáloatlansáaǵa kiözt. olly törvények alatt, melyek a jendbontóknak liedreznek inkább mint a rendszeretöknek, a közhenyélésnek közzepette, nincs a hazában több baj, több reszély, mint melynek tanui vasgyunk, a\% valóban Isten csodájá, ragy — és e\% hihetöbb, mert csudáli mai világban ninesenek töjbbé napirenden - annak legbizonyosb jele, mily memes iérï, jóindulatú és becsuiletes ember a masyar nemes. 
„Mert ha ez nem volna, már rég magára ruházza más szegénysorsúak hibáit, az álnokságot, esúszásmászást, hizelkedést, fortélyoskodást. És kérdem: valljon nem fáj-e az emberbarátnak szíve - ha nem magyar is - midón ily nemes, jóvérü fajt czélszerü rendszer hijja miatt nagy léptekkel végveštének indúlni lát?:

Az, a ki a magyar társadalmat tanulmányozza és komoly itéletre töreliszik, lehetetlen, hogy szabadulhasson attól az érzéstöl, hogy Széchenyi, korát jellemezre és itéletet mondra fölötte, mintha inkább napjaink hizonyos tássadalnni jelenségreit elörelátta és megítélte volna. Áll ez kivált azokra nézve, a mit az elszegényedéssel kapcsolatban mond.

Az a ,nemes-vérúség“6 nyilván a nomád törzsök ethikájából vette eredetét és szivósságát.

Különben $a z$ is bizonyos, hogy Szécheny az akkori riszonyok között lelküilete egész irányánál és állapotinál fogrà a társadalomnak risszaját nézte és látta élesebben.

\section{KEMÉNY ZSIGMOND.}

E sorban az utolsó, de érték szerint a legelsóbe tartozó jellemzője a magyarnak KenÉNy Zsigmond, kinek éles elméje itt is mélyen szántott. ${ }^{1}$

„Forradalom után“ czímú, 1850-ben megjelent múvében a magyarról jellemrajzot nyújt.

A jellemzés kiindúlása az a szembeszökö ellentét, a mely a magratrágnak $1848 / 4$-iki felhuzdúlásia és a bekövetkezett katonai uralom alatt tanusított nyugodt magaviselete között nyilatkozott meg.

1 Köszönöm Gyula PAL-nak, hogy erre figyelmeztetett. Bizonyos tudákos ,modernség“ úgyis röstelne az arany forrásokhoz visszaszállni. Szálljanak tehát oda a rének. 


\section{A MEGNYUGVÁS OKAI.}

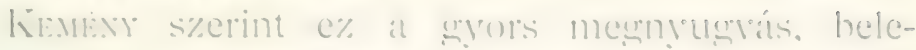

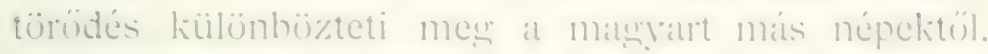
melyelinél at s\%envedélyes felburdúlás utóhatása mén soliain jelentlezili a hosszú, a\% isssecskïrés sth. kipében.

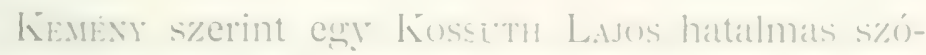
noklata feltüzelhette a nemzetet, reábirhatta a lewnatsobh hösiességre és áldozatlés\%sérre: de nem birtá átalakitani. törekvései szerint megrálto\%tatni: ..mert a matgrar nép gondolliozásmódjában nineseneli megr a\%ok a\% elemek, a melvekböl másutt következetesen, állandólag és kimaradhatatlanul fejlenek ki a nýrugtalansázok, a háborgúsok"..

Es torább:

A magyar népben nincs meg a\% alattomosság. nines meg a fondorkodás ösztöne, a szinlés, a lesbeallás, a bosszú tithos kielégítésének vágỳa.

A magyar föjellemronása a nyiltság.

A magyar aránylag nem bosszúálló.

A magyar a bántalomért nem orrul, hanem a legnagrobb nyiltsággal szerzi megr magranak a\% elégiételt.

A magyar a rérengzéstól nem irtózik: de orozra nem syilkol. Orgrilkost titkos boszúra nem fogad. Orgyilkosnak nyereségráugrból nem szegódik.

Ezek a tulajdonságoh egrüittréve teszik allialmassá arra, hogy gyorsan kijózanodjék.

A magyar nem összeeskülö). Története menetćhen aranylas bámulatosan kerés az ijsszeeskïrés.

A magyar komoly, nyilt homlokú és merés\% s\%ivú nép és éppen azért nem folyamodik olỵ módokho\%. a melyehet a szolgalelliúsér félénhiséue, à s\%envedés- 
bốl folyó erkïlcstelenedés, a bosszú hajlamából folyó alattomosság szokott szülni.

A magyar ember nem hajlik a titkos kicsinálásokra, hanem feltétlen híve a nyilt, ,az isten szabad ege alatt" való végzésnek.

\section{ÖNÁLLÓSÁG.}

Az önkormányzat, a megyei élet megtanította a nemzetet a központi kormány nélkülözésére, az ügyeknek patriarchális módon való intézésére. A régi municzipális rendszer alatt a falu népe sohasem rejtegette gondolatait. Tanakodott, beszélt kivánságairól és aggodalmairól: így tartotta meg nyiltságát és öszinteségét.

Az 1848-iki jobbágyelszabaditás nem szédítette el a felszabadult elemeket. Ezek nem kaptak vérszemre, nem fordultak az urak ellen, nem indúltak foglalásra, hanem örültek a felszabadulásnak és a hol az úr az új rendet megsinylette, az egykori jobbágy segítségére hajlott.

Az önkormányzat kifejlesztette a nép politikai érzékét, a helyzetek gyors áttekintését és az alkalmazkodás ösztönét. Ez fékezte meg a forradalmi hajlamot.

Rendkívül nevezetes az, a mit KeMÉNy a királyság eszméjéról mond.

\section{ROYALIZMUS.}

„A királyság eszméje a magyarnál századok során meggyökeresedett varázshatalom. A - koronás ${ }^{1}$ király iránt a magrara hódoló tisztelettel viseltetik és érte nagy erófeszítésre kész. Így 1849-ben a nép nem vált republikánussá, nem is tudta, meg sem

\footnotetext{
1 Ezt a szót KEMÉNI kihagyta, mi érthetô is, mert könyvét 1850-ben irta.
} 


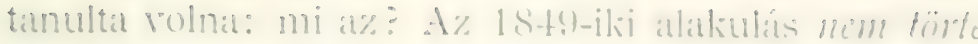

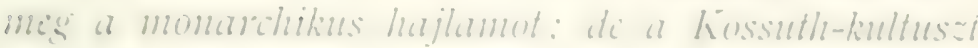

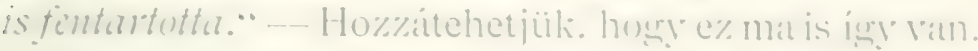

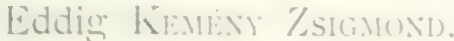

lgen élesen, de kedvesen is, meuriligritja e\%t a sajátságosnak látszó jelenségret ak at bes\%élgetés. a melyet 1887 -ben hosscru Livos-sal Turinban folvtattam s a melynek folramán a magyarág töhetetlen roralizmusa is szóbá herüilt. KossuTn akkor a kiojretkezöt beszélte el nekiem.

Mikor 1St9-ben, a köztársasúg kikiáltásá után. alkalma volt Tiszafüred biráljával beszélni, a biri

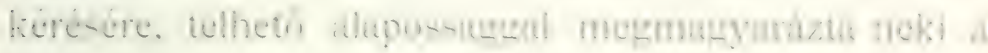
hirályság és a köztársaság hözötti különbséget és a\% utóbbinak üdvös roltát: és ekkor a\%t kérde\%te a birótól, hogy most már mi a véleménye?

- t biró habozás nélkiil teljes nyiltságrgal àt felelte: ..Belátom én most már, uram, hogy csakuglán it höztársaság a jobbik kormányforma; de valakinek esak kell kiralynak lemni!"

Kossuth erre azt kérdezte tölem, hogy neken. ki sokat érintkezem a néppel és bensöbb viszonvlatairal is foglalko\%om, mi a véleményem e jelensér okíra nézve?

A telelet, illetóleg megfejtés nagyon egysserúi volt.

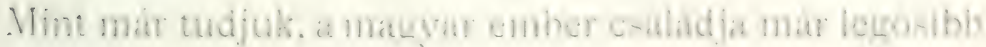
soron is patriarchális szervezetú és az aulitoritáson alapul, melynek azonban jogosnak kell lennie. A családlö = gazda a természet jogánál fogra feje a családnak: ö feleségének ura, neli a család összessérge cselédje. melyet azonban a saolgáual öss\%etéres\%teni nem szabad. A birtrokról és mindenröjl a családfoó rendelkezik: "o büntet és jutalmà, s\%óval föltétlenül rendel- 
kezö fö, a kit csak a család közérdeke és ethikailag a közszokís korlátoz. Hogyha háa birtoka közepében áll, úgy ebben azonos helyzetet lát akár a királyéval is. Innen van, hogy a magyar a királysag intézményét oly könnyen elfogadta, s fogalmat a társidalmi szervezetbe herive: a községet csak biróval, a vármegyét csak föispánnal, az országot csak királylyal bírja elképzelni és csak így fogadja el. Legfelüil áll pedig a legitimitásnak az a formája, mely a születés természetes rendjéból folyik, s a melynek a rátermettség nem föltétele: itt a magyar cmber felfogása szerint minden a juss kérdése, $s$ ha a juss mellett kellő rátermettség is van, úgy ez csak szerencse. Ebben akkor megegyeztünk.

\section{HÁLADATOSSÁG.}

Különben az ellentétesnek látszó kultusz az adott esetben onnan ered, hogy a magyarban nagy mértékben megvan az a ritka erény, hogy igazi, nagy jóltevói iránt mély és tartós hálával viseltetik; különösen akkor, ha a jótétemény a nép emberi méltóságát is orregbitette. Ilyen volt a jobbágyság felszabadítása. Ls vannak a Kossuth-ünnepléseknek közvetetlenül keletkezö, tisztán a néptöl eredö mozzanatai, a melyek mélyen jellemzök, s a néphála legsizebb, legmeghatóbb kifejezései. ${ }^{1}$

\section{A HÉZAG.}

Daczára annak az éles és lehetőleg megokoló

1 Ilyen volt az a jelenet, mely Miskolcz városában a KossurH-szobor leleplezésénél történt. A közrenden levô földmivelő gazdák önszántukból csendben szervezkedtek, koszorút szereztek, mely hegyes végü karóra volt crósítve. A hivatalos programm végeztével a gazdák felvonultak, vezetójük letüzte a koszorút a szobor lábához és oly hálaszózatot mondott Kossuth emlékére, mely a nagy, elökelö közönséget mélyen meghatotta. A formailag is szćp szónoklat KossurH-ot mint a népnek a jobbágyságtól való felszabaditóját, tehát fölemelöjét dicsöitette. 


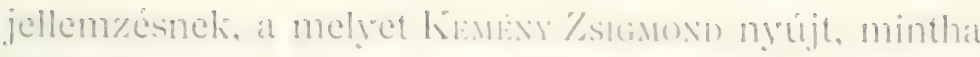
mégis valami hézals. valami homályossily matradnat

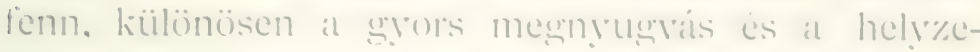
telibe való gyors beleterrödés tekintetéhen. A\% a men-

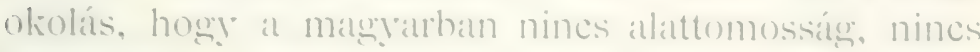

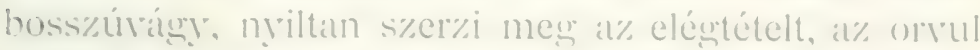
vale támadás nem termés\%ete, nem ïss\%ecskïrö sth. nem elégségeseli annak a erors megnyugrásnak a megoliolásara. Más, hatalmakabh oknak kell fenforogni, hogy a\%t a gyors átrördüilést megérthessüili és természetesnek is találjuk.

A ki jól és alaposan ismeri a mágyar népet, jellemét és észjárását, és tudja bizonyos hatánozott jellegü esetekben köretett mayatartását is, a\% hamal reátjön, hogy a gyors belenyugrás, beletörödés abból a - legkisebb nagyar emberben is éló - tudatból ered, hogy a nemzet tör sökös resze szimszerint nem elég nagy. ,Kevesen vagyunk!“ ,Igen! hal többen

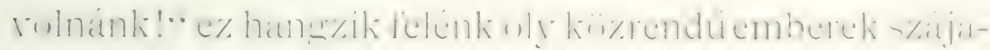
ból is, a kikröl ennyi belátást föl sem tettünk volna. És ezekben tisztán él az az érzet is, hogy elsó sorban a szellemi túlsúly az, a mely a šámbeli hiányt pótolhatja, az uralkodó állást biztosithatja és biztositotta eddig is. Itt tehát nem tulajdonságok hiánya a gyors megnyugvás oka, hanem a helyzetból folyó bölcseség, mint a nép malgasabb értelmének eredménye. 


\section{A JELLEM KÉPE.}

A magyarság legrilágosabban megutartotta a középazsiat lovas, egróltalában állattenyésztö, pásztorkodó. sátoros nomádsálg jellegét. Nomád szerrezeténel sok nyoma a pásztorkodásban, halaványabban a halászat. leghalaványabban a népies vadátszat terén maradt megg a legújabb korig is.

Családjáhan és foglalkozási kereteiben szervezete a természet rendjén, a koron és tapasztaltságon alapuló patriarchalizmus volt

Közéletét a törzsnek, mint népegyetemnek, közakarata vezette.

A családban a tekintély föltétlenül a férfit illette; a nó meg volt becsülve; de nem ura mellett, hanem utána következett; a család kor szerint az asszony után sorakozott; a fiú elóljárt.

A patriarchális szervezetbe be volt vonva a fajilag azonos cseléd is, mely az idegen szolgánal elébe rágott.

Megjelenése szerint a magyarság méltóságos; mağariselete szerint komoly : hallgatagságra hajló; a fecsegó) és ugrándozó mascariseletet, mint férfihez nem illöt tekinti.

A magyar föltétlenül vendégszerető és tisztességtudó.

Föllépése nỵilt és bátor, bámily földi nagrságenal szemben is, a mi nagy és erớs önér\%etében gyökerezil.

Az önérzet sokszorosan jelentkezö, történelmi és társadalmi fejlödése révén s\%er\%ett tulságúhan şrölere\%nek a magrarság legröbh hibái is, mint legkirivohbak: a hivalkodás, meg nem féró természet, önhitt-

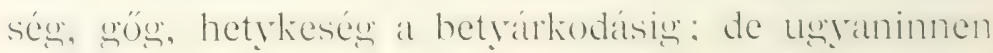




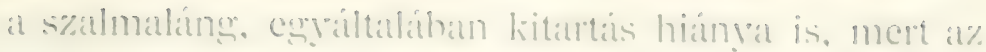

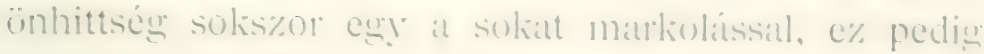
at keveset s\%oritaissal. mely criponguisho\% re\%et.

Sohasem alazatoskodó.

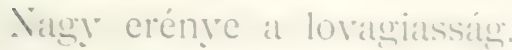

A magrar megtartjat adott szavait.

A magrar nem kivátnesi, nem könvörơös.

'Támadásar nyilt, bátor, sohatsem alattomos; nem gyilliol orozvar, nem forral bosszút. Sen lop, hanem elveszi azt, a mit akial.

A magrar nem titkolódzó, tehát nem összeeskiuroü.

A magyar szavajárása velós, soliszor élies: szuiletett szónok.

Szelleme szerint kiválóan eszes. elmés. kiölöoi hajlamú. Szereti a hasonlatot, a parabolát, a dolgoknak önmagával való viszonýtását.

A magyar a folytonos, iparkodó munkának nem

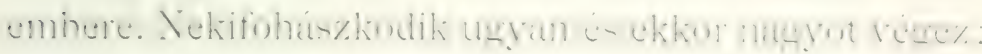
de ezután nagyokat pihen és álmodozik.

Ezért a magyar nem is hajlik a folytonos munkítval szerzö, alkotó iparra és kereskedésre; hà rákényszerült: menekülni iparkodik az anyaföldhöz, a halas vizhez, a hol szemlélödö, sokszor a restségrig éró hajlamát kielégítheti.

A magyar nem ment az urashodás hajlamától: szeret „mutatni“. Köztéren szereti a fényt, házában sohszor a sivárságig menó egyszerüséget; de élés-

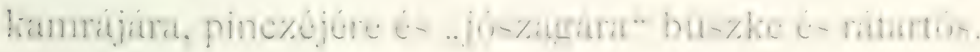

A magrar ember nem hagyja jussát, véleményéhez makacsul ragaszhodik: a világ legszivósabb, meg nem syözhetö pörlekedöje és örökös pártoskodója.

A magyar kijzel áll a természethe\%, jöanon forgat fel a jelenségelet, tis\%tán tudja saját réres voltát: 
semmin sem csodalkozik, mindent jól megnéz és elsö gondolata: a dolog nyitja.

Esze élességével, józan gondolkozásával sokszor oly dolghokrol mond biztosan találó ítéletet, a melyelitól alapjában véve távol áll. ${ }^{1}$

A magyar helyzetének sajátos és kényes voltát jól ismeri és helyesen fogja fel: tudja, hogy mint nemzet s\%amszerint nem nagy, hogy a számbeli hianyt eszességšel és nemzeti sajátossígainak lentartásálval, kifejtésével lehet legbiztosabban pótolni. Ezért hatalommal szemben is türelmes, helátásból és bölcseséguböl meşférö; szabadságát megosztó. De jogaira féltélieny, azoknak védelmében éber és eszesen kitartó.

1 Az utóbbiakra nézve páratlan a magyarságnak kiállításokon való magaviselete. A fény nem kápráztatja, az neki ,hiábavalóság“; de mindaz, a minek hasznát vehetné, felkölti és teljesen leköti figyelmét; rendkiviüli haszonnal nézi. A múvészettel szemben sokszor bámulatos biztossággal itél. Igy a bizony gyönge ezredéves felvonulás körképével szemben a nagy családdal bejött vidéki kékbeli ember így nyilatkozott: „No mán, a ki ezt csinátta, ee nem tanáta." A plasztikus Bem-Petöfi körképre ellenben azt monda: „De mán, a ki ezt csinátta, az eetanáta".

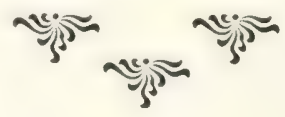




\section{BEYCR() SZO}

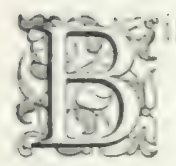

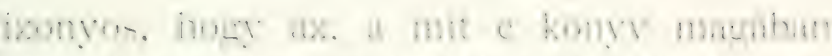

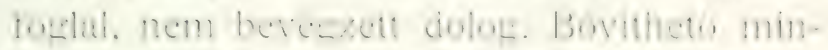

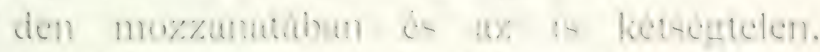

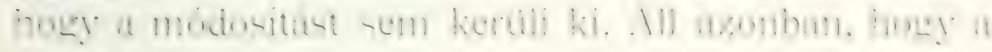
magrar nemzet arczulatának ebben a formában és keretben való bemutatása inkább illet volna a\% 1900-iki századforduló nagy allämáho\%, mint illett az, a mely az anthropologiának világkiongresszusán tényleg benutattatott.

És ez a munka, a nélküil, hog̣ maga ellen a s\%erény"telenség rádját kihírná, talán megrörvetelheti annak a\% elismerését, hogy a magyarság nagy és bonyolult problémájának megfejtéséhez új s\%empontoklál járult, a melreket kicsibe renni nem lehet, mert valóban reális alapon nyugosznak, innen indulnak a feladat megoldásà felé.

Jellemzö, mélyértelmü és sokat mondó szó al lisirbérI-é, a mikor az összehasonlítás útján, meg̣érezre a hiányohat, azt mondja, hosy sok ismeretlen tényt lehetne földeriteni, hogyha memesuk a mugjur. hanem a rokon nepek szokisail is alaposan ismemo"k.

És valóban, ha aról ran szó, houg̃ a mkon népek jellemzö és jellemalakitó szokítsait és ebböl kifolyólagr lelkületük, lényüik kialahulását a magryaral ijss\%ehasonlitsuk, mál az elsö lépésnél is mergakiadunk. 
A nyelvészettel igen sokat és lényegeset lehet clérni: de mindent nem. A szellem nyilvánulásainak bizonyos rendü méltatásával — Folklore — hasonlóképen.

De vannak az élet és életmód irányzataiban igen jellemzó, mélyreható sajátságok mint e könyrben a nomád lelkület megnyilatkozásai a melyeknek alapos ismerete és számbarétele nélkül, az adott népröl megalkotott kép csonka marad, a melyeket sem elhanyagolni, sem mellözni nem szabad, mert az anthropologiának igren lényeges tartozéliai; már azért is, mert reáhatnak az arczulatra, söt a szervezetre, igy tulajdonképen bizonyos riszonylatokban psychikai és ethikai éló értékelöi annak, a mit a mérö somato-anthropologia mint sajátost megállapít.

Es a hányan csak a magyarság problémájának megoldásával foglalkozunk, kénytelenek ragyunk köteles szerénységgel bevallani, hogy közrendünket nem ismerjük intim élete, szokásai, lényének kialakulása szerint kellö alapossággal. Ez igen nagy hiány, a melyet pótolni kell. Kiknek?

Nekünk öregeknek már nem lehet erre vállalkoznunk.

A kik elég közel allunk a feladathoz és néha biráló szót is ejtünk, nekünk mindig az rolt az álláspontunk. hogy a magrarság kérdésének alapos, ragy bár elfogadható megoldásának alapföltétele, a magrararsignak itt, a hol él, alapos megismerése, bensöbb riszony̌ali szerint is alapos méltatása.

Mert valójában azok, a kik ez alapföltétel nélkül ¿zsia népóczeánjára bocsátották kutatásuk hajoját, derék. grazdagon felszerelt járómürel ereszliedtek a néps\%oliásoli tengerére; amonban egy lényegres kellék hijan, mely 
nélkül at lecrobb hajo is bénat, mert biztos iranyt nem vehet, igy čélt sem érhet. Hianyott pedig a\% a\% ér\%é-

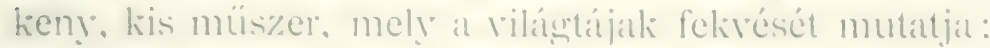
"1: irinutil.

Már pedig ha a feladat ar: en adott nemzet nyomat err tálolesö vilagrészben, népek és szokásalik tarka reṣlö̈letében felkeresni, akkor a\% iránytü annak a nemzetnek alapos ismerete, melynek nyomdokat keressüik.

Elismerem, hogy lehet e fölött vitatkozni; lehet a dolgot úgy is felállitani, hogy a fö az: sok anyagot

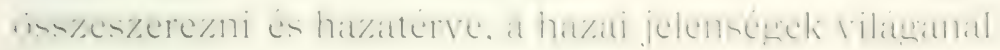
hiválogatni azt, a mi rokon. Lemondok arról, hogy a rak ty’úkról szóló népszót ez ötletböl megrokoljam.

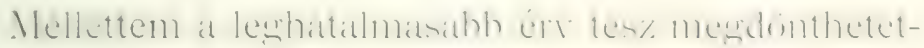
len tanuságot, és ez az, hogy a nemzet legjellemzöbb sajátságai szerint is rohanva alakul at.

És igy lejárt az ideje annak, hogy a módszer fölött tusakodjunk, itt a megmentésröl van szó, ha nem hésö - mert ez is meglehet.

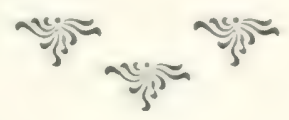



III.

FÜGGELEK. 



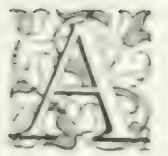

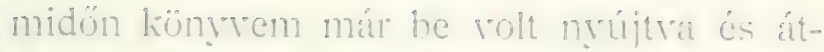
ment a birálaton is, alkhor jelent megr Truos Áros-tól ily czimüi munka: ...Magray alkotmány és jogtörténet. tehintettel at nyugoti állanoli jogrejlödésére. Budapest 1902.” Elöszarar 1902. szeptemberben kelt.

Ez a minden tekintetben jelentös és kivailó mü. errész terjedelmében es minden részében a\% irodalmi furrások leggondosabb fölhasználásával épüilt fel és minden köretkeztetésében, a mely az irodalmi források keretén túlya is vezet, rendliviul ovatos, mert tiszteletben tartjat a megoliolhatis minden liovetelménveit.

Minthogy pedig Trmos Áros kïnve a masyar aikotmányt és jogtörténetet lehetöler a nemzet öskorátoil kezdre szervesen igyehezik levezetni, megragadvat minden erres, még a leghezdetlegresebb mozzanatot is. a melyet az alkotmány és jog csirájának lehetünk, nagyon természetes. hosy könyve a\% én könyremmel tárgy és viszony szerint sokszorosan szembeherül. különösen abban, a mi az ösi s\%ervezetehre vonathozik. a mit ó mint történetiró a mara es\%hijzeivel, én mint ethnológus a masaméival állapit és állapitok mesg. Ö könyrének .1. Korszakt. Az ösi

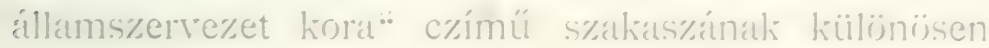


II-ik fejezetében, melynek czíme: „Az ösi államszervezet és birtokrend", én leginkább abban a részben, a melyben a magyar nép jellemét bizonyos élö, ethnologiai elemekböl levezetni és megszerkeszteni iparkodom.

Lássuk most már Timos könyvének illetö, igen tömören írott részének - mindössze 1-75 oldal egészen tömör kivonatát, avval a megjegyzéssel, høgy az elözményeket - hun-avar korszakot - mellózve. azt adom, a mi már világosan a magyarokra vonatkozik. Tixon eszmemenete, illetöleg sorrendje így alakul:

A magyarok eredete ismeretlen.

Az őshaza bizonytalan. Megbízható adatok csak Lebediában való tartózkodásukról vannak.

Bizonyos az, hogy turáni fajhoz tartoznak; de nehéz eldönteni, vajjon a magyarok az urali - finnugor -.- vagy altaji -.. török-tatár - ágazathoz sorolandók-e?

Nyely szerint a magyarok közelebb állanak az urali - finn-ugor - mint az altaji - török-tatár - ágazathoz; de ez nem dönt, mert lehet, hogy a török-tatár eredet jelleme a tartós finn-ugor érintkezés behatása alatt nyelvileg elenyészett.

Konstantinosz a magyarokat még turkoknak nevezi.

Etelközt a magyarság 889-ben foglalta el és itt következett be törzseinek egyesülése.

Az állandó haza elfoglalására, melyet a magyarság kalandozásaiból már ismer, 895-ben már egységes vezérlet, ÁRPÁD alatt indul.

Az oshazában, valamint Lebediában a magyar nép a patriarchalizmus alapján kifejlödött törzsszervezet korát éli. Ennélfogva a törzs a magyarság közélctének elsö formája. 


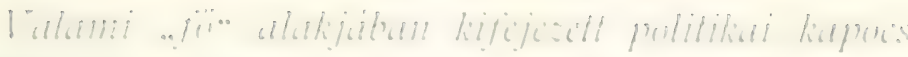

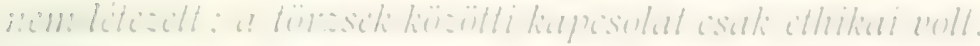

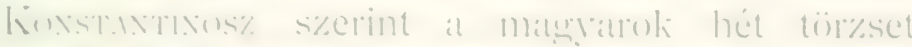

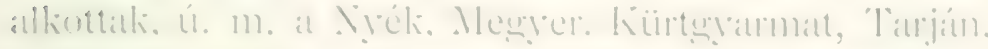

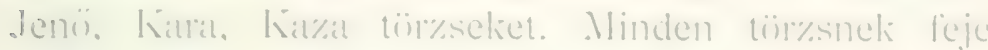

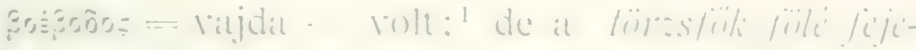

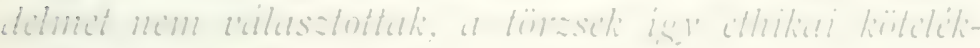

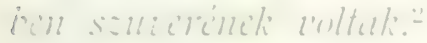

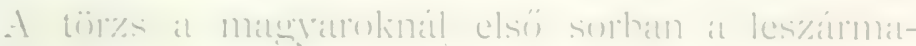

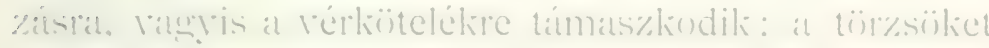

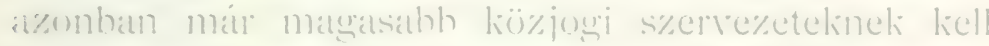
tekintenünk, melvelét al vérhëtelélien túl at hoss\%at:

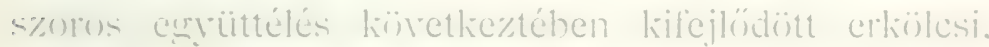
szohásheli, müveltségi és vallási kïzösség fü\% öss\%e.

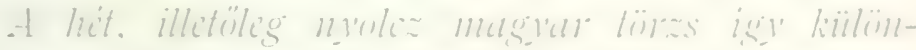

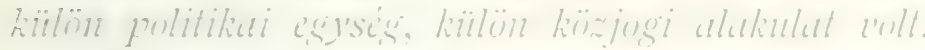

At tö\%set tehát nem s\%abad egrszeruí nemzetségneli

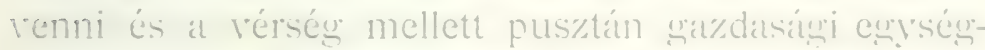
nek telinteni - mál azért sem. melt at tïr\%s mint magasabb alakulat, nem\%etségek foglalatjat.

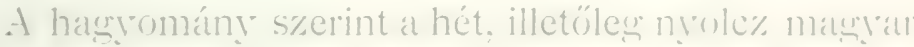
tijms s\%álznyolez nemzetségre os\%lott. A nemzetsém

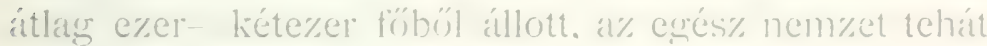
biizepes számítással 1 fo(0)(1)() före rúshatutt.

I A tiorzsfö mayyar elnevezése. Thuo: szerint. ing litszili elveszett

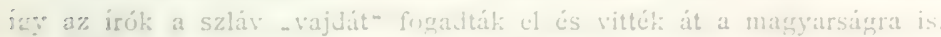

= Traros adja a lieleti imok - Ibn Roszteh, Gurdezi és lil-Jekri - illiasait is, a melyel szerint a magrarol: ïsi szervezete monarchilas volt volnat

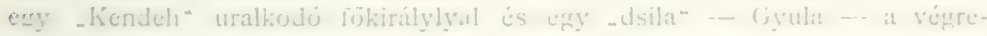

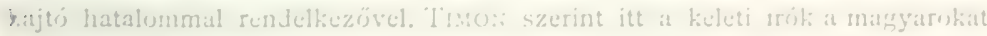
a kazarolkal tévesztik ïssze, liki cwel a szervezcttel csakthyan birtak. A\%

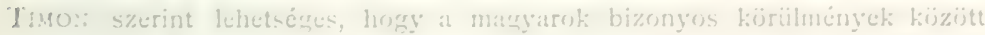
r. o. hiború esetére viduszthattal: fujet "hendeh" név alatt és fötisztet

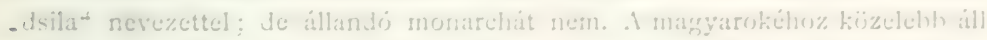
a Volga - Itil - melleti belgarok szervezete - : tirzs - és besce-

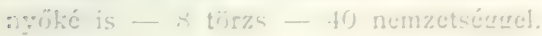


A törzsfö nem volt uralkodó, szuverén, hanem a törzsnek inkáhb csak elsö tisztviselöje, háborúban, héliében kormányzója, a ki hatalmát a tör sgyoüléstël megbízásként nyerte.

A nemzetségek nemzetségi fönököket -. valószimíleg ,hadnagyokat" — választottak, kik kivált a gazdasági ïgyeket intézték s valószinilleg örökösödésen is alapuló válasatásból keriiltek ki.

Közös támadás, veszedelem vagy nagyobb mozgalom - költözködés — esetében a törzsek egyeteme a tïrsfönökijk kïzüil a legkitünöbbet förezérüil válasz-

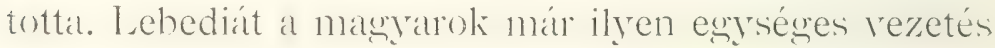
alatt hagyták el.

A fövezérség azonban csak az adott egy es̀etre szólt.

Nyilvánvaló, hogy az idók folyamán történt soks\%oros, förvezérség alatt való egyesülés vezetett a fejedelemséghez és utóbh a királysághoz; de mindenkoron az örökösödésen is alapuló választás korlátjával.

A honalapitás a nemzet közakarata alapján történt.

Az elfoglalt területen nem lévén semmi szervezett elem, a magyarok egységes nemzeti jogrendjükbe helefoglaltak a területen talált syoülerészséget, három kategóriába osztva azt:

1. A föltétlenül csatlakozó elemek teljes egyenjogúsignt nyerve, vagyonukhan is szabadon maradtak.

3. A semlegesen viselkedők nem nyertek egyenjogúságot, de szabadok és vagyonban maradtak.

3. A fegyveres kézzel ellentállók rabszolgákká váltak. Ez volt a jobbágyság csirája.

Az államforma ekkor demokratikus volt, minthogr a fö, döntö hatalom nem az egyest, hanem az ös\%szességet illette. 


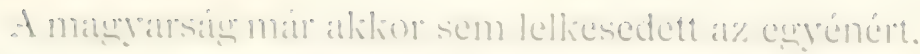

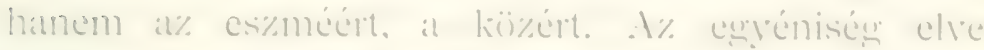
sohatsem emelliedett at allamisily, at matginjog sohat a kïijon rölé.

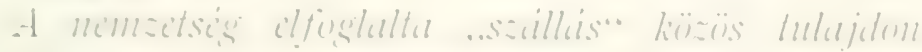

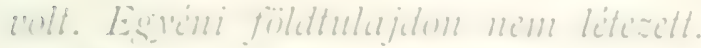

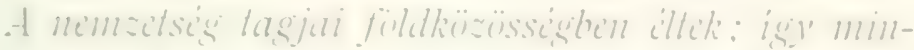

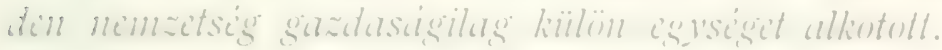

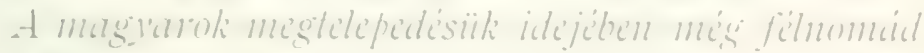
ilitil iltik.

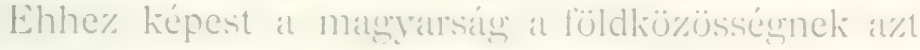

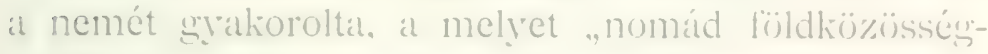
nek" nevezüink, a midön a méğ kezdetleụes földmivelés és mál virátyzó állattenyésztés a\% irrísi hatálrokon folyrást le'lyet is'rél.

A földmivelés erósödésérel halad a megtelepüilés: a családok elküilönülnek, a kïzös táborok oszlado\%nak. A mai tanyák képére küiön, állandó háztartásoli keletheznek s elöáll al családi házhözösség, végre a\% egréni birtok mint magántulạjon.

De az ország területének jelentékeny rés\%e a nemzetsérg szerint való földosztásba nem ronatott belé. még pedig természeti okoknál fognă. Ezek a részek a tör\%s küiön tulajdonát alkották torábbra is: meumaradtak az egréni tulajdon mellett is tovább folyé nomád és félnomád gazdasási élet, mint: halášal. vadás\%at és baromentenyésztés üzésére. Itt tehát elsioj sorban a vizek, nádasok, rétségek és legelök alliottak továbbrat is a törzs liözojs vátgyonat.

A törzs kiozijs tulajdona a monatrehikus elv grö̌zelmével változott nemzeti vaş állami tulajdonná, a midön a király ráteszi a kezét és mesallostjat al vármeryét. Eddig Trum Áros. 


\section{FGVETHTES.}

A történeti és ethnologiai felfogás ezek szerint a következökben egyezik az ósi állapotra nézve.

A nomádság jellegében, ebben:

a) A patriarchalizmusban.

b) A törzsszervezetben.

c) A törzsszervezet szuverénitásában.

d) A nemzetségi szervezetben:

s.) Az egy családnevú falvakban.

\$) A "sorokban“.

v) A "hadakban".

(') t törzs és nemzetség földközösségében:

1. A vándorpásztor életben.

2. A vándorhalász életben.

A mi azonban nyomban szembeszökik és mondhatatlanul fontos, ez az, hogy a most folyó élet

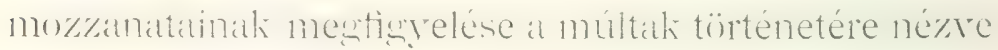
nemcsak kiegészitö, hanem mélyritő hatással lehet és van is. Itt és így ölelkezik az emberismeret szolgálatában az anthropologia, ethnologia és a história, és ez irja elö az utat, a melyet a "magyar" probléma megoldásában a jövóben követnünk kell.

Budapest, 1902 október hará.

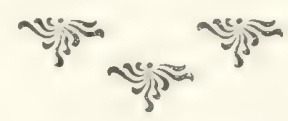




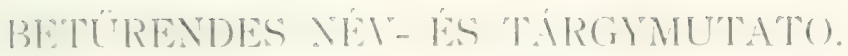

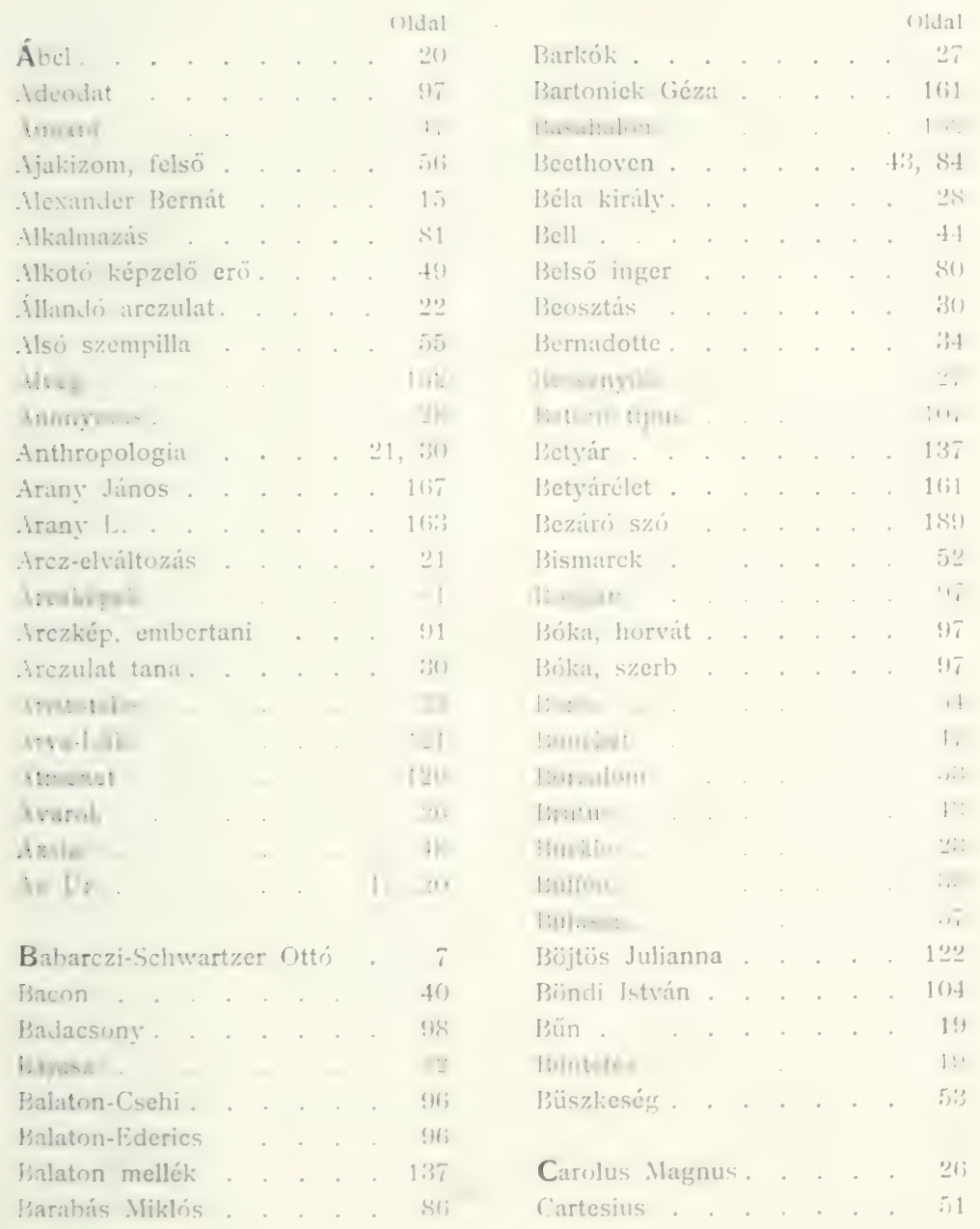




\begin{tabular}{|c|c|c|}
\hline Chodowiecki & & \\
\hline Cogito & & \\
\hline Cromwell . & . & \\
\hline Csallóközi észjárás & . & \\
\hline Csángók . & & \\
\hline Csimbók. & & \\
\hline Csomós bokra & & \\
\hline Csók . . & & \\
\hline Csukcsok . & & \\
\hline Csupor uram. & & \\
\hline
\end{tabular}

Dal . . . . . . 167

Dankházi . . . . . 97

Darwin . . . . . . 38

Deák Ferencz . . . . 62, 86

Debreczen . . . . . 152

Derby, Lord . . . . . (32, $86^{\circ}$

Dobos Sándor . . . . $15: 3$

Dobó uram . . . . . 137

Duchenne . . . . . 40

Diih . . . . . . . .33

Édeshésség . . . . . $7 \pm$

Egyenes orr . . . . . (i.)

Egyeztetés . . . . . . ㄱ(11)

Egyiptomi . . . . . . $4 i$

Egyiptomiak . . . . . 33

Éles elme. . . . . 1ti.j

Ellenszenv. . . . . . . . $: 3$

Elragadtatás . . . . . (5)

Elváltozott $\operatorname{arcz}$. . . . . .1

Emberismeret . . . . 201, 2:3

Endréd falı. . . . ؛ ؛i

Eötvös József . . . . 14t

Eötvös Károly . . 1 1,j, $156 i$

Eredet . . . . . 172

Erzsébet királyné . . . 17i3

Eszesség . . . . . 1711

Eszkimók . . . . . . . . . .

Ethnos. . . . . . . 2

Európai . . . . . + th

Expanziv mimika . . . 4 .

Fájdalom

Faji egység i)

27
Faji kérdés

Fáró uram . . . . . . 125

Fejér György . . . . . 105

Féktelen düh . . . . . . . . ?

Feladat . . . . . 91

Félelem . . . . . . . . . .

Felháborodás . . . . . 5:;

Felorditás . . . . . 5ij

Felsô szempilla. . . . . 55

Feltétel . . . . . . . . . .

Felvég . . . . . 1.)

Fennhéjázás . . . . . 5:3

Fény . . . . 17:2

Ferencz császár. . . . . i;

Ferenczy Ida. . . . . . 15i3

Festetics Antal . . . . 17!,

Festetics György . . . . 179

Festetics Lajos . . . . 178

Festetics Pál . . . . . 179

Figyelem . . . . . . 53,7

Figyelés . . . . . . it

Finn-ugor törzs . . . . . 1(u!

Fitiszmadár . . . . . 40

Fitymálás . . . . . . Tii

Fiziognomiai elváltozás . . …

Fiziognomika . . . . . 311

Fogvicsoritás . . . . . . . .;

Folklore . . . . 3 31

Földirati felosztás . . . 4 i

Főjegy . . . . . . . 1:3!!

Fölvétel . . . . . . 41

Förend . . . . . . . 14

Franczia . . . . . 4

Fränke . . . . . . fi

Franklin . . . . 43. 11

Frigyes II . . . . . 4:3

Fuesslin . . . . . th

Függelék . . . . . . 1!14

Fütyülés . . . . . . . . :

Füző. . . . . . 1 . . 1 .

Gaál Gaston. . . . . .

Galambos uram . . . . 12,

Gall . . . . . . 4

Gazdasíg . . . . 11. 


\begin{tabular}{|c|c|c|c|}
\hline & (), 1 al & & (1) \\
\hline Gierminok. . . & $\ddot{2}+i$ & Hěrag & 1.81 \\
\hline iesta Hungtrorum. & 28 & Hibia. & 101 \\
\hline Giblion . & 17 & Ilivlité tulajgonsigg. & $17: 2$ \\
\hline 1. tile. & (1.. $43, \quad 52,8,3$ & Homlnkizom & in \\
\hline Golinrili. & $4 i$ & Homerosz. & (iii) \\
\hline (iond. & $5 i 3$ & Homo delinquens & 416 \\
\hline (ionos 57800$)$ & $+1 i$ & Honfoglalis & $11 i$ \\
\hline Givise & 12.4 & Itortohigy . & $1: 36$ \\
\hline (iiidrieske. & lii & Heittentetta & 48 \\
\hline Girrige & is & Hughes. &.$i$ \\
\hline (Giirineseir. & 17 & Hunfalyy diagnózisa & la! \\
\hline Sirtininlet & 38 & Hunfally l'ál . & $\because$ \\
\hline Cirimasz & 41 & Hungar. & 1. \\
\hline Guarima & 17 & Humnok. & $\because$, \\
\hline Givérin & $: 36$ & Hunyoritis szem . & $11 \cdots$ \\
\hline (;ulaizom & $i k i$ & Iluselike & it \\
\hline liúny & $\therefore 3$ & Hlisos orr & $1 \cdots$ \\
\hline liyanakias. & $\therefore: 3$ & & \\
\hline livillios. & 11. & Ijodelem, nagy . & . \\
\hline Gy̆ulai P. & $1(i: 3,180$ & l:" & $1:$ \\
\hline (ivüleviszseig . & $111 i$ & Irimy & $\therefore 1$ \\
\hline & & Iranyi & 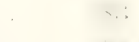 \\
\hline Hathichtsnase. & 1113 & Irigység & $\ldots$ \\
\hline Hall. hatalom. & $11 s$ & Iszonyat . & $\cdots$ \\
\hline Had, nemzetség. & 119 & & \\
\hline Hahota. . & $\pi$ & Jacovone & 1. \\
\hline Hajviselet . & 120 & Járomizom, lis & $\cdot x$ \\
\hline Hajviselet, régi & $121)$ & Jíromizom, nagy & wi \\
\hline Hirjzat . . . . & $8 \overline{5}$ & Iászok . & $\because 7$ \\
\hline Hajzat, rronosztevölić & $8 ! 3$ & Jean-Paul & 43,83 \\
\hline ¡Háladatosságr. & 184 & Jehova. & 23 \\
\hline Haliśs. & 15.4 & lellem & $: 41$ \\
\hline Haláz üzenet & $1 \ldots$ & Jellem iskolája & $1.51 ;$ \\
\hline Harag & $.3 \%, 7 !$ & Jellem képe . & $i s i$ \\
\hline Haramia tipus & $16(6 \mathrm{i}$ & Jemtland & 1112 \\
\hline Harless. & : : & Jóakarat & 57 \\
\hline ¡iromszögrizon & $j i$ & Johbigy . . . & ' '.. I: \\
\hline Hasonlat & $16 ;$ & Jobbágy Jüzsef . & 107 \\
\hline Hazaszeretet & 172 & Jobbágyság & (1) \\
\hline Heckel. & 97 & Jijtment . & $1: 1$ \\
\hline Héjja feje. & (ii) & Józansig & 125 \\
\hline Héjjaorr & $1 i 5$ & Juno & (3:3) \\
\hline Hetieli & $\$ 17$ & & \\
\hline Herke Pál & $111 ;$ & Kacsioh J'ál & $\therefore \quad 121$ \\
\hline Hervadis & $1: 2.1$ & Kaczagris & (ii) \\
\hline
\end{tabular}


Oldal

Oldal

Kain. . . . . 20, 21

Lacenaire . . . . . 47

Kalap és turbán. . . . 154

Lakoon

$43,8: 3$

Kalvin

Lapp

Kankó József . . . . . . . 99

Laufenauer Károly

Kiatilin II. . . . . . 4:3

Lavater . . . . . . . : :

Katulbach _ . (3:3)

Lizár István . . . . . . : : . . .

Kedvetlenség. . . . . . 80

Lélek tükre

Ǩegyetlenség . . . . . . 5ỉ

Lenhossék .

Kolemen kanász .

132

Kemény Zsigmond

Leonardo da Vinci

Keserüség.

Lichtenberg

Kifejtés-jellem

Locke

43,83

Kiliti falu

143

Lombroso

Kïindulás

Lombroso tipus

Kisérlet.

Lovas nomád.

Kiválasztás

Klats

Kléber . . . . 34, 43, \$1

Lud folt

Kocsis Antal

Komáromi .

I,uther

Komáromi Imre . . . . 1117

Kumblysitg.

Macaulay

Konczentrikus mimika .

Köny

Kónyi

Köpés

Körizom, szájé . . . . . jli

Körizon, szemé . . . . . 51;

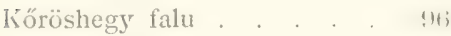

Körösi József . . . . . :;:

Körszakíll . . . . . . 12:;

Kossuth és a biró . . . . $18: \%$

Kossuth-szakáll

lioszkol Jenó .

Koyács János

Közrend

Lriza J.

Külsó inger

Kultura .

Kunok

Kun uram .

Kupa vezér

Macaulay-Trevelyan .

Maczelka uram

Magyar lélek

Magyarság .

Magyar tipusok

Mai magyarok

Majlát János .

Majlátné

Majlát-törzs

Makfalvay Géza.

Malagutti

Mantegazza

ti. 47

Mányoki

Maori . . . . 47

Maráczi József . . . . 10ti

Maradványok . . . . . 11!

Matejkó . . . . 177

Matyikó . . . . . 97

Meghatározás . . . . 2 29!

Kintató gondolkozás . . I!)

Meglepetés.

Mély iilés. 


\begin{tabular}{|c|c|c|c|}
\hline & (man) & & ()ial \\
\hline Mestnyuswis oketi & 181 & $\mathbf{O}$ kien & +4 \\
\hline Megriadili & $\because$ & ()ill & $:$ \\
\hline Menictio & 11. & ():is: & 4 \\
\hline Meitzen & 146 & (i)nillósign & ; ' \\
\hline Menyecostie. & bit & ïnérzet. & int. \\
\hline Meresztes & & (insirzet, magyau & "' \\
\hline Milnalkmvies & ", & ()rilit. & (3). \\
\hline Milicu & 1. & (irlit. & 11. \\
\hline Wimikit & 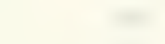 & (i)rim & $\cdots$ \\
\hline Mimikai dviltozás & 21 & (1r, usztily"uzis & 11: : \\
\hline Mimilaij kïzpont & in & ()rezimpil-izom & isti \\
\hline Mermmsen & $\therefore$ & (i)syntiles & 1.21 \\
\hline Mundiksok. & lliti & (1):iunder & $: ;: 3$ \\
\hline Mombiank cle. & $1(i)$. & (1) si szervezet & $11 ! 1$ \\
\hline Mureatu. & . & () ss\%egezis & $8(1)$ \\
\hline Mirocz. & $\therefore \quad 135$ & (i)swehasonlitis & $168,16 i !$ \\
\hline Mescoly. & $\mathrm{ing}$ (ii & ()svald. & $! \pi$ \\
\hline Mlosilyon izom & . . . iti & (i)stiin. & $1 !)$ \\
\hline Mizsed & . $11=$ & & \\
\hline Miiller. Johinnes & 4:3, 10.2, 8.2 & Pikilis\% . & i: \\
\hline Müverzet & $111 i$ & $\begin{array}{l}\text { P'allí-izonir } \\
\text { Palciczok }\end{array}$ & $\because$ \\
\hline Nagy Frigyes & sis & f'ampat & 1. \\
\hline Sagy finum & 1114 & P'aptagaij-orr & $\because$ \\
\hline Napoleon & +43. S1 & l'árej lstrin & ine \\
\hline Néger & ti & P'iszter . & 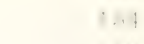 \\
\hline Sima nyely & . 43 & l'isztor és kirúlynú. & :in.. \\
\hline Ninet & $4 x, 47$ & P'isytorkodis hirtokos & 1111 \\
\hline Vemet Jizsef & $! ! !$ & Patagon. & : \\
\hline Simet l'éter & 1114 & P'ati-Nagyoli & 1. \\
\hline Nenzetsig & $117.11 !$ & P'atriarchalizmus & $1 \%$ \\
\hline Nepiralat. & $1: 3$ & P'auler Gigula. & $11 \quad 115$ \\
\hline Nepirutalom & $17+4$ & Pentateuch. & \\
\hline Ciplailté & $11 ; \bar{i}$ & Piderit & 1, , , : \\
\hline Vern. & $4: ;$ & P'isze-ort & 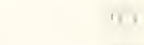 \\
\hline Nercetís & $2: 3,198$ & l'ortugal & y \\
\hline Vevetén fuhoti & lii & l'syche. & \\
\hline Xise. & 23 & & \\
\hline Xisi stupsegr & $1: 3: ;$ & Ric\% uram & 16 \\
\hline Xormait rend & $1+i l i$ & Ranke & $i$. \\
\hline Conmidatie. & 1.45 & kansak\% fierenc\%. & $11 \%$ \\
\hline Sombl ventis. & 17 & Reinhated asszony & it \\
\hline Siordenatiolla. & 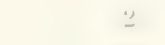 & Rendiseif & $\cdots$ \\
\hline Sircicin & $\overline{-}$ & $\begin{array}{l}\text { Ré-homirom } \\
\text { Richelieu }\end{array}$ & 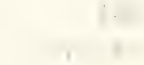 \\
\hline
\end{tabular}




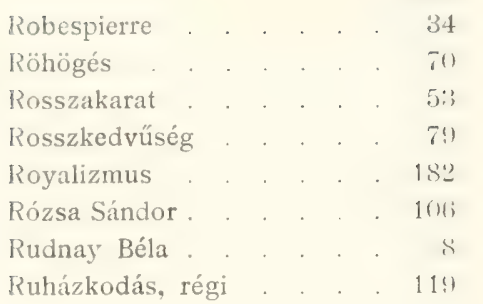

Sas feje . . . . (if

Sasorr . . . . . (it

Sitorfa . . . . . 14;

Satrál . . . . . 8

Schack . . . . . i,t

Schwab. . . . . 3:;

Scott . . . . . 8.3

Sebestyén . . . . 8

Sebestyének . . . . 1:35)

Sémita orr. . . . (i.)

Shakespeare . . . . . \$1

Sirás . . . . . . 5, $\overline{7}, 7 \pm$

Siró arcz. . . . . . . 7:3

Sírva vígadás. . . . . . 162

Sóma . . . . . . 19

Sor . . . . . . 114

Sorok . . . . . . 14!

Spanyol . . . . . . 48

Specht . . . . . 36, 89

Spener . . . . . . . . 8른

Sutter. . . . . 47

Svajczi. . . . . 48

Symbolika . . . . . : 38

Syriai . . . . . 48

Szabad föld . . . . . 14ti

Szájtátás . . . . . . . 5:3

Szakadatlan sor . . . . 113

Szakáll . . . . . . \$2

Szalay, öreg legény . . . 127

Szám . . . . . 17t

Számadó . . . . . 1336

Szárszó falu . . . . . 96

Széchenyi István . . . . 179)

Szeged . . . . 1:37

Szćkelyek . . . . . 27

Széles József . . . . . 12t ()laal

Szem . . . . . . . . 6 (i1

Szem, élénk . . . . (i)

Szem, fátyolozott . . . . til

Szem, kalandozó . . . . (i:;

Szemkörizom . . . . . . $5 \overline{5}$

Szemlélődés . . . . . 15!

Szem, lusta . . . . . . (il

Szem, meredező . . . . . $\{;: ;$

Szem, nyugtalan. . . . .

Szemöldökizom . . . . . $5 t^{2}$

Szem, osztályozás . . . (i)

Szempillák . . . . . . 5.)

Szem, szelid . . . . . (i巳

Szem, szilárd. . . . . (i2

Szem viselkedése . . . . 44

Szentey . . . . . . 1:37

Szilber . . . . . . . 97

Szily József . . . . . . 178

Szily Kálmán. . . . . 178

Szita András . . . . $101 i$

Szittya . . . . . . $4 \mathrm{H}$

Szittyák . . . . . . :3:;

Sziver . . . . . 97

Szláv . . . . . 45

Szobrok . . . . . 81

Szomorúság . . . . . 57

Táblabiró . . . . 17 ti

Tabula rasa . . . 2 26

Tafel . . . . . . 333

Tagányi Károly . . . . . 146

Találós mese . . . . . . 16iti

Talleyrand . . . . . . it

Támadás . . . . . . .

Tánczszó . . . . . . 16:3

Tanúság . . . . . . . 1:34

Tanyás . . . . . 150

Telepedés . . . . . 111 i

Természeti sajátság. . . . 147

Természet, jellem . . . $14 \mathrm{~s}$

Thrák . . . . . 4 th

Thrákok . . . . 3:3

Tilalom . . . . . . 1!?

Timon Ákos könyve . . 19.

'Tisztelet . . . . . .3: 


\section{ast \\ Iin \\ 1141\%!}

timine

Inin

$1+1$

Iin

Hole Jonm

Uning

111.....

Iin $+w ! \cdot$ r

I1. - in the th

V.

Vhan in.

vali. tor. nin

Yenis yo Imoin

Yer thra
47

1. (f)

(i-t

ill;

1:3

- 111

I ili, I1!

!1

i

$5: 3$

i.

$17(1)$

178

$12 \%$

i):

1:3,

?

In ind

:. 1

$121)$

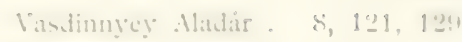

liata vezir.

11:

Vémil, hitji

2.

Vidimsig . . . . . . 5:1

lijucy. . . . . . . . . . . .

Jiginti Jizsef . . . . P(1)

Visclet . . . . . 17:\%

liti........ . . . . .

lizizion . . . . . . . . .

whit iynitst is

\ilu. . . . . . इ1

rnibirs

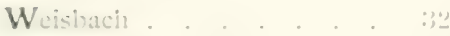

IVittmann . S

Zamaird falu. . . . . thi

timin it

7. I. in 1,

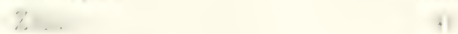

Zupor-Laki . . . . . 101 


\section{TARTAI. ()M.}

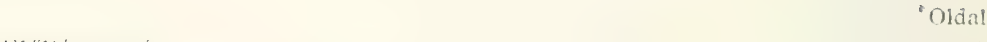

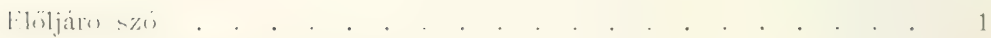

I. A MAGYAR NÉP ARC $/ A$. . . . . . . . . . . \&

Bovezetés . . . . . . . . . . . . . . . . . 11

A kiindúlás. . . . . . . . . . . . . . . . . 11

Mózses kiindúlása . . . . . . . . . . . . . . . . . . . . . . . . . 1 . .

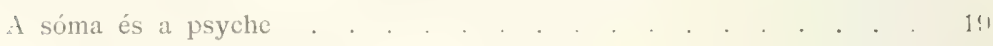

Anthropologiai vonatkozások . . . . . , . . . . . . . . 21

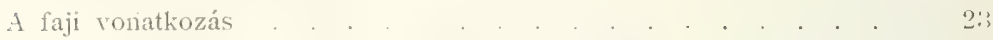

A faj és a valóság . . . . . . . . . . . . . . . ㄴ.

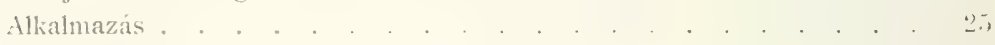

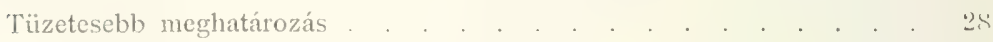

A heosztás. . . . . . . . . . . . . . . . . . 30

A fiziognomika is mimika. . . . . . . . . . . . . . . . :3:;

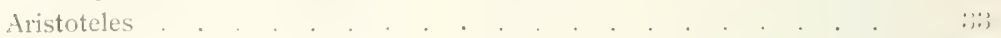

Schack . . . . . . . . . . . . . : .

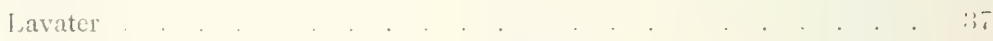

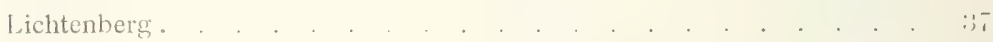

Gratiolet. . . . . . . . . . . . . . . . . . . . . . . . . . . . . . .

Darwin . . . . . . . . . . . . . . . . . . . . . . . . . . . . . . . .

Duchenne . . . . . . . . . . . . . . . . . 4 41

Piderit . . . . . . . . . . . . . . + + . .

Lombroso . . . . . . . . . . . . . . fli

Mantegazza. . . . . . . . . . . . . . . . . 4i

Fuesslin . . . . . . . . . . . . . . . . 4 4

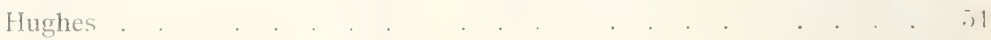

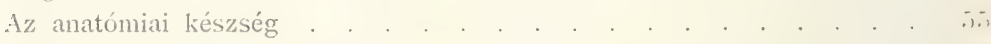

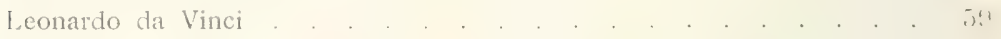

A szem . . . . . . . . . . . t tit

Kaulbach . . . . . . . . . . . . . . . . 1 . . . . .

Az оrr . . . . . . . . . . . . . . . lit

Arczok és arczulatok . . . . . . . . . . . . . . . . . 1i.

A mosoly . . . . . . . . . . . . . . . . . ti

Anevetés . . . . . . . . . . . . . t tis

1 kithatith. . . . . . . . . . . . . . 1is

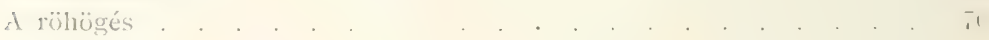


1 siris

Iz cidestiessez.

1 megretes

1 deszuilt tigyolem

A meglepeté:

A\% ijestelem

A harage

1) sszeurezés

Crakorlati alkalmazas

Sentt

Irinyi.

Beethosen

Deák.

Derhy

A gonoszternik hajzata .

1z arezhép az anthropolngition

A Peladat

A fiilveitel

A hivalasztás

1 meglevö anvarg.

Megkülönhöztetés.

it mridszer.

I hiha

Az igazi mamvarrk

ไàmléri.

Hunfalvy

inlf

A honfoulalis .

Régich maradványai .

Reinlariné .

Az átmenet.

Sapjaink magyarja:

1 tanusám. . . . . . . . . . . . . .

A kilicjtés

Az ös*zehasonlitís

Iamheri.

1z uri emher

Széchényi Istwin.

Kemeny \%sigmond

liezario szó.

III. FLCFIEI,EH

Esycztctess

Betürendes nér- és tarrymutato. 


\section{A Kir. Magyar Természettudományi Társulat kiadványaiból még a következők kaphatók.}

(A naglobb srimok a bolti arat jelentik, a kisebbek pedig a tagtarsainknak szóló kedvezményes arat abban az esetben, ha csak egy müvet visarolnak. Ino kor. bolti ani köny'vaisarlasinál a bolti arból $33 \%$ arleengedés szamittatik).

Abafi-Aigner, A leplészet története Magyarországon. $3-2$ kor. Bereczki, Gyümölcsészeti vázlatok, 4 kötethen, $20-16$ kor., kötre $24-20$ kor.

Brehm, Az északi sarktól az egyenlitöig; 37 rajz, 17 mülap $14-8$ kor.

Chemiai Folyóirat, 1895-1900, évfolyamonként 10-6 kor.

Chernel, Magyarorszáy madarai, két kötet, 40- szines mülappal, 16 táblával, 58 szöregrajzzal. 40-2+ kor. félbörkötésben 3 részben 6 koronával drágább.

Csopey-Kuppis, A világforgalom, 131 rajzzal, $7-6$ kor.

Czógler, A fizikai egyrégek, 4-3 kor.

Daday, A magyarországi Myriopodák magánrajza, 4 táblával. 4-3 kor. A magyar állattani irodalon ismertetése 1880-1890-ig. 4; kior.

Rovartani múszótár. Ára $1.40-1$ kor.

A magyarországi tarak halainak természetes táplálélia, 6-5 kor.

Darvai, Üstökösök, meteorok, 58 rajzzal. 3.20-2.60 kor.

Darwin, Az ember származása, 78 fametszettel, 2 lötet. $16-12$ kor.

De Candolle, Termesztett növényeink eredete, 64 képpel. $8-7$ kor.

Emery, A növények élete, 432 ábrával és mülappal. 16-12 kor.

Emlékkönyv a Természettudományi Társulat jubileumára, 155 rajz. $14-10$ kor.

Entz, Tanulmányok a réglények köréböl, I. kötet. 12-8 kor.

Felletár-Jahn, Törrényszéli chemia, $6-4$ kor.

Fílarszky, A charafélék, 20 ábra, 5 tábla rajzzal. 4-3 kor.

Francé, A Craspedomonadináli szervezete $4-3$ kor.

Freycinet, A természettudományi megismerés, 4-3 kor.

Gothard, A fotografia gyakorlatás alkalmazása, 40 rajzzal. 2.40-2 kor.

Graber, Az allitok mechanikai müszerci. 6-5 kor.

Grittner, Szénelemezések. 3-1.50 kor.

Guillemín, A mágnesség és clektromosság, 579 rajzzal. 14-12 kò. Hartmann, A majmok, 57 rajzzal. 4-3 kor. 


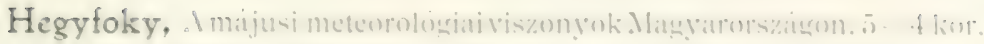

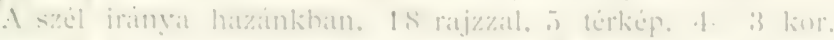

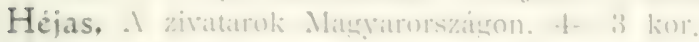

Heller, Az ilöjutis, 31 rajzanl. it- + hor.

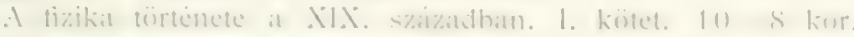

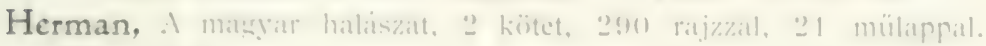
$2+$ lei kor.

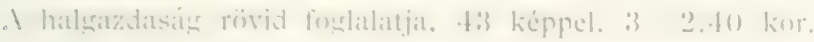

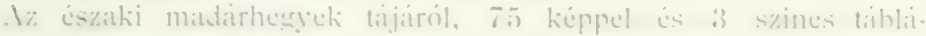
vill. 11)-_! ker.

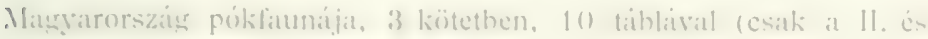
III. kötet kapható 12 koronacét $)$.

l'etenyi, a matgyar tud. madartan mesalapitrija, szines mülap. pal. 8 - b hor.

A matsyar ösfoglatlkozitsok köréhöl. dil rajz. "2 szines keppel. 1-().81) knr.

A matarak hasznairil es kirárol, 101) képpel, hekötre :)

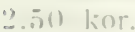

Houzeau, Acsillagriszat töménelmi jellemwonásat, is rajzzal. li is oh Ilosvay, A torjai hüdösbarlang. 2- 1 kor.

Inkey, Nagyas földtani és hányiszati viszonyai. 23 rajzzal, i- 4 kor. Jablonowski, A szölö betegriegei és ellenségei, 7 !) rajzzal. it 1 kor.

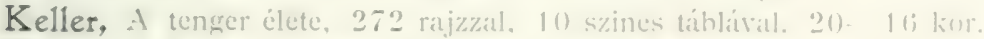
Kirándulók zsebkönvere, 70 rajzzal. 4- 3 kor.

Klug, Az ércékszervek élettanal, (9:3 rajzzal. 5-. + lior.

Kohaut, Maryarorszás szitakötöféléi, 3 taibla, 3- "2 hor.

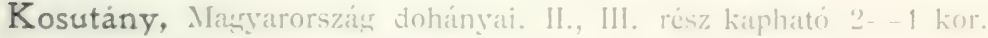
Linerarns Tabaksorten 1 kor.

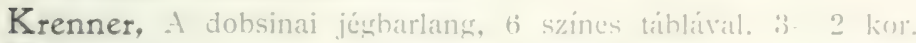

Krümmel, Az óczeán, fifi rajzzal, 4- 3 koj.

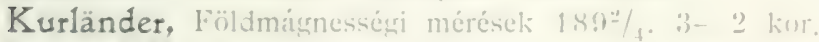

Lengyel B., A quantitatis chemiati analysis elemei, if- 1 kor.

Lengyel I., Tárırymutató à Természettudományi Közlïnyhöz. 2- 1 kor.

Lóczy, Khinat és népe, 200 rajzzal es térképpel. 20-16 kirr.

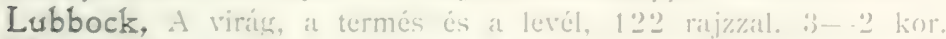

Magyar birodalom állatvilagának kitulógusit. Arthropodik. 3.5. 21) hor.

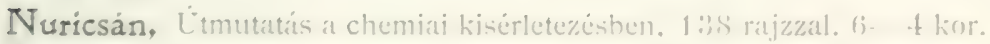

Petrovits, Homoli szölök telepitése és mivelese. Arat 4-2 kor.

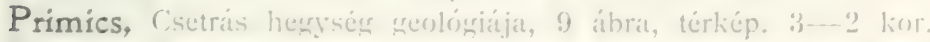

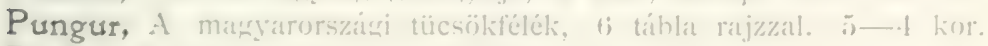

Reclus, A heurvele tiorténete, 18 keppel. 3 2.40 kor.

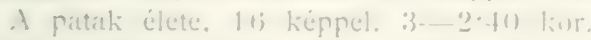

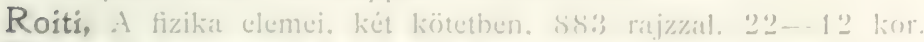

Róna, A lempromis a magyar hirodialomban. 4 - 3 lior.

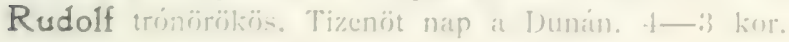


Schenzl, Nagrarország földmágnességi viszonyai. 18-14 kor.

Útmutatás földmágnességi helymeghatározásokra, 113 rajzzal. 4 -3 kor.

Schmidt, A drágakörek, 2 kötet. 53 rajzzal. 8-7 kor.

Schmidt F., A fotografozás gyakorlati kézikönyve. $6-5$ kor.

Simonyí, A sarkvidéki fölfedezések története, 51 rajzzal. 4.40-4 kor.

Stahlberger, Az írapály a fiumei öbölben, 8 táblával. 4-3 kor. Szabó, Elöadások a geológia köréböl, 201 képpel és mülapokkal. 7 - 6 kor.

Szádeczky, A zempléni szigethegység geológiája. 2.40-2 kor. .

Szilasi, Czukrok. Czukros anyagok megvizsgálása. $3-2$ kor.

Szinnyei, Természettud. és mathemat. könyrészet, 1472-tôl 1885-ig. 8 - i kor.

Természettudományi elöadások VII X. kötete, ;3 komáajaral.

Természettudományí Közlöny I., VI., IX., XII., XIV., XVI., XYII., XYII., XIX., XX., XXII, XXIY., XXY., XXVI., XXYII. XXIX., kötet 6-4 kor., Pótfüzetekkel 8-6 kor.

Than, A qualitativ chemiai analysis elemei. 6-4 kor.

Thanhoffer, Az ember anatómiája, 229 rajzzal és 10 táblával. 7 -6 kor. Tissié, Az elfáradás és a testgyakorlás. $6-\tilde{z}$ kor.

Ulbricht, Adatok a must-és borelemzés módszereihez. 2-1 kor. Vảngel, Allatok konzerválása gyújtemények számára 2-1 kor. Wartha, Az agyagárúkról 103 rajzzal és 25 mülappal. 6-5 kor.

\footnotetext{
Társulati rendes tag minden magyar állampolgár lehet, ki a természettudományok iránt érdeklödik s a kit egy társulati tag ajani. - Az évi tagdij vidéken 6 kor.. Budapesten 10 hor.. a mely összegért a Természettudományi Közlöny évi folyama jár, - Tagsági levél 4 kor. - A Pótfüzet dija ə kor. - A Társulat éve januárral kezdödik; az ểközben belépỏ tagok tehát megkapják a Társulat folyóiratának egẻsz évi füzeteit. - Választás van minden hónap harmadik szerdáján.
} 



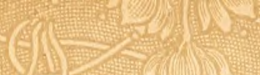

,

(2)

(6)

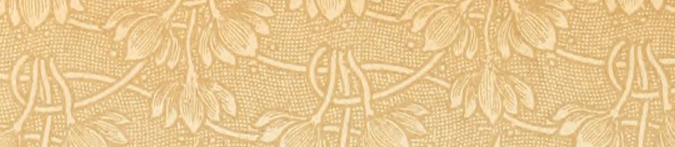

GA

(9)

6)

$A>-2$

(6) -.

$\frac{15}{4}$ (n) (9) 9. (9)

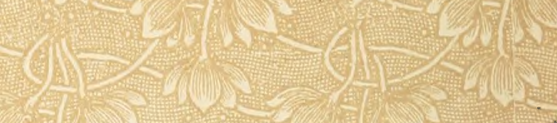
sein

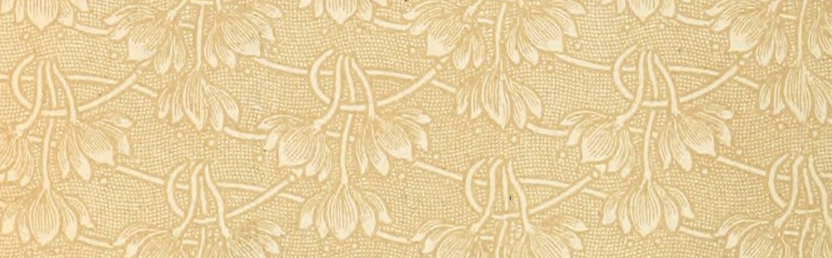
$\theta=$
(A)
(a)
$(9)$

$=\left(\frac{5}{5}\right)$

$-6)^{2}$

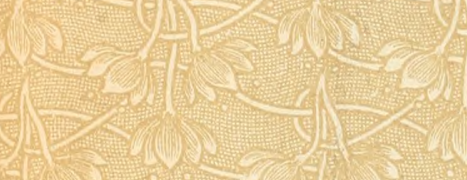

(6)

$(6)$

(3)

(a)

(a)

$($ a)

$(5)$

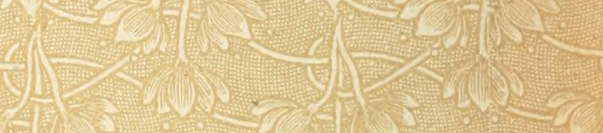
(9)

(c)

AP

(f)

$(4)$

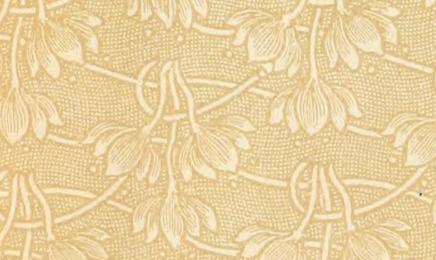

a)

(1)

enters)

(:ㅏㅇㅛ

$(5)$

$\left(\frac{6}{2}\right)$

$\left(\frac{1}{4}\right.$

$(-5)$

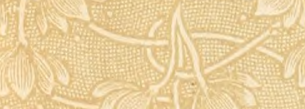

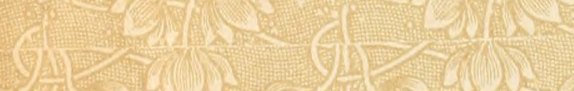

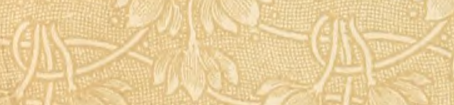

(I)

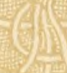

$(9)$

(6)

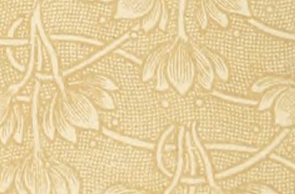

(ㄷ.

$x^{2}$

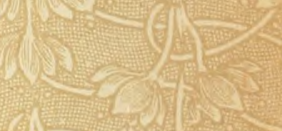




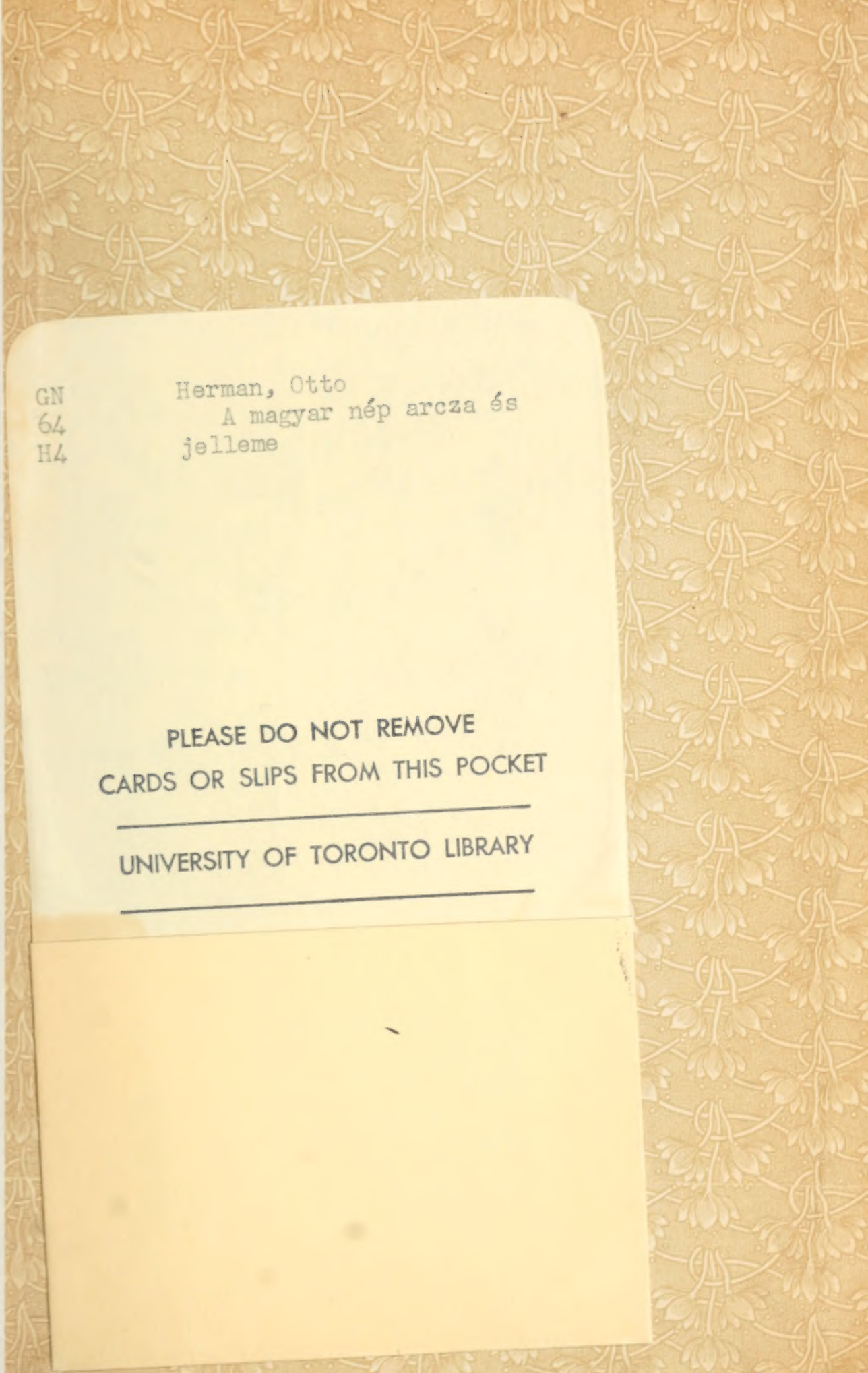




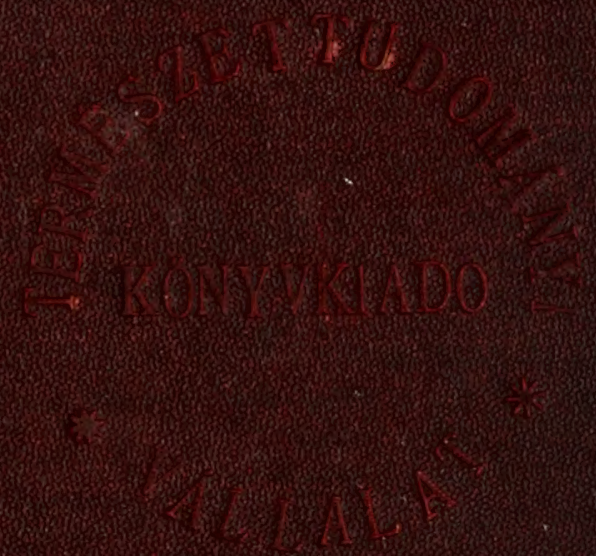

